LOCKHEED MATTIN

ENVIRONMENTAL RESTORATION PROGRAM

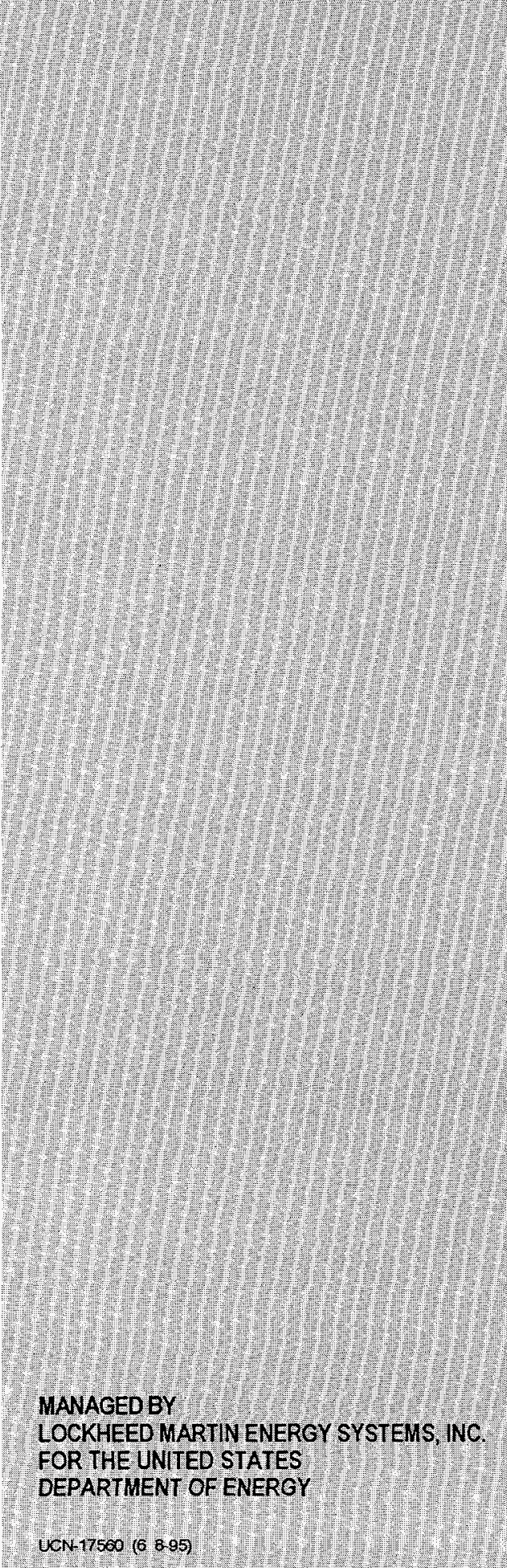

\section{Nuclear Criticality Safety Calculations for a K-25 Site Vacuum Cleaner}

\author{
RECEIVED \\ APR 181997 \\ OSTI
}

K/ER-314 


\section{DISCLAIMER}

This report was prepared as an account of work sponsored by an agency of the United States Government. Neither the United States Government nor any agency thereof, nor any of their employees, makes any warranty, express or implied, or assumes any legal liability or responsibility for the accuracy, completeness, or usefulness of any information, apparatus, product, or process disclosed, or represents that its use would not infringe privately owned rights. Reference herein to any specific commercial product, process, or service by trade name, trademark, manufacturer, or otherwise does not necessarily constitute or imply its endorsement, recommendation, or favoring by the United States Government or any agency thereof. The views and opinions of authors expressed herein do not necessarily state or reflect those of the United States Government or any agency thereof. 


\section{DISCLAIMER}

Portions of this document may be illegible electronic image products. Images are produced from the best available original document. 
Energy Systems Environmental Restoration Program

\title{
Nuclear Criticality Safety Calculations for a K-25 Site Vacuum Cleaner
}

\author{
J. T. Shor \\ M. J. Haire
}

Date Issued-February 1997

\author{
Prepared by \\ Chemical Technology Division \\ Oak Ridge National Laboratory \\ Oak Ridge, Tennessee \\ Prepared for the \\ U.S. Department of Energy \\ Office of Environmental Management \\ under budget and reporting code EW 20 \\ Environmental Management Activities at the \\ OAK RIDGE K-25 SITE \\ Oak Ridge, Tennessee 37831 \\ managed by \\ LOCKHEED MARTIN ENERGY SYSTEMS, INC. \\ for the \\ U.S. DEPARTMENT OF ENERGY \\ under contract DE-AC05-84OR21400
}




\section{PREFACE}

A modified Nilfisk Model GSJ-115 dry vacuum cleaner is used throughout the K-25 Site for cleanup of dry forms of highly enriched uranium (HEU). This report describes the calculations done with the SCALE (KENO V.a) computer code to establish the minimum nuclear critical mass for this vacuum cleaner. This report does not represent a complete nuclear criticality safety evaluation. Such an evaluation, of which this report may be a supporting document, is contained in K-25 Site Nuclear Criticality Safety Evaluations.

This work was performed under Work Breakdown Structure 1.4.12.4.2.01.46 (Activity Sheet 4701).

Reference herein to any specific commercial product, process, or service by trade name, trademark, manufacturer, or otherwise, does not necessarily constitute or imply its endorsement, recommendation, or favoring by the United States Government or any agency thereof. The views and opinions of authors expressed herein do not necessarily state or reflect those of the United States Government or any agency thereof. 
-

-

- 


\section{CONTENTS}

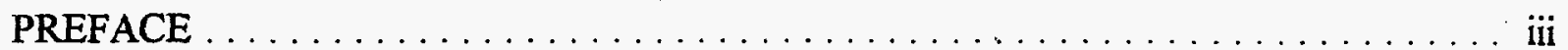

LIST OF FIGURES $\ldots \ldots \ldots \ldots \ldots \ldots \ldots \ldots \ldots \ldots \ldots \ldots \ldots \ldots$ vii

LIST OF TABLES $\ldots \ldots \ldots \ldots \ldots \ldots \ldots \ldots \ldots \ldots \ldots \ldots \ldots \ldots \ldots$

ACRONYMS AND ABBREVIATIONS $\ldots \ldots \ldots \ldots \ldots \ldots \ldots \ldots \ldots \ldots$ ix

EXECUTIVE SUMMARY $\ldots \ldots \ldots \ldots \ldots \ldots \ldots \ldots \ldots \ldots \ldots \ldots \ldots \ldots \ldots$

1. INTRODUCTION $\ldots \ldots \ldots \ldots \ldots \ldots \ldots \ldots \ldots \ldots \ldots \ldots \ldots \ldots$

2. VACUUM CLEANER DESCRIPTION $\ldots \ldots \ldots \ldots \ldots \ldots \ldots \ldots \ldots \ldots \ldots$

2.1 VACUUM CLEANER BODY $\ldots \ldots \ldots \ldots \ldots \ldots \ldots \ldots \ldots \ldots \ldots$

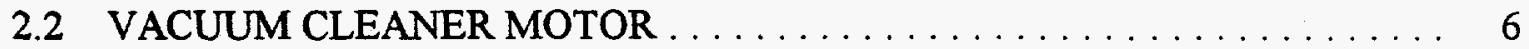

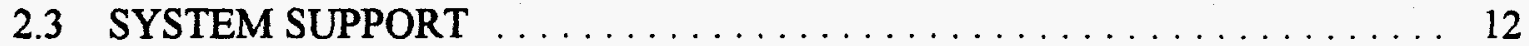

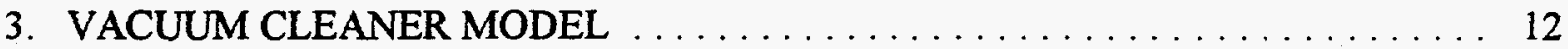

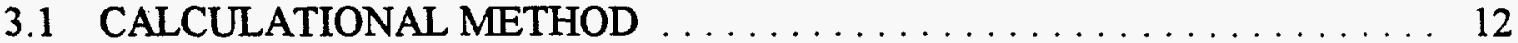

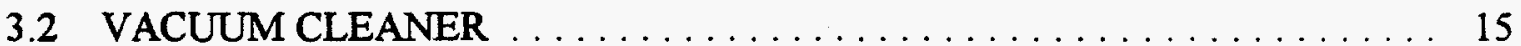

3.2.1 Vacuum Cleaner Body Geometry . . . . . . . . . . . . . . . 15

3.2.2 Vacuum Cleaner Motor Geometry and Materials . . . . . . . . . . . . 30

3.3 BASELINE MODEL . . . . . . . . . . . . . . . . . . . . . . . 33

3.4 DIFFERENCES BETWEEN CURRENT AND EARLIER MODELS $\ldots \ldots \ldots 34$

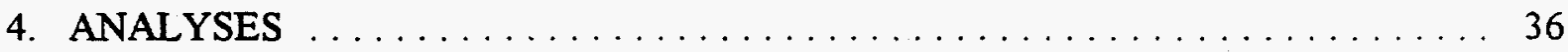

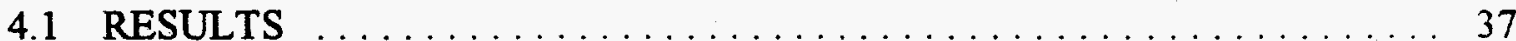

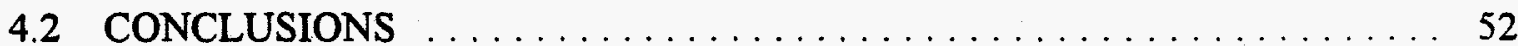

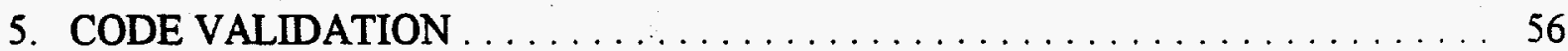

6. REFERENCES $\ldots \ldots \ldots \ldots \ldots \ldots \ldots \ldots \ldots \ldots \ldots \ldots \ldots \ldots \ldots \ldots \ldots$

APPENDIX A. MODELING CALCULATIONS $\ldots \ldots \ldots \ldots \ldots \ldots \ldots \ldots$

APPENDIX B. CRITICALITY SAFETY CALCULATION CHECK-OFF SHEET . . . B-1 
APPENDIX C. KENO-CODE-GENERATED MAP OF VACUUM CLEANER

$\mathrm{C}-1$

APPENDIX D. VOLUMES OF UNITS 1 THROUGH 18, CALCULATED BY

EXCEL AND KENO

D-1

APPENDIX E. MATH CAD ESTIMATES OF ACTUAL VACUUM CLEANER MINIMUM VOLUME

APPENDIX F. SAMPLE OF SCALE OUTPUT CASE 1, $70 \mathrm{~g} \mathrm{U} / \mathrm{L}, 12$-in. water REFLECTION F-1 


\section{LIST OF FIGURES}

Fig. Es. 1 Critical uranium concentrations as a function of enrichment for baseline materials, Case 1,12 -in. water reflection $\ldots \ldots \ldots \ldots \ldots \ldots \ldots \ldots \ldots$ xvi

Fig. $1 \quad \mathrm{~K}-25$ Site portable dry HEU vacuum cleaner $\ldots \ldots \ldots \ldots \ldots \ldots$

Fig. 2 Schematic of $\mathrm{K}-25$ Site portable dry vacuum cleaner $\ldots \ldots \ldots \ldots$

Fig. $3 \quad$ Cyclone body $\ldots \ldots \ldots \ldots \ldots \ldots \ldots \ldots \ldots \ldots \ldots \ldots \ldots$

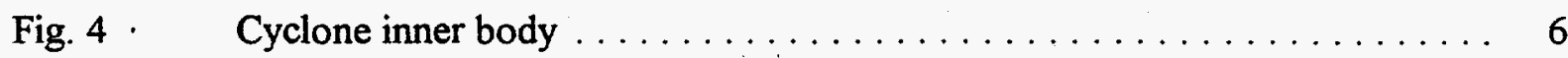

Fig. $5 \quad$ Filter retainer $\ldots \ldots \ldots \ldots \ldots \ldots \ldots \ldots \ldots \ldots \ldots \ldots \ldots \ldots$

Fig. $6 \quad$ Vacuum cleaner funnel $\ldots \ldots \ldots \ldots \ldots \ldots \ldots \ldots \ldots \ldots \ldots \ldots \ldots$

Fig. 7 Division of vacuum cleaner into cylindrical sections for modeling $\ldots \ldots \ldots 16$

Fig. $8 \quad$ Units 1 and 2: plastic bottle and connecting fitting $\ldots \ldots \ldots \ldots$

Fig. 9 Cone and frustum model of Units $3-6 \ldots \ldots \ldots \ldots$

Fig. 10 Schematic of model and actual frustum, bottom of cyclone $\ldots \ldots \ldots 19$

Fig. 11 Unit 7 : cyclone straight section $\ldots \ldots \ldots \ldots \ldots \ldots \ldots \ldots$

Fig. 12 Units 8 and 9: model of cyclone inner body frustum $\ldots \ldots \ldots 22$

Fig. 13 Model of Units 10-13: upper frustum of cyclone inner body $\ldots \ldots \ldots 23$

Fig. 14 Schematic of model and actual part, upper frustum of cyclone inner body . . 24

Fig. 15 Model of Units 14, 15, 16, and 17: flange section and motor assembly . . . 26

Fig. $16 \quad$ Model of Unit 15: motor base assembly $\ldots \ldots \ldots \ldots \ldots \ldots$

Fig. $17 \quad$ Model of Units 16 and 17: motor assembly $\ldots \ldots \ldots \ldots \ldots$

Fig. $18 \quad$ Unit 18: HEPA filter and casing $\ldots \ldots \ldots \ldots \ldots \ldots \ldots \ldots \ldots$ 
Fig. 19 Schematic of actual motor assembly approximate dimensions $\ldots \ldots \ldots . \ldots 31$

Fig. 20 Schematic of actual motor assembly materials based on Nilfisk parts . . . . 32

Fig. $21 \quad$ Case 1, 12-in. reflection, $100 \%$ iron motor parts $\ldots \ldots \ldots \ldots \ldots \ldots$

Fig. 22 Case 1, 1-in. reflection, $100 \%$ iron motor parts $\ldots \ldots \ldots \ldots \ldots \ldots$

Fig. 23 Case 2,12 -in. reflection, $100 \%$ copper motor parts $\ldots \ldots \ldots \ldots \ldots 41$

Fig. 24 Case 2, 1-in. reflection, $100 \%$ copper motor parts $\ldots \ldots \ldots \ldots \ldots \ldots 42$

Fig. 25 Case 3, 12 -in. reflection, $50 \%$ copper $/ 50 \%$ iron motor parts $\ldots \ldots \ldots . \ldots 4$

Fig. 26 Case 3,1 -in. reflection, $50 \%$ copper $/ 50 \%$ iron motor parts $\ldots \ldots \ldots .45$

Fig. 27 Case 4, 12-in. reflection, motor parts replaced with fissile solution $\ldots \ldots 47$

Fig. 28 Case 4, 1-in. reflection, motor parts replaced with fissile solution $\ldots \ldots \ldots 48$

Fig. $29 \quad K_{\text {eff }}$ Case 1 vs number of generations, 300 neutrons per generation ..... 50

Fig. 30 Standard deviation vs number of generations, Case 1, 300 neutrons per

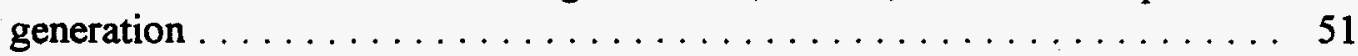

Fig. $31 \quad K_{e f f}$ vs total $\mathrm{U} g / \mathrm{L}, 20 \%{ }^{235} \mathrm{U}, 12$-in. reflection $\ldots \ldots \ldots \ldots \ldots \ldots \ldots$

Fig. 32 Baseline Case 1 calculations of $k_{\text {eff }}$ vs uranium concentration 1 -in. and

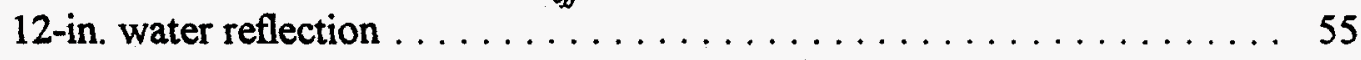

Fig. 33 Comparison of validated and PC $k_{\text {eff }}$ results (error bars represent

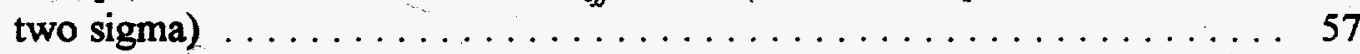

Fig. C.1 KENO-code-generated map of vacuum cleaner $\ldots \ldots \ldots \ldots \ldots \ldots \ldots$ C-3

Fig. E.1 Explanation of mathcad volume estimate $\ldots \ldots \ldots \ldots \ldots \ldots \ldots$ E-3 


\section{LIST OF TABLES}

Table Es. 1 Calculations at critical conditions for $100 \%$ enrichment $\ldots \ldots \ldots \ldots$ xv

Table $1 \quad$ Motor features and specifications $\ldots \ldots \ldots \ldots \ldots \ldots \ldots \ldots \ldots$

Table 2 Motors parts-GSJ $\ldots \ldots \ldots \ldots \ldots \ldots \ldots \ldots \ldots \ldots \ldots \ldots \ldots \ldots$

Table 3 Composition of motor parts modeled in four cases $\ldots \ldots \ldots \ldots \ldots . \ldots 34$

Table $4 \quad$ Baseline case results: $100 \%$ iron motor parts $\ldots \ldots \ldots \ldots \ldots \ldots \ldots$

Table $5 \quad$ Case $2,100 \%$ copper motor parts $\ldots \ldots \ldots \ldots \ldots \ldots \ldots \ldots \ldots$

Table 6 Case $3,50 \%$ copper $/ 50 \%$ iron motor parts $\ldots \ldots \ldots \ldots \ldots \ldots \ldots$

Table 7 Case 4, all motor parts are replaced with fissile solution $\ldots \ldots \ldots \ldots$

Table $8 \quad K_{\text {eff }}$ vs total uranium concentration, $20 \%$ enrichment $\ldots \ldots \ldots \ldots \ldots 4$

Table 9 Comparison of validated and PC $k_{e f f}$ results $\ldots \ldots \ldots \ldots \ldots \ldots$

Table D.1 Calculated volumes of individual units of model of vacuum cleaner . . . . D-3 


\title{
ACRONYMS AND ABBREVIATIONS
}

\author{
DR Deposit removal \\ HEU Highly enriched uranium \\ PVC Polyvinylchloride \\ SCALE Standardized Computer Analysis for Licensing Evaluation
}




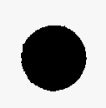

○
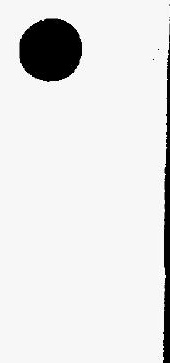


\section{EXECUTIVE SUMMARY}

A modified Nilfisk model GSJ dry vacuum cleaner is used throughout the K-25 Site to collect dry forms of highly enriched uranium (HEU). When vacuuming, solids are collected in a cyclone-type separator vacuum cleaner body. The cyclone drops particulates into a receptacle (a deposit bottle) that is screwed onto the bottom of the cyclone separator. Exhaust air from the portable vacuum cleaner is subjected to a three-stage filtration system-a prefilter and two cylindrical HEPA filters. As necessary, the receptacle and vacuum cleaner cyclone are disconnected for cleaning, and the product removed and sent to storage.

Calculations were done with the SCALE (KENO V.a) computer code to establish conditions at which a nuclear criticality event might occur if the vacuum cleaner was filled with fissile solution. Conditions evaluated included full (12-in. water) reflection and nominal (1-in. water) reflection, and full (100\%) and $20 \%{ }^{235} \mathrm{U}$ enrichment. Validation analyses of SCALE/KENO and the SCALE 27-group cross sections for nuclear criticality safety applications indicate that a calculated $k_{e f f}+2 \sigma<0.9605$ may be considered safely subcritical. Thus, a system with a calculated $k_{e f f}+2 \sigma \geq 0.9605$ is considered unsafe and may be critical. The upper-bound uranium-fissile mass was calculated with an additional factor of safety of 0.01 corresponding to an acceptable criterium of $k_{\text {eff }}+2 \sigma<0.95$.

Critical conditions were calculated to be $70 \mathrm{~g} \mathrm{U} / \mathrm{L}$ for $100 \%{ }^{235} \mathrm{U}$ and full 12 -in. water reflection. This corresponds to a minimum critical mass of approximately $1400 \mathrm{~g}^{235} \mathrm{U}$ for the approximate $20.0-\mathrm{L}$ volume of the vacuum cleaner. The actual volume of the vacuum cleaner is smaller than the modeled volume because some internal materials of construction were assumed to be fissile solution. The model was an overestimate, for conservatism, of fissile solution occupancy. At nominal (1-in. water) reflection conditions, the critical concentration in a vacuum cleaner full of $\mathrm{UO}_{2} \mathrm{~F}_{2}$ solution was calculated to be $100 \mathrm{~g}^{235} \mathrm{U} / \mathrm{L}$, or $2000 \mathrm{~g}$ mass of $100 \%{ }^{235} \mathrm{U}$. At $20 \%{ }^{235} \mathrm{U}$ enrichment, full 12 -in. water reflection and baseline materials, critical conditions were calculated to be $700 \mathrm{~g}$ total $\mathrm{U} / \mathrm{L}$. This corresponds to a minimum critical mass of $2800 \mathrm{~g}^{235} \mathrm{U}$ for the $20.0-\mathrm{L}$ volume of the vacuum cleaner. At $15 \%{ }^{235} \mathrm{U}$ enrichment and full reflection, critical conditions were not reached at any possible 
concentration of uranium as a uranyl fluoride solution. At $17.5 \%{ }^{235} \mathrm{U}$ enrichment, criticality was reached at approximately $1300 \mathrm{~g} \mathrm{U} / \mathrm{L}$ which is beyond saturation at $25^{\circ} \mathrm{C}$.

The vacuum cleaner geometry is well known and was accurately, though conservatively, modeled. The distribution of the materials of composition in the vacuum cleaner motor is not as well known so sensitivity studies were performed. These sensitivity studies showed that the material of composition has, at most, a $0.17 \%$ effect on $k$-effective at 12 -in. water reflection and $70 \mathrm{~g}{ }^{235} \mathrm{U} / \mathrm{L}$, well within $2 \sigma$ variation. Results are summarized in Table Es.1. Calculations were performed to determine the concentrations at which criticality is possible at 12-in. water reflections and base-case assumptions. These results are shown in Fig. Es. 1. 
Table Es. 1. Calculations at critical conditions for $100 \%$ enrichment

\begin{tabular}{|c|c|c|c|c|c|c|c|c|c|c|}
\hline \multicolumn{9}{|c|}{ Motor parts } & \multirow{3}{*}{ Concentration } & \multirow{3}{*}{ Reflection } \\
\hline \multicolumn{3}{|c|}{$\begin{array}{c}\text { Baseline, Case } 1 \\
(100 \% \text { iron })\end{array}$} & \multicolumn{3}{|c|}{$\begin{array}{c}\text { Case } 2 \\
(100 \% \text { copper })\end{array}$} & \multicolumn{3}{|c|}{$\begin{array}{c}\text { Case } 3 \\
\text { (50\% copper } / 50 \% \text { iron) }\end{array}$} & & \\
\hline$k_{\text {eff }}$ & $2 \sigma$ & $k_{e f f}+2 \sigma$ & $\boldsymbol{k}_{\text {eff }}$ & $2 \sigma$ & $k_{e f f}+2 \sigma$ & $k_{\text {eff }}$ & $2 \sigma$ & $k_{e f f}+2 \sigma$ & & \\
\hline 0.9314 & 0.0094 & 0.9408 & 0.9310 & 0.011 & 0.942 & 0.9294 & 0.0096 & 0.9386 & $70 \mathrm{~g} \mathrm{U} / \mathrm{L}$ & 12 in. \\
\hline 0.9332 & 0.0108 & 0.944 & 0.9176 & 0.0116 & 0.9292 & 0.9176 & 0.0112 & 0.9288 & $100 \mathrm{~g} \mathrm{U} / \mathrm{L}$ & 1 in. \\
\hline
\end{tabular}




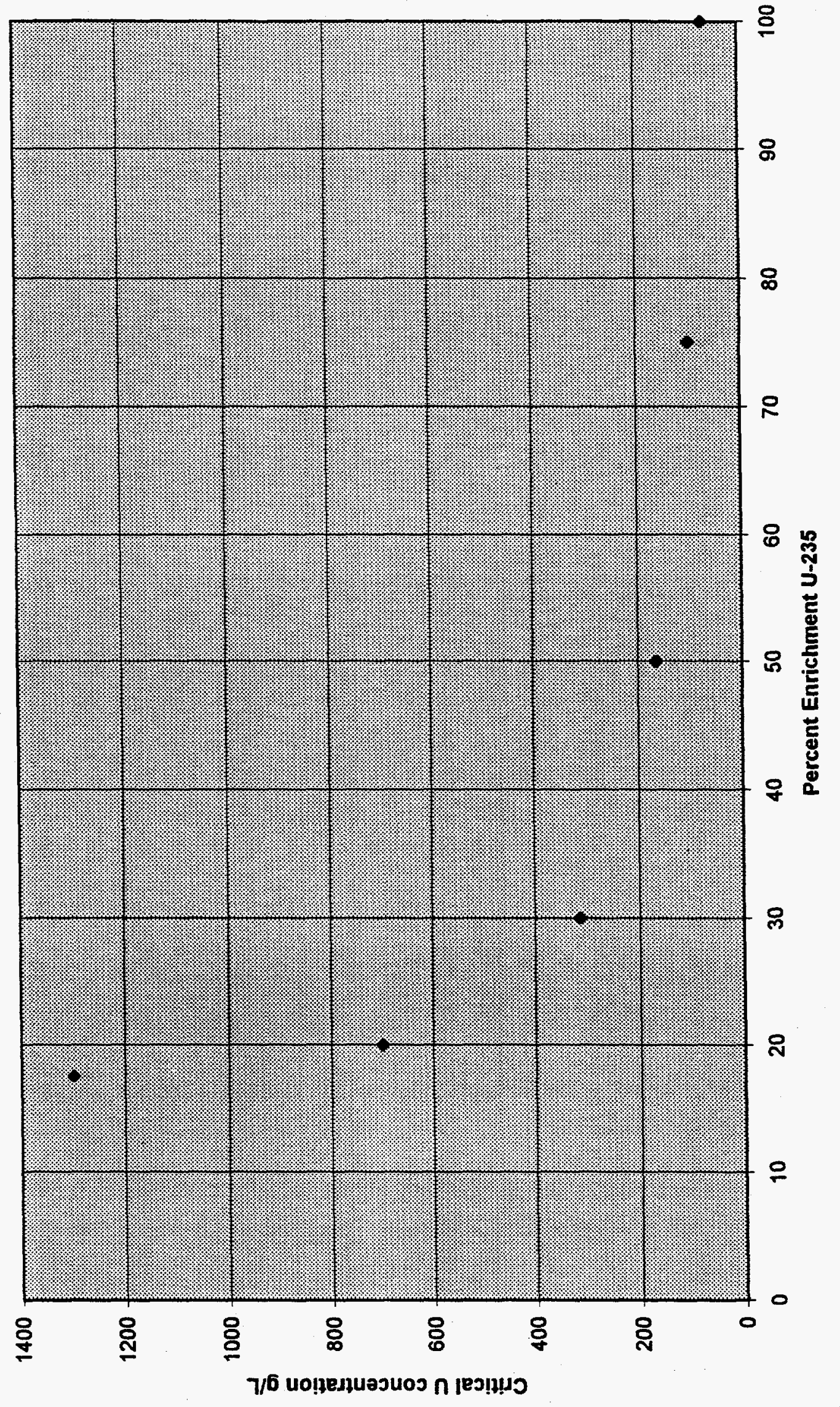

בั๋

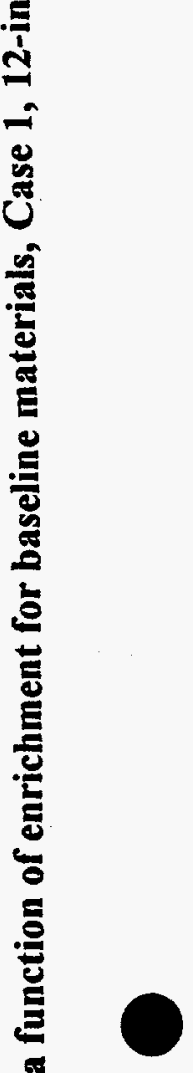




\section{INTRODUCTION}

A modified Nilfisk model GSJ dry vacuum cleaner is used throughout the K-25 Site for cleanup of dry forms of highly enriched uranium (HEU). Figure 1 presents a photograph of the vacuum cleaner mounted on a trolley; the vacuum cleaner might also be mounted in a fixed geometry, such as in a glove box. Figure 2 gives important dimensions of the trolleymounted vacuum cleaner. Vacuum cleaner motors were purchased from Nilfisk of America, Inc., and attached to a vacuum cleaner body fabricated by Machine Kinetics Corp. of Knoxville, Tennessee, to K-25 Site specifications. When vacuuming, solids are collected in a cyclone-type separator, the body. The cyclone drops particulates consisting of uranium and other materials into a deposit bottle that is screwed onto the bottom of the cyclone separator. Exhaust air from the portable vacuum cleaner is subjected to a three-stage filtration system: a prefilter and two cylindrical HEPA filters. As necessary, the deposit bottle and vacuum cleaner cyclone are disconnected for cleaning, and the product removed and sent to storage.

This report describes calculations done with the SCALE (KENO V.a) ${ }^{1}$ computer code to establish conditions for a nuclear criticality event. Nuclear criticality conditions were calculated with full (12-in. water) reflection and nominal (1-in. water) reflection and for full $(100 \%)$ and $20 \%{ }^{235} \mathrm{U}$ enrichment with full reflection. An iterative approach was used to establish the uranium mass at critical conditions. Collection of liquids with the vacuum cleaner is prohibited. However, assuming the vacuum cleaner is full of liquid, calculations were begun at low concentrations of uranium in solution, and then, the concentration increased until critical conditions were reached. The mass of uranium in the vacuum cleaner was then calculated by multiplying the highest concentration with $k_{e f f}+2 \sigma<0.95$, by the vacuum cleaner volume.

This vacuum cleaner is used throughout the K-25 Site for collecting dry forms of compounds of uranium in the powder form or small chunks. Thus, a nuclear criticality safety analysis is required for each use. This report presents a calculational criticality analysis of the vacuum cleaner. It does not represent a complete criticality safety evaluation and does not constitute nuclear criticality safety approval for operation. However, this report may be 




L9GG-E6 Hd/X ON OLOHd 


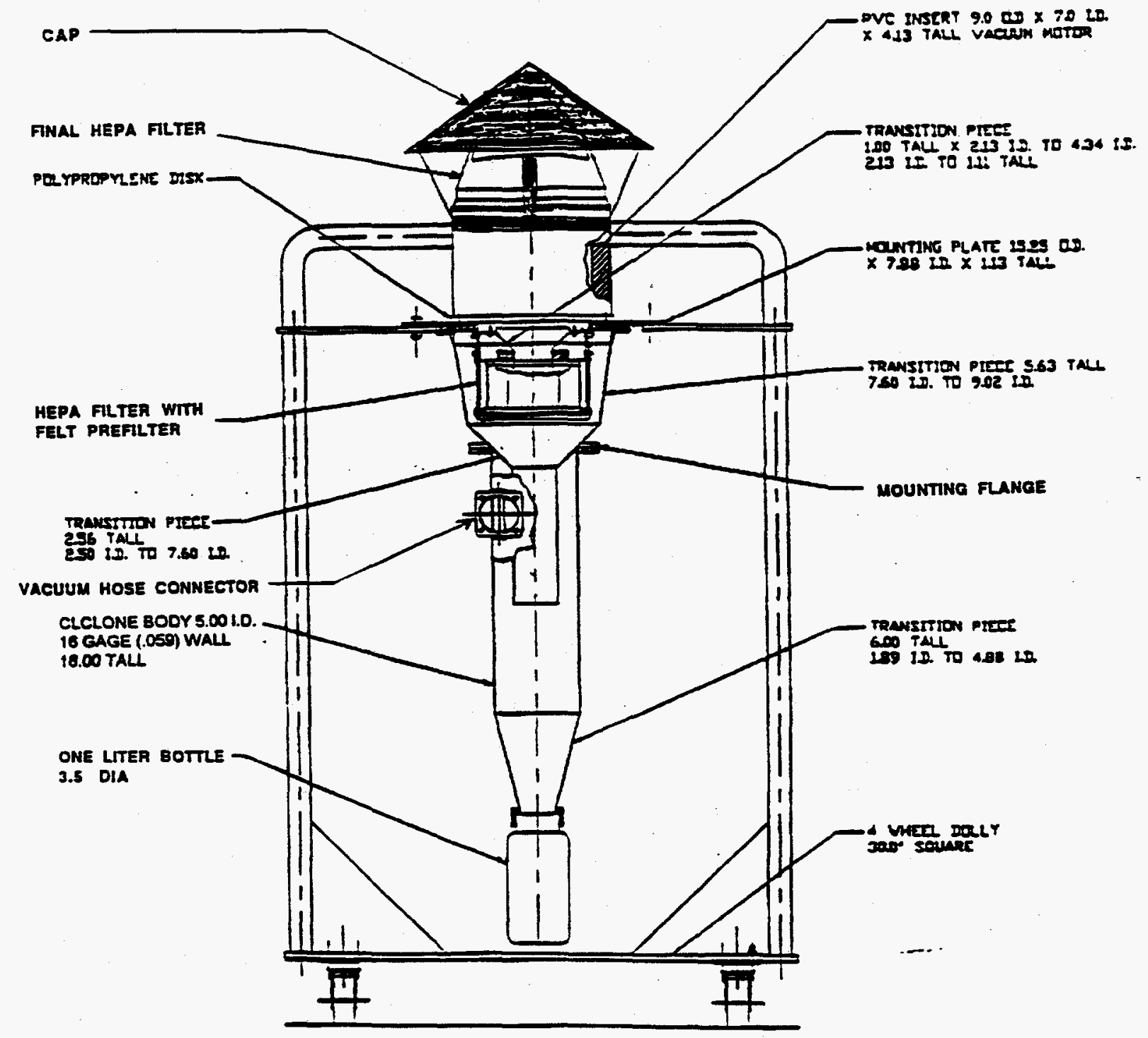

-ALL DIMENSIONS IN INCHES-

Fig 2. Schematic of K-25 Site portable dry vacuum cleaner. 
used to support a complete evaluation. Such an evaluation, and conditions of approval for operation, are given in K-25 Site Nuclear Criticality Safety Approvals. This report gives calculated reactivity or neutron multiplication factors of the vacuum cleaner for specific conditions of uranium loading (mass), ${ }^{235} \mathrm{U}$ enrichment, moderation levels, and reflection. No attempt is made to specify the safe enrichment or conditions of operations (and related control parameters) for the system.

\section{VACUUM CLEANER DESCRIPTION}

A modified Nilfisk model GSJ dry vacuum cleaner is used to clean up dry forms of highly enriched uranium (HEU) at the K-25 Site. Figure 1 presents a photograph of the portable vacuum cleaner. The body (a cyclone-type separator) of the vacuum cleaner was fabricated by Machine Kinetics Corp. of Knoxville, Tennessee, to K-25 Site specifications. The body is attached to a motor, model number GSJ-115, purchased from Nilfisk of America, Inc. K-25 Site drawings M1E703045 A021 through A027 give complete dimensions and a description for the fixed vacuum cleaner used in the Deposit Removal (DR) Program's DR Room glove box. The body of the portable and fixed vacuum cleaners are identical. Figure 2 gives important general dimensions.

\subsection{VACUUM CLEANER BODY}

The vacuum cleaner uses a standard approximately 1.5-in.-diam dry vacuum hose and optional attachments. Solids are collected in a cyclone-type separator which is primarily a cylinder 5.0 in. outside diam. Figure 3 shows detailed dimensions of the cyclone separator. The material of construction is 304 stainless steel (SS). The cyclone drops particulates into a deposit bottle that is screwed into the bottom of the cyclone. The 1-L polypropylene deposit bottle dimensions are approximately $3.5 \mathrm{in}$. diam and 8 in. high. The vacuum cleaner hose mounts at the side of the cylindrical vacuum cleaner body so that the tangential inlet air creates a centrifugal, cyclone effect. Gravity causes the collected particulates to drop into the deposit bottle at the bottom. 


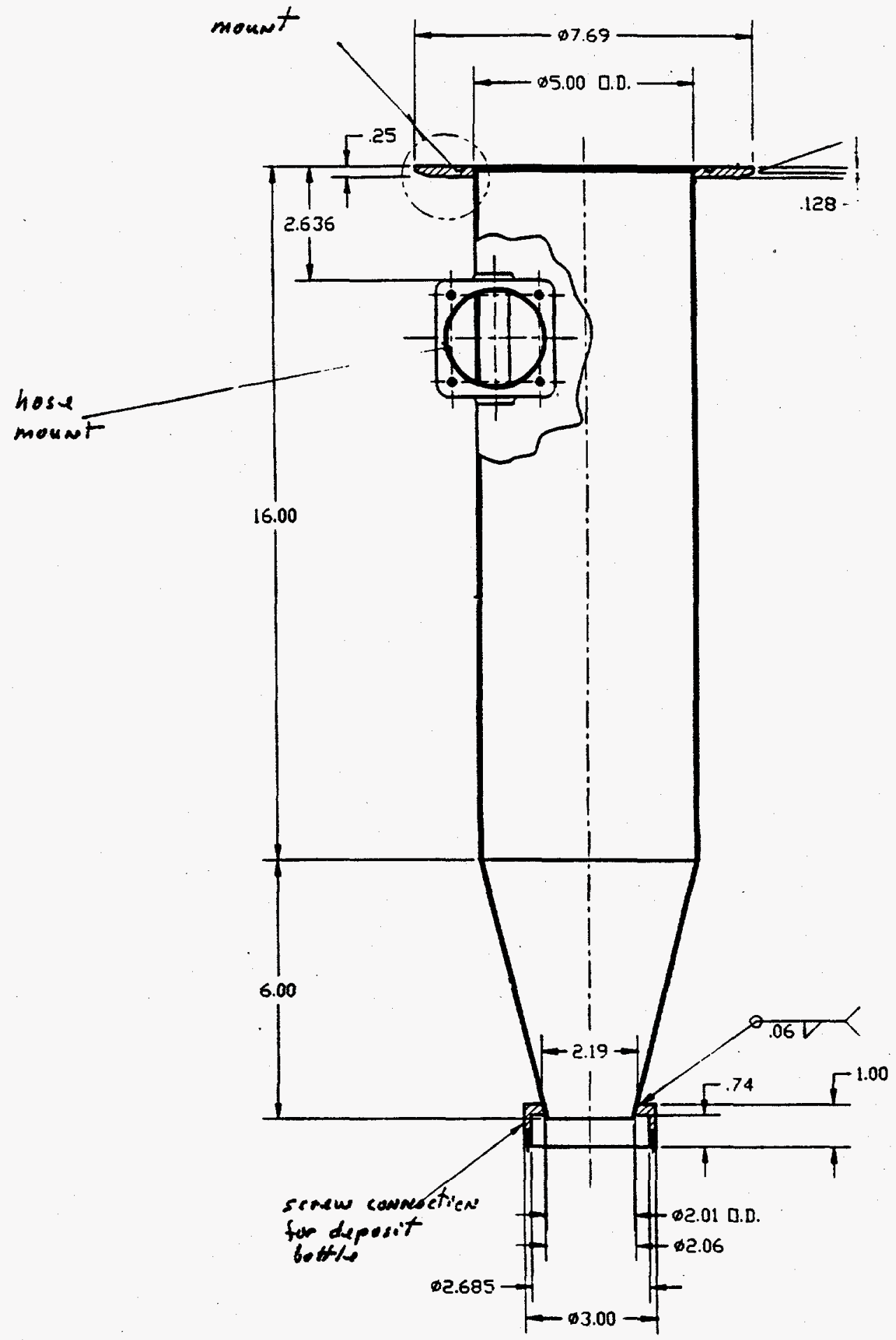

Fig. 3. Cyclone body. 
The cyclone inner body is fixed atop the cyclone body by placing the mounting flange shown in Fig. 4 onto the mount shown in Fig. 3. Note that the vacuum cleaner inlet (downcomer) is below the hose inlet to keep from sucking dust and particulates directly onto the system filters. The cyclone body is removable from the inner body which facilitates cleaning the interior metal surfaces.

The filter retainer (see Fig. 5) is mounted on top of the cyclone inner body. A cylindrical HEPA filter, purchased from Nilfisk, slides inside the filter retainer. The HEPA filter is approximately 5-1/2 in. diam and 3 in. high with a filter area of $3721 \mathrm{~cm}^{2}$. A Nilfisk microfilter, felt "sock" prefilter surrounds the HEPA filter. This prefilter typically retains $99.97 \%$ (ref. 2) of all particles down to $2 \mu \mathrm{m}$ size, protecting the motor and filtering out many respirable particles.

The air funnel to the vacuum cleaner (shown in Fig. 6) attaches to the base plate and directs air into the vacuum cleaner motor. The vacuum cleaner motor and surrounding casing are mounted to the base plate.

\subsection{VACUUM CLEANER MOTOR}

The vacuum cleaner motor is Nilfisk model number GSJ-115. Tables 1 and 2 were supplied by Nilfisk of American, Inc., ${ }^{3}$ which gives the motor features and an exploded view of various parts. In Table 2 , the motor top and casing is primarily plastic; the fan is primarily aluminum; the motor is primarily aluminum with some steel; and the armature and field coil are primarily copper and steel. Nilfisk staff supplied the following weights:

$\begin{array}{lll}\text { armature } & 1.25 \mathrm{lbs} & \text { copper and steel } \\ \text { field coil } & 2 \mathrm{lbs} & \text { copper and steel } \\ \text { fan assembly } & 1.25 \mathrm{lbs} & \text { aluminum } \\ \text { motor assembly } & 2.25 \mathrm{lbs} & \text { aluminum and steel }\end{array}$

ORNL staff weighed the motor to be $8.25 \mathrm{lbs}$ total. The difference between this total weight and the weights supplied by Nilfisk staff is taken as the weight of the plastic casing. The plastic casing was modeled as $\mathrm{UO}_{2} \mathrm{~F}_{2}$ solution for conservatism. This baseline analysis 


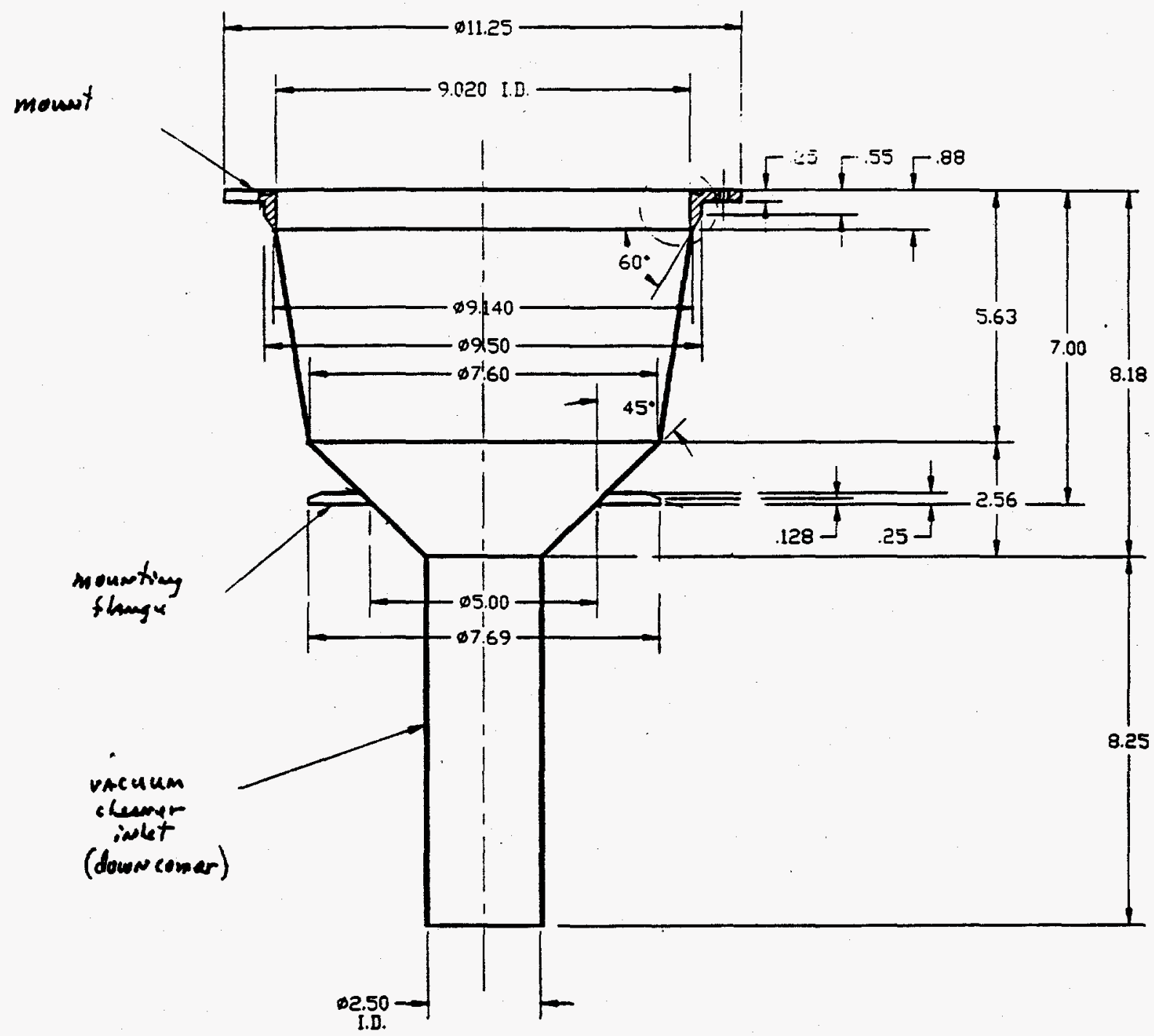

Fig. 4. Cyclone inner body. 


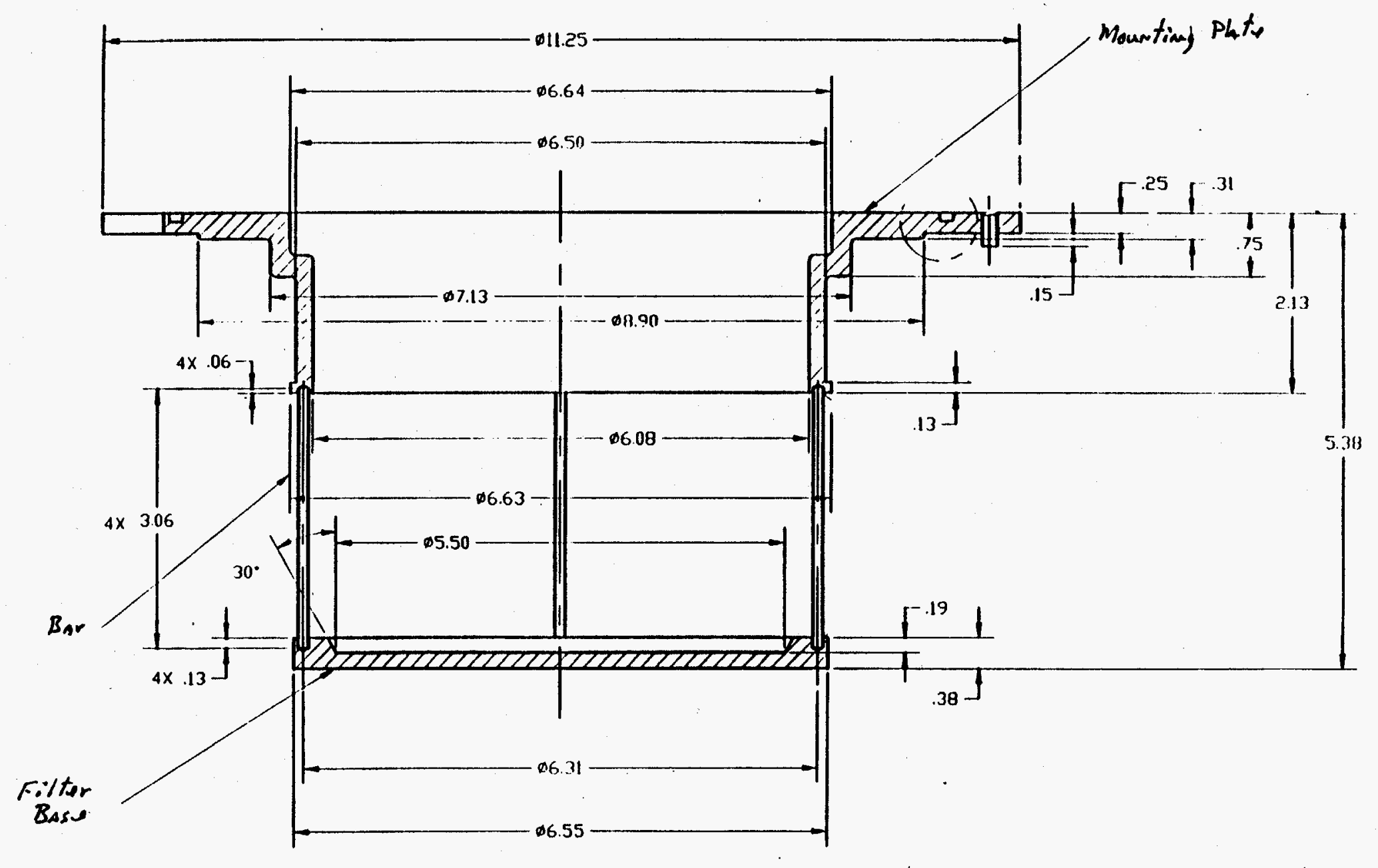

$\infty$

Fig. 5. Filter retainer. 


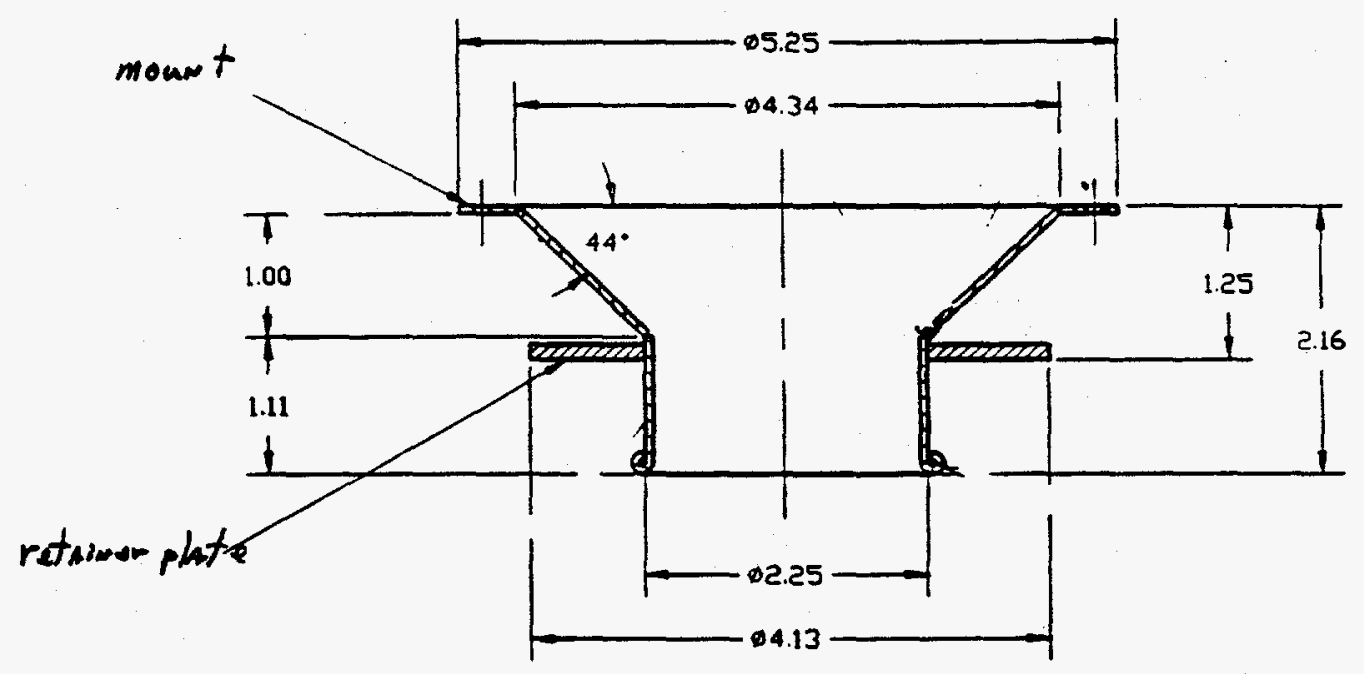

Fig. 6. Vacuum cleaner funnel. 
Table 1. Motor features and specifications

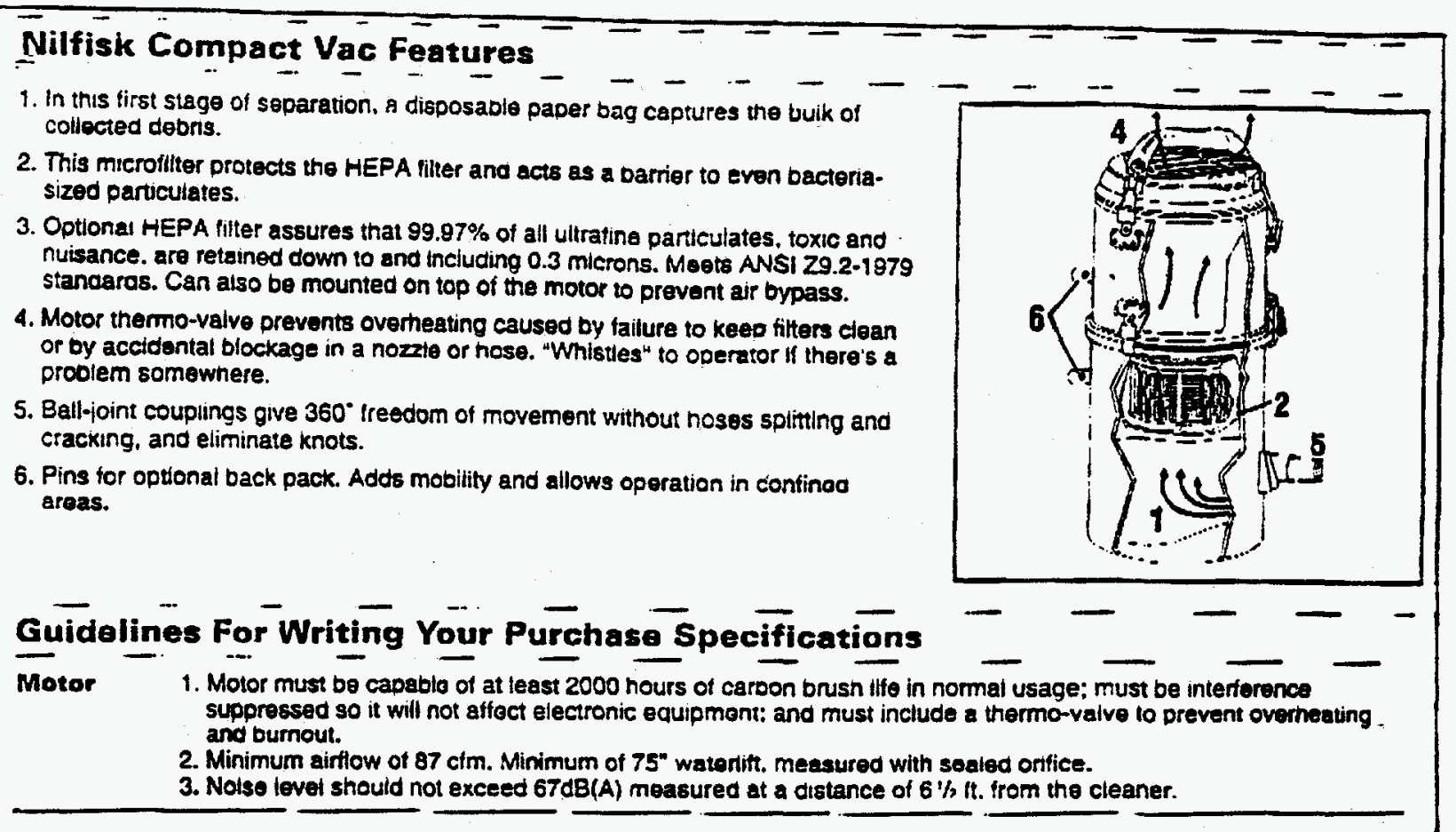

Container 1. Contalner capaciry must be approximately 1 gation dry bulk and have optional disposable paper bag.

and 2. Vacuum must have optlonal Back Pack avaijable.

Back Pack 3. Vecuum container must be stainioss steol.

Hose 1. Hose must have ballfoint connections at both ends to eliminate stress and prevent cracking. 2. Hose should be tapered to reduce risk of blockage.

Filtration 1. Vacuum must have up to threovetago filtration capability inciuding (a) disposabie paper bag. (b) mitrotiter and (c) glass fiber exnaust titter (HEPA or ULPA).

2. Microfitters must be $99.5 \%$ efficient at 2 microns. HEPA fitters must be $99.97 \%$ efficiem at 0.3 microns in panicie size. ULPA tilters must be $99.999 \%$ efficient at 0.12 microns. All HEPA and ULPA filtors must be individually DOP-tested and centffed and have a nomed sorvice life of not less than one year.

3. MEPA filters must be available to mount betore the motor of on the motor to prevent air bypass.

Warranty All ceuipment must be covered by a two-year warranty against defects in workmanship and materials. Replacement parts must bo available tor 20 years if the machine is withdrawn from prociction.

\section{Compact Vac Specifications}

Motor type. grounded

Voltage, volts

Current oraw, amps

Walts consumed, watts

Watertit, inches

Airlow. cubic $1 t . / \mathrm{min}$

Air Pertormance. air watts

Filler type: standard coton. optional Gore-Tex"

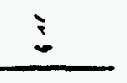

ank capacity, gal. dry bulk

Paper oag capacity, gaj. dry butk

Filter area'. square inches

Hoight, inches

Diamerer, Inches

Weight aione, tbs.

Sound level. $d B(A)$ at $6 \% / 2$ ft. from vacuum

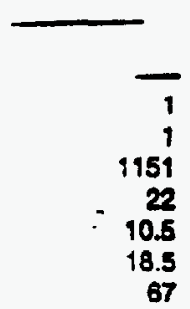

Sennderd Acceseorles: main filter, 50' power corc

Additional Accessortes: back frame, HEPA or ULPA exhaust filter, HEPA or ULPA intemal filter, paper bags Equjpment leasing is avallable. Contact your Nilfisk representative for dotails. 
Table 2. Motor parts-GSJ

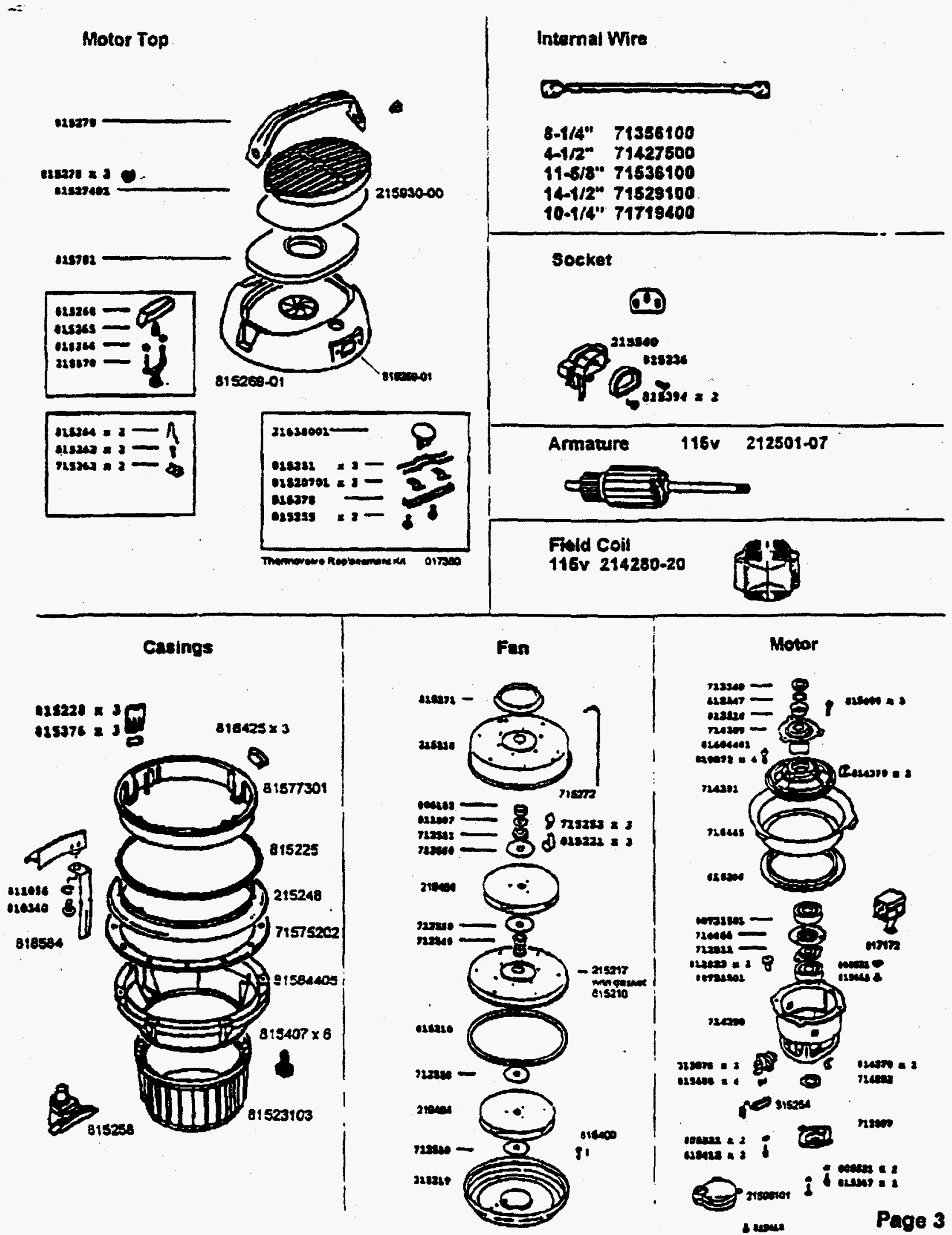


took the armature as $100 \%$ steel, the field coil as $100 \%$ steel, the fan assembly as $100 \%$ aluminum, and the motor assembly (the cast aluminum casing) as $100 \%$ aluminum. Using theoretical densities and the above weights, the material volume was calculated. The difference between the motor casing volume ( 9.0 in. ID cylinder $\times 6.75$ in. height) and material volume was taken as the motor void volume subject to filling with liquid. The motor void volume was calculated to be 10.4 in. $^{3}$ in the baseline case.

\subsection{SYSTEM SUPPORT}

The vacuum cleaner is mounted on a trolley, as shown in Fig. 2, or placed in a fixed geometry, such as a glove box. The trolley is an approximately $30-$ in. $^{2}$ device with the vacuum cleaner placed in the center. The trolley base design provides protection to the cleaner and prevents inadvertent placement of the vacuum cleaner closer than $1 \mathrm{ft}$ to other equipment. When in a fixed geometry, such as a glove box, curtain barriers or sides of the glove box control inadvertent placement of equipment close to the deposit bottle collection region. Thus, strong interaction controls can be used in a glove box fixed geometry.

The portable vacuum cleaner has a three-stage filtration system. Air flow is through a hose, through the cyclone portion of the vacuum cleaner body, and up through the downcomer. The air crosses a sock prefilter that surrounds a cylindrical HEPA filter. The air then flows through the motor and exhausts through a second HEPA filter. The DR Room glove box vacuum cleaner, on the other hand, has only the sock prefilter. The glove box HEPA filter system provides final filtration of the exhaust air.

As necessary, the deposit bottle and vacuum cleaner cyclone assembly are disconnected for cleaning and deposit bottle replacement.

\section{VACUUM CLEANER MODEL}

\subsection{CALCULATIONAL METHOD}

The SCALE computer program modules used in the criticality evaluations are part of the Standardized Computer Analysis for Licensing Evaluation (SCALE) code system. A 
summary description of the calculation procedure used in this analysis is essentially as described in ref. 4. The CSAS25 control sequence of SCALE was used for all computations. The CSAS25 control sequence activates the functional modules BONAMI-S, NITAWL-S , and KENO V.a. The control sequence and functional modules are summarized in the following paragraphs. The 27-group ENDF/B-IV cross-section library in SCALE-4.0 was used for all calculations.

The CSAS25 control sequence reads user-specific input data, which include the required cross-section library, specification for mixtures, information for resonance processing of nuclides (size, geometry, and temperature), and a detailed geometry model for KENO V.a. Physical and neutronics information, not supplied explicitly, but required by the functional modules (such as theoretical density, molecular weights, average resonance region background cross-sections), is supplied by the Standard Composition Library or calculated by the Materials Information Processor. The Standard Composition Library consists of a standard composition directory and table, an isotopic distribution directory and table, and a nuclide information table. These data were used to set up the input for BONAMI-S; NITAWL-S, and KENO V.a.

The 27-group ENDF/B-IV master cross-section library in SCALE is activated in the CSAS25 control sequence by specifying 27GROUPNDF4 (27GR) as the cross-section library name. The 27-group library is the broad companion library to the 218 -group Criticality Safety Reference Library. The Criticality Safety Reference Library master library, which is based on the ENDF/B-IV data, was generated as a pseudo-problem-independent fine-group structure library for use in general criticality safety analysis and shipping cask calculations. The 27group library was collapsed from the 218-group library using a characteristic fission- (1/E) Maxwellian spectral flux shape. Explicit ENDF/B-IV resonance parameters are carried for resonance nuclides in both 27- and 218-group libraries. These resonance parameters are used by NITAWL-S in the CSAS25 control sequence for calculating problem-dependent, selfshielded resonance region cross sections.

BONAMI-S performs resonance shielding through the application of the Bondarenko shielding factor method. BONAMI-S reads the master format library and applies the Bondarenko correction to all nuclides that have Bondarenko data. Input data to BONAMI-S, 
set up by the CSAS25 control sequence, include information relating to the physical characteristics (composition of material, size, geometry, and temperature) of the system being calculated. BONAMI-S produces a Bondarenko-corrected master format library which is read by NITAWL-S.

For the 27-group master cross-section library used in this study, the primary purpose of the BONAMI functional module is to select the required material cross sections and to create a smaller master cross-section library to be processed by NITAWL. No data processing is performed in BONAMI for the 27-group cross-section library.

NITAWL-S applies the Nordheim Integral Treatment to perform neutron crosssection processing in the resonance energy range for nuclides that have ENDF/B resonance parameter data. This technique involves the numerical integration of ENDF/B resonance parameters using a calculated flux distribution, which is based on the calculated collision density across each resonance and subsequent weighting of the reaction cross-section to the desired broad group structure. Input data to NITAWL-S, automatically set up by the CSAS25 control sequence, include information relating to the physical and neutronic characteristics of the system being calculated. NITAWL-S uses these data to complete the processing of the problem-dependent master library from BONAMI-S. In the SCALE sequence, NITAWL-S assembles the group-to-group transfer arrays from elastic and inelastic scattering components, and performs other tasks to produce a problem-dependent, working cross-section library that than can be used by KENO V.a.

KENO V.a, a multigroup Monte Carlo computer code, is used to determine $k_{\text {eff }}$ for multidimensional systems. The geometrical bodies allowed in KENO V.a for defining models include cuboids, spheres, and cylinders. KENO V.a has an enhanced geometry package that (1) allows arrays to be defined and positioned throughout the model, (2) includes a $P_{n}$ scattering treatment, (3) has an extended use of differential albedo reflection, (4) generates printer plots for checking the input model, (5) allows super grouping of energy-dependent data, (6) has a restart capability, and (7) defines origin specifications for cuboids, spheres, cylinders, hemicylinders, and hemispheres. For scoping calculations, the code used was SCALE version 4.3 for the PC, executed on a IBM clone pentium processor personal computer. 


\subsection{VACUUM CLEANER}

\subsubsection{Vacuum Cleaner Body Geometry}

The vacuum cleaner is modeled using 18 cylindrical units stacked one on another. An overall drawing of the geometrical units comprising the model is shown in Fig. 7. Unless noted, the dimensions correspond closely with the "as built" drawings M1E703045 A169 through Al77, Rev. 0, drawn in 1994. The units are assumed to be surrounded by either 1-in.- or 12-in.-thick water annuli according to the case for reflection. Beyond these annuli, an approximately 12 -in. volume of water mist is assumed to model humid air conditions in all cases. Drawing MIE703045A599 contains the originals of Figs. 7 through 18.

Unit 1 is the lower-most section, and it consists of the 1-L polypropylene collection bottle 6.75 in. high $(17.15 \mathrm{~cm})$ with an inner radius of $1.75 \mathrm{in} .(4.445 \mathrm{~cm})$ and a wall thickness of $0.0625 \mathrm{in}$. $(0.159 \mathrm{~cm})$. The bottle's inner radius is slightly smaller than $1.75 \mathrm{in}$. due to wall thickness, but this value was taken for conservatism regarding criticality. The bottle material was modeled as poly $\left(\mathrm{H}_{2} \mathrm{O}\right)$. The model and dimensions of the unit used in the computer code are shown in Fig. 8 . The bottom of the bottle was ignored.

Unit 2 is the connector between the vacuum cleaner and the neck of the bottle. The bottle screws onto the female thread of the vacuum cleaner cyclone. The height of this cylinder was measured to be less than $1-5 / 8$ in. $(4.127 \mathrm{~cm})$. The connector material was modeled as SS-304. The thickness is modeled as $0.0625 \mathrm{in} .(0.159 \mathrm{~cm})$. The outside diameter was measured to be $2.25 \mathrm{in} .(5.71 \mathrm{~cm})$, and this value was conservatively chosen as the inside diameter. This gives an inside radius of $1.125 \mathrm{in}$. $(2.857 \mathrm{~cm})$. The model is shown also in Fig. 8.

Units 3 through 6, shown in Fig. 9, are a 6-in.-high $(15.24 \mathrm{~cm})$ frustum of a cone of SS with an inside radius of 1.03 in. $(2.616 \mathrm{~cm})$ at the base and 2.43 in. $(6.18 \mathrm{~cm})$ inside radius at the top. The wall thickness is $0.059 \mathrm{in} .(0.15 \mathrm{~cm})$. The frustum is modeled as a series of pancakes stacked one on another. The radius of the pancake cylinder is the maximum radius of the section of the frustum it encompasses, as shown in Fig. 10. The actual geometry is depicted in solid line and the model is in dotted line. The first pancake is $1.38 \mathrm{in} .(3.505 \mathrm{~cm})$ in radius, which corresponds to the radius at the top of this section of the frustum. This is 


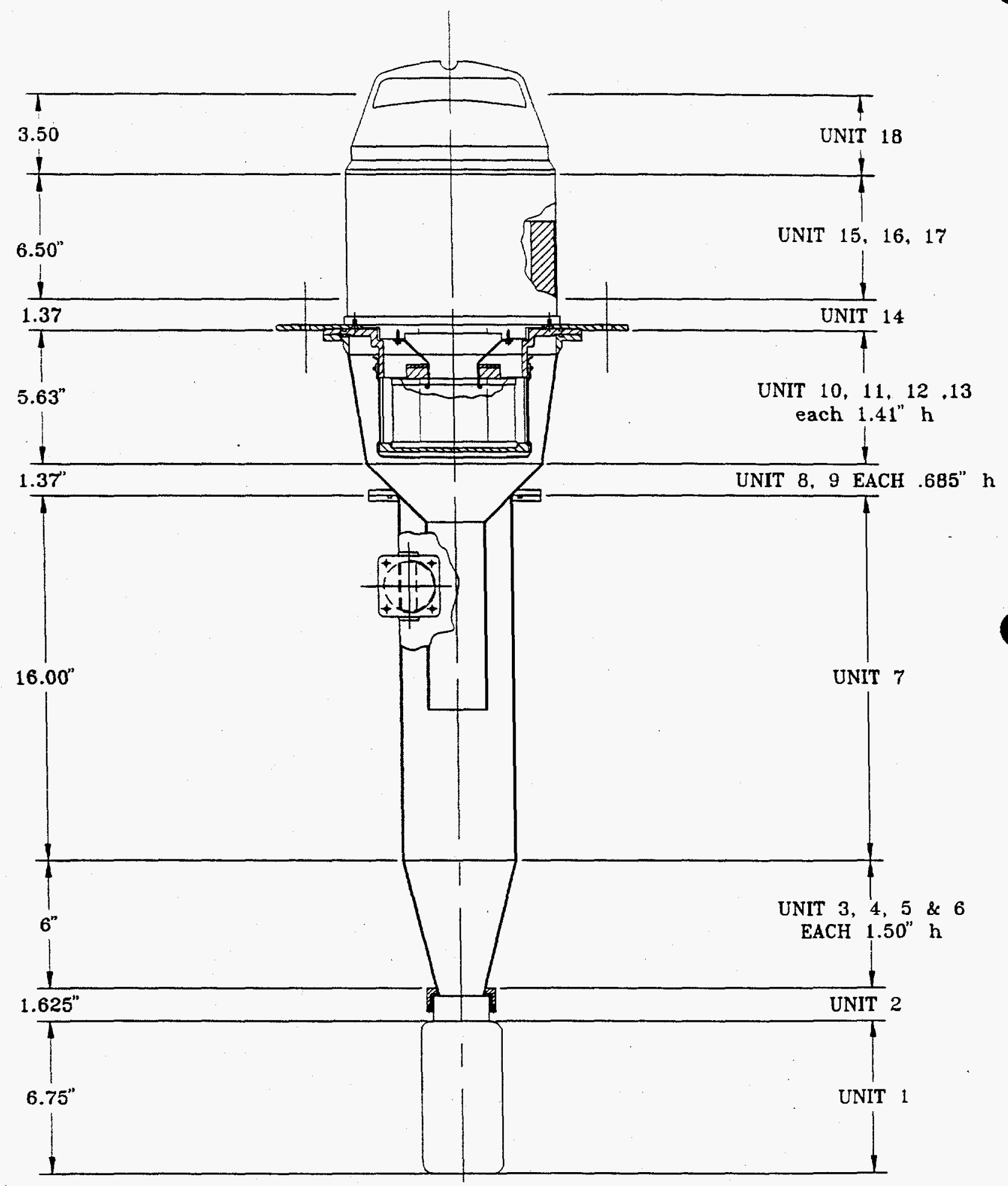

Fig. 7. Division of vacuum cleaner into cylindrical sections for modeling. 

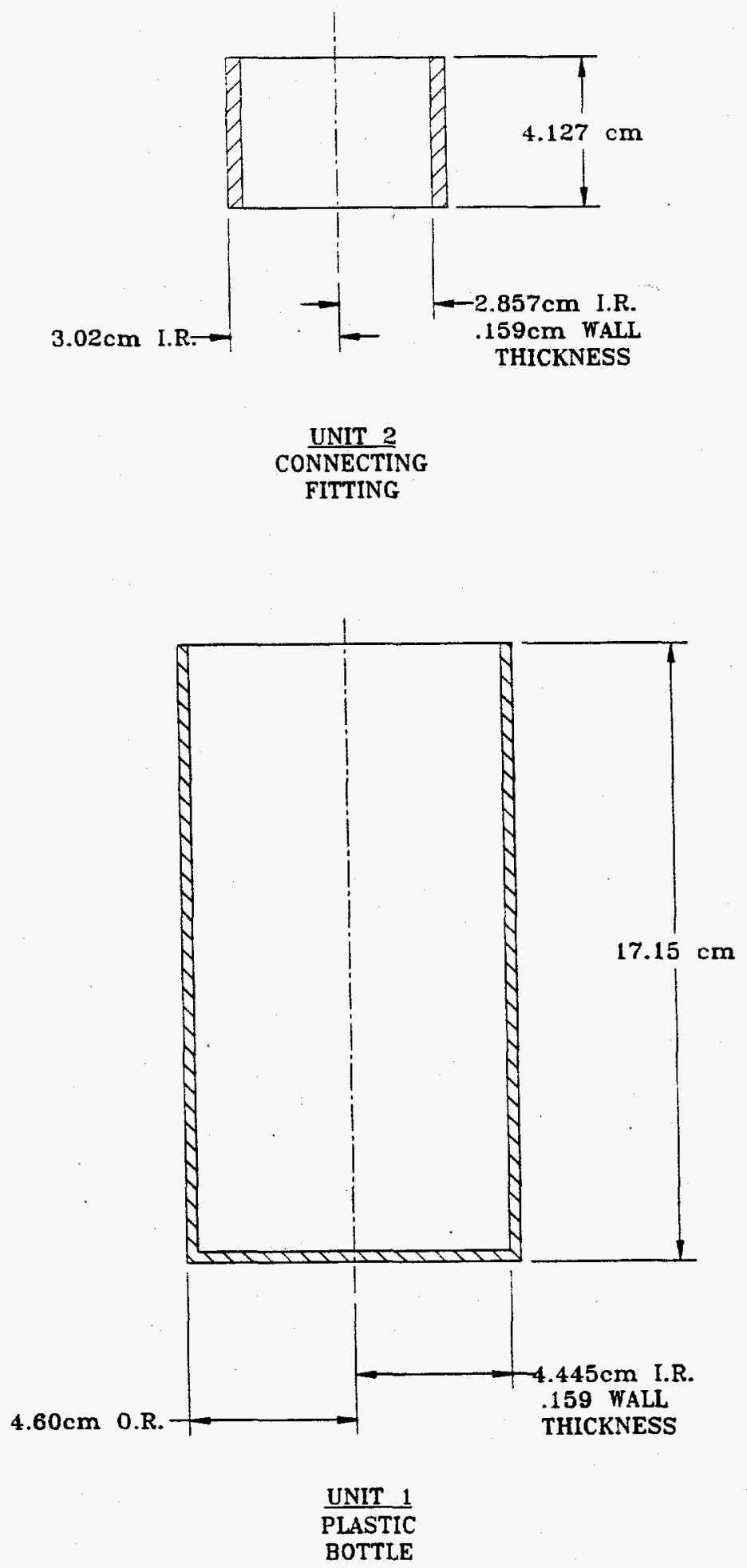

Fig. 8. Units 1 and 2: plastic bottle and connecting fitting. 
UNIT 6

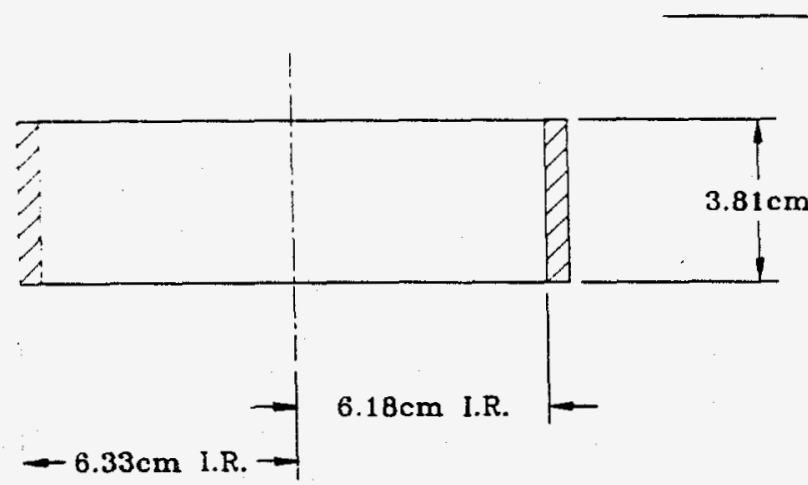

$\underline{\text { UNIT } 5}$

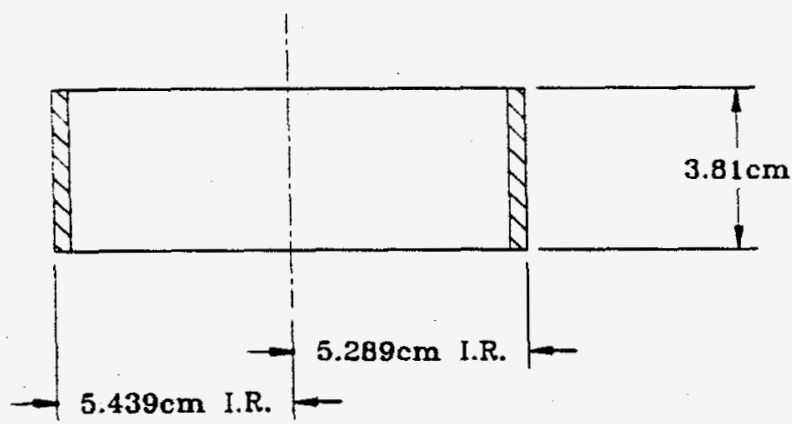

UNIT 4

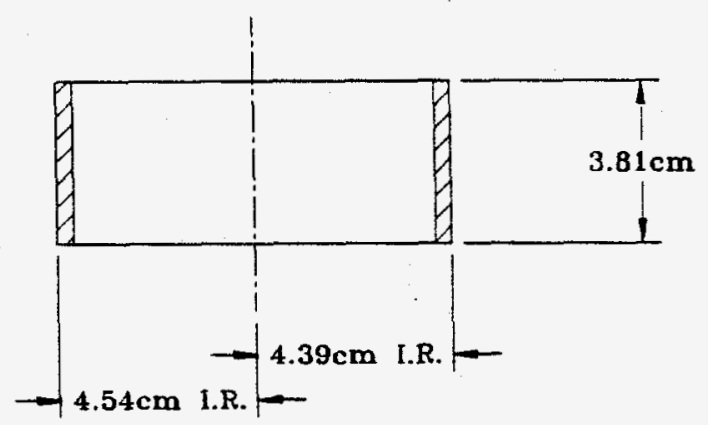

UNIT 3

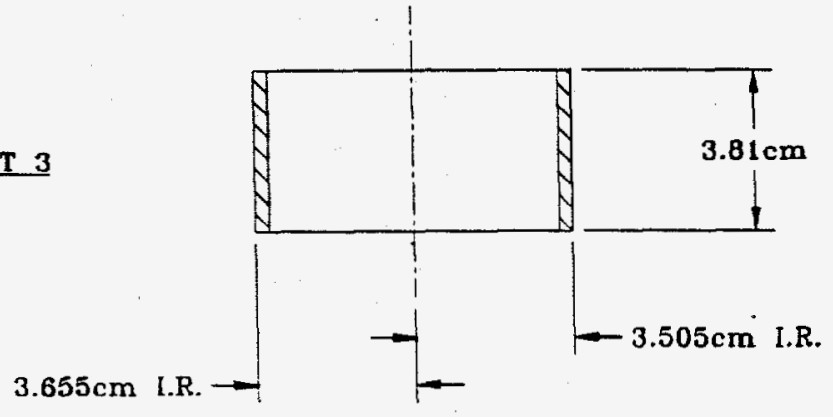

Fig. 9. Cone and frustum model of Units 3-6. 


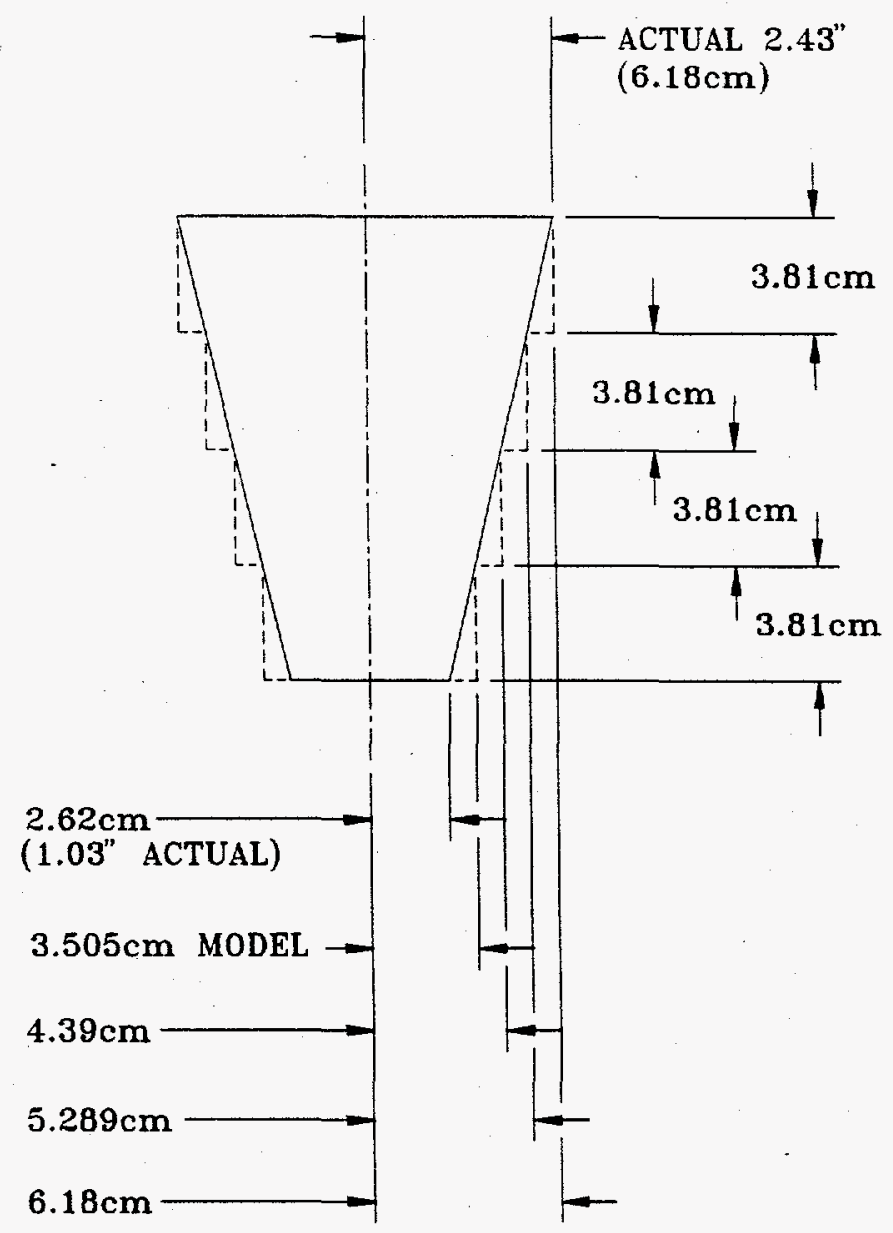

Fig. 10. Schematic of model and actual frustum, bottom of cyclone. 
conservative since the actual radius of the bottom is 1.03 in. Each unit increments the radius by $0.35 \mathrm{in} .(0.89 \mathrm{~cm})$. The volume of each pancake exceeds the volume of the conical frustum it replaces at all points to make the volume of the solution greater than it is in reality and, therefore, conservative. Each pancake is 1.5 in. $(3.81 \mathrm{~cm})$ in height. This section consists of Units 3 through 6 . As can be seen in Fig. 10, the bottoms of each model cylinder are not considered to be encased in SS but open to the water reflection volume. This should be a conservative assumption since the SS is a strong neutron absorber compared to water.

Unit 7, shown in Fig. 11, is modeled as a SS-304 cylinder of 2.435 in. internal radius $(6.185 \mathrm{~cm})$ and a wall thickness of $0.065 \mathrm{in} .(0.165 \mathrm{~cm})$. Although it contains a downcomer funnel made of steel, this part was omitted from the model, and instead, the space left vacant by its omission was replaced with uranyl fluoride solution. The steel downcomer absorbs neutrons and, therefore, this modeling is conservative. Its height is 16 in. $(40.64 \mathrm{~cm})$.

Units 8 and 9 (shown in Fig. 12) approximate a 1.37-in.-high (3.48 cm) SS-304 conical frustum. It was divided for modeling purposes into two pancakes (Units 8 and 9), each $0.685 \mathrm{in}$. $(1.74 \mathrm{~cm})$ high. The two units are $3.15 \mathrm{in} .(8.00 \mathrm{~cm})$ and $3.8 \mathrm{in} .(9.65 \mathrm{~cm})$ in internal radius, respectively. For Unit 8, this compares with a 2.5 -in. $(6.35 \mathrm{~cm})$ internal radius of the bottom of the frustum. The 2.5 -in. $(6.35 \mathrm{~cm})$ internal radius is, itself, a conservative assumption since it mates with a part which is $2.5 \mathrm{in} .(6.35 \mathrm{~cm})$ in outside radius. The wall thickness is 0.059 in. $(0.15 \mathrm{~cm})$. For Unit 9 , the actual internal radius of the top of the part is $3.8 \mathrm{in} .(9.65 \mathrm{~cm})$. The two units together are at all points larger in diameter than the actual part. The solid lines in Fig. 12 depict the actual dimensions of the part and the dotted lines depict the model dimensions.

Units 10 through 13, as shown in Fig. 13, approximate a 5.63-in.-high (14.3 cm) SS304 conical frustum. Although it contains a complicated geometry of internal parts, some of metal and some of plastic (like Units 8 and 9), it is modeled as a hollow metal cylinder filled with uranyl fluoride solution. This is consistent with earlier $\mathrm{Y}-12$ and $\mathrm{K}-25$ vacuum cleaner analyses. 5 This frustum is modeled as four pancake cylinders, as shown in Fig. 14. The actual inside diameter of the frustum is shown as the heavy line in this figure. 


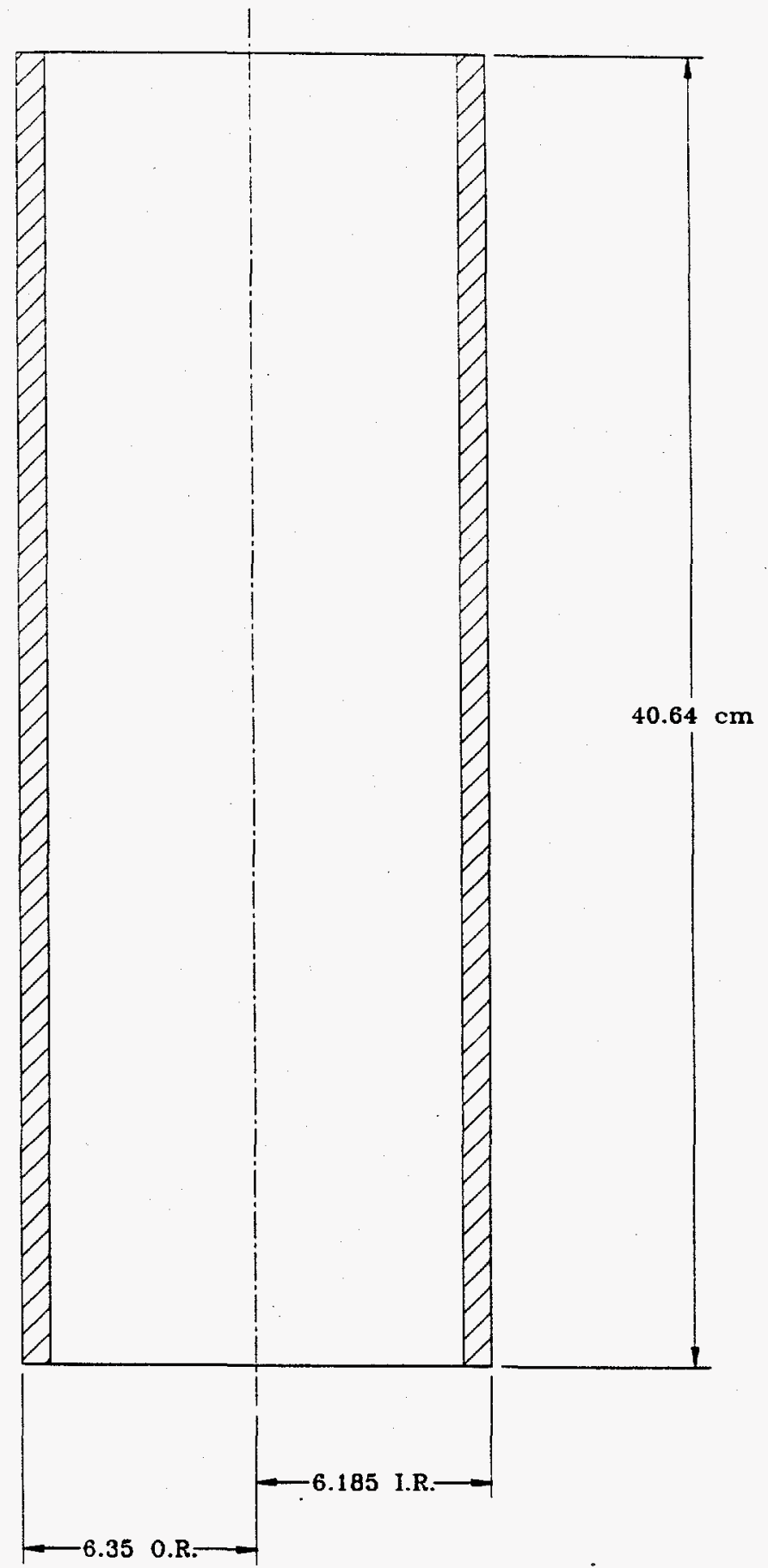

UNIT 7

Fig. 11. Unit 7: cyclone straight section. 


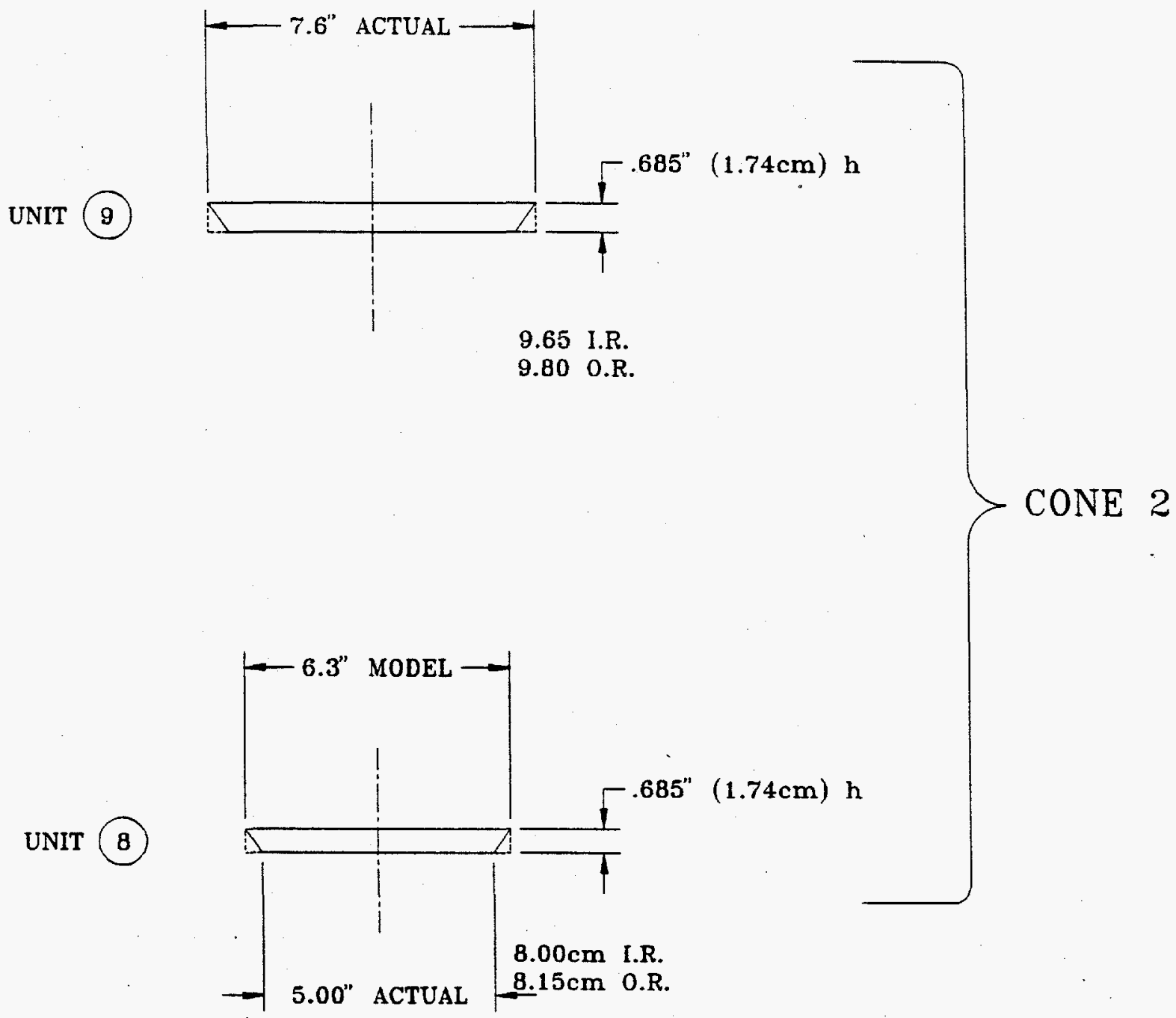

\footnotetext{
SOLID LINES DEPICT ACTUAL PART DIMENSIONS, DOTTED LINES ARE MODELING DIMENSIONS
}

Fig. 12. Units 8 and 9: model of cyclone inner body frustum. 

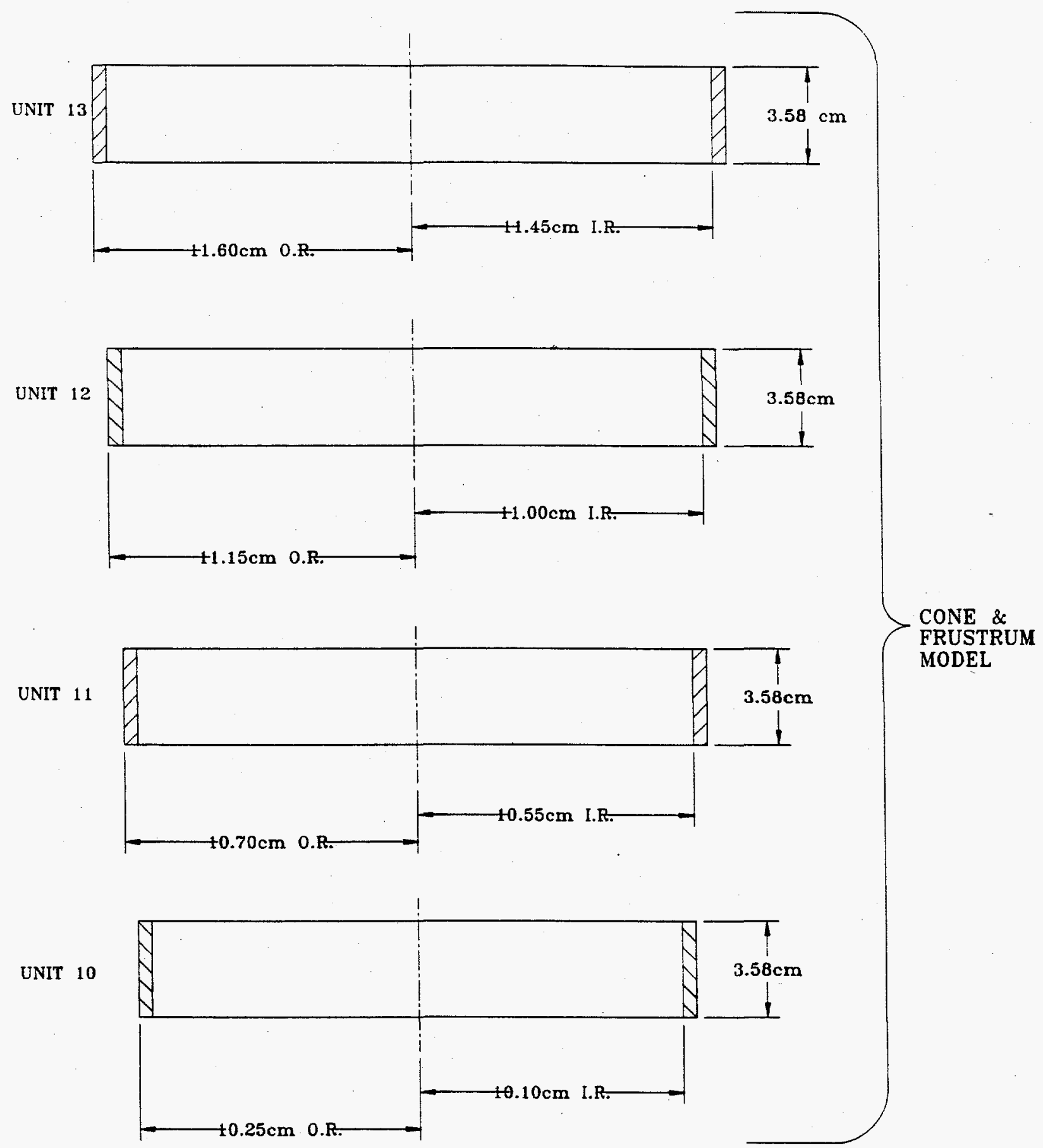

Fig. 13. Model of Units 10-13: upper frustum of cyclone inner body. 


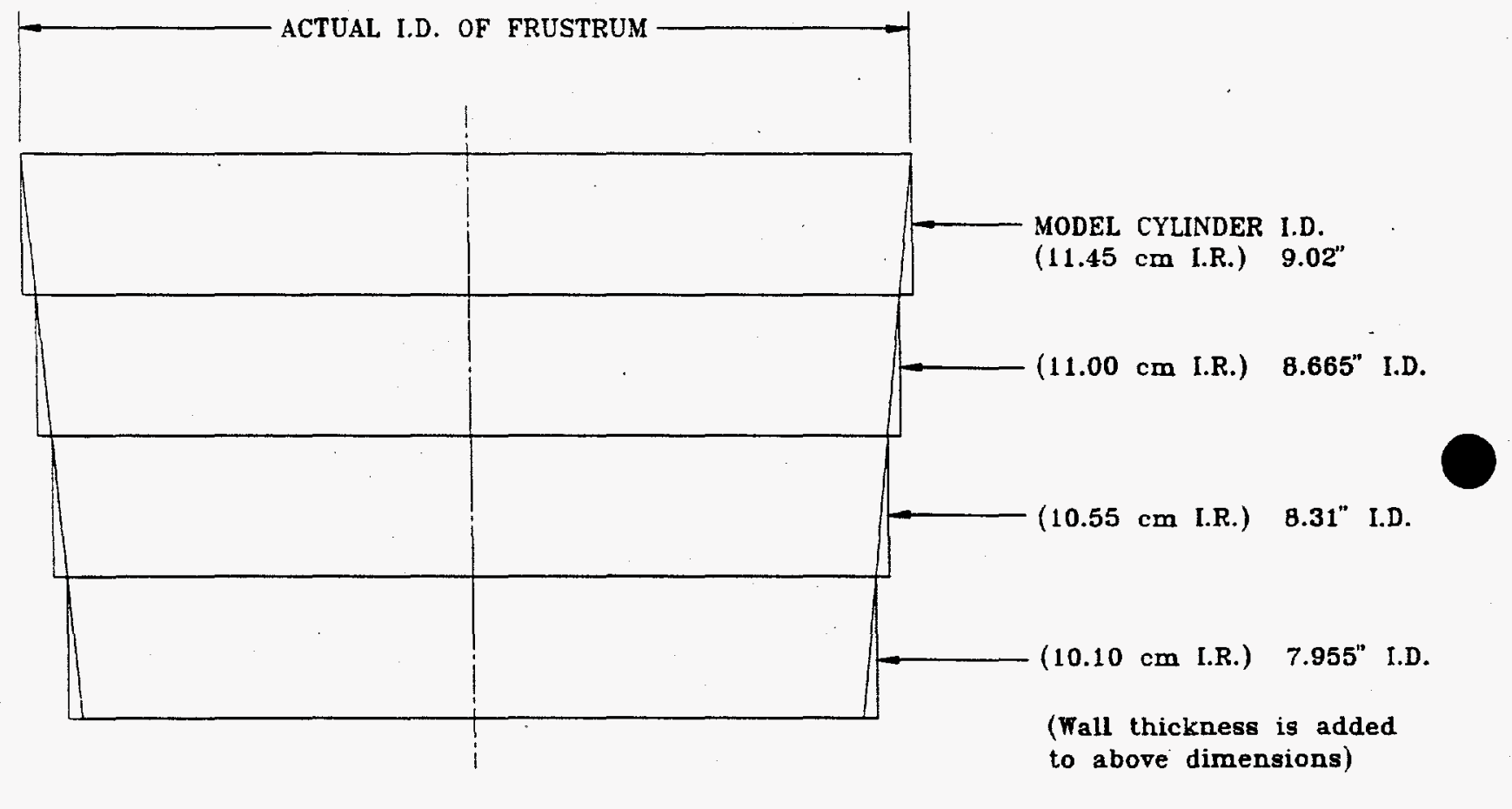

Fig. 14. Schematic of model and actual part, upper frustum of cyclone inner body. 
Each unit is of a height of 1.41 in. $(3.58 \mathrm{~cm})$ and a 0.059 -in. $(0.15 \mathrm{~cm})$ wall thickness. The base of Unit 10 has an internal radius of $3.98 \mathrm{in} .(10.1 \mathrm{~cm})$ which is larger than the actual internal radius of $3.8 \mathrm{in} .(9.65 \mathrm{~cm})$. Each unit increments the radius of the pancake by $0.1775 \mathrm{in} .(0.45085 \mathrm{~cm})$ until the internal radius of $4.51 \mathrm{in}$. $(11.455 \mathrm{~cm})$ at the top of the frustum.

Unit 14, shown in Fig. 15 as the "flange section", is a 1.37-in.-high $(3.48 \mathrm{~cm})$ cylinder 9 in. diam $(22.9 \mathrm{~cm})$ which covers the vacuum cleaner mounting plate, adaptor plate, and cyclone inner body flange sections. The total thickness of the flanges and plates was calculated to be $1.37 \mathrm{in} .(3.48 \mathrm{~cm})$ and, although this volume contains a quantity of steel, it was modeled as a $11.45-\mathrm{cm}$ IR by $0.15-\mathrm{cm}$-thick SS-304 cylinder containing uranyl fluoride solution.

Unit 15, also shown in Fig. 15 and in detail in Fig. 16, is a 0.5-in.-tall $(1.27 \mathrm{~cm})$ cylinder with a void to a radius of $3.5 \mathrm{in} .(8.89 \mathrm{~cm})$, and then a plastic annulus from $8.89 \mathrm{~cm}$ to $4.51 \mathrm{in} .(11.45 \mathrm{~cm})$. No motor parts are in the model of this unit.

Unit 16, also shown in Fig. 15 and shown in detail in Fig. 17, consists of an inner cylinder to a radius of $1.75 \mathrm{in}$. $(4.445 \mathrm{~cm})$ which comprises the motor assembly. Then, an annular section begins between $4.445 \mathrm{~cm}$ and $3.5 \mathrm{in} .(8.899 \mathrm{~cm})$ which is modeled as uranyl fluoride solution. The next annulus from $8.89 \mathrm{~cm}$ to $11.45 \mathrm{~cm}$ is composed of plastic. A 0.059 -in. $(0.15 \mathrm{~cm}) \mathrm{SS}$ cylinder then houses the assembly. The motor is assumed to consist of a reduced density of aluminum, iron, and/or copper mixed with $\mathrm{UO}_{2} \mathrm{~F}_{2}$ solution as will be explained in Sect. 3.2.2. This unit is $3.63 \mathrm{in} .(9.22 \mathrm{~cm})$ high.

Unit 17, also shown in Fig. 15 and shown in detail in Fig. 17, consists of a cylinder, the first $1.75 \mathrm{in}$. $(4.445 \mathrm{~cm})$ of which is comprised of the motor assembly. The remaining annulus from 1.75 in. $(4.445 \mathrm{~cm})$ to 4.51 in. $(11.45 \mathrm{~cm})$ is void volume to be filled with solution. The motor is assumed to consist of a reduced density of aluminum, iron, and/or copper mixed with $\mathrm{UO}_{2} \mathrm{~F}_{2}$ solution, as will be explained in Sect. 3.2.2. This unit is 2.37 in. $(6.02 \mathrm{~cm})$ high. The SS-304 wall thickness was 0.059 in $(0.15 \mathrm{~cm})$.

Unit 18, shown in Fig. 18, models the upper HEPA filter and casing. Data from the manufacturer indicate that the diameter of the HEPA container is 5 in. $(12.7 \mathrm{~cm})$, and the height is $3.5 \mathrm{in}$. $(8.89 \mathrm{~cm})$. The region is filled with uranyl fluoride solution for purposes of the model. A 0.059 -in.-thick $(0.15 \mathrm{~cm})$ SS-304 wall was modeled. 

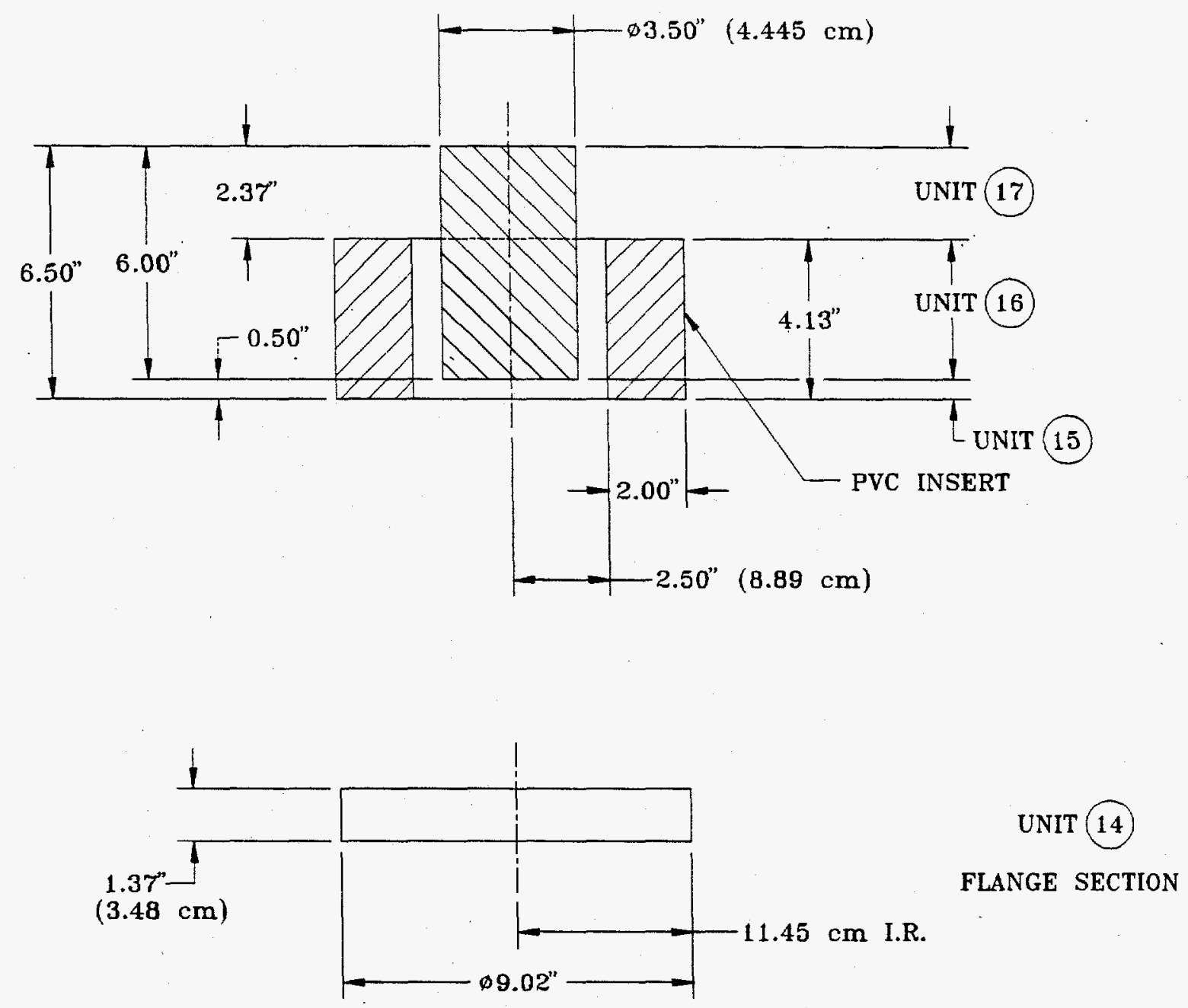

Fig. 15. Model of Units 14, 15, 16, and 17: flange section and motor assembly. 


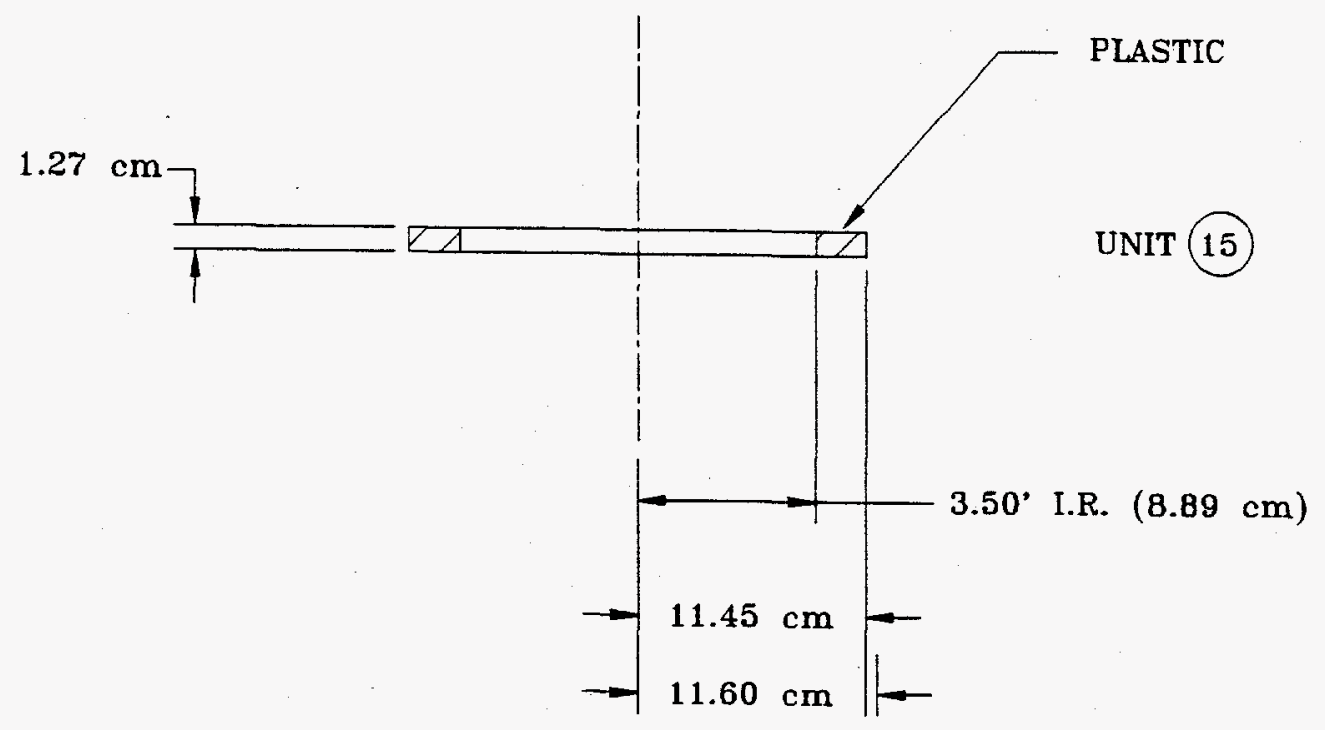

Fig. 16. Model of Unit 15: motor base assembly. 

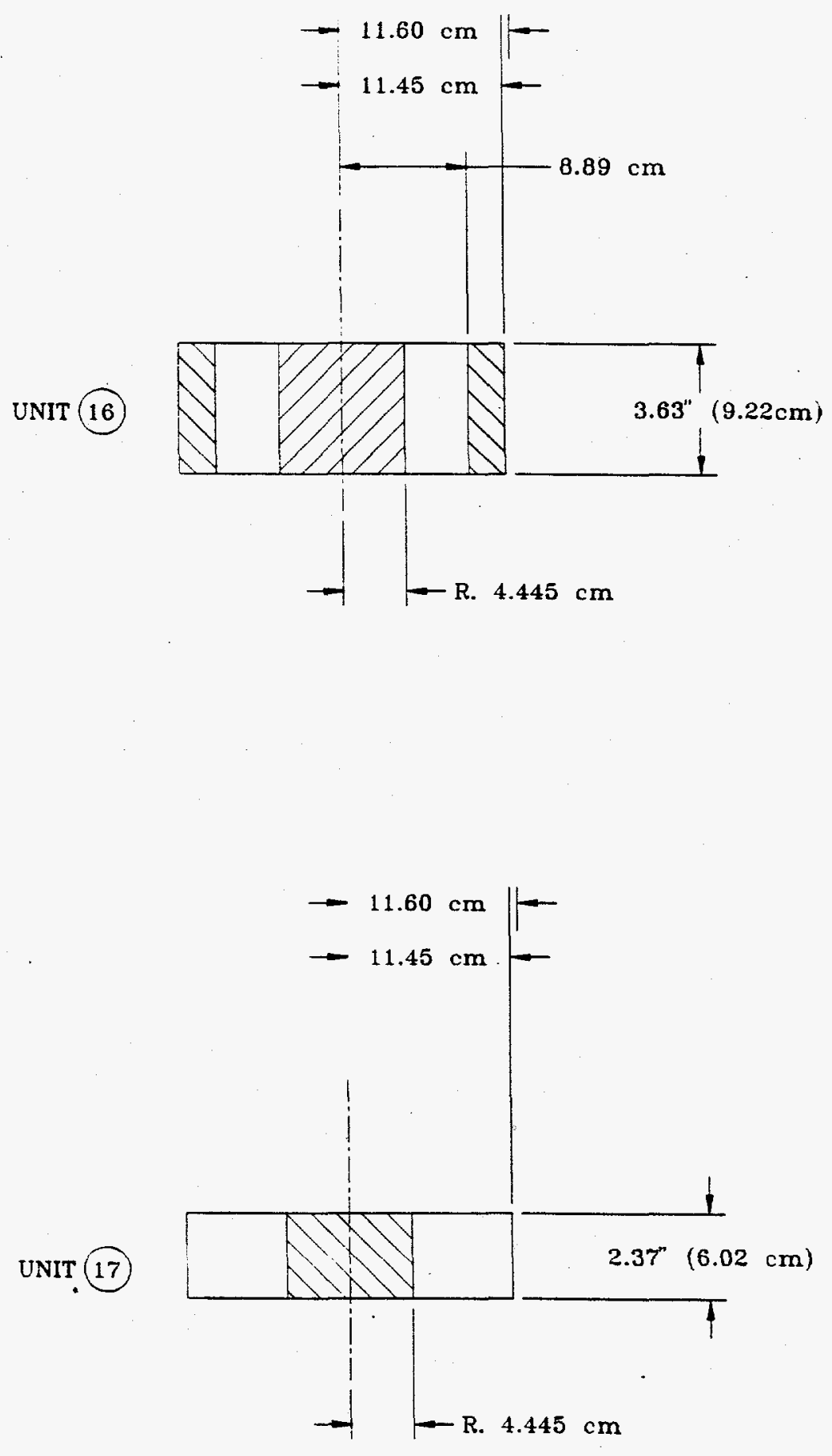

Fig. 17. Model of Units 16 and 17: motor assembly. 


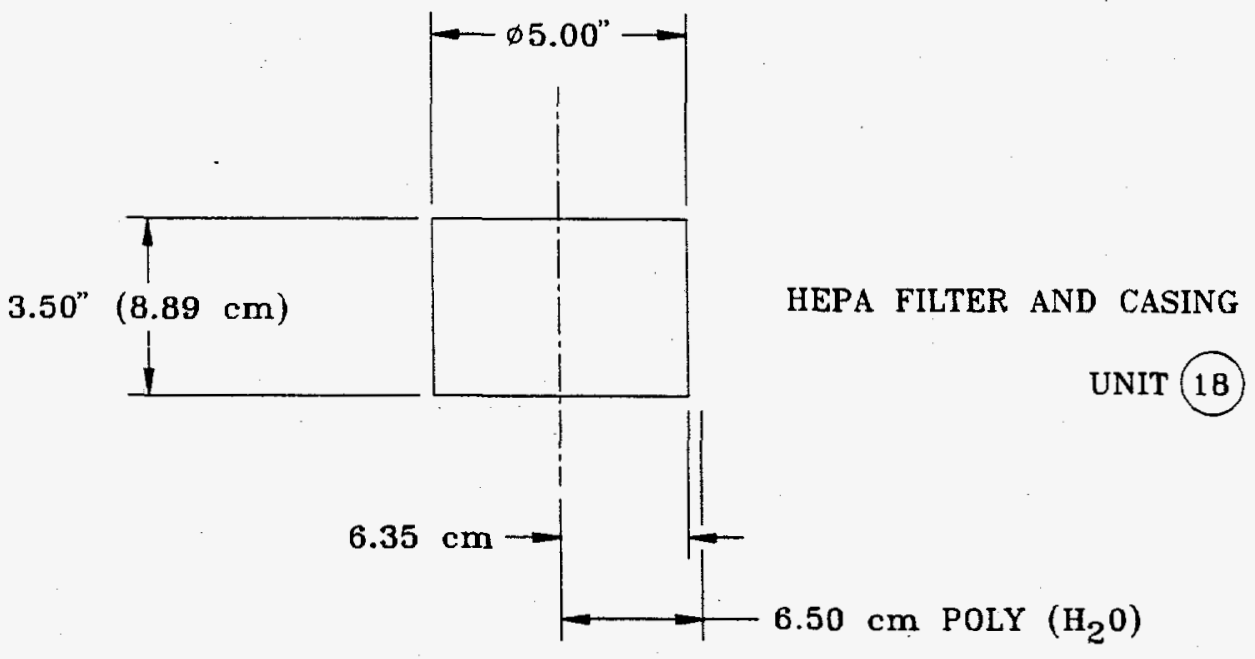

Fig. 18. Unit 18: HEPA filter and casing. 


\subsubsection{Vacuum Cleaner Motor Geometry and Materials}

Units 15, 16, and 17 are a complicated section consisting of uranyl fluoride solution, a plastic annulus, and a central core which models the motor and fan assembly, as shown schematically in Fig. 15. Figure 15 shows the dimensions used in modeling. Also shown at the top of these two figures, but modeled in Unit 18, is the HEPA filter housing. As shown in Fig. 19, the motor/fan assembly begins at a diameter of $3.5 \mathrm{in} .(8.89 \mathrm{~cm})$ and expands to a 6.5 -in.-diam $(16.51 \mathrm{~cm})$ at the point it mates approximately with the HEPA filter housing. The greatest uncertainty exists in the characteristics and geometry of the motor fan assembly. As indicated, the geometry is modeled only as a 3.5-in.-diam cylinder of 6-in. height. Although the upper section of the assembly slopes outward to a diameter of $6.5 \mathrm{in}$., the smaller diameter is assumed to exist throughout the length of the assembly, and the increased void volume resulting from this model is assumed to contain entirely uranyl fluoride solution.

This is felt to be conservative because no information on the void volume of this section of the assembly is available. Figure 20 is a drawing that is made from measurements of a partially disassembled motor, Model GSJ-1 15, from Nilfisk of America. Figure 20 shows roughly the materials of construction of the parts of the motor and fan assembly. The motor is surrounded by a 0.0625 -in.-thick $(0.0159 \mathrm{~cm})$ plastic cone as shown in Figs. 19 and 20. This plastic cone was omitted in this analysis and the space was filled with uranyl fluoride solution. At the base of this unit, there is a thin rubber gasket upon which the motor assembly rests in a vacuum cleaner as inspected at Machine Kinetics Corporation of Knoxville. This gasket space was also replaced with solution. The annular polyvinylchloride (PVC) plastic cylinder is modeled geometrically as it appears on the drawings -2 in. $(5.08 \mathrm{~cm})$ thickness, $4.13 \mathrm{in} .(10.49 \mathrm{~cm})$ high. It fits into the bottom of the motor/fan assembly section but was modeled as polyethylene, which is a lower neutron absorber than PVC. This plastic cylinder was placed there to occupy space which might otherwise fill with uranyl fluoride solution.

The steel wall of the vacuum cleaner was modeled as SS-304; the drawing specifies 300 series SS. Plastic parts are modeled using the Bonami library microscopic cross sections of hydrogen with a water thermal kernel in all of the plastic units. Although certain parts are believed to be PVC (rather than polyethylene), a conservative assumption is that they are polyethylene since it has a lower neutron absorbance cross section than PVC due to the 
VACUUM CLEANER MOTOR / FAN ASSEMBLY

DIMENSIONS

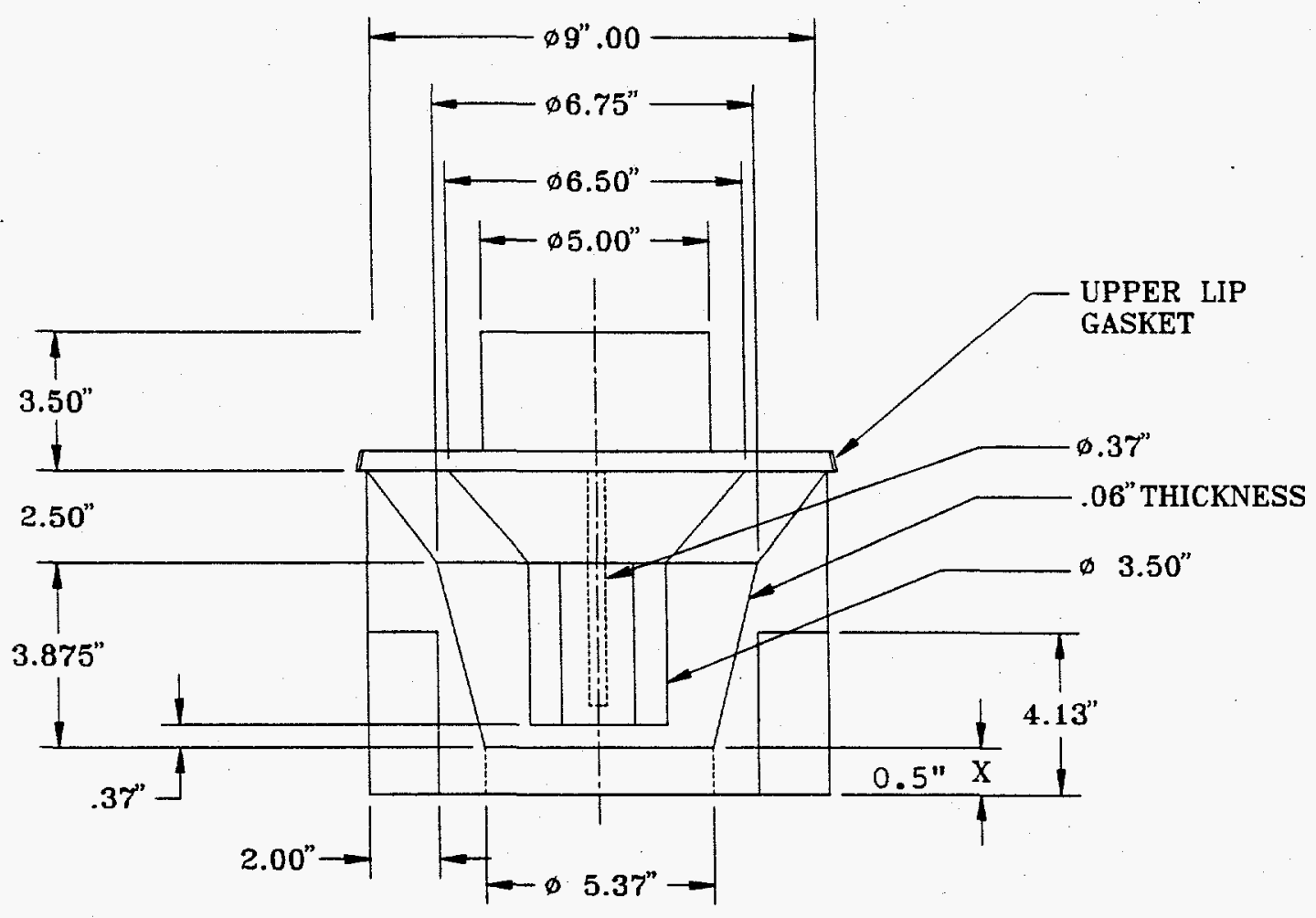

Fig. 19. Schematic of actual motor assembly approximate dimensions. 


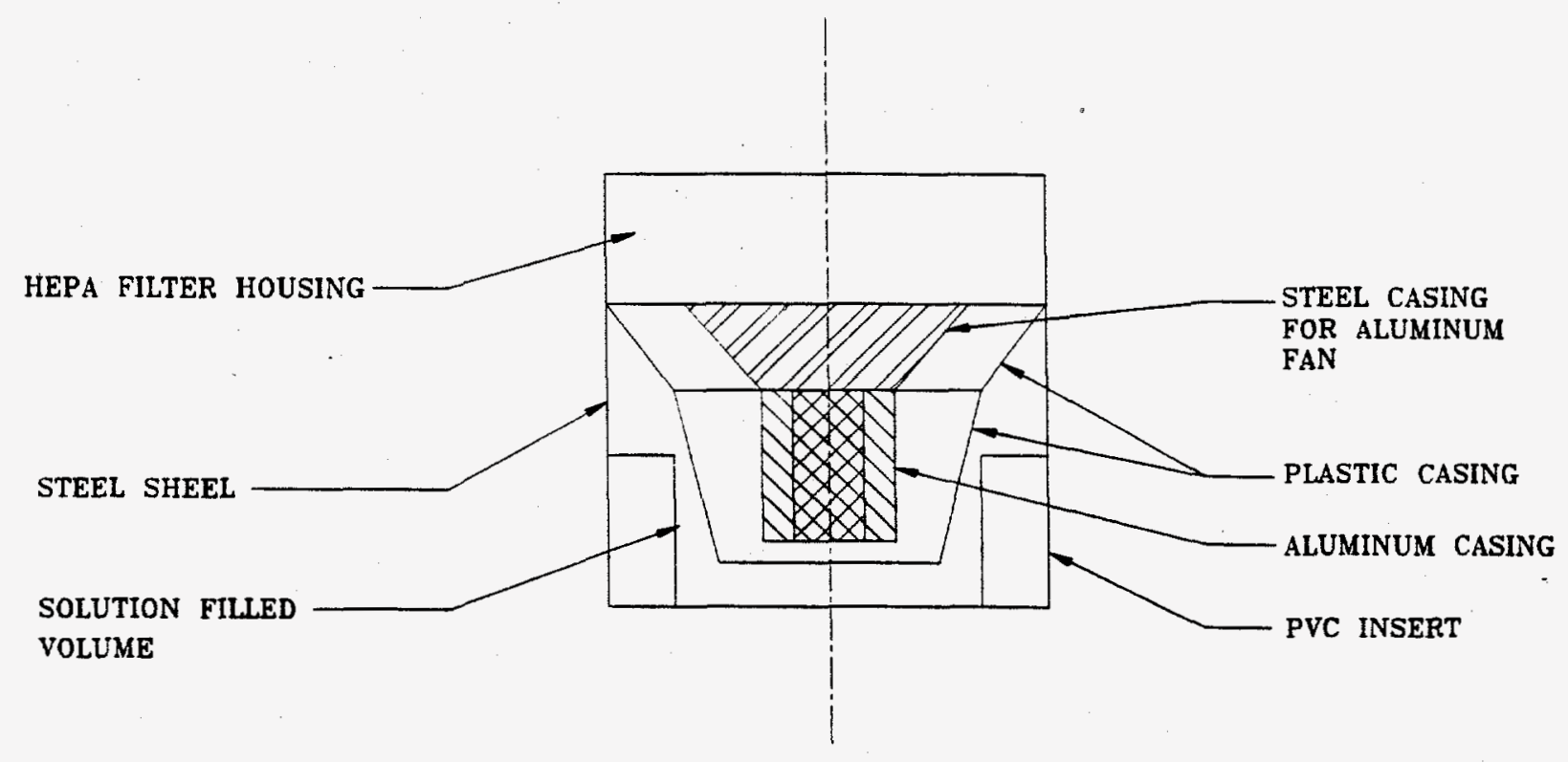

LEGEND
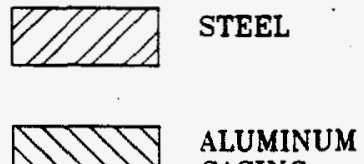

CASING

MOTOR

PLASTIC OR VOID

Fig. 20. Schematic of actual motor assembly materials based on Nilfisk parts. 
chlorine in the PVC. Polyethylene has a comparable atomic density of hydrogen to polypropylene and the same model is used with both materials. The polypropylene material was modeled as poly $\left(\mathrm{H}_{2} \mathrm{O}\right)$ according to the Bonami library of neutron cross sections.

The masses of the armature, field coil, fan assembly, and motor assembly, were provided by Nilfisk Corp. of America. Their dimensions and masses are shown in Appendix B. A KENO-code-generated map of the vacuum cleaner is shown in Appendix C.

\subsection{BASELINE MODEL}

The entire vacuum cleaner is modeled as a stack of the 18 units shown in Fig. 7 and described in the previous section. All sections not explicitly defined as being of a solid material in the model are assumed to be filled with uranyl fluoride solutions of various concentrations. The total volume was calculated to be $20 \mathrm{~L}$. The volumes of the individual units (Units 1 through 18) are shown in Appendix D. A second calculation of the actual volume (less conservative from the point of view of calculating total critical masses) was performed. The resulting volume was $1910 \mathrm{cc}$ and the calculations were performed with Math Cad are shown in Appendix E.

\section{Baseline Case 1:}

The motor section geometry and materials are subject to the most uncertainty and several sensitivity calculations around a baseline case were made. As a baseline case, the armature and field coils, composed of iron and copper, were taken to consist entirely of iron. Copper is a large neutron absorber and treating the armature and field coils as iron is conservative. All aluminum/iron parts are modeled as consisting of aluminum alone because iron is a better neutron absorber than aluminum. Iron was calculated to have an atomic density of 0.017 atoms $/ \mathrm{b} \cdot \mathrm{cm}$ (based on a mass density of $7.86 \mathrm{~g} / \mathrm{cc}$ ) and aluminum to have a density of 0.0375 atoms $/ \mathrm{b} \cdot \mathrm{cm}$ (based on a mass density of $2.7 \mathrm{~g} / \mathrm{cc}$ ). Calculations are shown in Appendix A. The total volume of the cylindrical section which models the motor fan assembly is 10.4 in. $^{3}$ ( $\left.945 \mathrm{cc}\right)$. A void fraction of $18 \%$ was calculated based on a mass balance of motor parts. This void space is filled with uranyl fluoride solution as are other void sections of the vacuum cleaner. The calculations of densities are shown in Appendix A. KENO V.a 
calculations for 1 -in. and 12-in. reflection were performed for uranium concentrations from 30 to $130 \mathrm{~g} / \mathrm{L}$.

Sensitivity calculations about the base case:

Sensitivity calculations were performed around the base case of motor materials composition. Physically, the void fraction inside the motor is fixed once an assumption about the materials of construction, their masses, and the motor volume is made. Case 2 considered iron/copper parts to be all copper; copper/aluminum parts were considered to be all aluminum. The sensitivity of the analysis was then examined for this change in composition. Case 3 mixture of $50 \% \mathrm{Fe}, 50 \% \mathrm{Cu}$ was considered also. Case 4 examined the motor as being entirely absent and its void filled with solution. KENO calculations for 1-in. and 12-in. reflection were performed. Table 3 shows the models and baseline cases which were tried.

\subsection{DIFFERENCES BETWEEN CURRENT AND EARLIER MODELS}

The present K-25 portable vacuum cleaner, per drawing M1E703045, has undergone several modifications from earlier versions used at $\mathrm{Y}-12$. The present $\mathrm{K}-25$ vacuum cleaner has eliminated a polypropylene disk located near the mounting plate. In the present analysis, this space left vacant by the disk was assumed to be filled with uranyl fluoride solution. The

Table 3. Composition of motor parts modeled in four cases

\begin{tabular}{lcccc}
\hline Model & $\begin{array}{c}\text { Case 1, } \\
\text { baseline }\end{array}$ & Case 2 & Case 3 & Case 4 \\
\hline Armature & $100 \% \mathrm{Fe}$ & $100 \% \mathrm{Cu}$ & $50 \% \mathrm{Fe}, 50 \% \mathrm{Cu}$ & $100 \%$ fissile solution \\
Field coil & $100 \% \mathrm{Fe}$ & $100 \% \mathrm{Cu}$ & $50 \% \mathrm{Fe}, 50 \% \mathrm{Cu}$ & $100 \%$ fissile solution \\
Fan assembly & $100 \% \mathrm{Al}$ & $100 \% \mathrm{Al}$ & $100 \% \mathrm{Al}$ & $100 \%$ fissile solution \\
$\begin{array}{l}\text { Motor assembly } \\
\text { Fissile solution, }\end{array}$ & $100 \% \mathrm{Al}$ & $100 \% \mathrm{Al}$ & $100 \% \mathrm{Al}$ & $100 \%$ fissile solution \\
fraction \% & 18 & 20 & 19 & $100 \%$ \\
\hline
\end{tabular}


present K-25 vacuum cleaner model includes a flange at the top of the cyclone which permits the removal of the cyclone to facilitate cleaning. The flange does not affect criticality safety calculations.

Unpublished K-25 Site analysis modeled the various frusta of cones by creating a complicated arrangement of layered disks which equaled the volume of the actual hardware. Different thicknesses of the SS steel wall were used and, in certain cases, these were much greater than the actual wall thickness. In the present model of the $\mathrm{K}-25$ vacuum cleaner, cylinders are again layered one on another; however, the volume of the disks is adjusted so that it exceeds at all points the actual volume of the hardware. Although the sums of volumes in the earlier work are identical to that of the actual parts, the individual cylinders, on occasion, are smaller than the actual volumes and, on occasion, larger. The current model is more conservative since it assumes that at all points the modeled volume is greater than the actual volume. It is not clear why greater wall thicknesses than the actual hardware were chosen in the unpublished earlier analysis. Since the SS is a neutron absorber and a poor moderator, the present more realistic model of the wall thickness should also be more conservative.

This work gathered more information about the internal structure of the Nilfisk motor than was available in earlier analyses. Information on the weights of the four parts of the motor assembly was obtained from Nilfisk Corp. and is used in the present modeling. Where data were unavailable as, for example, in the compositions of the different parts, sensitivity calculations were made over the range of possible compositions. The dimensions of an actual plastic uranium collection bottle at the bottom were measured and input to the present model as indicated in Sect. 3.2.1.

Notable modeling assumptions:

1. Miscellaneous vacuum cleaner components (filters, motor housing, downcomer from filter/motor region into the cyclone, etc.) are not modeled in the KENO V.a calculations. Such components provide some neutron absorption and displace fissile solution. Thus, these components, if included, would lower reactivity and increase the calculated critical mass. 
2. Plastic components were modeled as polyethylene rather than PVC. The chlorine in PVC should provide additional neutron poisoning.

3. Full flooding. The vacuum cleaner is filled with liquid to a height exceeding the top of the electric motor; the motor would cease functioning on flooding. It is not expected that the vacuum cleaner could draw liquid to a height above the hose inlet to the cyclone and the equipment below this height is safe geometry for $\mathrm{UO}_{2} \mathrm{~F}_{2}$ solutions. Typically, administrative controls direct that the vacuum cleaner be used for collecting dry material only. Also, typically, the vacuum cleaner is designed to shed overhead water. For example, Fig. 1 shows a hat above the motor which is designed to prevent water from entering from above. Alternatively, the vacuum cleaner is placed in an enclosure, e.g., glove box, to protect it from sources of liquid.

4. Full reflection (12 in. water) establishes the minimum critical mass. Full reflection is unlikely in reality. There would be partial reflection from concrete, nearby structural equipment, air, and personnel.

5. Interaction effects are not modeled because the 12 in. of water reflection isolates the vacuum cleaner from other equipment in the model. Typically, the vacuum cleaner has physical barriers, e.g., sits on a trolley with stand-off bars, to prevent the vacuum clenner from coming into contact with other fissile-containing equipment. Alternatively, the vacuum cleaner is placed in a fixed geometry, e.g., glove box, where spacing can be controlled among equipment.

\section{ANALYSES}

Calculations were conducted for and about the base case which modeled the vacuum cleaner geometries and materials of composition. The calculation base case uses realistic, though conservative, assumptions. Where there were uncertainties (e.g., the precise motor materials composition), bounding sensitivity calculations were performed. 


\subsection{RESULTS}

\section{Case 1, Baseline $100 \%$ iron motor parts}

The baseline case considered the iron and copper motor parts (the armature and field coil) to consist only of iron. Aluminum and iron parts are assumed to consist only of aluminum, since aluminum is a low neutron absorber. The calculated $k_{\text {eff }}$ are shown in Table 4 . The $k_{\text {eff }}$ chosen are the average $k_{\text {eff }}$ which occurs for 103 generations run without skipping any generations. Values were obtained for uranium concentrations from 30 to $130 \mathrm{~g} / \mathrm{L}$ at 1 -in. and 12-in. water reflection. Graphs of these results are shown in Figs. 21 and 22 with error bars indicating the $2 \sigma, 95 \%$ confidence interval of the data based on two standard deviations. With 12-in. reflection and a concentration of $70 \mathrm{~g} / \mathrm{L}$ of uranium, $k_{\text {eff }}$ plus two standard deviations approaches 0.95 . With 1 -in. reflection and a concentration of $100 \mathrm{~g} / \mathrm{L}$ of uranium, $k_{\text {eff }}$ plus two standard deviations approaches 0.95 . The data at 1 -in. reflection are a bit more scattered than those at 12 -in. reflection. Note that $k_{\text {eff }}$ is well below 1.0 for all 1 -in. reflection

Table 4. Baseline case results: $100 \%$ iron motor parts

\begin{tabular}{rlll||cccc}
\hline \hline \multicolumn{4}{c|}{ 12-in. reflection } & \multicolumn{5}{c}{1 -in. reflection } \\
\hline $\mathrm{g} \mathrm{U} / \mathrm{L}$ & \multicolumn{1}{c|}{$k_{\text {eff }}$} & $2 \sigma$ & $k_{\text {eff }}+2 \sigma$ & $\mathrm{g} \mathrm{U} / \mathrm{L}$ & $k_{\text {eff }}$ & $2 \sigma$ & $k_{\text {eff }}+2 \sigma$ \\
\hline \hline 30 & 0.7356 & 0.0082 & 0.7438 & 30 & 0.6807 & 0.009 & 0.6897 \\
40 & 0.8061 & 0.008 & 0.8141 & 40 & 0.7495 & 0.0092 & 0.7587 \\
50 & 0.8587 & 0.01 & 0.8687 & 50 & 0.7982 & 0.0094 & 0.8076 \\
60 & 0.8999 & 0.01 & 0.9099 & 60 & 0.8455 & 0.0094 & 0.8549 \\
70 & 0.9314 & 0.0094 & 0.9408 & 70 & 0.8682 & 0.0104 & 0.8786 \\
80 & 0.958 & 0.0102 & 0.9682 & 80 & 0.8871 & 0.0118 & 0.8989 \\
90 & 0.9868 & 0.0106 & 0.9974 & 90 & 0.903 & 0.0110 & 0.914 \\
100 & 0.9989 & 0.0068 & 1.0057 & 100 & 0.9332 & 0.0108 & 0.944 \\
110 & 1.0118 & 0.0108 & 1.0226 & 110 & 0.9353 & 0.0112 & 0.9465 \\
120 & 1.0142 & 0.0108 & 1.025 & 120 & 0.9661 & 0.0118 & 0.9779 \\
130 & 1.0439 & 0.0114 & 1.0553 & 130 & 0.9608 & 0.0116 & 0.9724 \\
\hline \hline
\end{tabular}




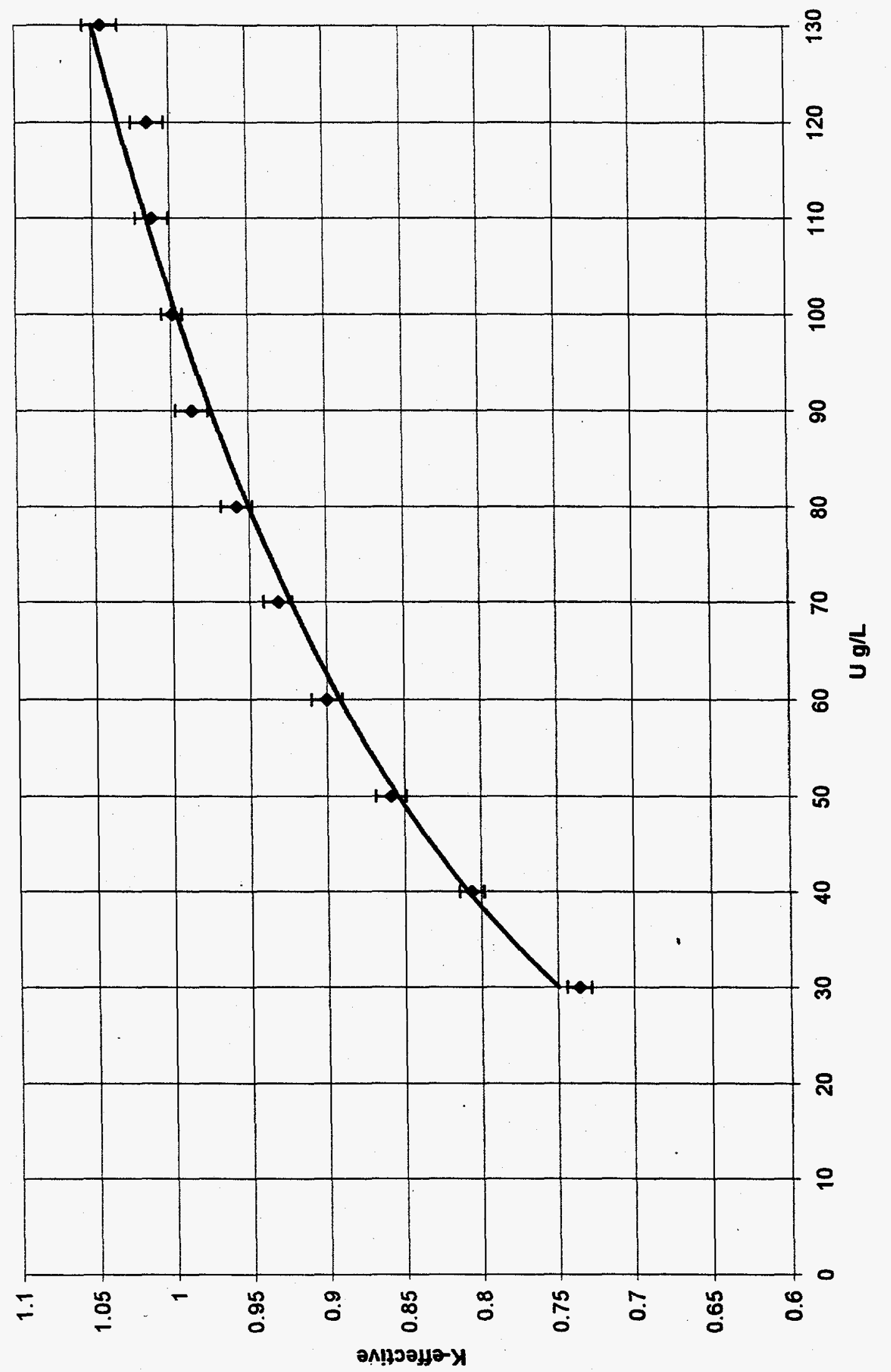

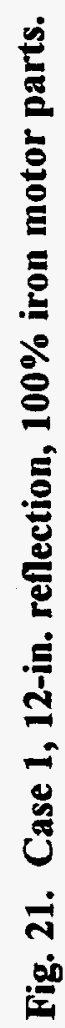




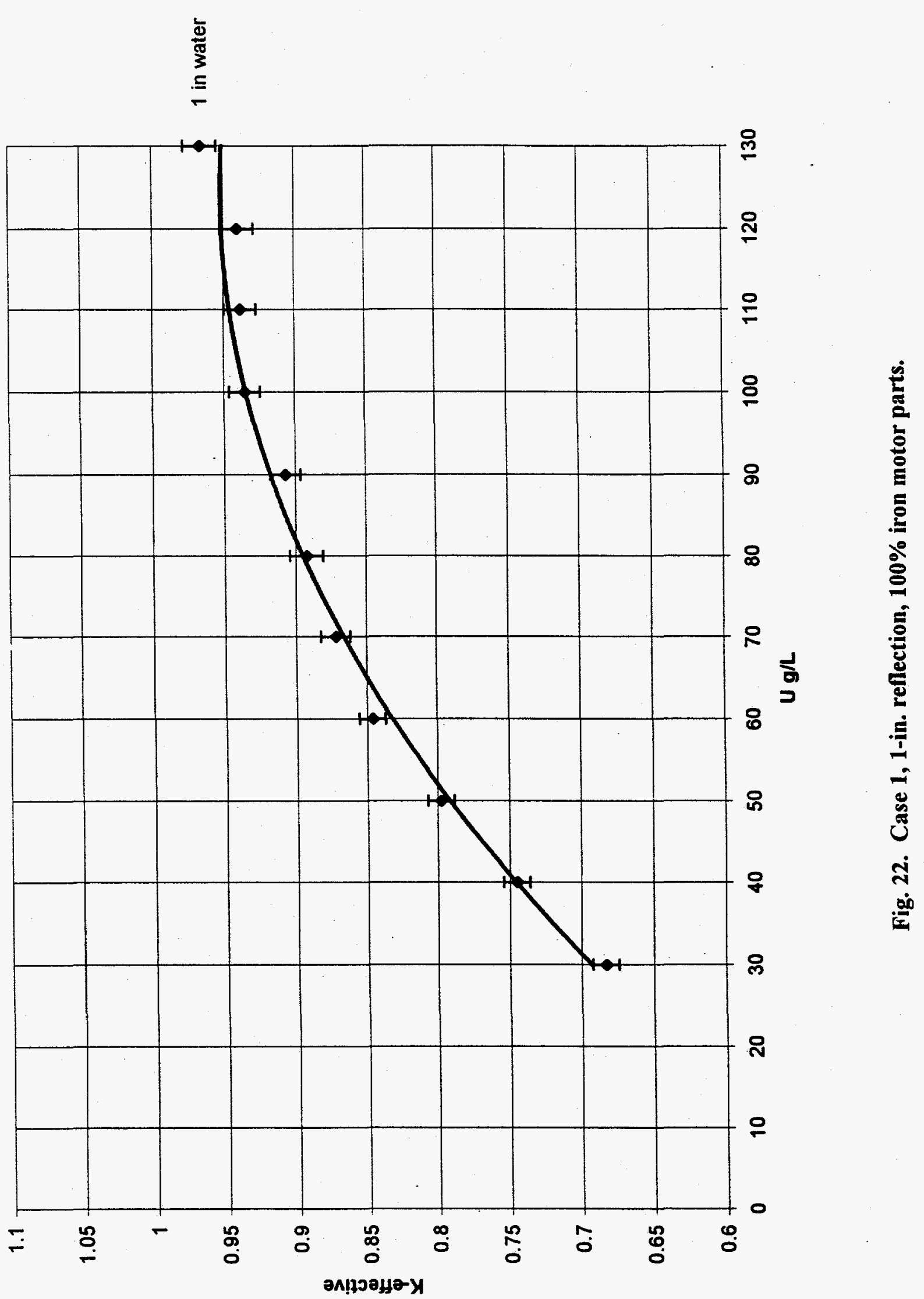


conditions, and below 0.95 for all but the $130 \mathrm{~g} / \mathrm{L}$ condition. The fissile solution fraction in the motor region in Case 1 is $18 \%$.

\section{Case $2.100 \%$ copper motor parts}

For Case 2, iron and copper motor parts (the armature and the field coil) are modeled as consisting only of copper. Aluminum and iron motor parts are again assumed to consist only of aluminum since it is a low neutron absorber. Calculated $k_{\text {eff }}$ are shown in aluminum, since it is a low neutron absorber. Calculated $k_{e f f}$ are shown in Table 5 . The $k_{e f f}$ chosen is the average $k_{\text {eff }}$ which occurs for 103 generations run. Values were obtained for uranium concentrations from 30 to $130 \mathrm{~g} / \mathrm{L}$ at 1 -in. and 12 -in. water reflection. The graphs of these results are shown in Figs. 23 and 24, with error bars indicating the 95\% confidence interval of the data based on two standard deviations. With 12-in. reflection, it again appears that at a concentration of $70 \mathrm{~g} / \mathrm{L}$ of uranium $k_{\text {eff }}$ approaches 0.95 within two standard deviations.

With 1-in. reflection, it appears that at a concentration of $110 \mathrm{~g} / \mathrm{L}$ of uranium $k_{\text {eff }}$ exceeds 0.95 within two standard deviations. In this case, $100 \mathrm{~g} / \mathrm{L}$ is below the $95 \%$ confidence interval of the data. The neutron absorbance cross section at $2200 \mathrm{~m} / \mathrm{s}$ for ${ }^{63} \mathrm{Cu}$ is $3.79 \mathrm{~b}$ as compared with $2.63 \mathrm{~b}$ for ${ }^{56} \mathrm{Fe}$ so the lower $k_{e f f}$ in Case 2 is reasonable.

Table 5. Case $2,100 \%$ copper motor parts

\begin{tabular}{clll||cccc}
\hline \hline & \multicolumn{3}{c|}{ 12-in. reflection } & \multicolumn{4}{c}{ 1-in. reflection } \\
\hline \hline $\mathrm{g} \mathrm{U} / \mathrm{L}$ & \multicolumn{1}{c}{$k_{\text {eff }}$} & \multicolumn{1}{c|}{$2 \sigma$} & $k_{\text {eff }}+2 \sigma$ & $\mathrm{g} \mathrm{U} / \mathrm{L}$ & $k_{\text {eff }}$ & $2 \sigma$ & $k_{\text {eff }}+2 \sigma$ \\
\hline \hline 30 & 0.7304 & 0.0078 & 0.7382 & 30 & 0.6713 & 0.0082 & 0.6795 \\
40 & 0.8119 & 0.0078 & 0.8197 & 40 & 0.7531 & 0.01 & 0.7631 \\
50 & 0.8594 & 0.0092 & 0.8686 & 50 & 0.8034 & 0.0106 & 0.814 \\
60 & 0.903 & 0.01 & 0.913 & 60 & 0.8437 & 0.0098 & 0.8535 \\
70 & 0.931 & 0.011 & 0.942 & 70 & 0.8641 & 0.0108 & 0.8749 \\
80 & 0.9583 & 0.0098 & 0.9681 & 80 & 0.8852 & 0.011 & 0.8962 \\
90 & 0.9895 & 0.0106 & 1.0001 & 90 & 0.9084 & 0.0124 & 0.9208 \\
100 & 0.9983 & 0.0098 & 1.0081 & 100 & 0.9176 & 0.0116 & 0.9292 \\
110 & 1.0207 & 0.011 & 1.0317 & 110 & 0.9445 & 0.0108 & 0.9553 \\
120 & 1.0215 & 0.01 & 1.0315 & 120 & 0.9471 & 0.0114 & 0.9585 \\
130 & 1.0348 & 0.0104 & 1.0452 & 130 & 0.9702 & 0.0102 & 0.9804 \\
\hline \hline
\end{tabular}




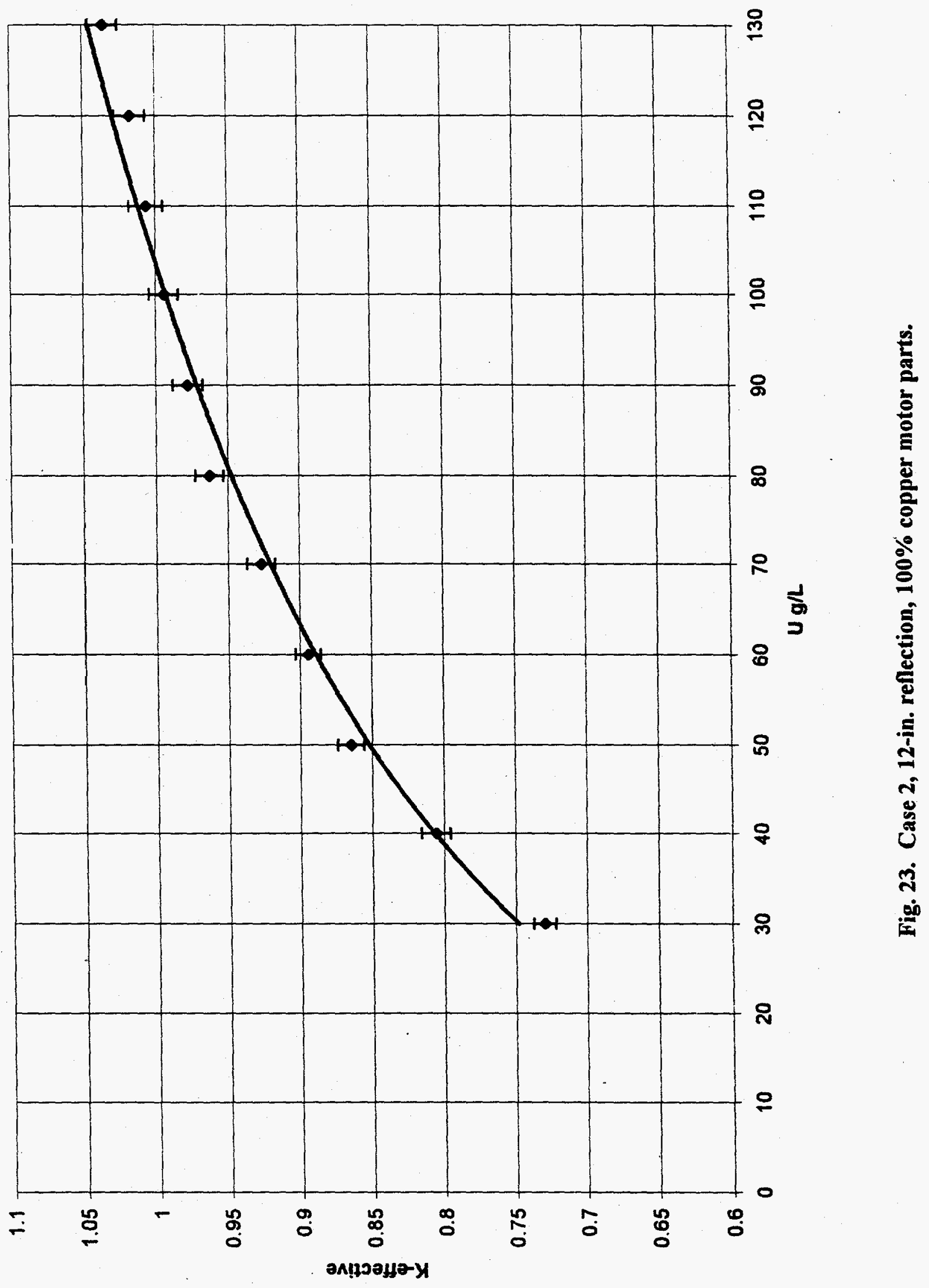




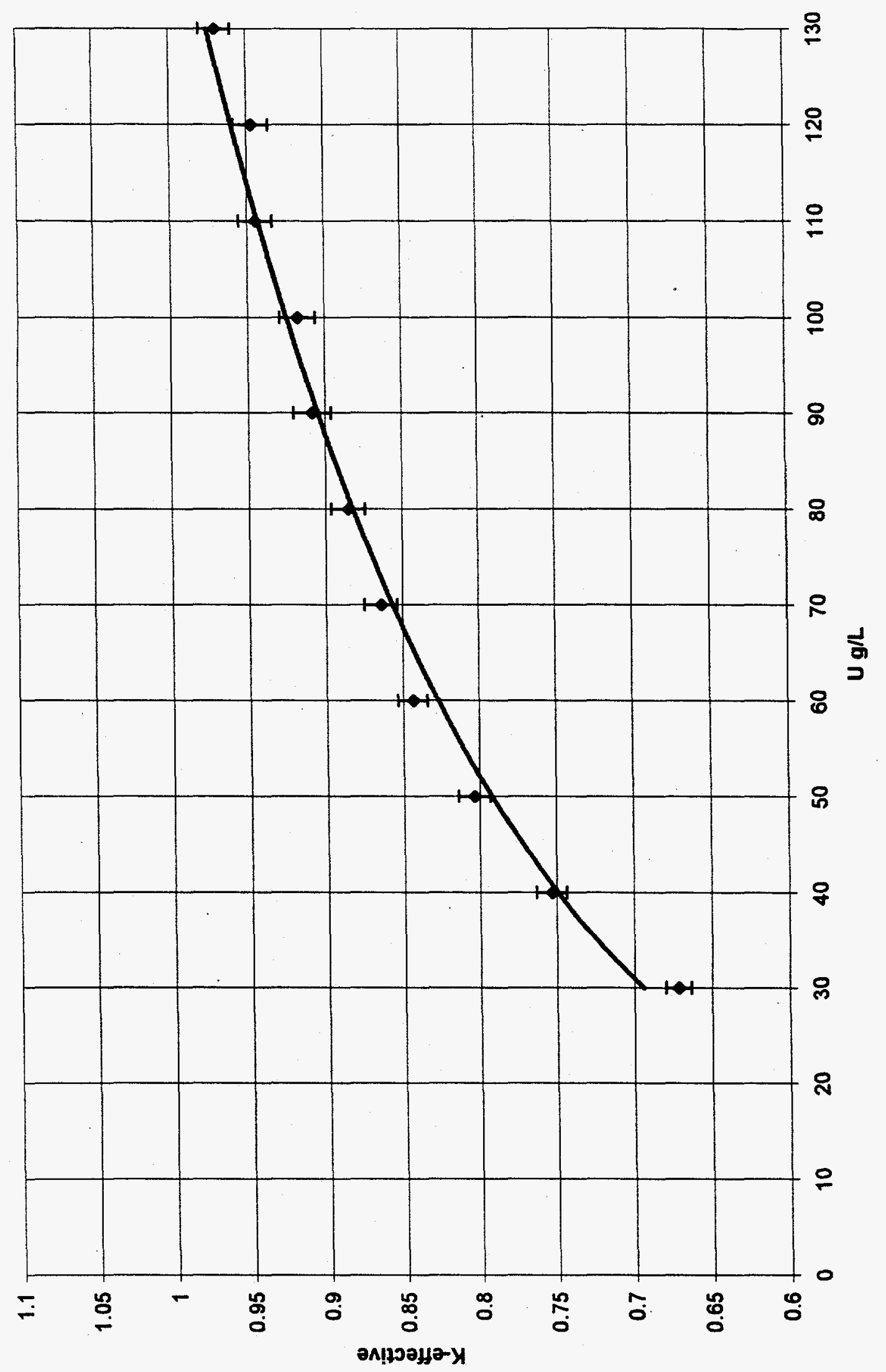

 


\section{Case 3, 50\% copper $150 \%$ iron parts}

For Case 3, iron and copper motor parts (the armature and the field coil) are modeled as a 50:50 mixture of iron and copper. Again, aluminum and iron parts are assumed to consist only of aluminum, since it is a low neutron absorber. Calculated $k_{\text {eff }}$ are shown in Table 6. The $k_{e f f}$ chosen is the average $k_{\text {eff }}$ which occurs for 103 generations run. Values were obtained for uranium concentrations from 30 to $130 \mathrm{~g} / \mathrm{L}$ at 1 -in. and 12 -in. water reflection. The graphs of these results are shown in Figs. 25 and 26, with error bars indicating the 95\% confidence interval of the data based on two standard deviations. With 12-in. reflection, it again appears that at a concentration of $70 \mathrm{~g} / \mathrm{L}$ of uranium $k_{\text {eff }}$ does not reach 0.95 within two standard deviations. With 1-in. reflection, however, it appears that at a concentration of $110 \mathrm{~g} / \mathrm{L}$ of uranium $k_{\text {eff }}$ exceeds 0.95 within two standard deviations. In this case, $100 \mathrm{~g} / \mathrm{L}$ is clearly below the $95 \%$ confidence interval of the data and may be a better figure to choose. The fissile solution fraction in the motor region is $19 \%$ in this case.

Table 6. Case 3, 50\% copper $/ 50 \%$ iron motor parts

\begin{tabular}{rlll||cccc}
\hline \hline \multicolumn{4}{c|}{} & \multicolumn{3}{c|}{ 12-in. reflection } & \multicolumn{5}{c}{ 1-in. reflection } \\
\hline $\mathrm{g} \mathrm{U} / \mathrm{L}$ & \multicolumn{1}{c|}{$k_{\text {eff }}$} & \multicolumn{1}{c|}{$2 \sigma$} & $k_{\text {eff }}+2 \sigma$ & $\mathrm{g} \mathrm{U} / \mathrm{L}$ & $k_{\text {eff }}$ & $2 \sigma$ & $k_{\text {eff }}+2 \sigma$ \\
\hline \hline 30 & 0.7259 & 0.0078 & 0.7345 & 30 & 0.6713 & 0.008 & 0.6793 \\
40 & 0.8002 & 0.0082 & 0.8092 & 40 & 0.7531 & 0.0088 & 0.7619 \\
50 & 0.8658 & 0.0096 & 0.8762 & 50 & 0.8034 & 0.0112 & 0.8146 \\
60 & 0.9046 & 0.0086 & 0.9152 & 60 & 0.8437 & 0.01 & 0.8537 \\
70 & 0.9294 & 0.0096 & 0.9386 & 70 & 0.8641 & 0.011 & 0.8751 \\
80 & 0.9629 & 0.0108 & 0.9725 & 80 & 0.8852 & 0.0106 & 0.8958 \\
90 & 0.9889 & 0.01 & 0.9997 & 90 & 0.9084 & 0.0122 & 0.9206 \\
100 & 0.998 & 0.0116 & 1.0096 & 100 & 0.9176 & 0.0112 & 0.9288 \\
110 & 1.0091 & 0.0104 & 1.0201 & 110 & 0.9445 & 0.012 & 0.9565 \\
120 & 1.0234 & 0.0106 & 1.034 & 120 & 0.9471 & 0.0114 & 0.9585 \\
130 & 1.0386 & 0.0114 & 1.0488 & 130 & 0.9702 & 0.0126 & 0.9828 \\
\hline \hline
\end{tabular}



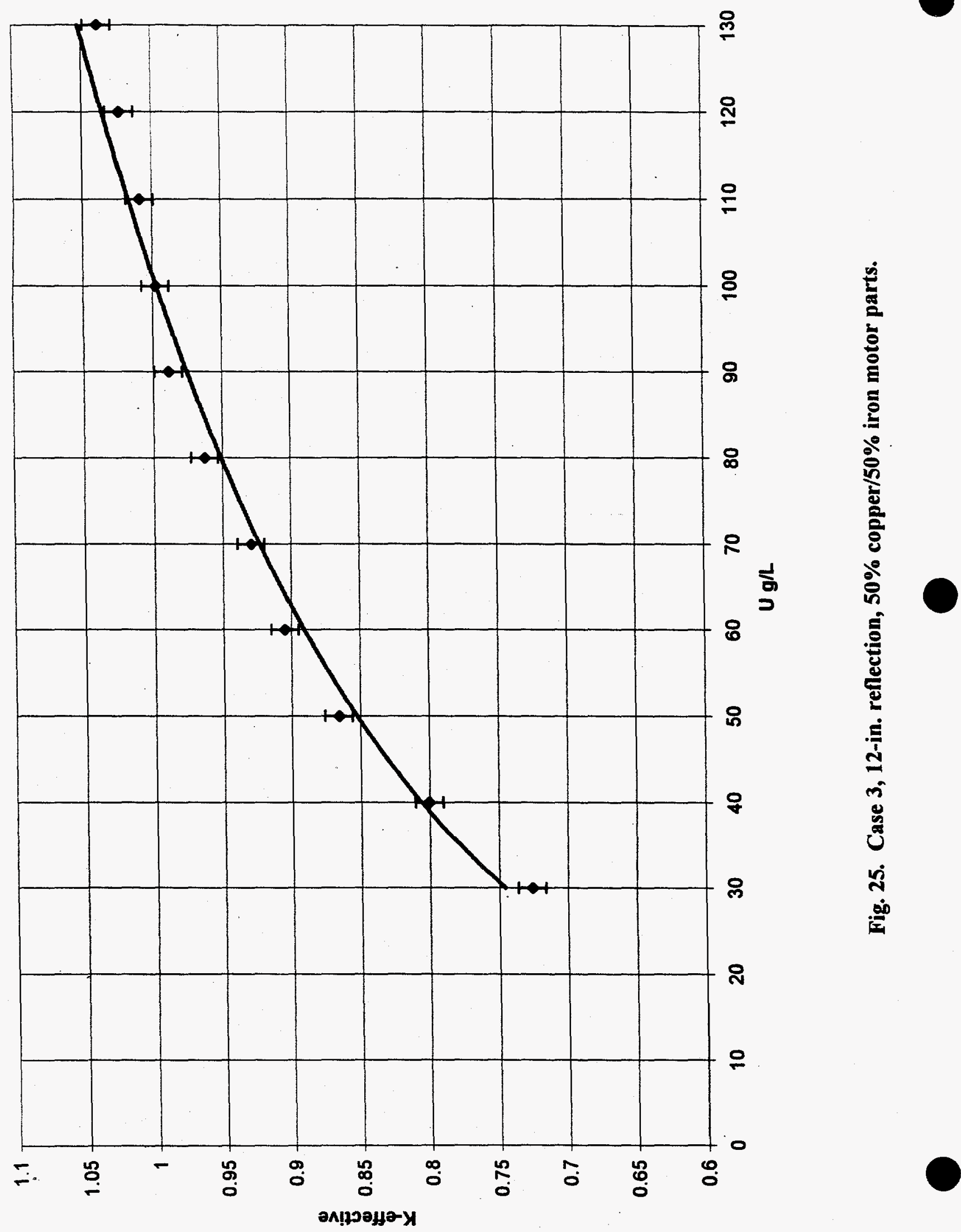


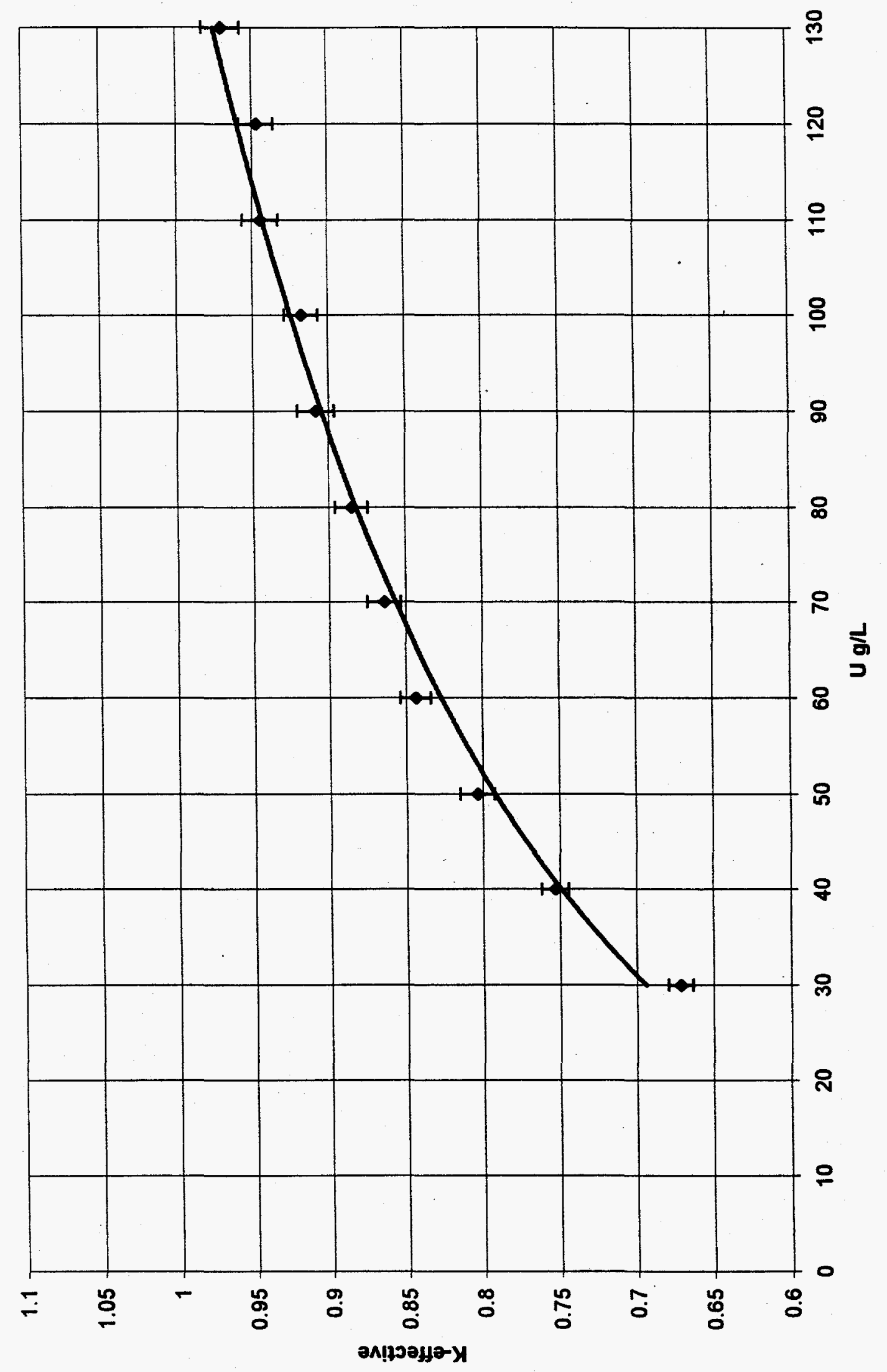

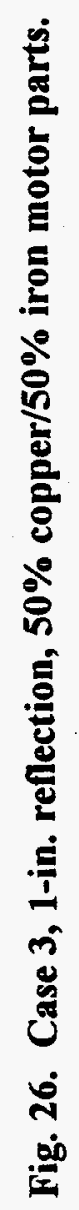




\section{Case 4, motor is entirely void}

For Case 4, all iron, copper, and aluminum parts are removed from the motor assembly and the volume previously occupied by the motor is filled with fissile solution. This case is investigated for reasons of sensitivity analysis and does not represent a realistic case of motor geometry. The $k_{e f f}$ chosen is the average $k_{e f f}$ which occurs for 103 generations run. Values were obtained for uranium concentrations from 30 to $130 \mathrm{~g} / \mathrm{L}$ at 1 -in. and 12 -in. water reflection. The numerical results are shown in Table 7. The graphs of these results are shown in Fig. 27 and 28, with error bars indicating the $95 \%$ confidence interval of the data based on two standard deviations. With 12-in. reflections, it appears that a concentration of $60 \mathrm{~g} / \mathrm{L}$ of uranium $k_{\text {eff }}$ approaches 0.95 within two standard deviations-not greatly different from the previous cases. With 1-in. reflection, it appears that at a concentration of $70 \mathrm{~g} / \mathrm{L}$ of uranium $k_{e f f}$ is close to 0.95 within two standard deviations. This is quite a bit lower concentration than the previous cases and indicates that the unreflected case is much more sensitive to the changes in the fissile solution volume.

Table 7. Case 4, all motor parts are replaced with fissile solution

\begin{tabular}{clll||cccc}
\hline \hline \multicolumn{4}{c|}{ 12-in. reflection } & \multicolumn{4}{c}{ 1-in. reflection } \\
\hline $\mathrm{g} \mathrm{U} / \mathrm{L}$ & \multicolumn{1}{c|}{$k_{\text {eff }}$} & \multicolumn{1}{c|}{$2 \sigma$} & $k_{\text {eff }}+2 \sigma$ & $\mathrm{g} \mathrm{U} / \mathrm{L}$ & \multicolumn{1}{c}{$k_{\text {eff }}$} & $2 \sigma$ & $k_{\text {eff }}+2 \sigma$ \\
\hline \hline 30 & 0.7722 & 0.0082 & 0.7804 & 30 & 0.7214 & 0.009 & 0.7304 \\
40 & 0.843 & 0.0086 & 0.8516 & 40 & 0.7972 & 0.01 & 0.8072 \\
50 & 0.9085 & 0.01 & 0.9185 & 50 & 0.8469 & 0.0098 & 0.8567 \\
60 & 0.9324 & 0.0102 & 0.9426 & 60 & 0.8886 & 0.0116 & 0.9002 \\
70 & 0.9708 & 0.0104 & 0.9812 & 70 & 0.9155 & 0.0096 & 0.9251 \\
80 & 1.0033 & 0.0104 & 1.0137 & 80 & 0.9408 & 0.0096 & 0.9504 \\
90 & 1.0174 & 0.0112 & 1.0286 & 90 & 0.9507 & 0.011 & 0.9617 \\
100 & 1.0303 & 0.0096 & 1.0399 & 100 & 0.9688 & 0.012 & 0.9808 \\
110 & 1.0446 & 0.0112 & 1.0558 & 110 & 0.978 & 0.0108 & 0.9888 \\
120 & 1.0533 & 0.012 & 1.0653 & 120 & 0.9981 & 0.0122 & 1.0103 \\
130 & 1.0739 & 0.0054 & 1.0847 & 130 & 1.0103 & 0.0104 & 1.0207 \\
\hline \hline
\end{tabular}




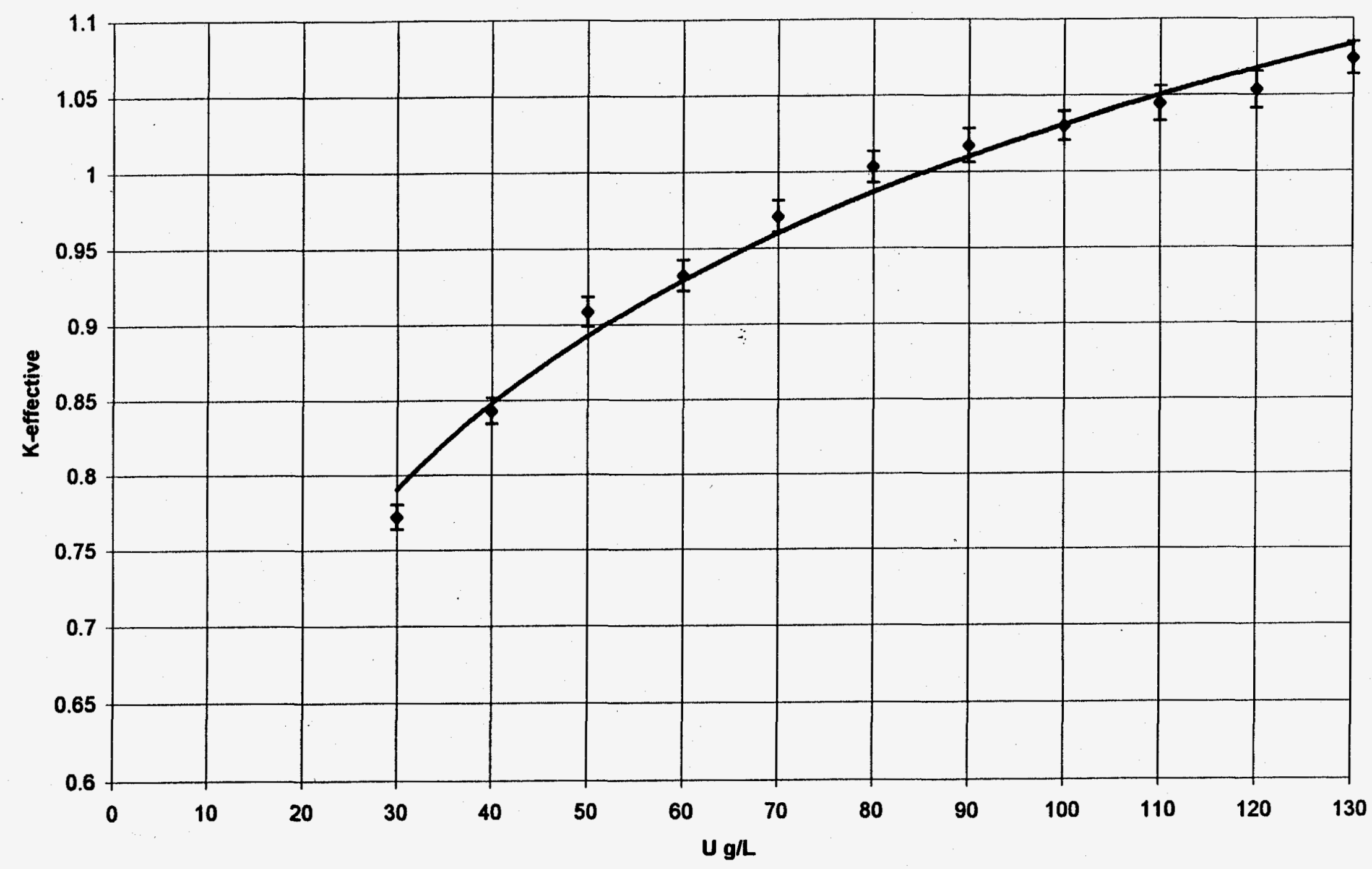

Fig. 27. Case 4, 12-in. reflection, motor parts replaced with fissile solution. 


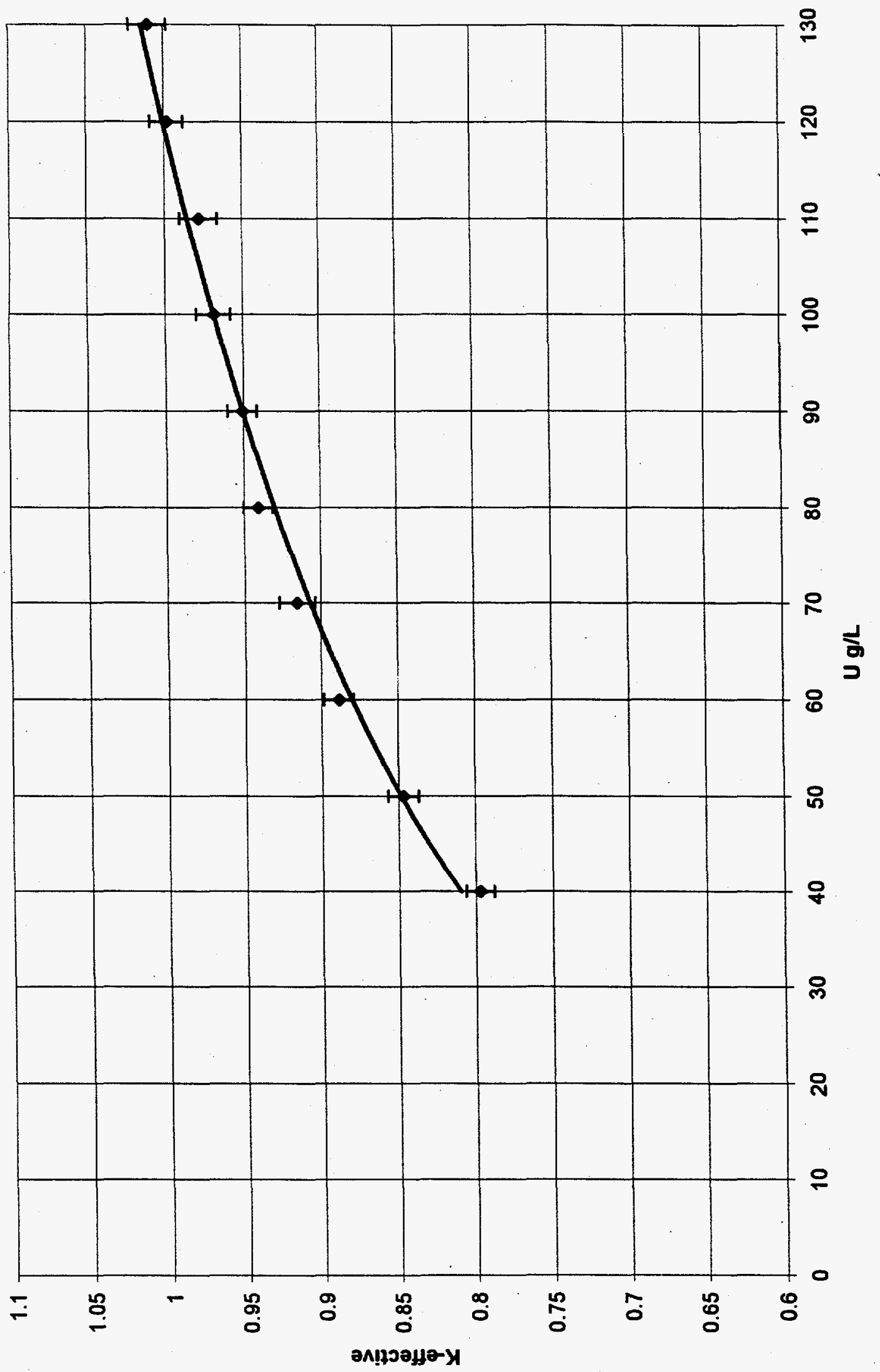

 
Sensitivity analyses were performed around baseline Case $1(100 \%$ motor/fan parts constructed of iron) parameters using varying numbers of fission generations and a fixed number of 300 neutrons per generation with three generations skipped. The case of 12-in. reflection and $100 \mathrm{~g} / \mathrm{L}$ was chosen, in particular, because it produced $k_{e f f}$ values which were very close to 1.0. The $k_{e f f}$ calculated versus number of generations is shown in Fig. 29 with 300 neutrons per generation. We see that the $k_{e f f}$ in general, is fairly constant in value with an increasing number of generations; there is some scatter and a smooth curve is not generated. On the other hand, when the standard deviation, sigma, is plotted against the number of fission generations, as in Fig. 30, a very smooth curve is generated. The standard deviation diminishes asymptotically with an increasing number of generations.

A short analysis was also performed for a case in which the volume occupied by the HEPA filters and other parts was considered not as fissile solution but as volume which was unavailable to contain fissile solution. This analysis was performed for the following reasons. In Cases 1 through 4, the objective was to underestimate the volume occupied by the internal parts of the vacuum cleaner. The purpose there was to make a conservative estimate of the likelihood of a criticality occurring if all the parts of the machine became flooded. Critical concentrations were then calculated on the supposition that the entire machine was flooded. The mass of uranium in the vacuum cleaner was then estimated based on the vacuum cleaner volume. However, the case should be considered in which the mass calculated above is dissolved in solution that cannot reach all parts of the vacuum cleaner, i.e., in which the uranyl fluoride solution containing the above-calculated critical mass is contained in the minimum volume of vacuum cleaner that could be vacant. This involves making the most generous estimate of the occupied motor and filter volume, rather than the most conservative, as was done in Cases 1 through 4. The resulting void volume of the vacuum cleaner was reduced from $20.0 \mathrm{~L}$ to approximately $9.1 \mathrm{~L}$. Therefore, the mass, $1400 \mathrm{~g}$ of uranium, which produced a $k_{e f f}$ of near 0.95 would now be confined to a volume of $9.1 \mathrm{~L}$. The mass confined now to this volume would yield a concentration of $153 \mathrm{~g} / \mathrm{L}$ of uranium. Criticality calculations were again performed assuming the volumes occupied by solution in Cases 1 through 4 now to be occupied by water, and the void volumes remaining to be 


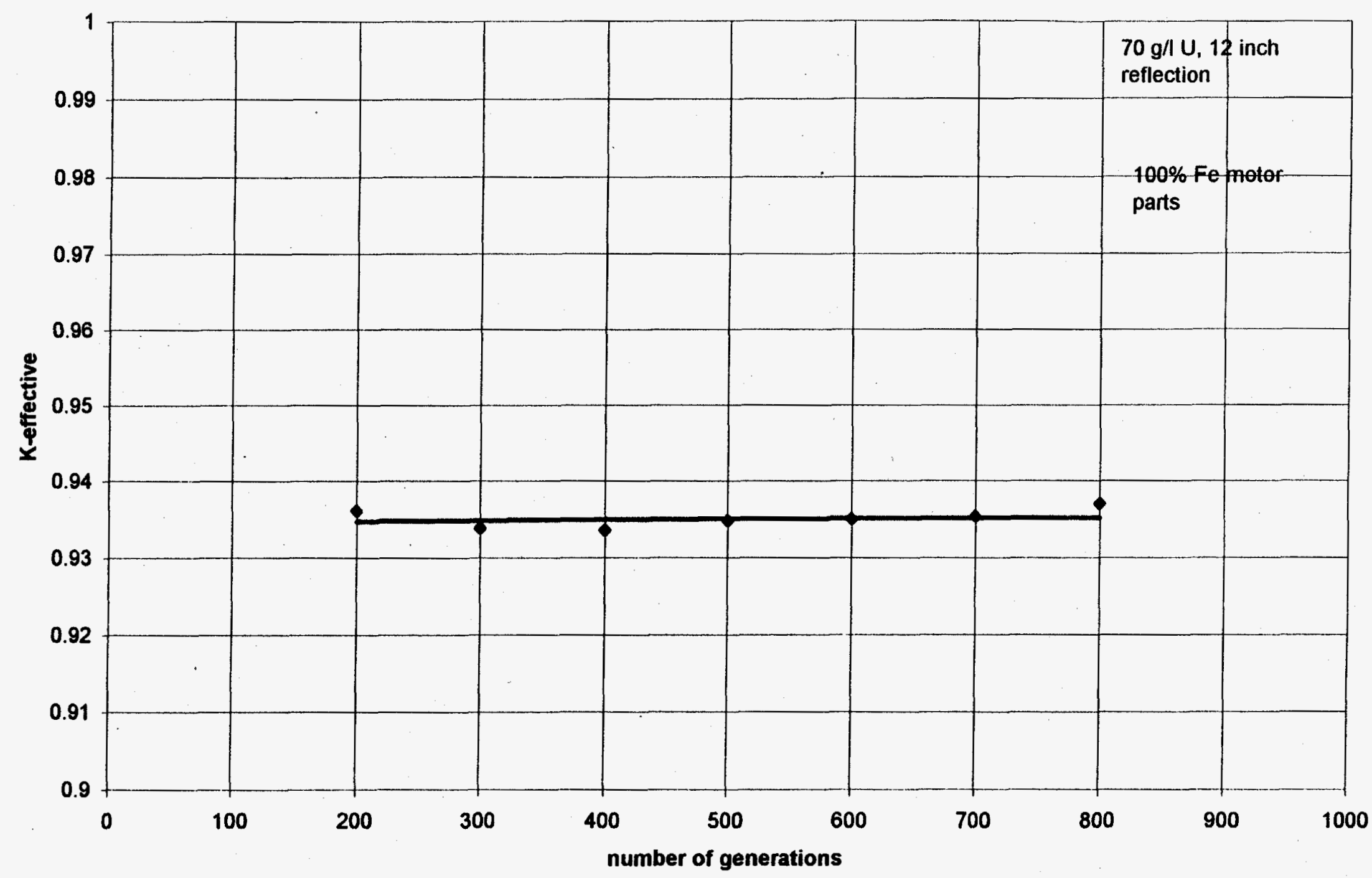

Fig. 29. $K_{e f f}$ Case 1 vs number of generations, 300 neutrons per generation.

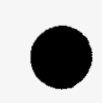




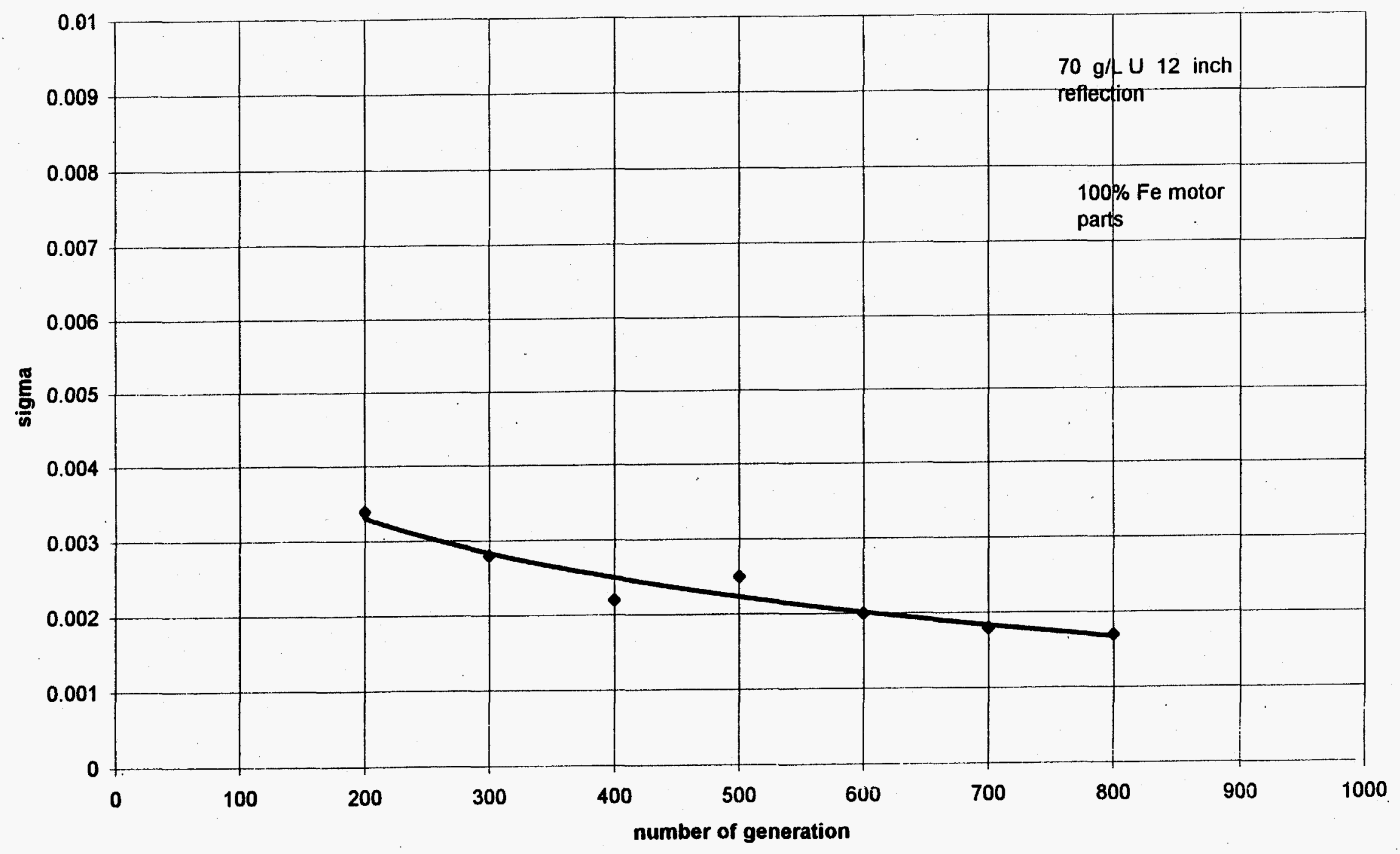

Fig. 30. Standard deviation vs number of generations, Case 1,300 neutrons per generation. 
occupied by uranium solution at $153 \mathrm{~g} / \mathrm{L}$. A $k_{e f f}$ of 0.9115 was calculated at $153 \mathrm{~g} / \mathrm{L}$. Therefore, the previous mass estimates of $1400 \mathrm{~g}$ at $100 \%$ enrichment should be conservative with regard to a criticality arising from this new hypothetical condition.

The effect in Case 1 at 12-in. water reflection on $k_{\text {eff }}$ of diminishing the ${ }^{235} \mathrm{U}$ enrichment level to $20 \%$ was examined and the results are shown in Fig. 31 as a graph of $k_{e f f}$ vs total $U$ concentration in $\mathrm{g} / \mathrm{L}$. It can be readily seen that $k_{e f f}$ does not approach 0.95 within $2 \sigma$ until concentration of $700 \mathrm{~g} / \mathrm{L}$ is reached, about 10 times greater than at $100 \%$ enrichment. The saturation concentration is approximately $1200 \mathrm{~g} \mathrm{U} / \mathrm{L}$ of $\mathrm{UO}_{2} \mathrm{~F}_{2}$ in water according to the SCALE data library. This corresponds to a uranium mass of $28 \mathrm{~kg}$. The results are shown in Table 8.

\subsection{CONCLUSIONS}

A detailed evaluation was made of the geometry, materials of construction, and conditions in which criticality would be produced of a Nilfisk Corp Model GSJ compact vacuum cleaner for a range of uranium concentration. Criticality calculations were performed for three different cases of motor and fan assembly construction at $100 \%$ enrichment. These three cases involved different assumptions about the materials of construction of the motor and fan assembly, since no firm information was available on the exact details of their composition. In Case 1, the baseline case, all parts (which according to the manufacturer could be composed of either iron or copper) were assumed to be composed entirely of iron. In Case 2, the opposite assumption was made that all parts which could be composed of iron or copper were actually composed entirely of copper. In Case 3, it was assumed that the parts were composed of 50\% copper and 50\% iron. A fourth case, in which the motor was hypothetically completely removed, was also considered. This fourth case was to evaluate the sensitivity of the calculations to the motor model. The conclusion was that there is not a significant reactivity effect due to the motor modeling. The motor model utilized in Case 1 is considered conservative and most appropriate for evaluating the safety of the vacuum cleaner. 


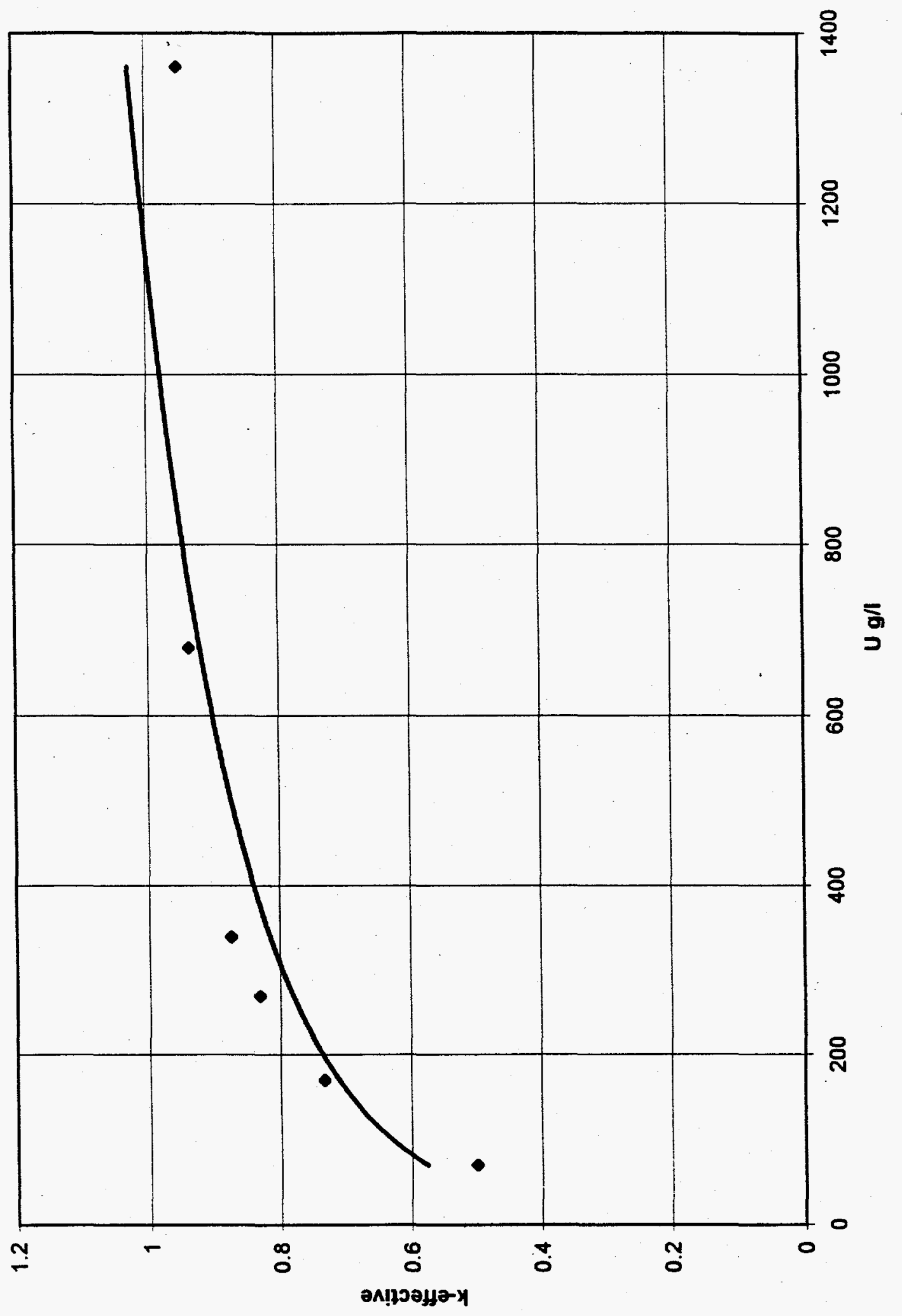

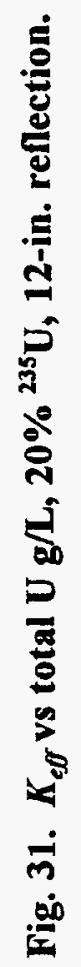


Table 8. $K_{\text {eff }}$ versus total uranium concentration, $20 \%$ enrichment

\begin{tabular}{cl}
\hline \multicolumn{2}{c}{ Baseline Case 1, 12-in. reflection } \\
\hline Uranium, $g / \mathrm{L}$ & $k_{\text {eff }}$ \\
\hline \hline 70 & 0.5 \\
270 & 0.8316 \\
170 & 0.733 \\
340 & 0.8748 \\
680 & 0.9368 \\
$1360^{\circ}$ & 0.95 \\
\hline \hline
\end{tabular}

${ }^{a}$ Probably beyond saturation concentration for $\mathrm{UO}_{2} \mathrm{~F}_{2}$.

The results of the criticality calculations for the three principal cases are shown in the Executive Summary for 12-in. water reflection and $70 \mathrm{~g} \mathrm{U} / \mathrm{L}$ and 1 -in. nominal water reflection and $110 \mathrm{~g} \mathrm{U} / \mathrm{L}$. In the case of 12 -in. water reflection, a $k_{\text {eff }}$ of less than 0.95 within two standard deviations is generated for the three principal cases of motor/fan assembly parts consisting of iron (Case 1), copper (Case 2), and a 50:50 iron/copper mixture (Case 3). This corresponds to a maximum mass of $1400 \mathrm{~g}$ of $\mathrm{U}$ at the $20-\mathrm{L}$ volume that was calculated from the modeled geometry as described in Sect. 3 (compare actual volume, 19.1 L, Appendix E). In the case of 1 -in: water reflection and $100 \mathrm{~g} \mathrm{U} / \mathrm{L}$, the calculated $k_{\text {eff }}$ is very close to 0.95 within two standard deviations in Case 1 and exceeds it in Cases 2 and 3. Therefore, a maximum concentration of $100 \mathrm{~g} / \mathrm{L}$ or a total mass of $2000 \mathrm{~g}$ is recommended in this case. Figure 32 depicts the results of the baseline Case 1 calculations of $k_{e f f}$ vs uranium concentration at 1 -in. and 12 -in. water reflection along with a polynomial curve fit.

An analysis of the vacuum cleaner was made under the assumption that parts which were unlikely to contain solution did not contain any solution. This analysis assumed that the remaining volume of the machine was then filled with a uranyl nitrate solution of 


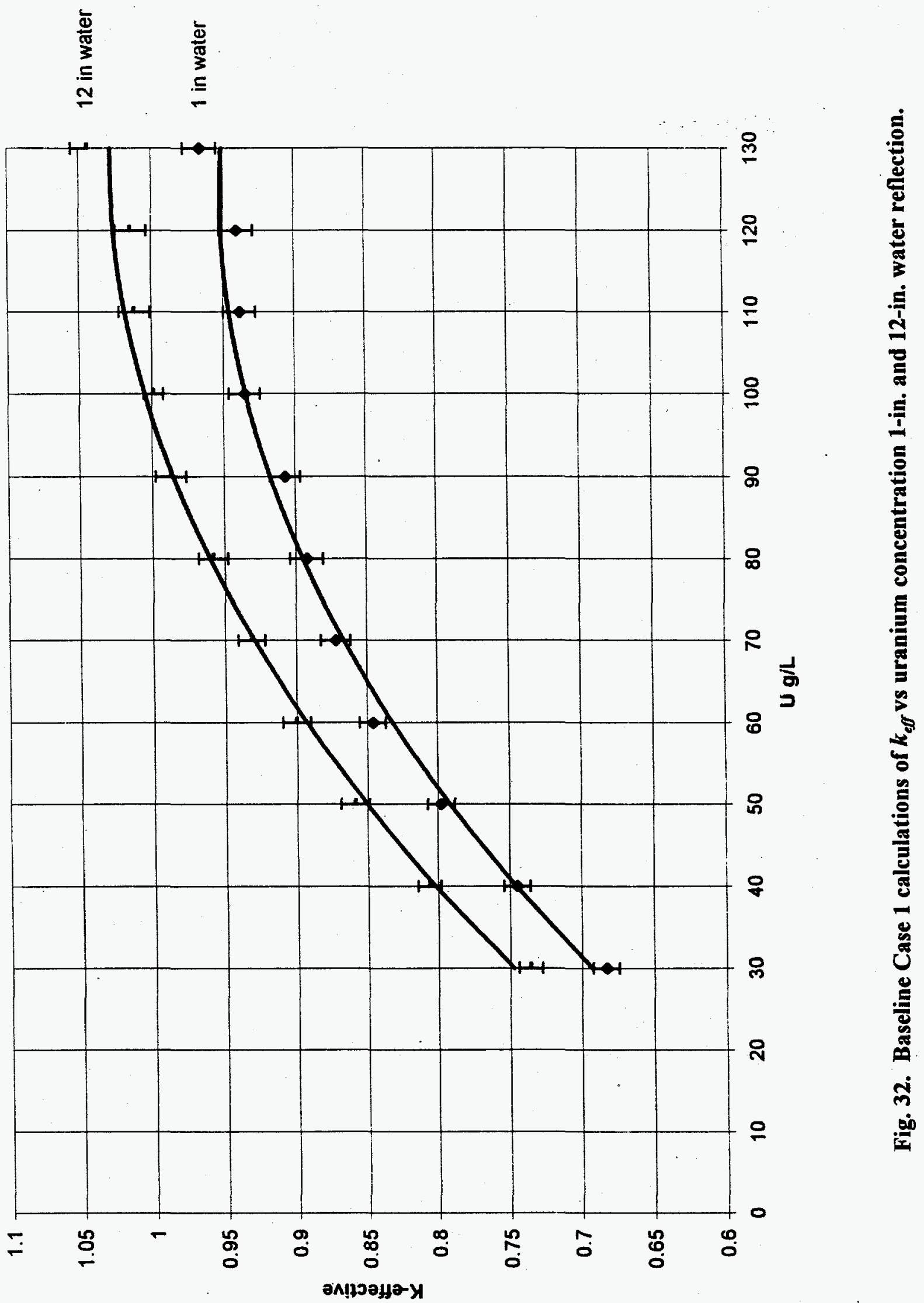


correspondingly greater concentration. The $k_{e f f}$ generated at $1400 \mathrm{~g}$ total $\mathrm{U}$ mass was 0.9115 , safely below 0.95 .

An analysis of the $k_{\text {eff }}$ at an enrichment of $20 \%{ }^{235} \mathrm{U}$ revealed that in the baseline Case 1 at 12 -in. reflection, $k_{e f f}$ did not exceed 0.95 at $680 \mathrm{~g} \mathrm{U} / \mathrm{L}$ (total) and appeared to reach 0.95 only near $1360 \mathrm{~g} \mathrm{U} / \mathrm{L}$ (total) (saturation is below $1300 \mathrm{~g} / \mathrm{L}$ per KENO). A sample output from the baseline Case 1, $70 \mathrm{~g}$ U/L uranium, 12-in. reflection is provided in Appendix B.

\section{CODE VALIDATION}

Section 3.1 describes the calculational method. In summary, the SCALE computer code was used in this nuclear criticality evaluation. The CSAS25 control sequence of SCALE and the 27 energy group library, based on ENDF/B-IV cross section, were used for all computations. The CSAS25 control sequence activates modules BONAMI-S, NITAWL-S and KENO V.a. Scoping sensitivity calculations were done on a personal computer with an unvalidated version of SCALE-PC. Key calculations at critical conditions were done with a validated version of the SCALE 4.1 code and KENO V.a ran on the K-25 Site IBM 3090 main frame computer. Reference 6 documents the validation.

The SCALE 4.1/KENO V.a and SCALE 27 group cross sections were validated for the IBM 3090 (MK25B) mainframe at the Oak Ridge K-25 Site by comparing calculated predictions to 245 critical experiment results at $k_{e f f}=1.0$. The validation demonstrated the functionality and ability of the SCALE codes and cross section input data to accurately calculate critical experiments results. A statistical analysis was performed and a lower $k_{\text {eff }}$ acceptance criteria of $k_{\text {eff }}+2 \sigma<0.9605$ was established. That is, a calculated $k_{e f f}+2 \sigma<0.9605$ may be considered safely subcritical. Because of the broad range of enrichment and moderation considered in this analysis of the vacuum cleaner, an additional $1 \%$ margin was included for this work. Thus, a system with a calculated $k_{e f f}+2 \sigma>0.95$ is considered unsafe and may be critical. The SCALE mainframe and personal computer (PC) code results are shown together in Fig. 33. The calculated $k_{\text {eff }}$ agree to within two standard 'deviations. Code validations were provided by running the PC source codes for Cases 1,2 , 

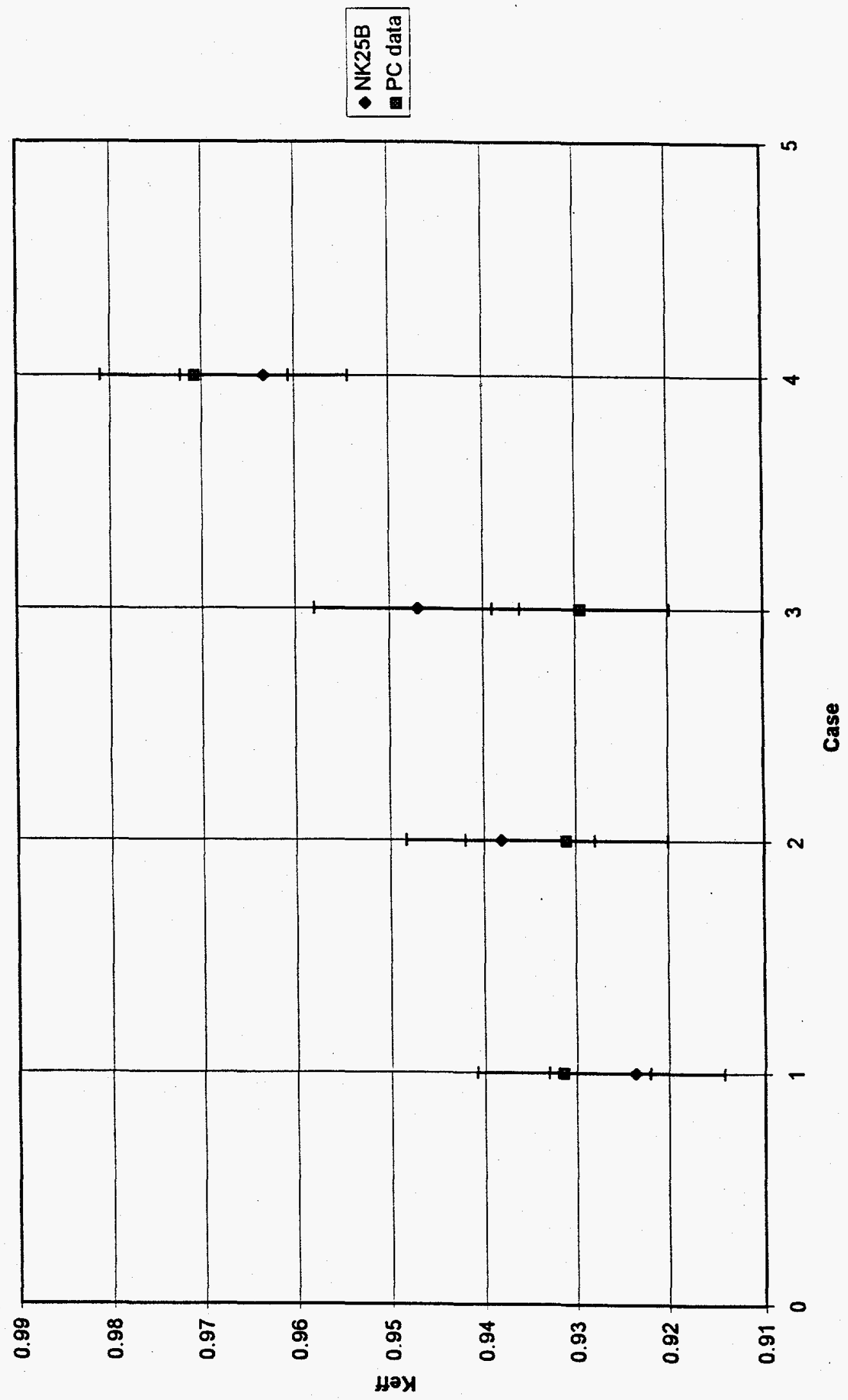

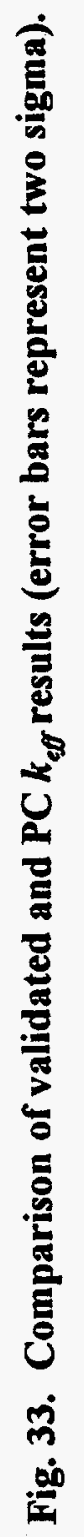


and 3 at fissile uranium concentrations of $70 \mathrm{~g} \mathrm{U} / \mathrm{L}$ on the NK25B validated mainframe computer. The results are contained in Table 9 and, as will be observed, fall in most cases near to within two sigma of the PC scoping calculations. This is further justification for the additional $\approx 1 \%$ safety margin taken on the $k_{e f f}$ acceptance criterium. There were minor errors in the codes executed in these cases, which have since been corrected, and should not affect the bias of the results.

Table 9. Comparison of validated and $\mathrm{PC} k_{e f f}$ results

\begin{tabular}{|c|c|c|c|c|c|}
\hline \multirow{2}{*}{ Case } & \multirow{2}{*}{ Runs } & \multicolumn{2}{|c|}{ NK25B data } & \multicolumn{2}{|c|}{ PC data } \\
\hline & & $k_{\text {eff }}$ & $\sigma$ & $k_{e f f}$ & $\sigma$ \\
\hline 1 & C70R2 & $0.9236^{a}$ & \pm 0.0047 & 0.9314 & \pm 0.0047 \\
\hline 2 & $\mathrm{C} 27 \mathrm{R} 1$ & 0.9381 & \pm 0.0051 & 0.9310 & \pm 0.0055 \\
\hline 3 & C37R1 & 0.9470 & \pm 0.0055 & 0.9294 & \pm 0.0048 \\
\hline 4 & C47RD & 0.9633 & \pm 0.0045 & 0.9708 & \pm 0.0051 \\
\hline
\end{tabular}

${ }^{a}$ There was a slight error in the densities of aluminum and iron in this calculation of the order of $3 \%$ and they were not recalculated. 


\section{REFERENCES}

1. RISC Computer Code Collection, SCALE-PC Modular Code System for Performing Criticality Safety Analyses for Licensing Evaluation, Version 4.1, Part 1, CCC-619, Oak Ridge National Laboratory, Oak Ridge, Tennessee.

2. Nilfisk of America, Inc., Malvern, Pennsylvania, Nilfisk Compact Vac Product Literature, March 1996.

3. Dimento, V., Nilfisk of America, Inc., Malvern, Pennsylvania, Facsimile Communication to J. Shor, July 22, 1996, Oak Ridge National Laboratory, Oak Ridge, Tennessee.

4. Jordan, W. C., Calculational Criticality Analyses of 10- and 20-MW UF 6 Freezer/Sublimer Vessels, ORNL/CSD/TM-288, Martin Marietta Energy Systems, Inc., Oak Ridge National Laboratory, Oak Ridge, Tennessee, February 1993.

5. C. A. Sweet, "Criticality Safety Analysis of a Vacuum Cleaner for General High Enriched Uranium Cleanup Work," unpublished report, Lockheed Martin Energy Systems, Inc., July 28, 1993.

6. Lee, B. L., Jr. and D. M. D'Aquila, Validation of Nuclear Criticality Safety Software and 27 Energy Group ENDF/B-IV Cross Section, POEF-T-3636, Rev. 1, Portsmouth Gaseous Diffusion Plant, Portsmouth, Ohio (January 1996). 
APPENDIX A. MODELING CALCULATIONS

A-1 
$\bullet$

-

- 


\section{APPENDIX A. MODELING CALCULATIONS}

\section{Nilfisk data:}

1. Armature

2. Field coil

3. Fan assembly

$1.25 \mathrm{lbs}$

$$
567.5 \mathrm{~g}
$$

$908.0 \mathrm{~g}$

$2.00 \mathrm{lbs}$

$567.5 \mathrm{~g}$

$\mathrm{Cu} / \mathrm{Fe}$

$\Delta_{\mathrm{Fe}}=7.86 \mathrm{~g}$

$1.25 \mathrm{lbs}$

$$
1021.0 \mathrm{~g}
$$

$\mathrm{Cu} / \mathrm{Fe}$

$\Delta_{\mathrm{Cu}}=8.96 \mathrm{~g}$

4. Motor assembly

$2.25 \mathrm{lbs}$

Al

$\mathrm{A} 1 / \mathrm{Fe}$

Total motor volume:

6 in. $\times 1.75^{2} \pi=57.7$ in. $^{3}=945 \mathrm{cc}$

$\mathrm{h} \times \mathrm{r}^{2} \pi$

\section{Case 1, Baseline}

Assume Parts 1 and 2 are entirely of iron. Parts 3 and 4 are entirely of aluminum. Then, we have $1484 \mathrm{~g}$ of iron, $1589 \mathrm{~g}$ of aluminum. M.W. $=55.8$, i.e., $189 \mathrm{cc}$ of iron $+588 \mathrm{cc}$ of aluminum $=777$ total occupied volume and $168 \mathrm{cc}$ void volume or $\sim 18 \%$.

Consider smeared densities:

Thus, rho molar of iron $=0.028$; rho atom $=0.017$ atoms $/ \mathrm{b} \cdot \mathrm{cm}^{2}$, and aluminum $=0.06228$; rho atom $=0.0375$ atoms $/ \mathrm{b} \cdot \mathrm{cm}^{2}$.

$$
\text { where, } 6.022 \times \frac{10^{23} \text { atoms }}{\text { mole }} \quad 1 \times \frac{10^{-24} \mathrm{~b}}{\mathrm{~cm}^{2}}
$$

\section{Case 2}

Assume Parts 1 and 2 are all copper, Parts 3 and 4 are entirely aluminum. Then we have $1484 \mathrm{~g}$ of copper and $1589 \mathrm{~g}$ of aluminum.

$$
\begin{aligned}
& \Delta \text { atomic } \quad \mathrm{Cu}=1484 / 63.54 \cdot 945(0.622)=0.0148 \\
& \Delta \text { atomic } \quad \mathrm{Al}=0.0375 \text { again } \\
& \text { Volume of copper }=1484 / 8.96=165 \mathrm{cc} \\
& \text { Volume of aluminum }=588 \mathrm{cc} \\
& \text { Total volume }=754 \mathrm{cc} \\
& \text { Void volume }=191 \mathrm{cc} \text { or } 20 \%
\end{aligned}
$$




\section{Case 3}

50:50 mixture of copper and iron

\begin{tabular}{ccc} 
Now, we have & $742 \mathrm{~g}$ copper & 82.8 \\
& $742 \mathrm{~g}$ iron & 97.4 \\
& $1589 \mathrm{~g}$ aluminum & $588 \mathrm{cc}$ \\
\hline
\end{tabular}

Therefore, $\Delta$ atomic copper $=0.00744$

$\Delta$ atomic iron $=0.0084$

$\Delta$ atomic aluminum $=0.0375$. 
APPENDIX B. CRITICALITY SAFETY CALCULATION CHECK-OFF SHEET

B-1 
○

-

- 


\section{APPENDIX B}

\section{CRITICALITY SAFEIY CALCULATION CHECK-OFF SHEET}

MCS Calculations for the K-25Site Uacumen P/eanes K/ER -314

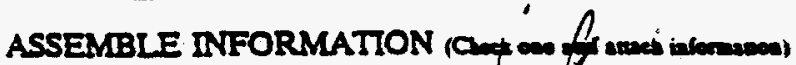

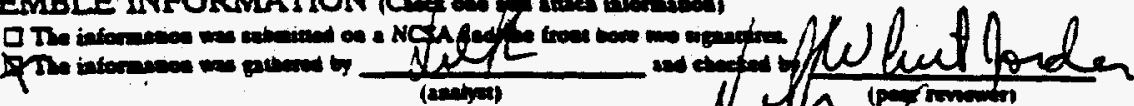

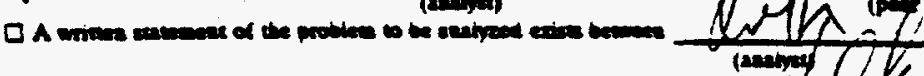

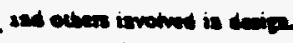

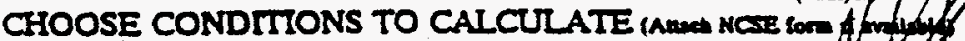

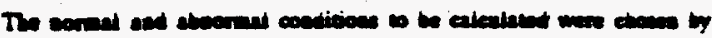

ogenocen ate

ap/n

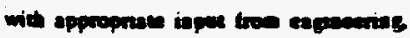

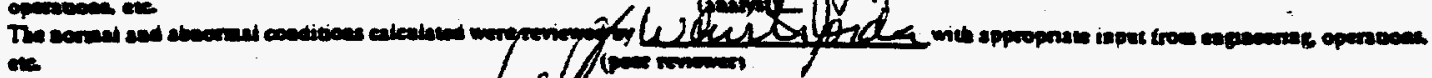

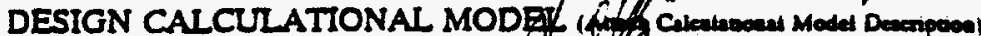

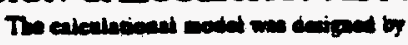

fixing

The

(1) 9 restion (B)

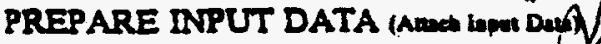

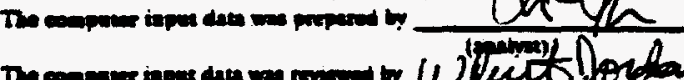

opien

COMPUTE

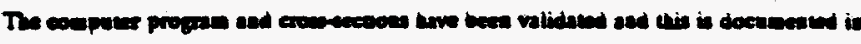

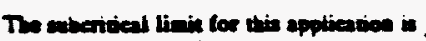

$$
\frac{1404}{(20)}
$$

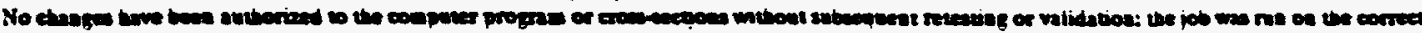

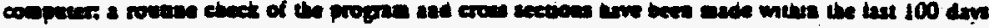

INTERPRET RESTLIS (Anath Remin)

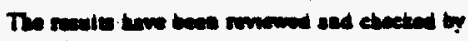

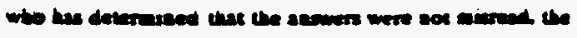
tpens romenen

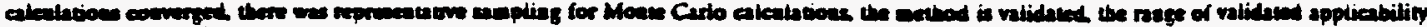

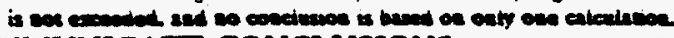

COMMUNICATE CONCLUSIONS (Amat Cometwon)

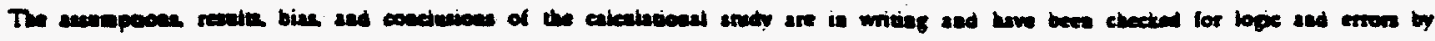

REVTEW (Amech Rniow

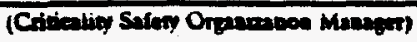

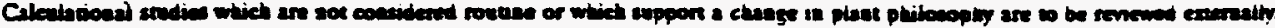

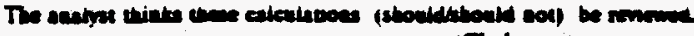

(Cirte enos

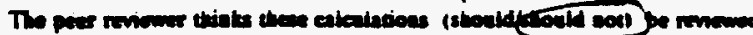

$$
\text { (Criarom }
$$

wen $1 / 2 / 97$

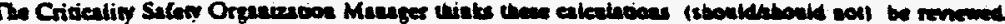

(Circle Oed)

NOTE: Oes or ane Sbould" voves require the renew. 
APPENDIX C. KENO-CODE-GENERATED MAP OF VACUUM CLEANER

C-1 
-

-

- 
C-3

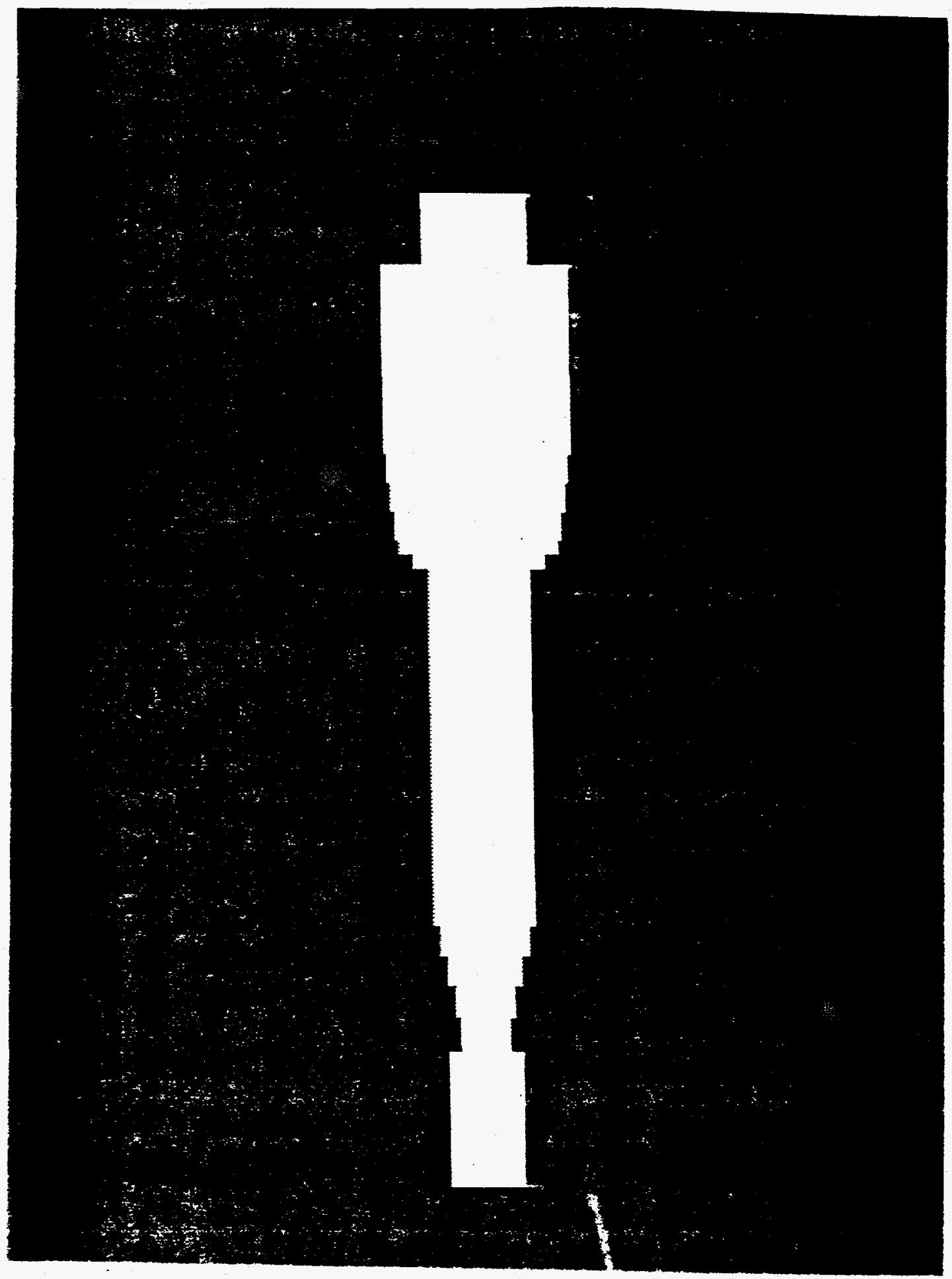

Fig. C-1. KENO-Code-generated map of vacuum cleaner. 
APPENDIX D. VOLUMES OF UNITS 1 THROUGH 18, CALCULATED BY EXCEL AND KENO

D-1 
-

-

- 
D-3

Calculated volumes of individual units of model

\begin{tabular}{cccc}
\hline Unit & Radius & Height & Volume \\
\hline 1 & 4.445 & 17.15 & $1,063.989$ \\
2 & 2.857 & 4.127 & 105.7754 \\
3 & 3.505 & 3.81 & 146.9707 \\
4 & 4.39 & 3.81 & 230.5598 \\
5 & 5.289 & 3.81 & 334.6584 \\
6 & 6.18 & 3.81 & 456.911 \\
7 & 6.185 & 40.64 & $4,881.606$ \\
8 & 8 & 1.74 & 349.6704 \\
9 & 9.65 & 1.74 & 508.7841 \\
10 & 10.1 & 3.58 & $1,146.715$ \\
11 & 10.55 & 3.58 & $1,251.174$ \\
12 & 11 & 3.58 & $1,360.185$ \\
13 & 11.45 & 3.58 & $1,473.749$ \\
14 & 11.45 & 3.48 & $1,432.583$ \\
15 & 8.89 & 1.27 & 315.1642 \\
16 & 8.89 & 9.22 & $1,716.032$ \\
17 & 11.45 & 6.02 & $2,104.722$ \\
18 & 6.35 & 8.89 & $1,125.586$ \\
& & & \\
Total & & & $20,004.84$ \\
\hline & & & \\
\hline
\end{tabular}


APPENDIX E. MATH CAD ESTIMATES OF ACTUAL VACUUM CLEANER MINIMUM VOLUME

E-1 
-
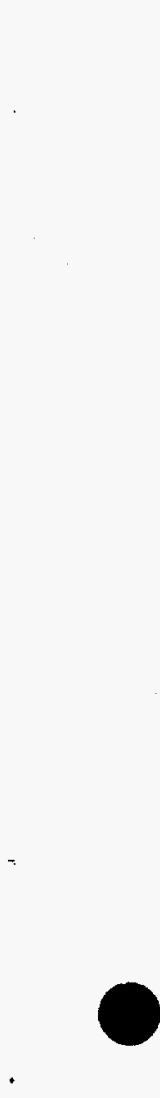

- 


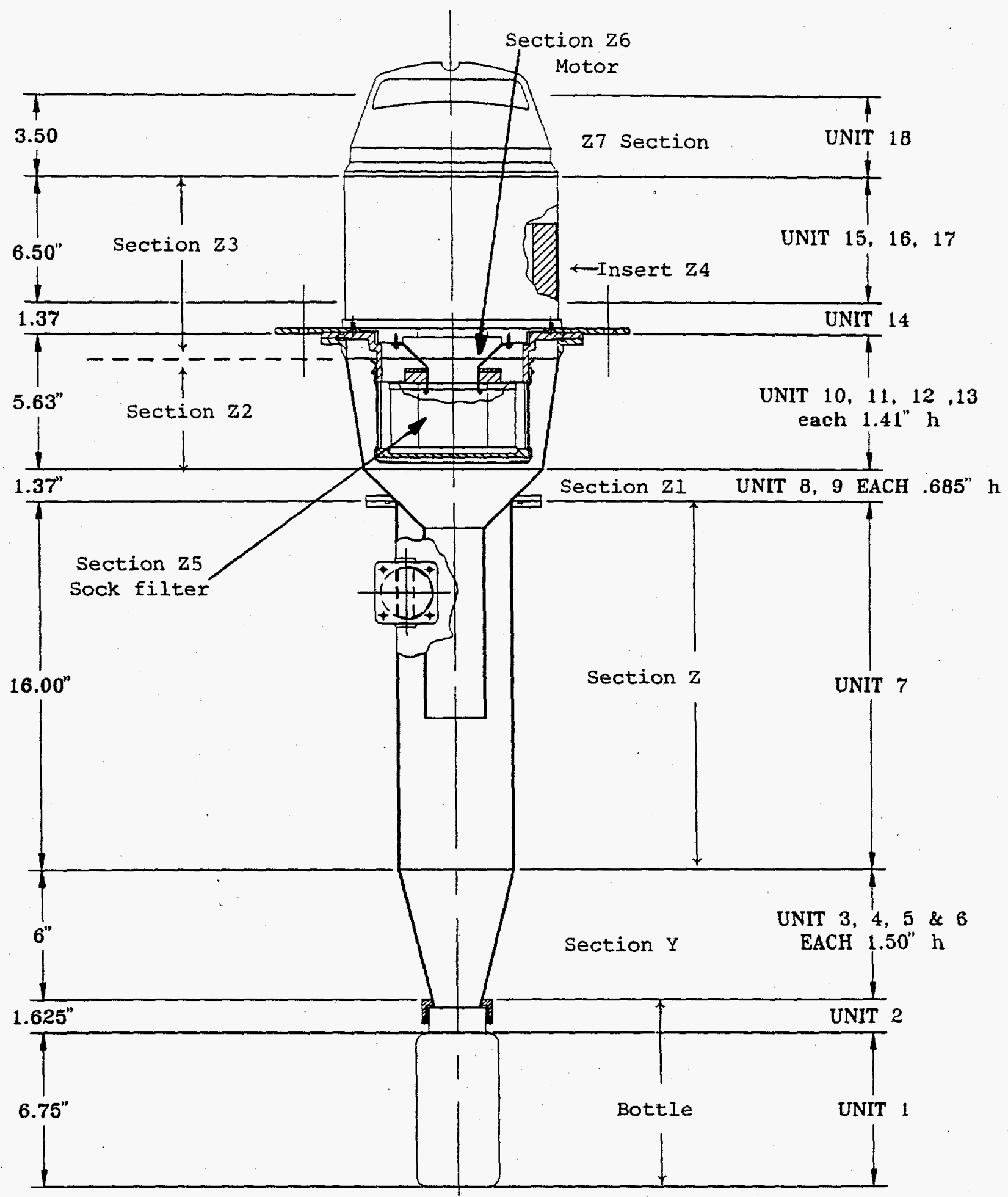

Fig. E.1. Division of vacuum cleaner into sections to calculate actual volumes. 


\section{E-4}
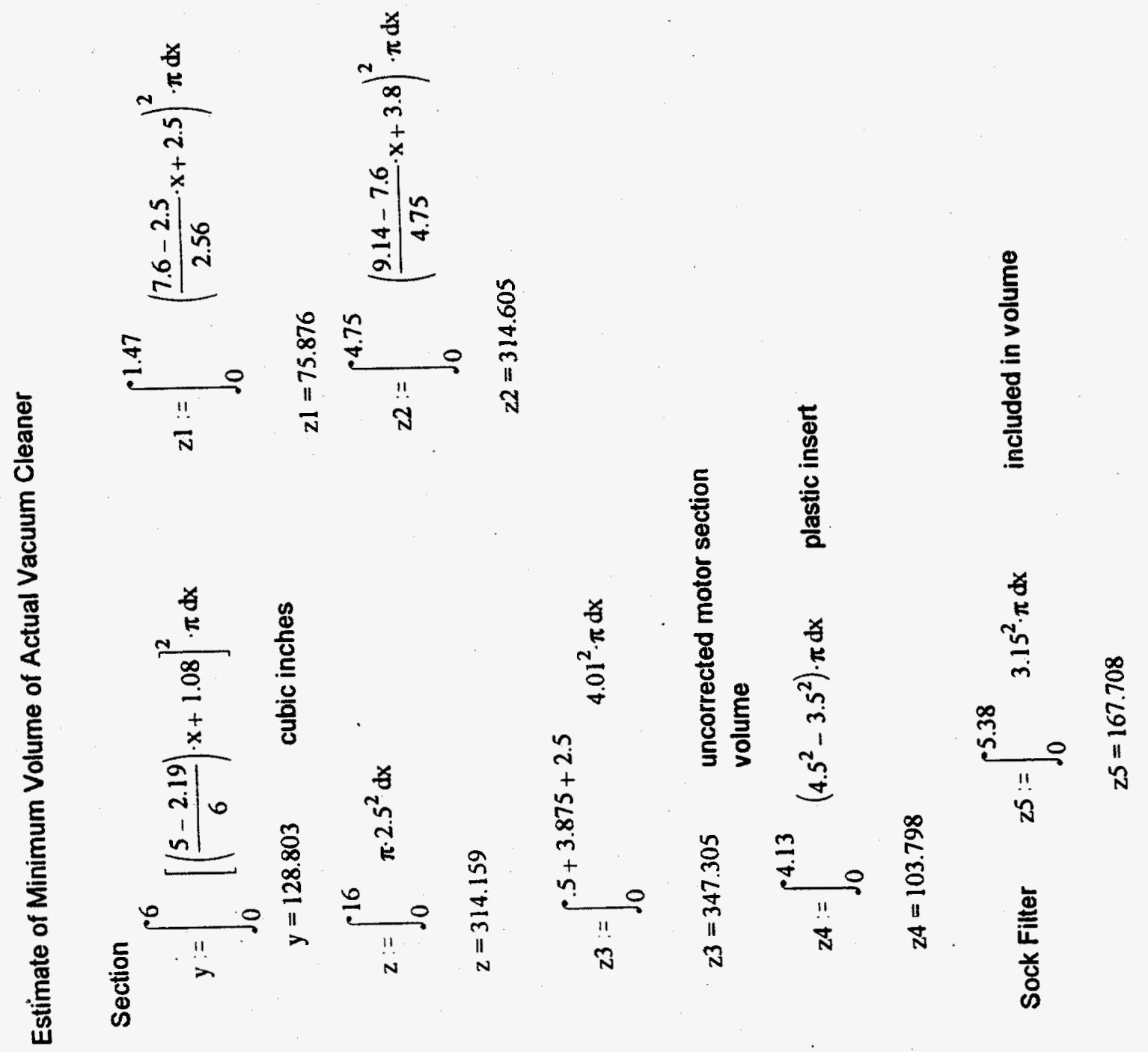
E-5
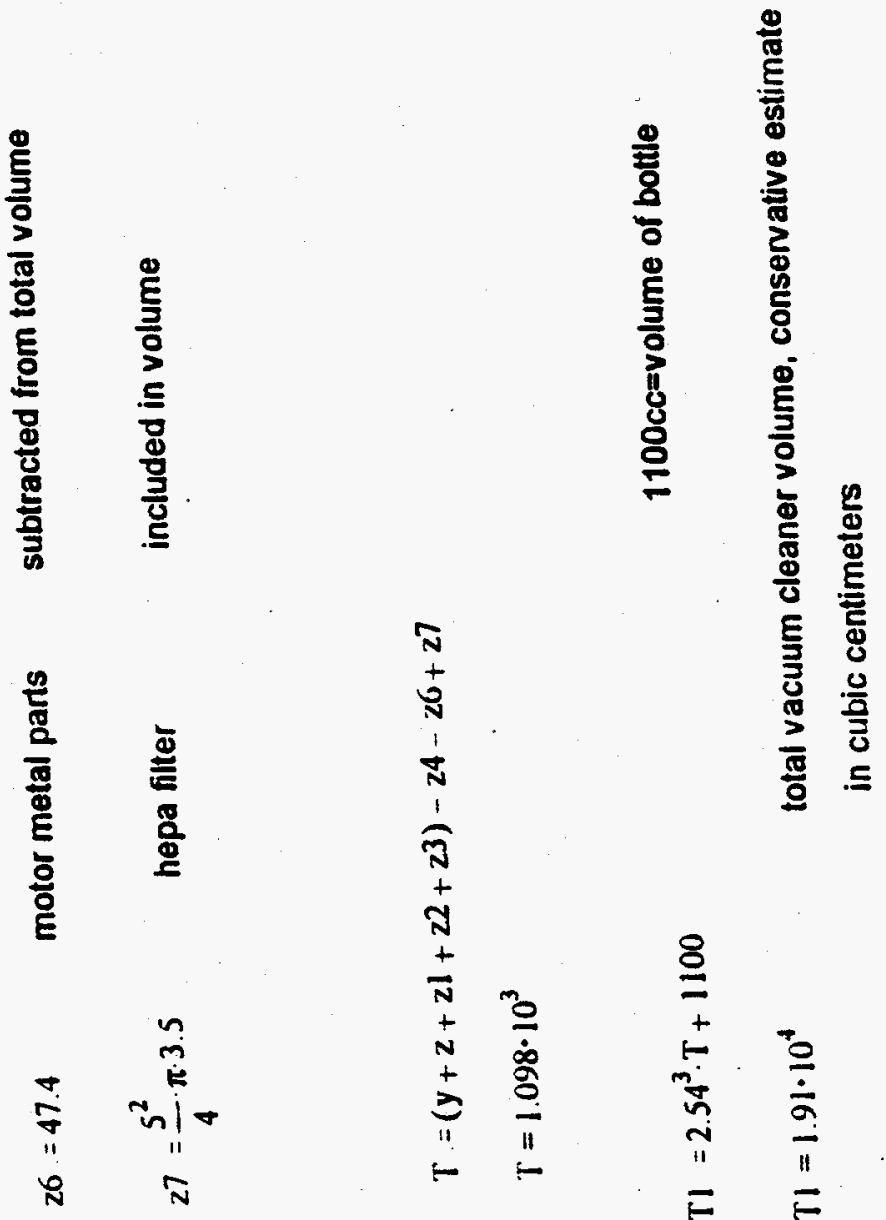
APPENDIX F. SAMPLE OF SCALE OUTPUT CASE 1, $70 \mathrm{~g} / \mathrm{L}, 12$-in. WATER REFLECTION 
-

-

- 


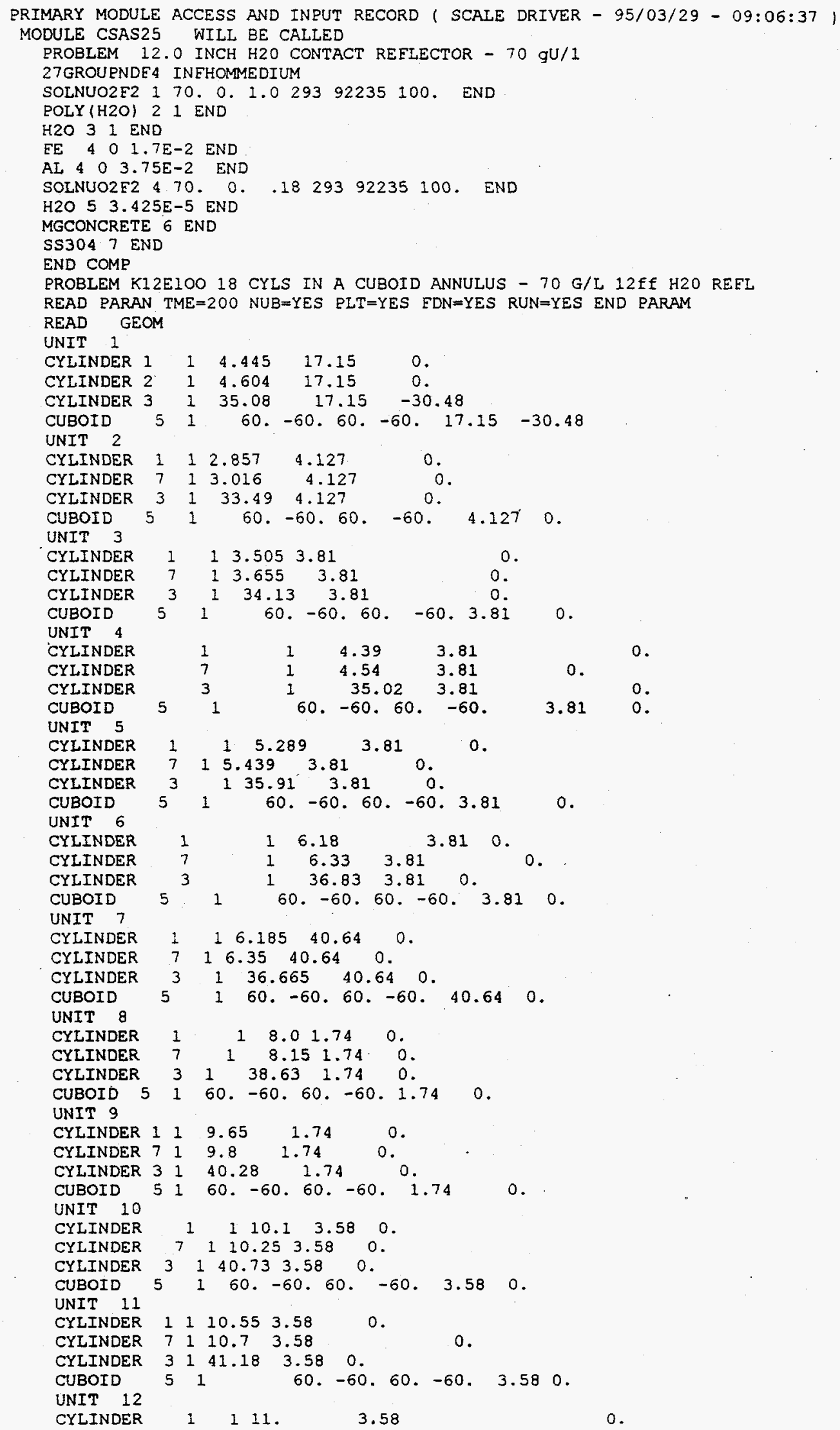




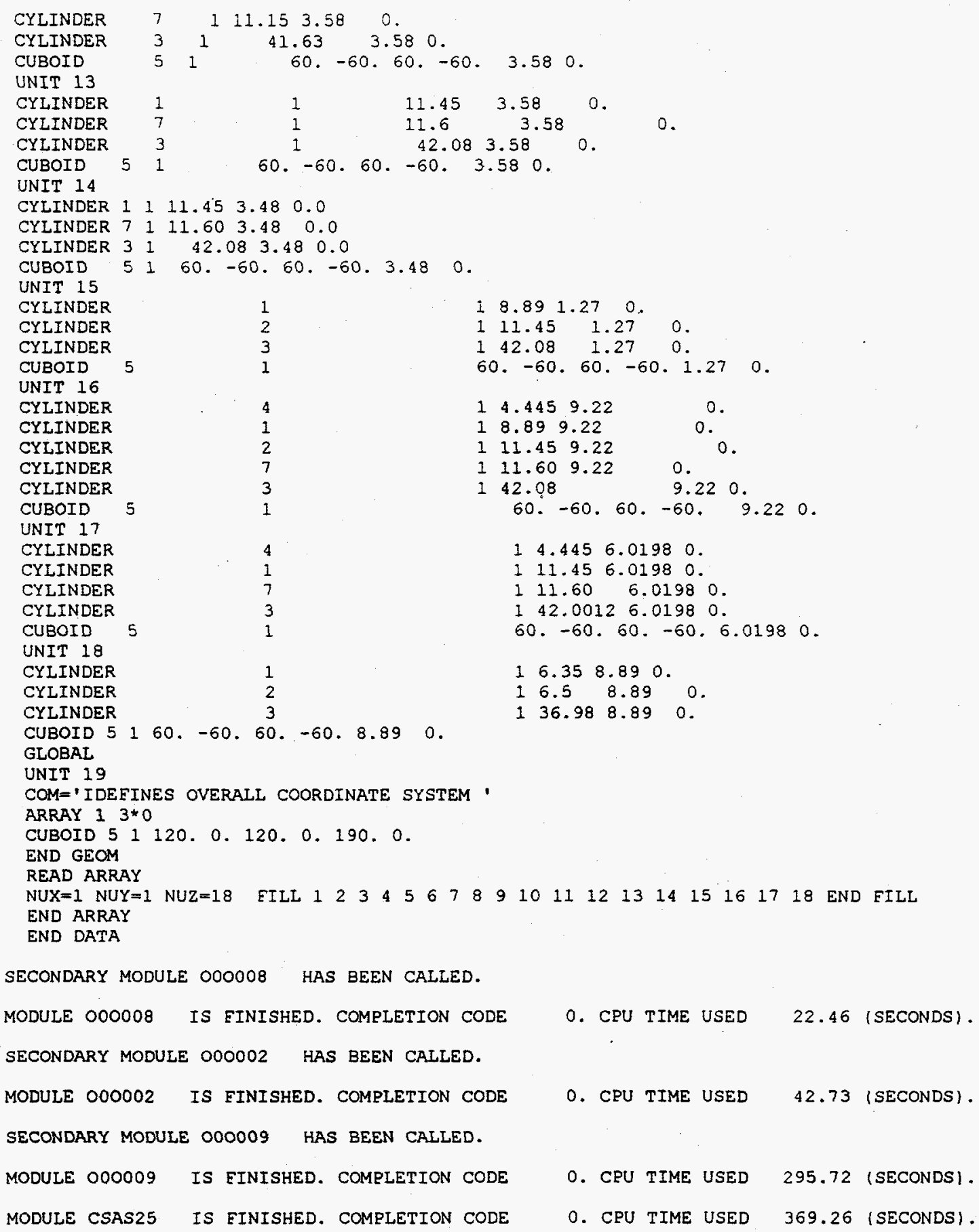

THE EOLLOWING DATA CARDS PRECEDE AN = CARD

EXECUTION TERMINATED DUE TO ERRORS 


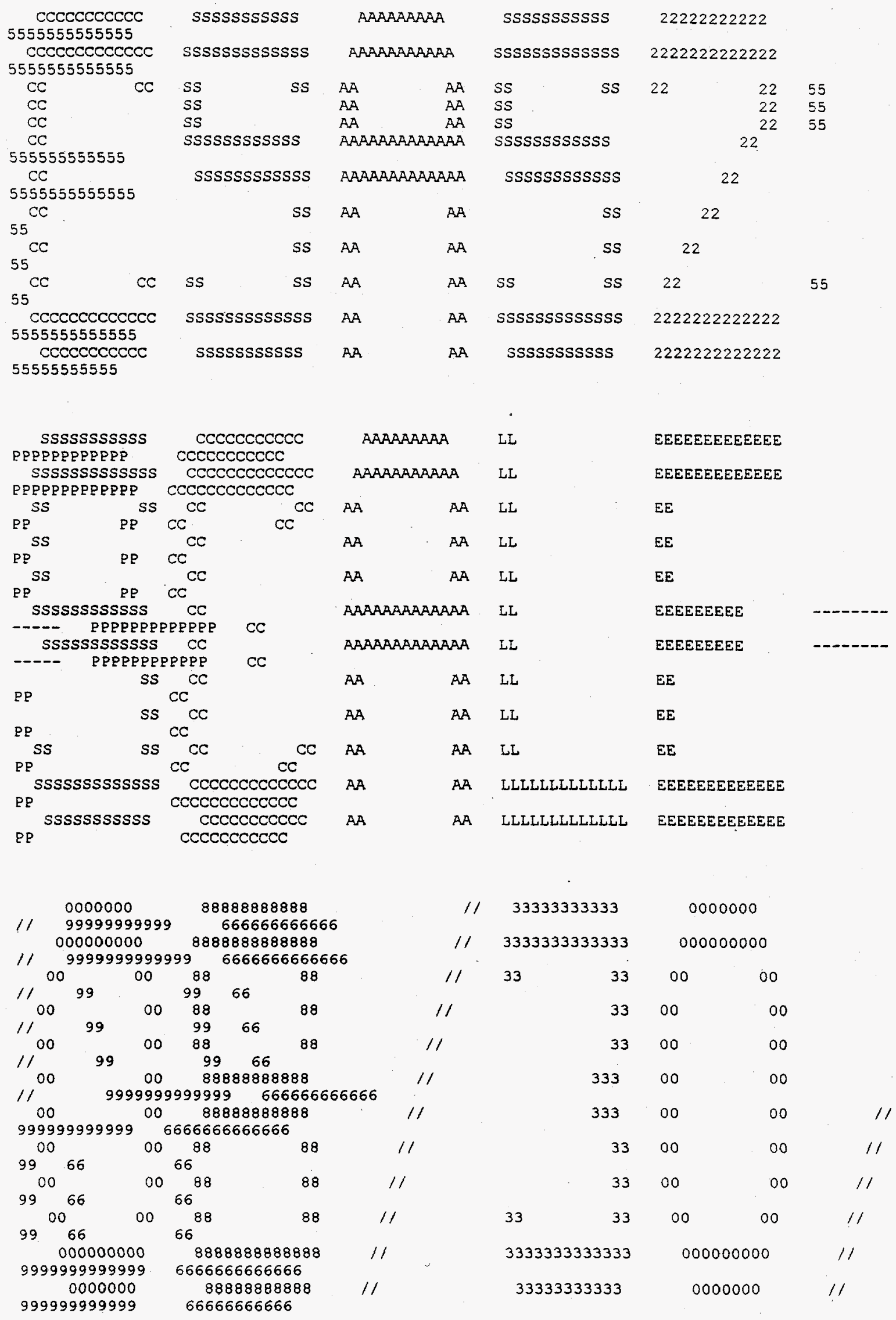




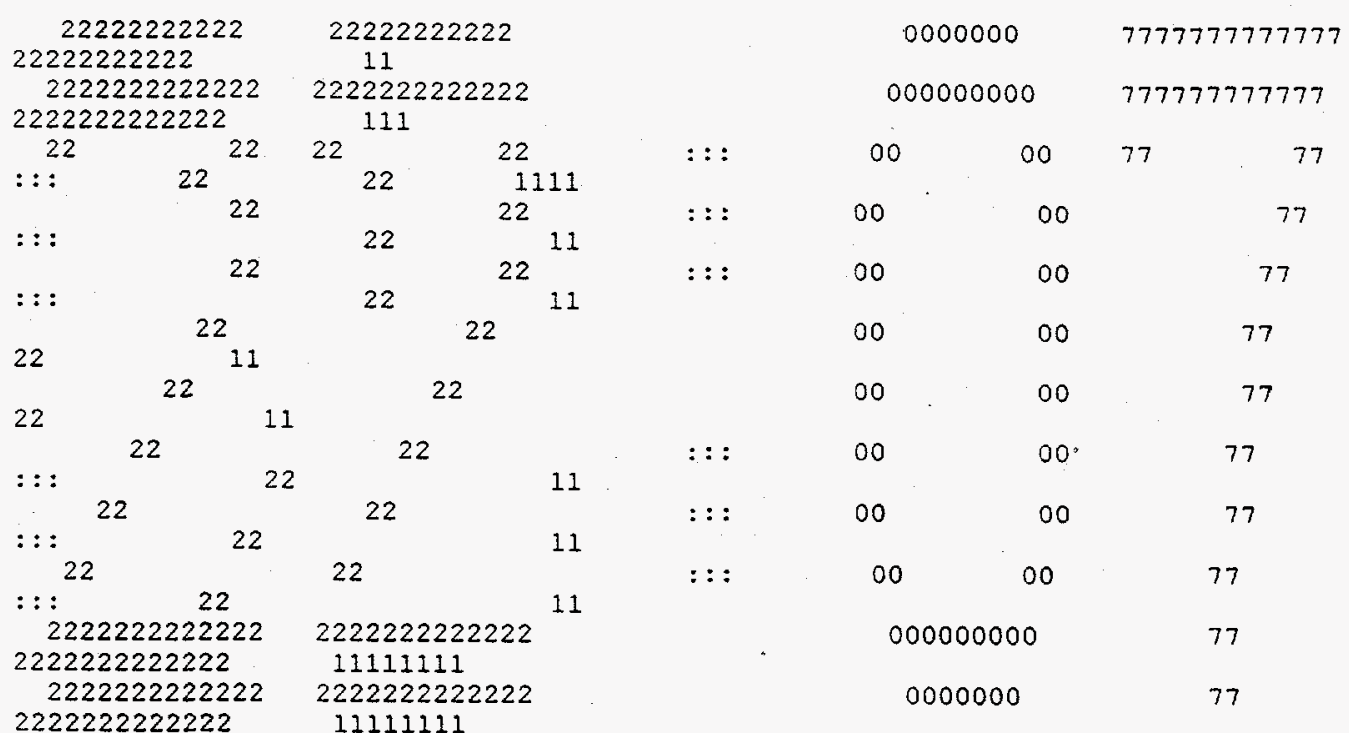




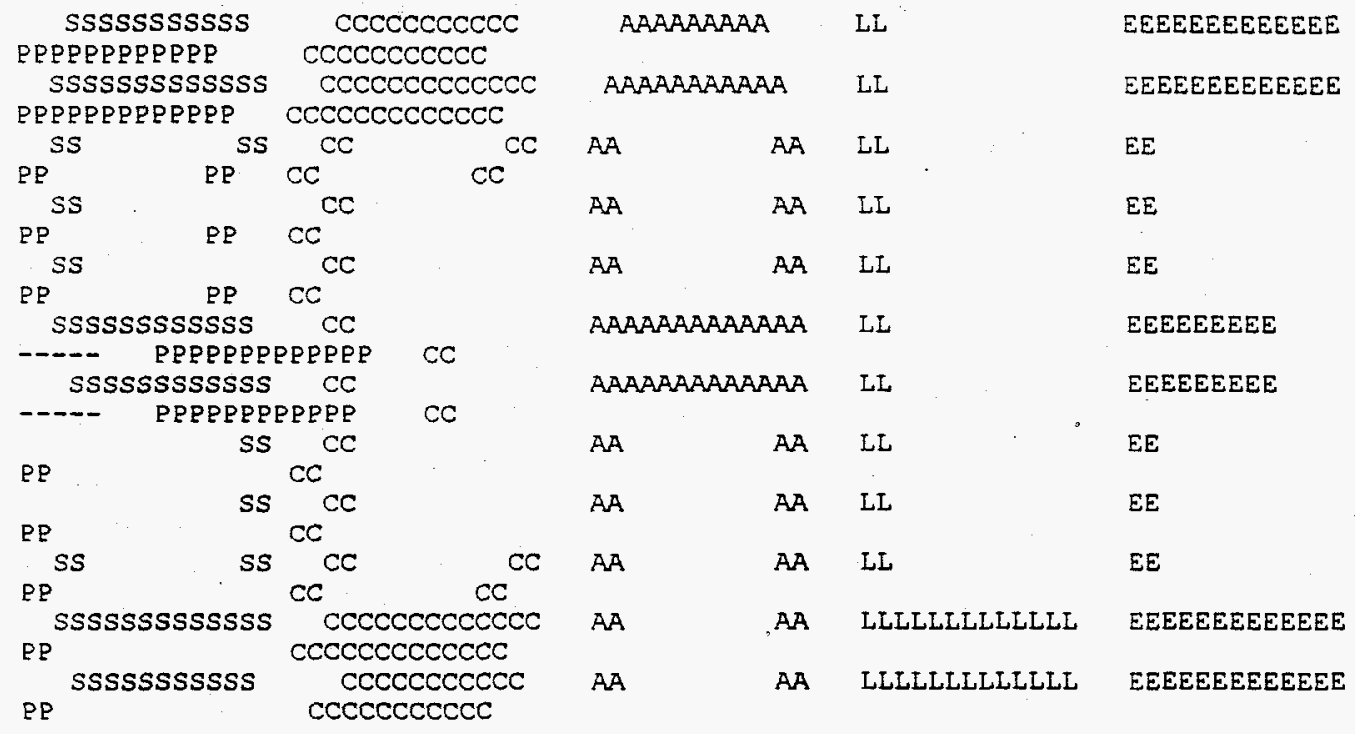

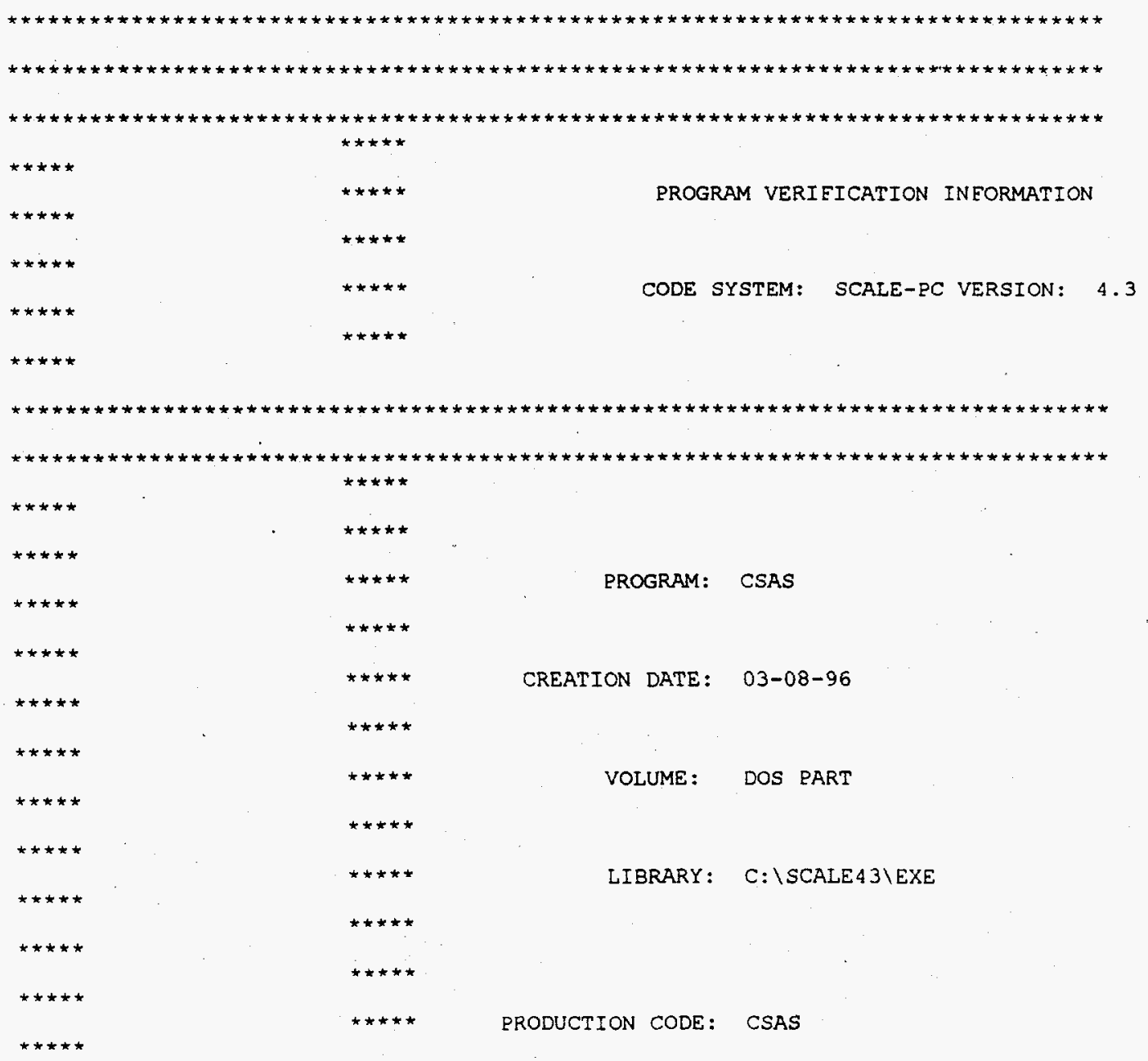




\section{F-8}

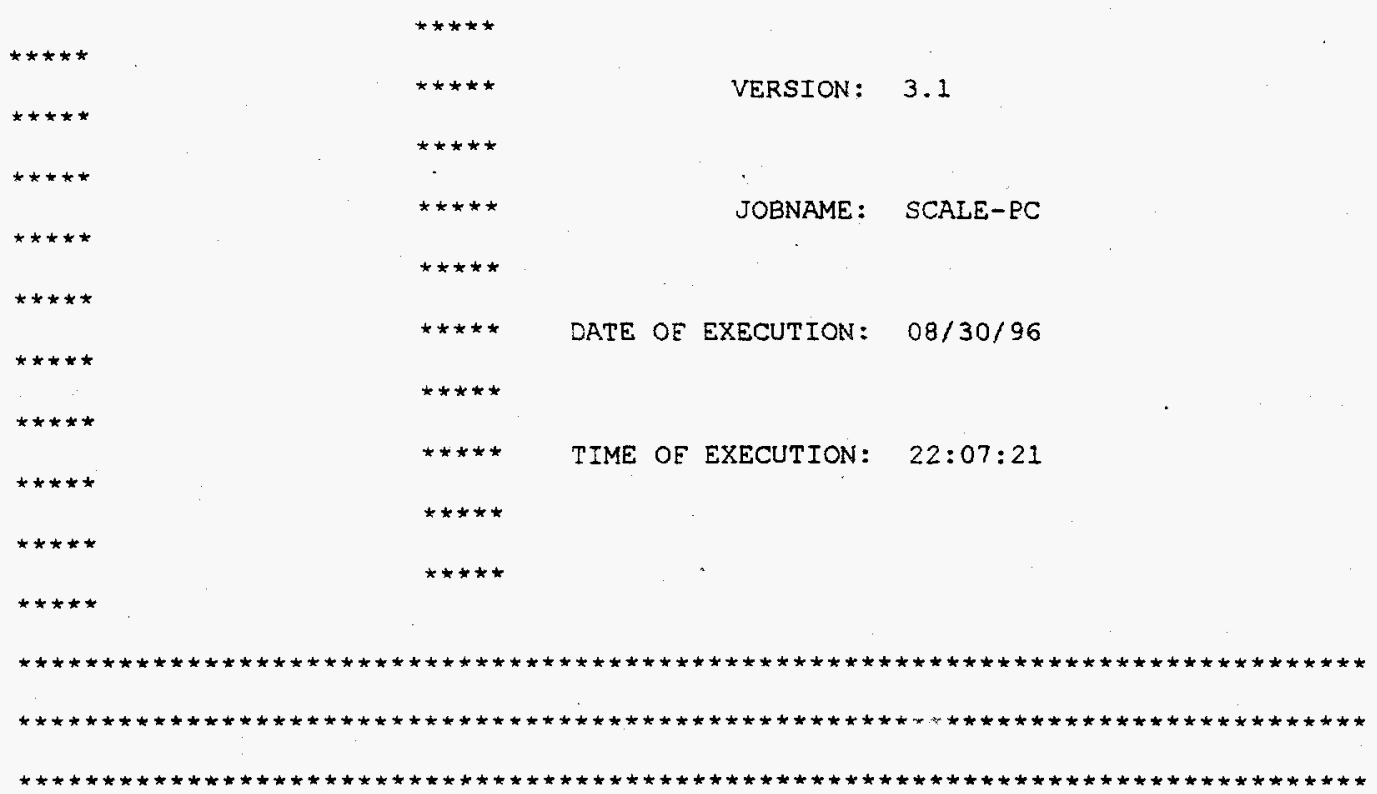




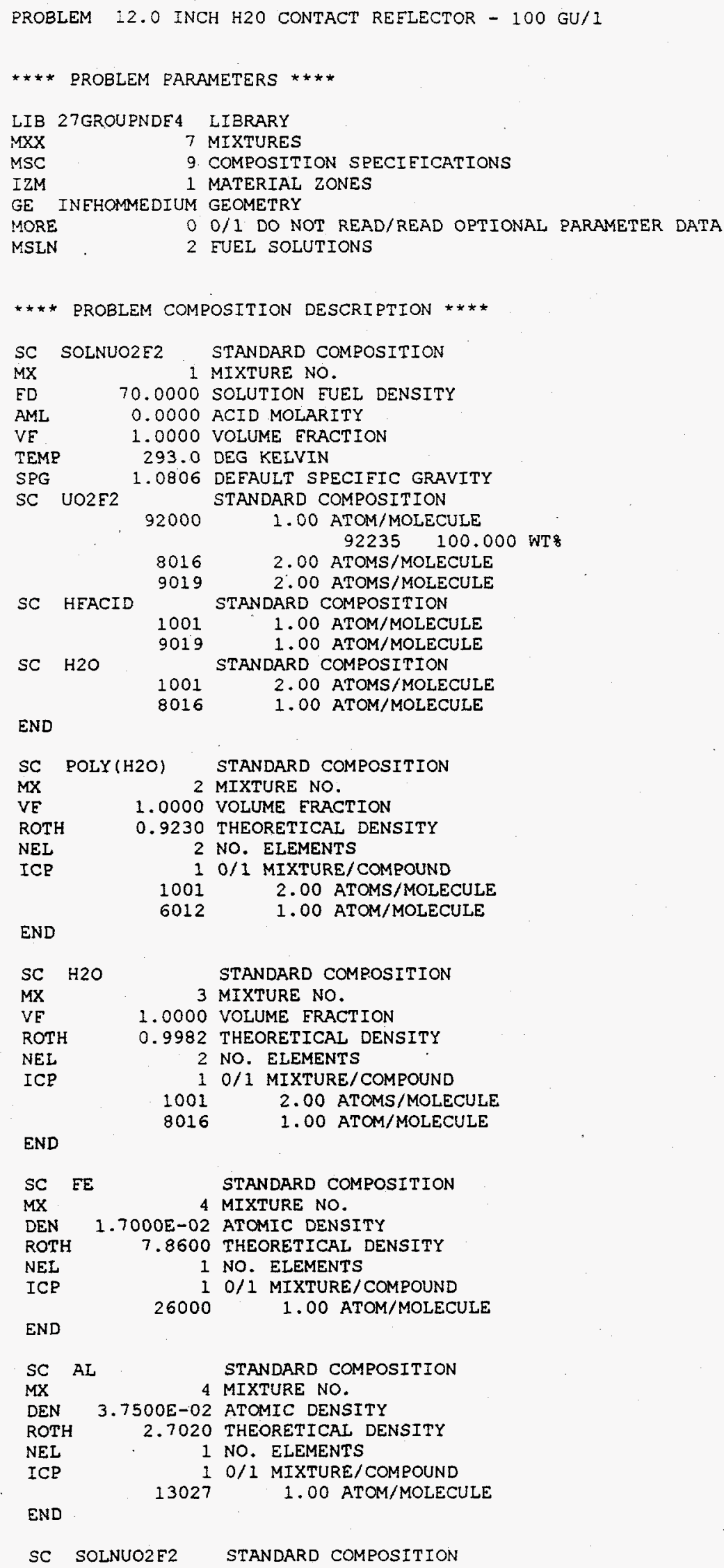




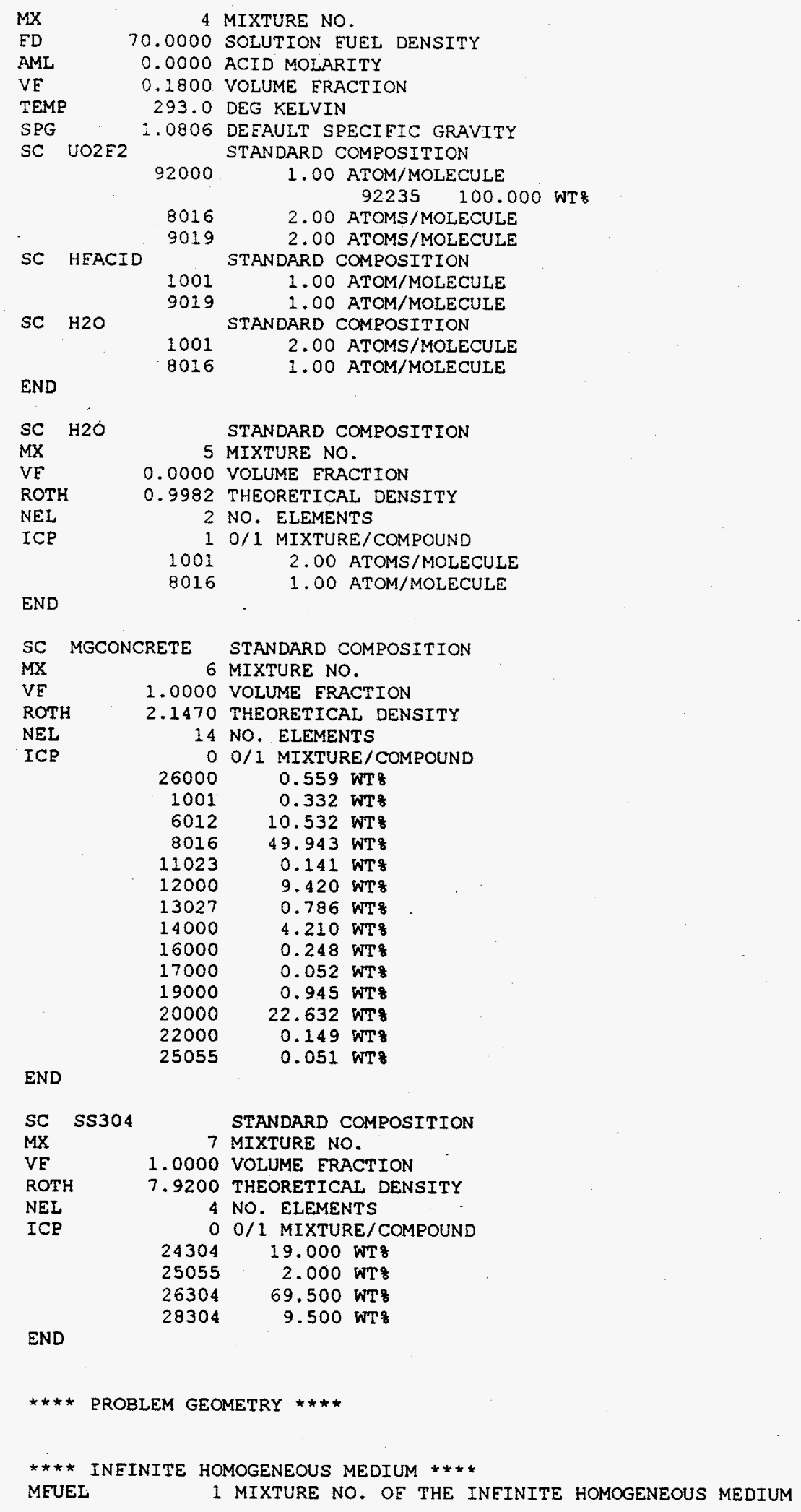




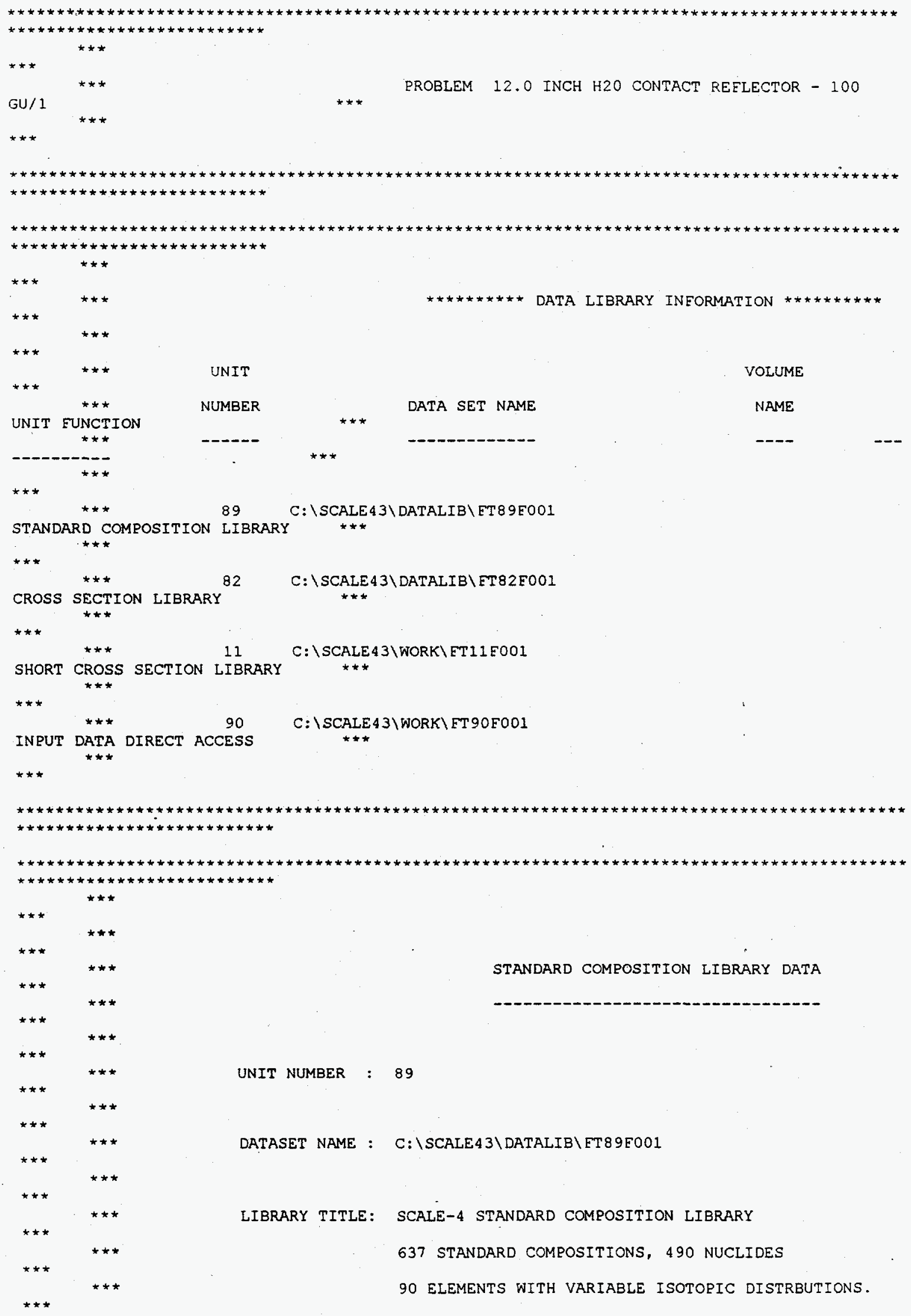




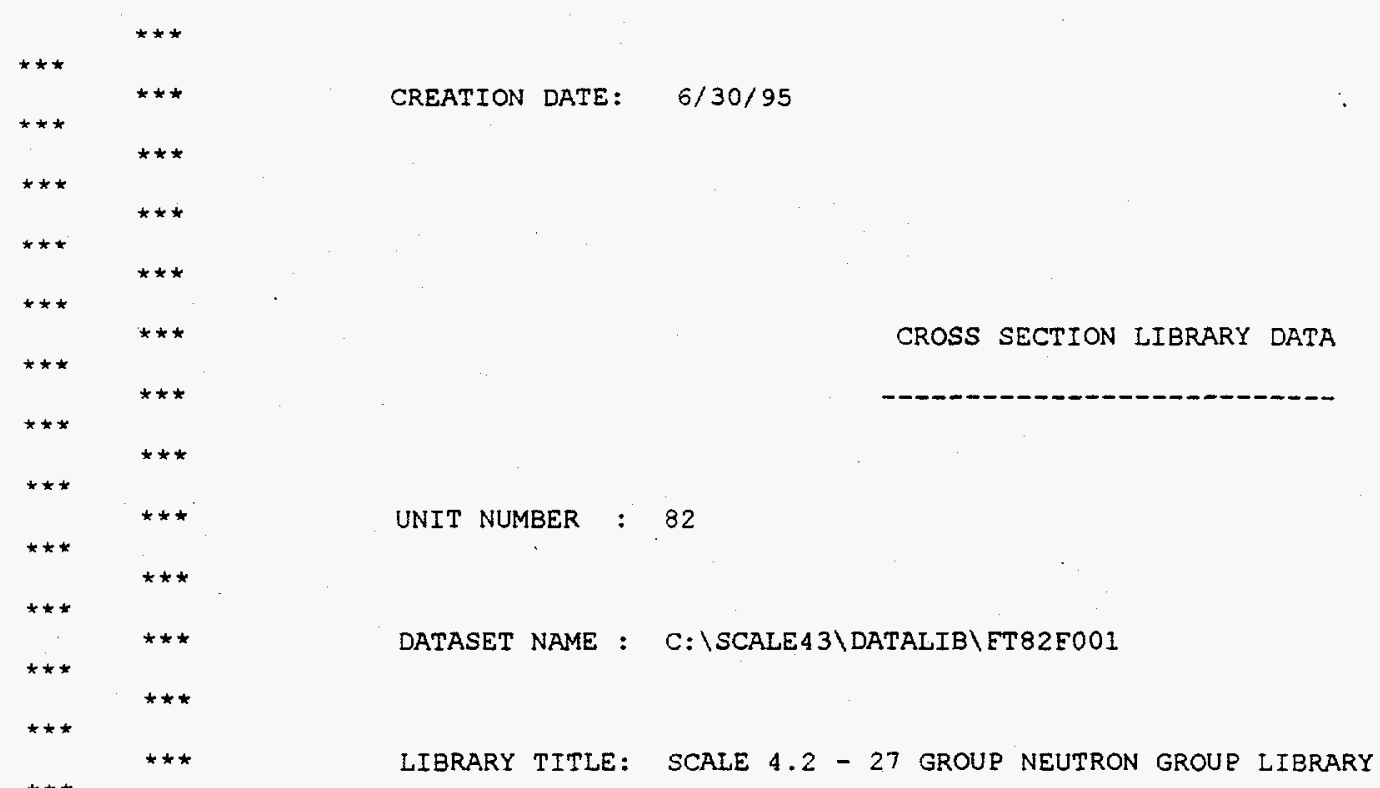

BASED ON ENDE-B VERSION 4 DATA

COMPILED EOR NRC $1 / 27 / 89$

LAST UPDATED

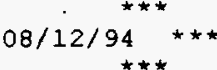

$\star \star \star *$

L.M. PETRIE - ORNL

$* * * \quad * * *$

$\star \star \star \star \star * * *$

$\star \star \star *$

$\star \star \star$

$\star \star \star$

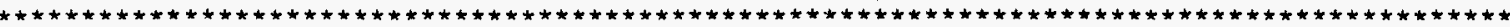

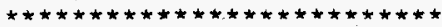

$\star \star * * * * * * * * * * * * * * * * * * * * * * * * *$

$\cdots \cdots \cdots$

DATA $\quad \cdots \cdots \cdots$

O IO'S WERE USED BEFORE READING KENO V DATA

0 IO'S WERE USED READING THE KENO $V$ PARAMETER

\section{data REAding compLeted}

DATA $\quad \ldots \ldots \ldots$

O IO'S WERE USED PREPARING THE KENO $V$ INPUT

$\ldots \ldots$

O IO'S WERE USED LOADING THE KENO V DATA

$\ldots \ldots \ldots$

O IO'S WERE USED LOADING THE DATA

DATA

$\ldots \ldots$

O IO'S WERE USED CHECKING THE KENO V GEOMETRY

***** RESTART DATA HAS BEEN WRITTEN ON UNIT $95 * * * *$

$\ldots \ldots \ldots$ o IO'S WERE USED WRITING THE KENO $V$ - CSAS DATA

$\ldots \ldots \ldots$

$\ldots \ldots \ldots$ O IO'S WERE USED PROCESSING CSAS INPUT DATA

CONTROL MODULE CSAS25 IS COMPLETE. 


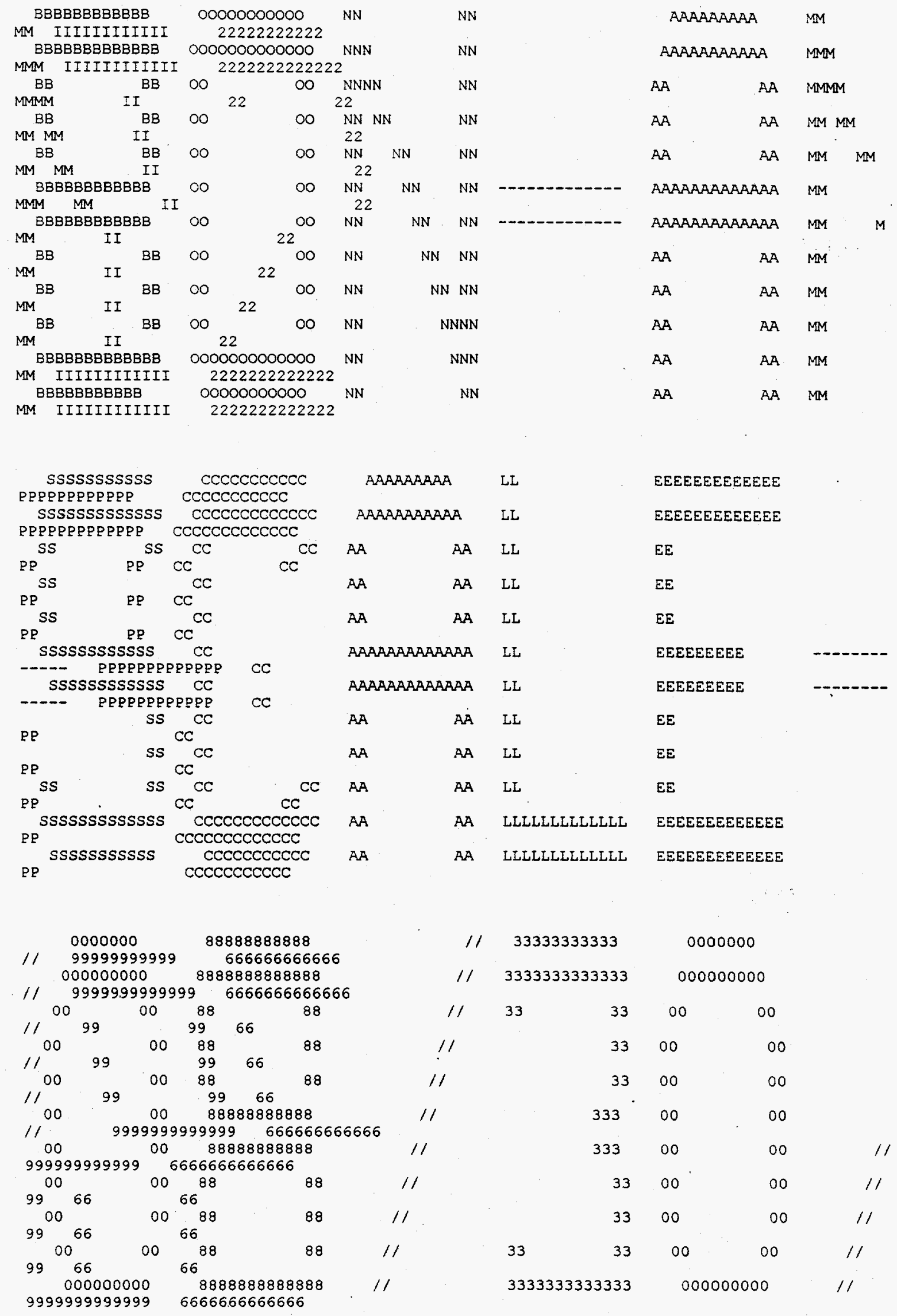


F-14

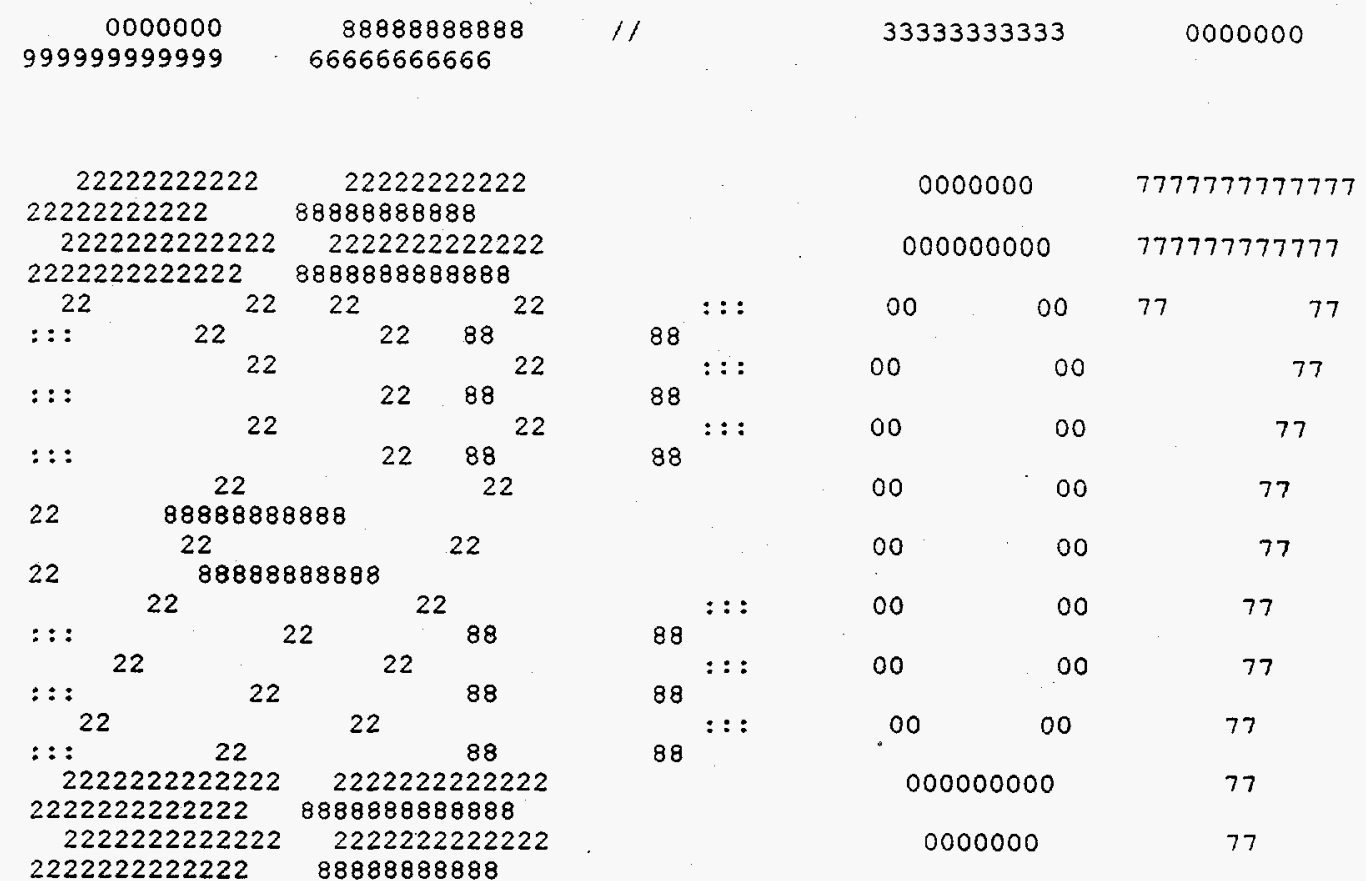




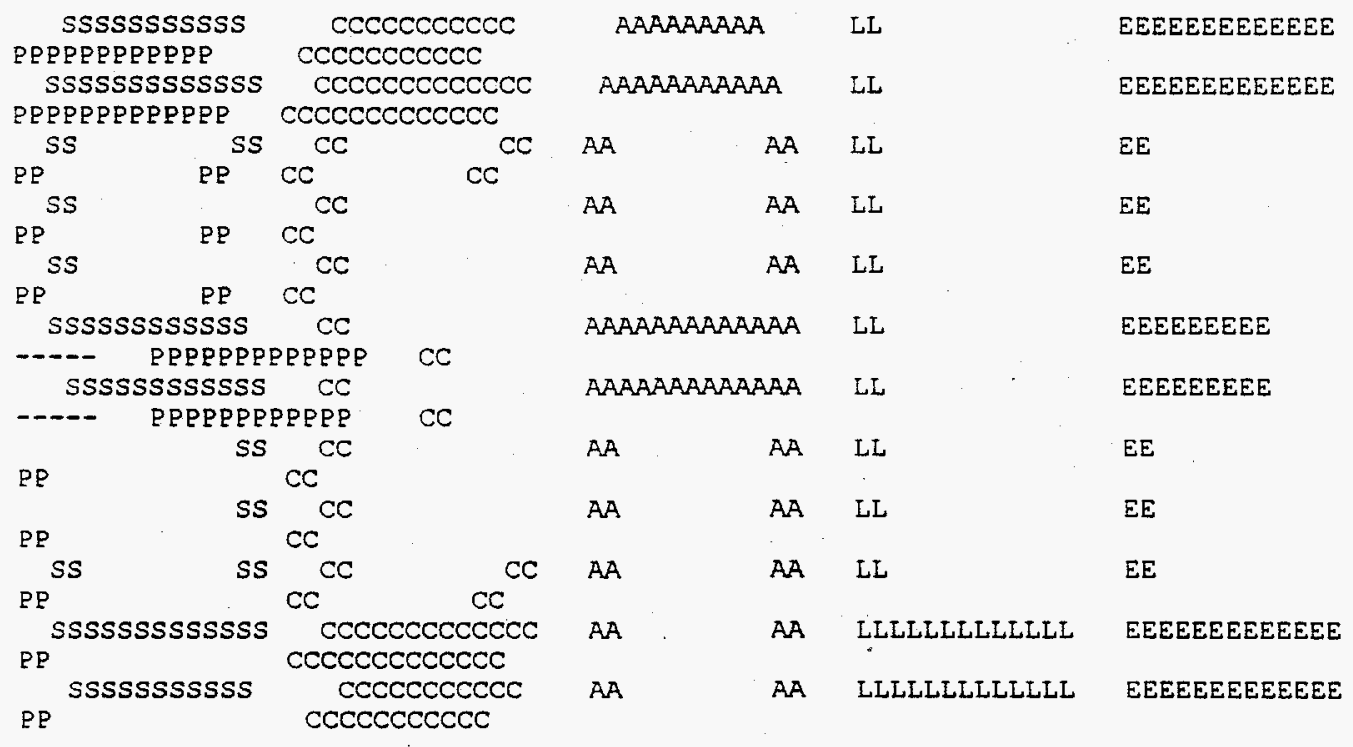

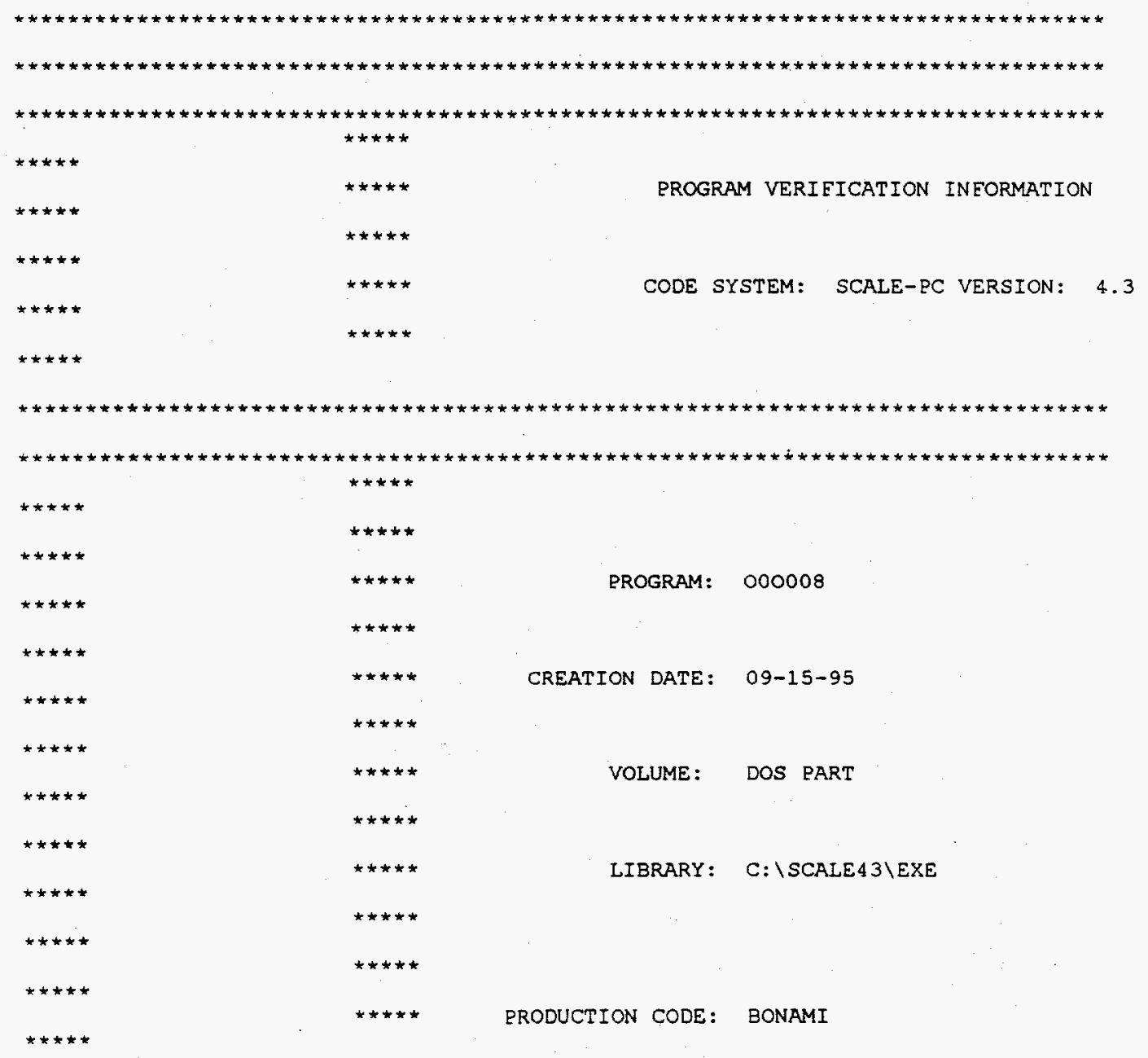




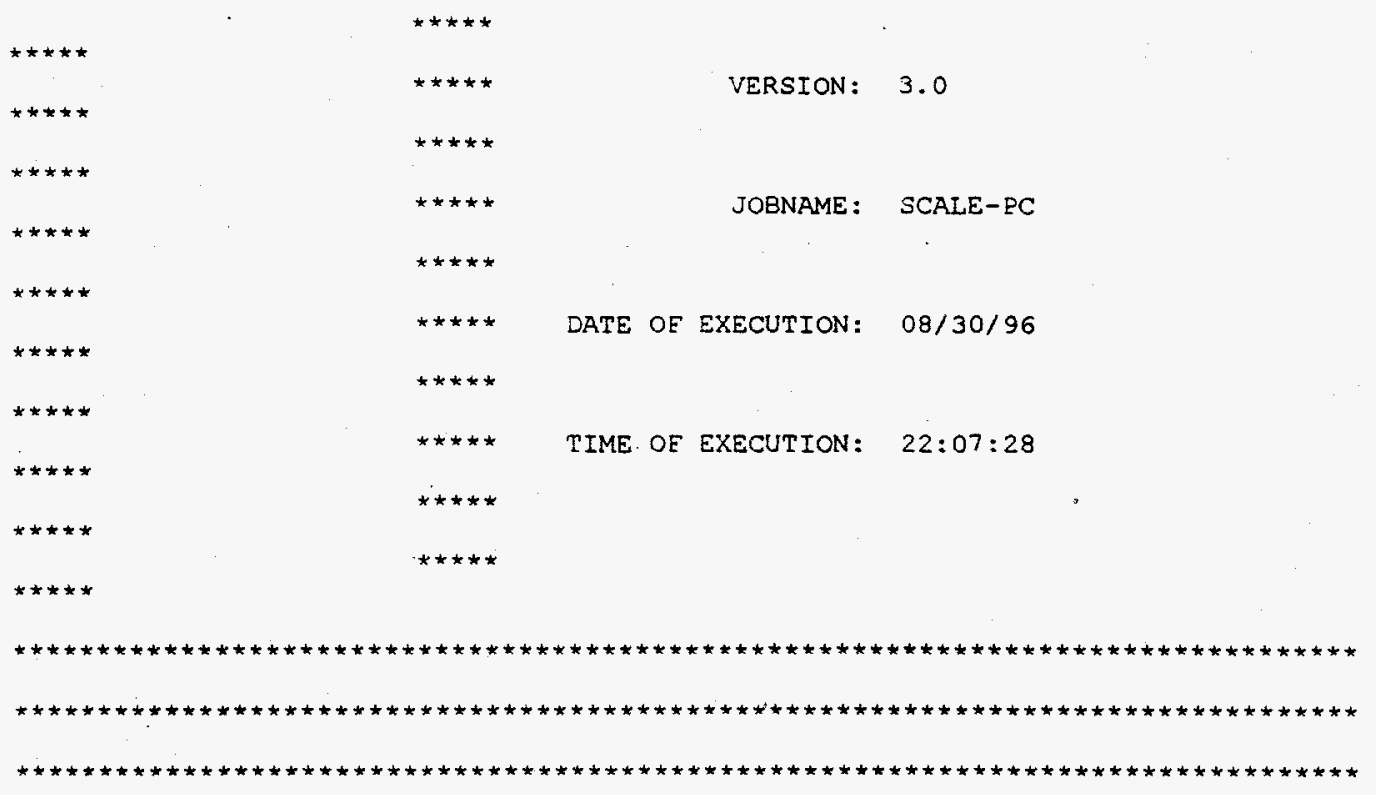


F-17
-10 ARRAY HAS
1 ENTRIES.
OQ ARRAY HAS
4 ENTRIES.
10 ARRAY HAS
6 ENTRIES.
20 ARRAY HAS
2 ENTRIES. 
LOGICAL ASSIGNMENTS

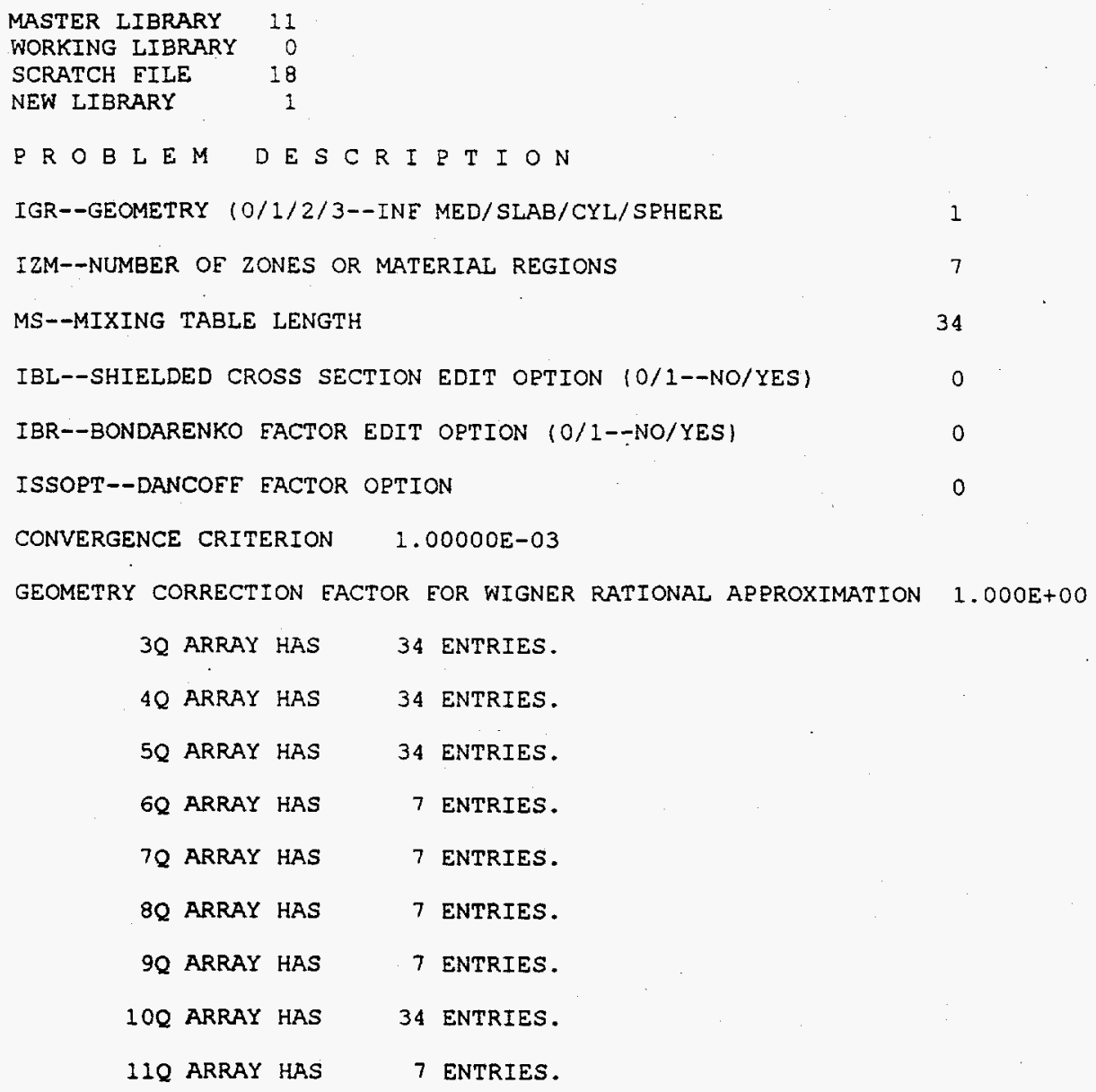




$\begin{array}{lllll}31 & 7 & 25055 & 1.73633 E-03 & 7025055 \\ 32 & 7 & 24304 & 1.74286 E-02 & 7024304 \\ 33 & 7 & 26304 & 5.93579 E-02 & 7026304 \\ 34 & 7 & 28304 & 7.72070 E-03 & 7028304\end{array}$

GEOMETRY AND MATERIAL DESCRIPTION

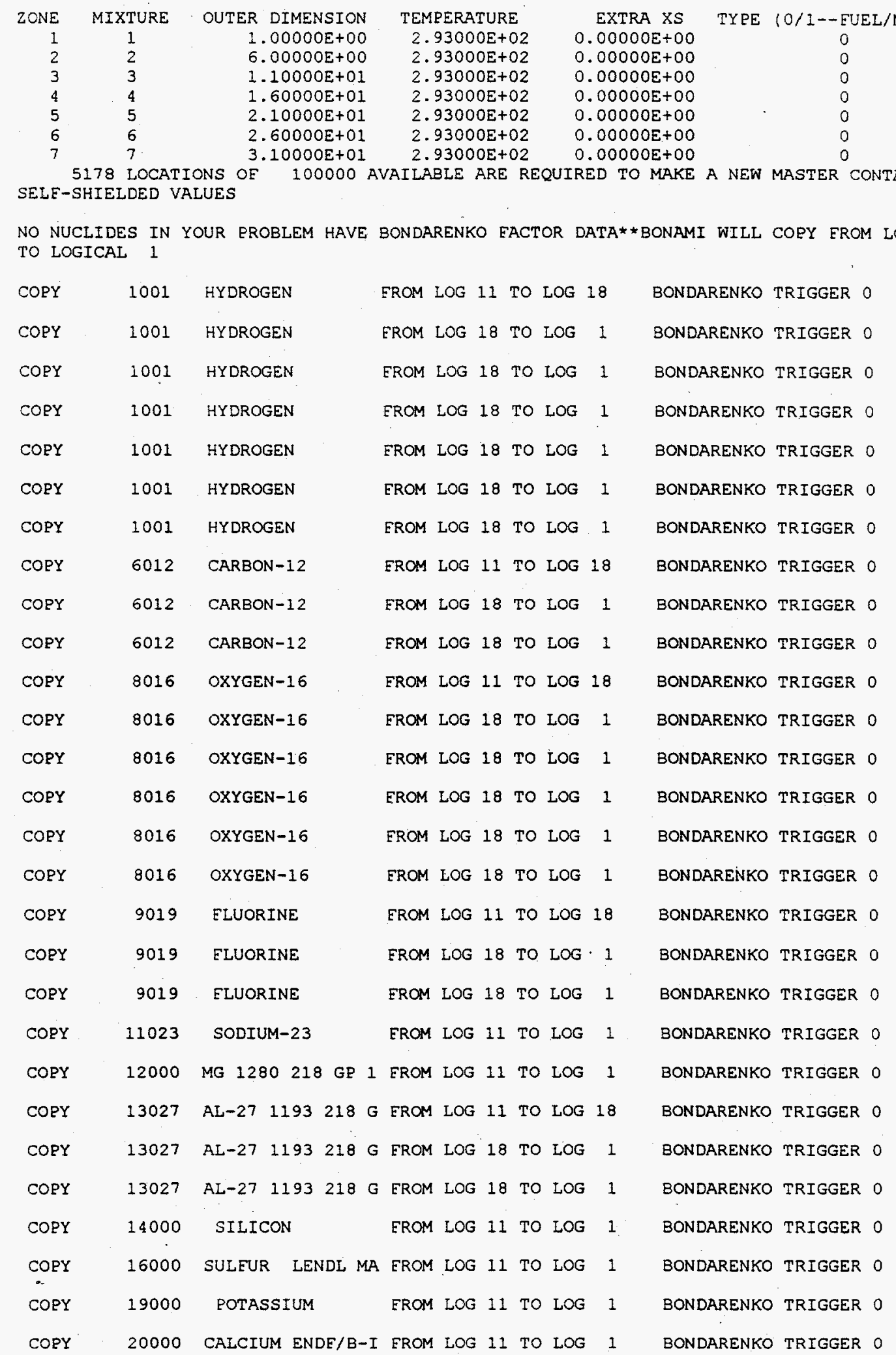




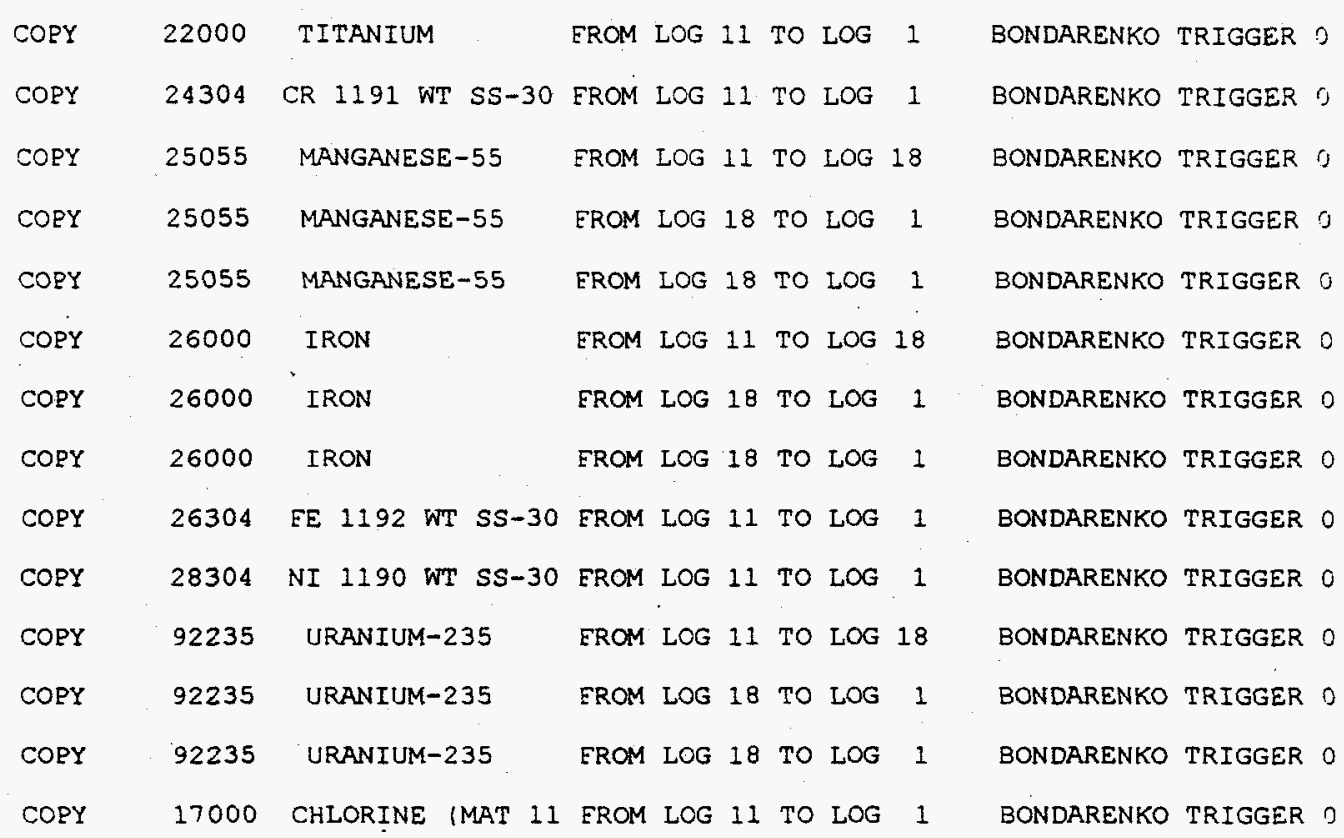




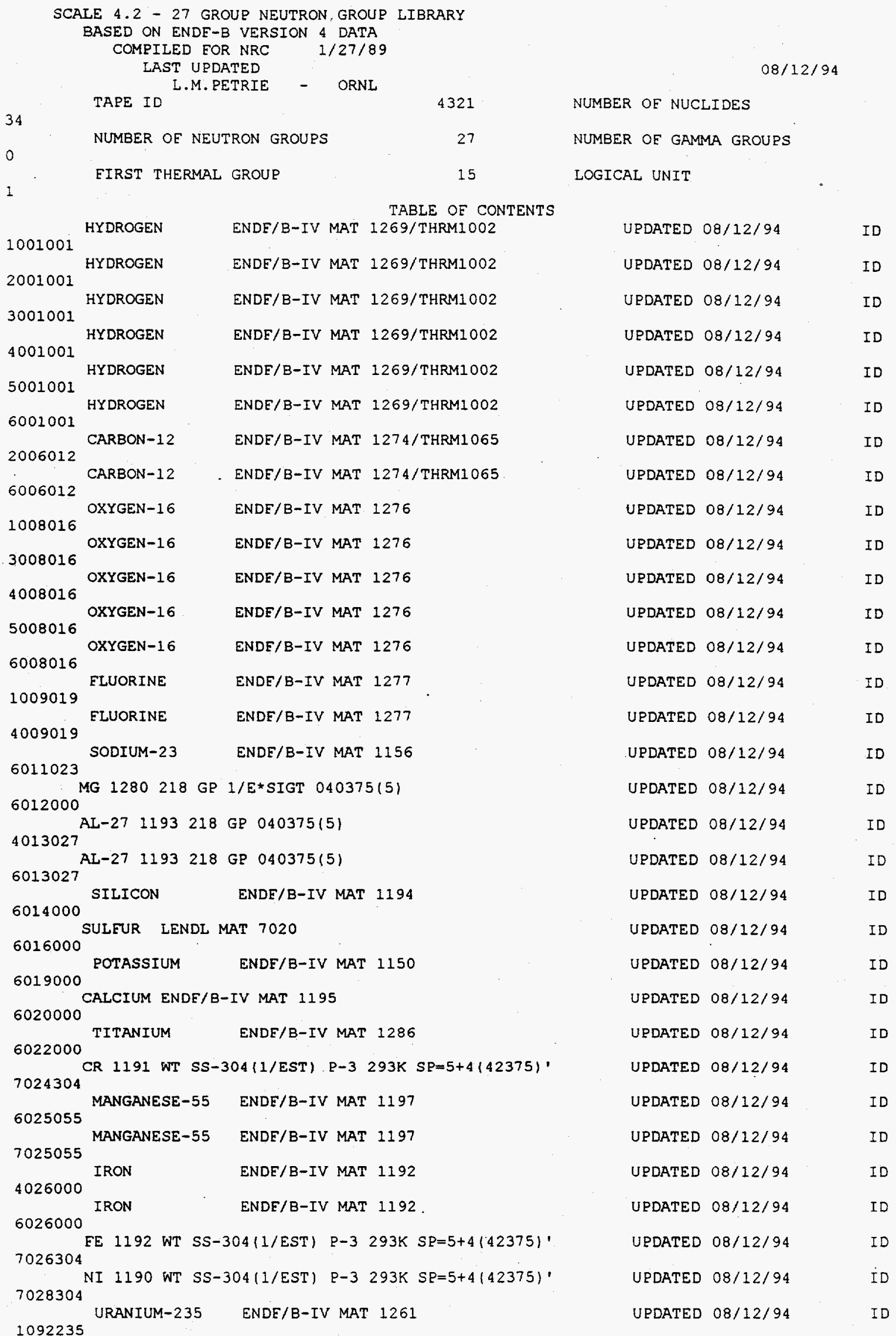


URANIUM-235 ENDE/B-IV MAT 1261

UPDATED 08/12/94

4092235

CHLORINE (MAT 1149 EROM VERSION IV) USING 1/SIGT WEIGHTIUPDATED 08/12/94 6017000

TAPE COPY USED

I/O'S, AND TOOK

12.90 SECONDS 


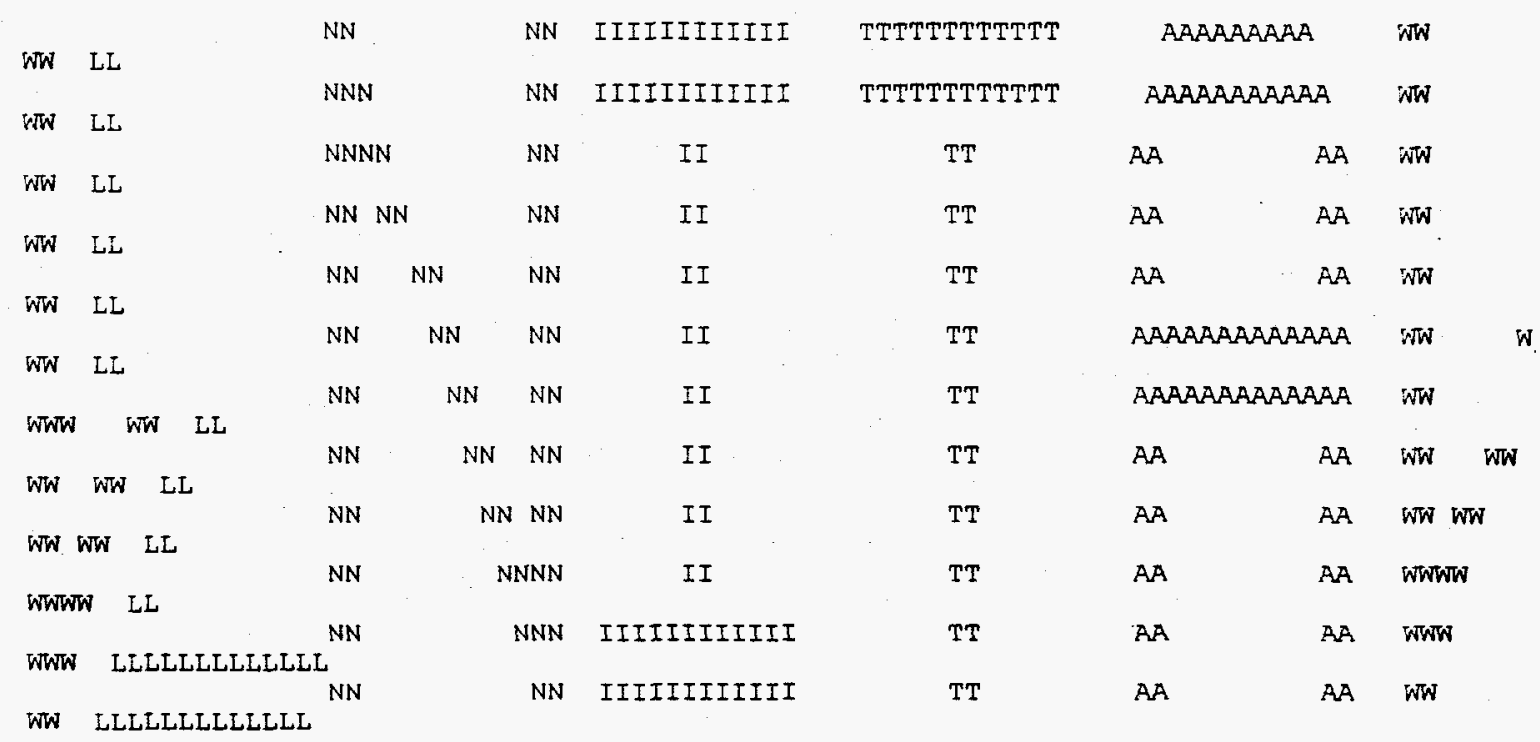

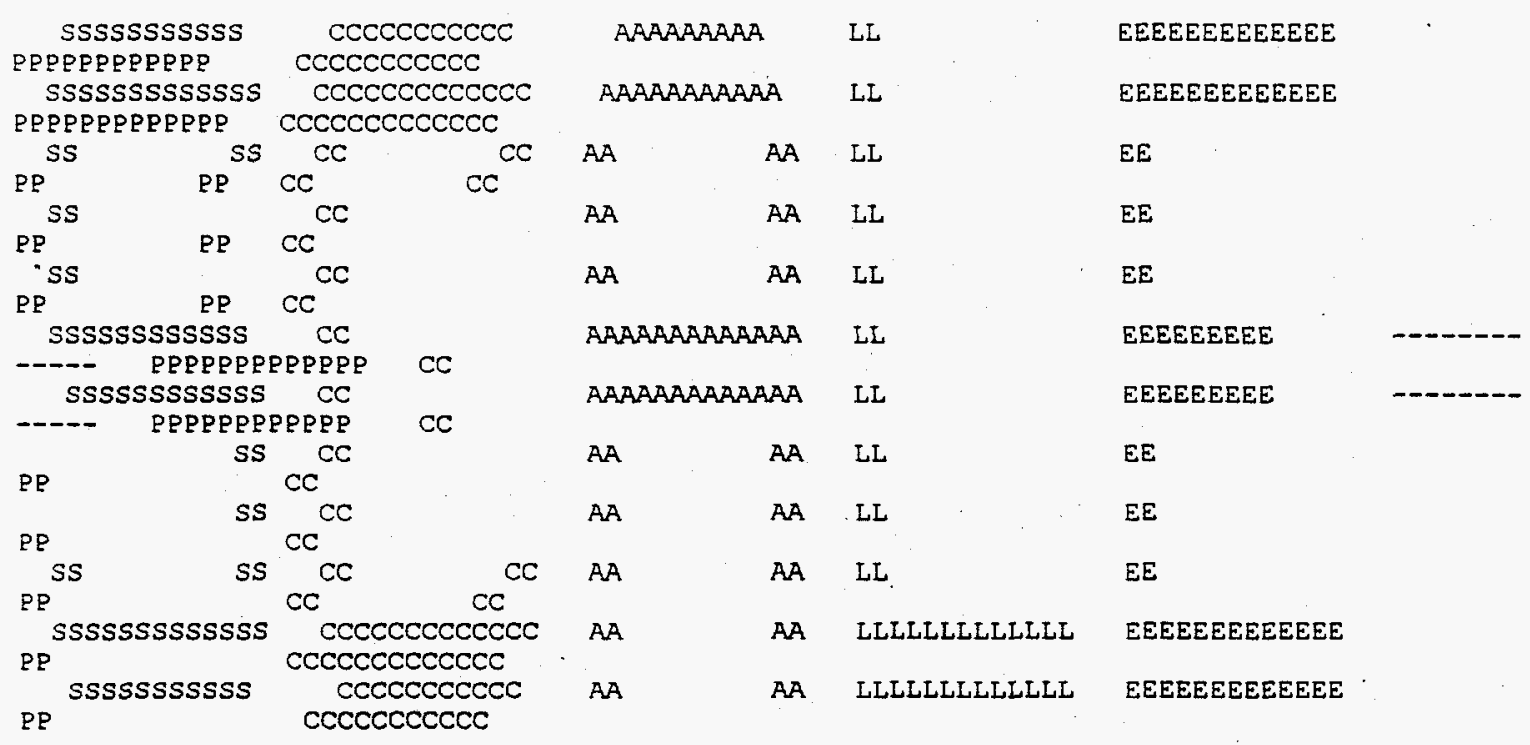

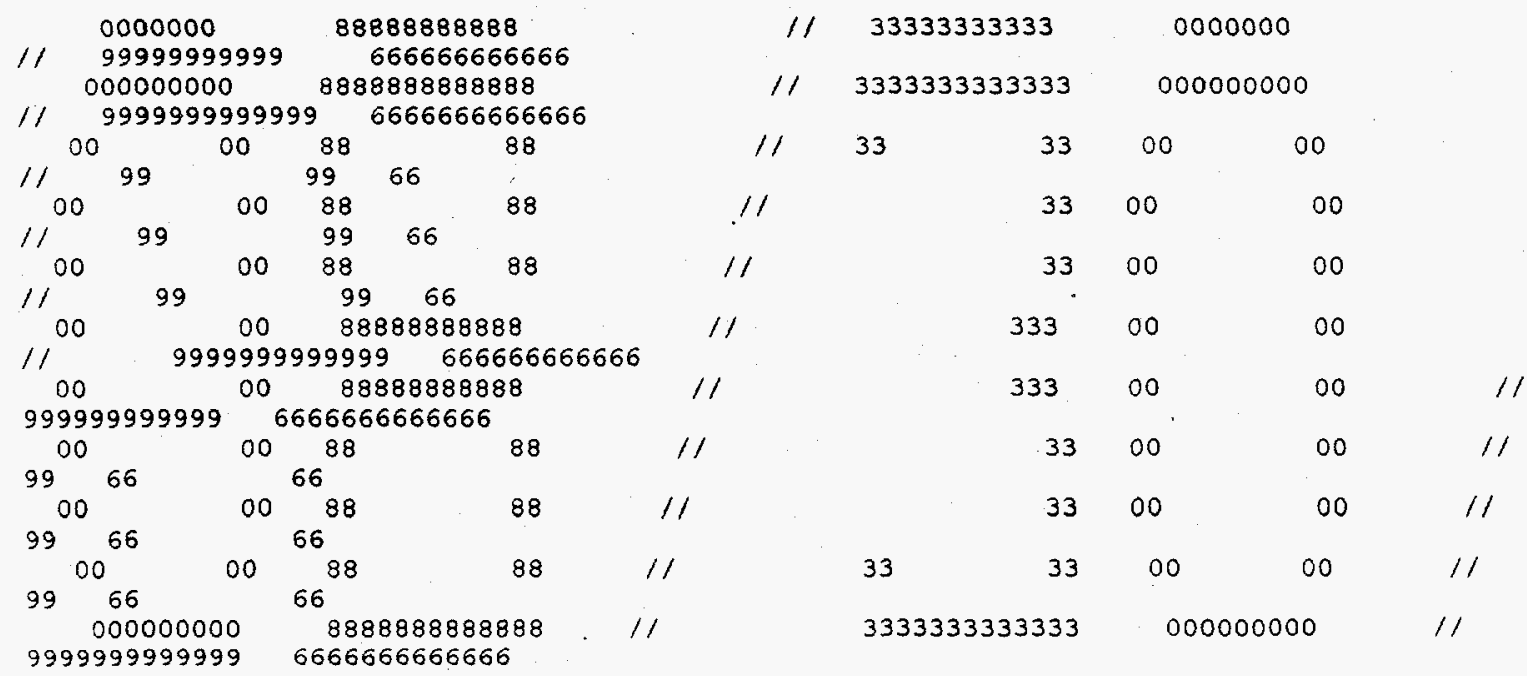


F-24

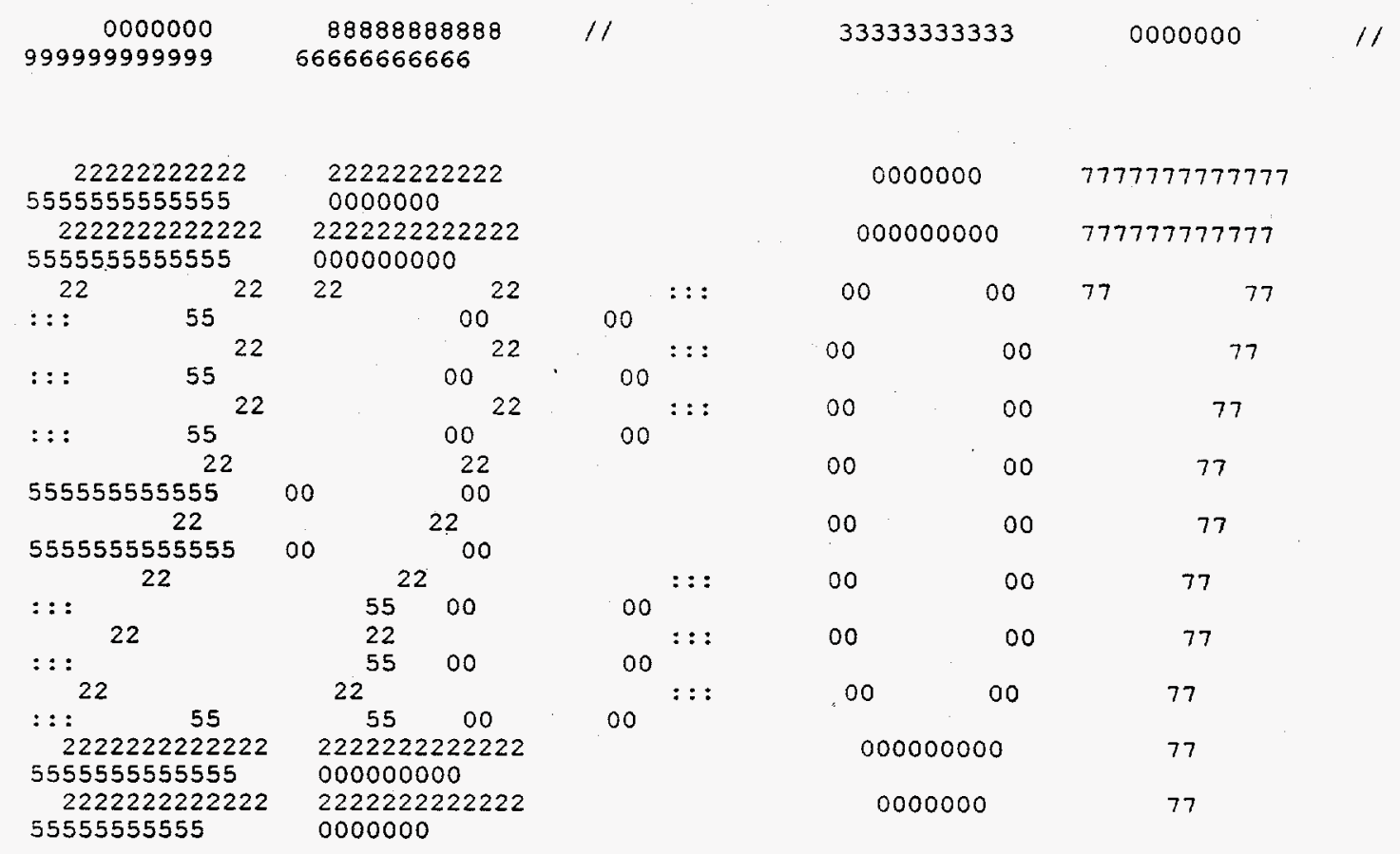




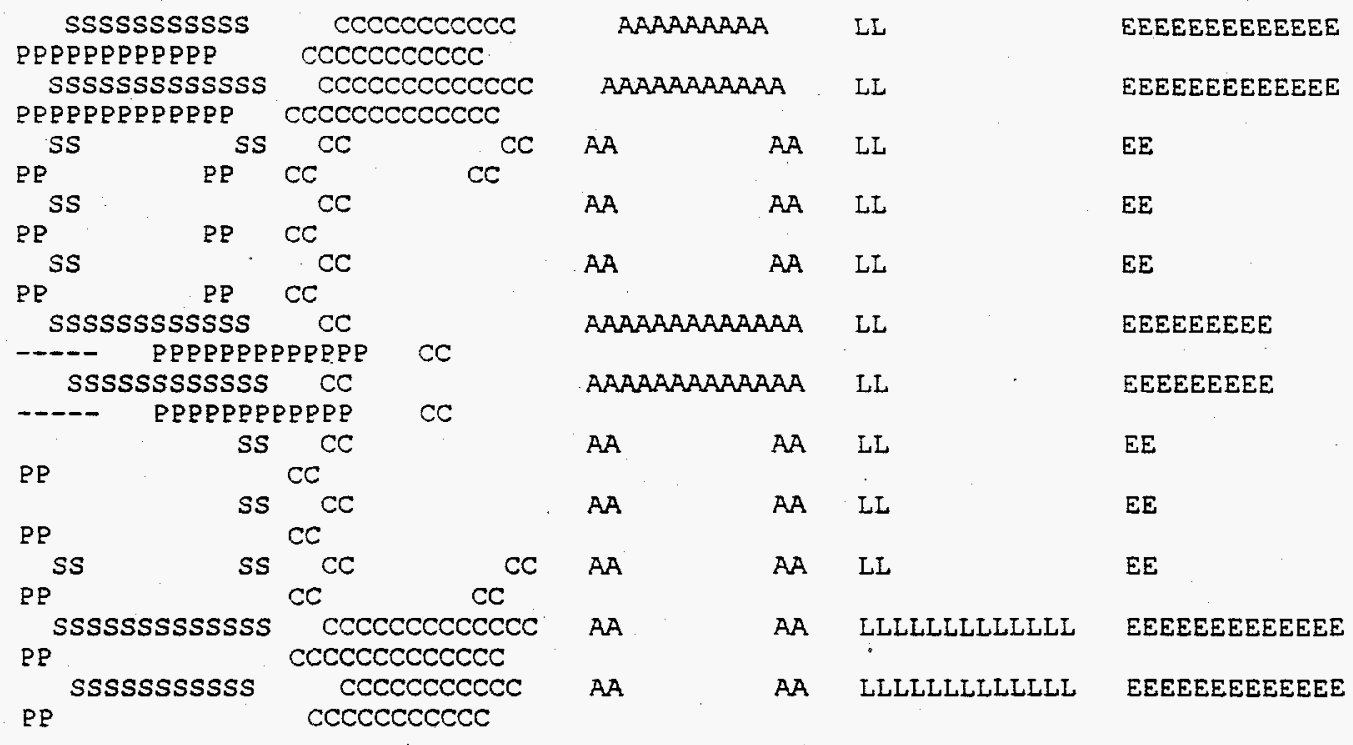

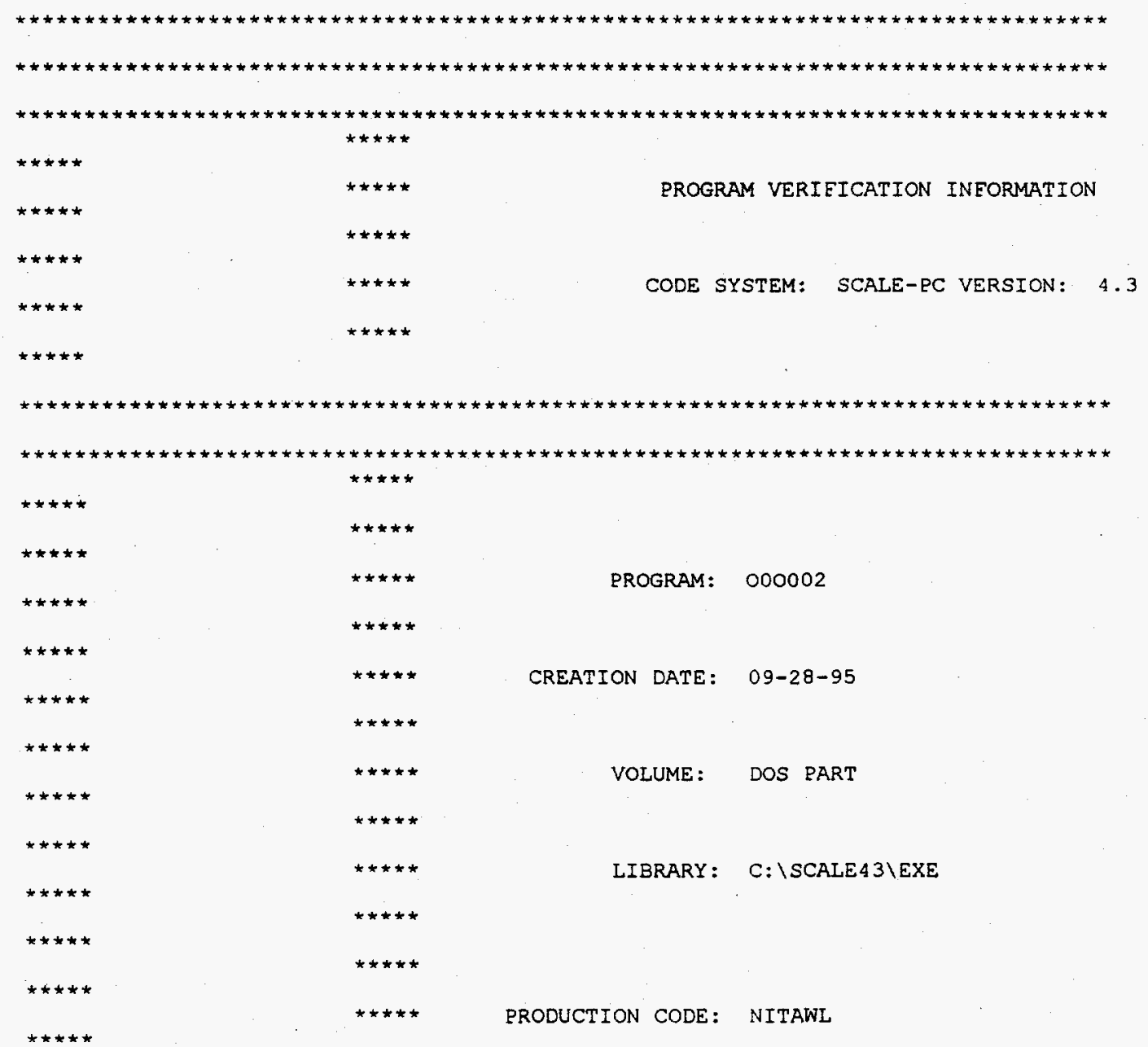




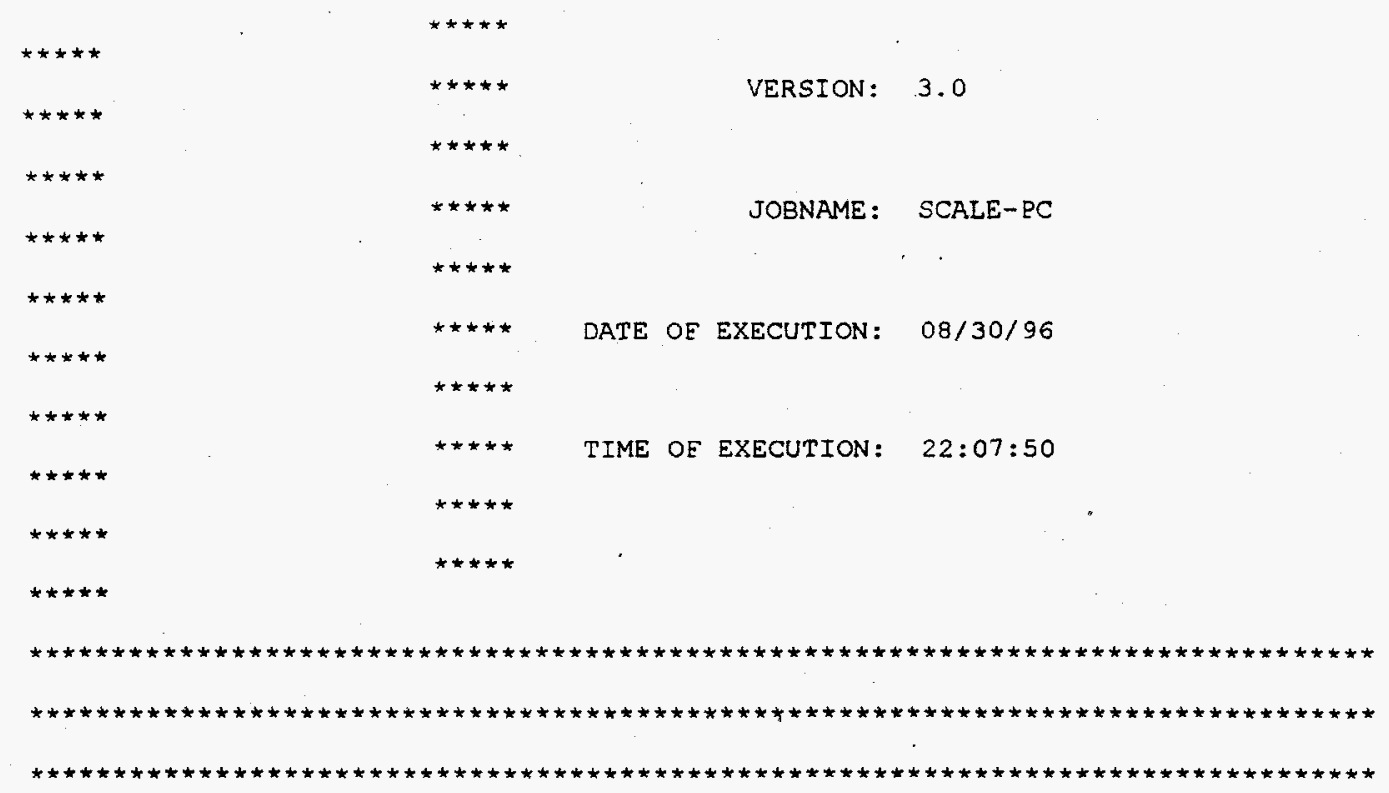




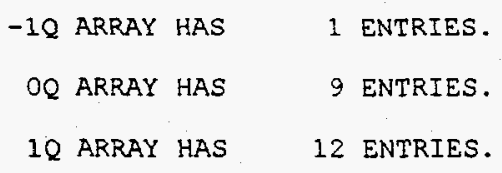

SELECT 34 NUCLIDES EROM THE MASTER LIBRARY ON LOGICAL I

O NUCLIDES EROM THE WORKING LIBRARY ON LOGICAL 2

O NUCLIDES FROM THE WORKING LIBRARY ON LOGICAL 3 TO CREATE THE NEW WORKING LIBRARY ON LOGICAL 4

7 RESONANCE CALCULATIONS HAVE BEEN REQUESTED

-1 OUTPUT ORTION EOR AMPX EORMATTED CROSS SECTION DATA 2001 MAXIMUM NUMBER OE RESONANCE MESH INTERVALS

2 ORDER OE RESONANCE LEVEL PROCESSING

THE STORAGE ALIOCATED FOR THIS CASE IS 100000 WORDS
20 ARRAY HAS
34 ENTRIES.
30 ARRAY HAS
105 ENTRIES.
4Q ARRAY HAS
34 ENTRIES.
GENERAL INFORMATION CONCERNING CROSS SECTION LIBRARY
TAPE IDENTIEICATION NUMBER 4321
NUMBER OF NUCLIDES ON TAPE
NUMBER OF NEUTRON ENERGY GROUPS
EIRST THERMAL NEUTRON ENERGY GROUP
NUMBER OF GAMMA ENERGY GROUPS

4321
34
27
15
0

DIRECT ACCESS UNIT NUMBER 9 REQUIRES 118 BLOCKS OF LENGTH 1680 WORDS XSDRN TAPE 4321

SCALE 4.2 - 27 GROUP NEUTRON GROUP LIBRARY BASED ON ENDF-B VERSION 4 DATA COMPILED FOR NRC $1 / 27 / 89$

$08 / 12 / 94$ LAST UPDATED

$$
\text { L.M.PETRIE - ORNL }
$$

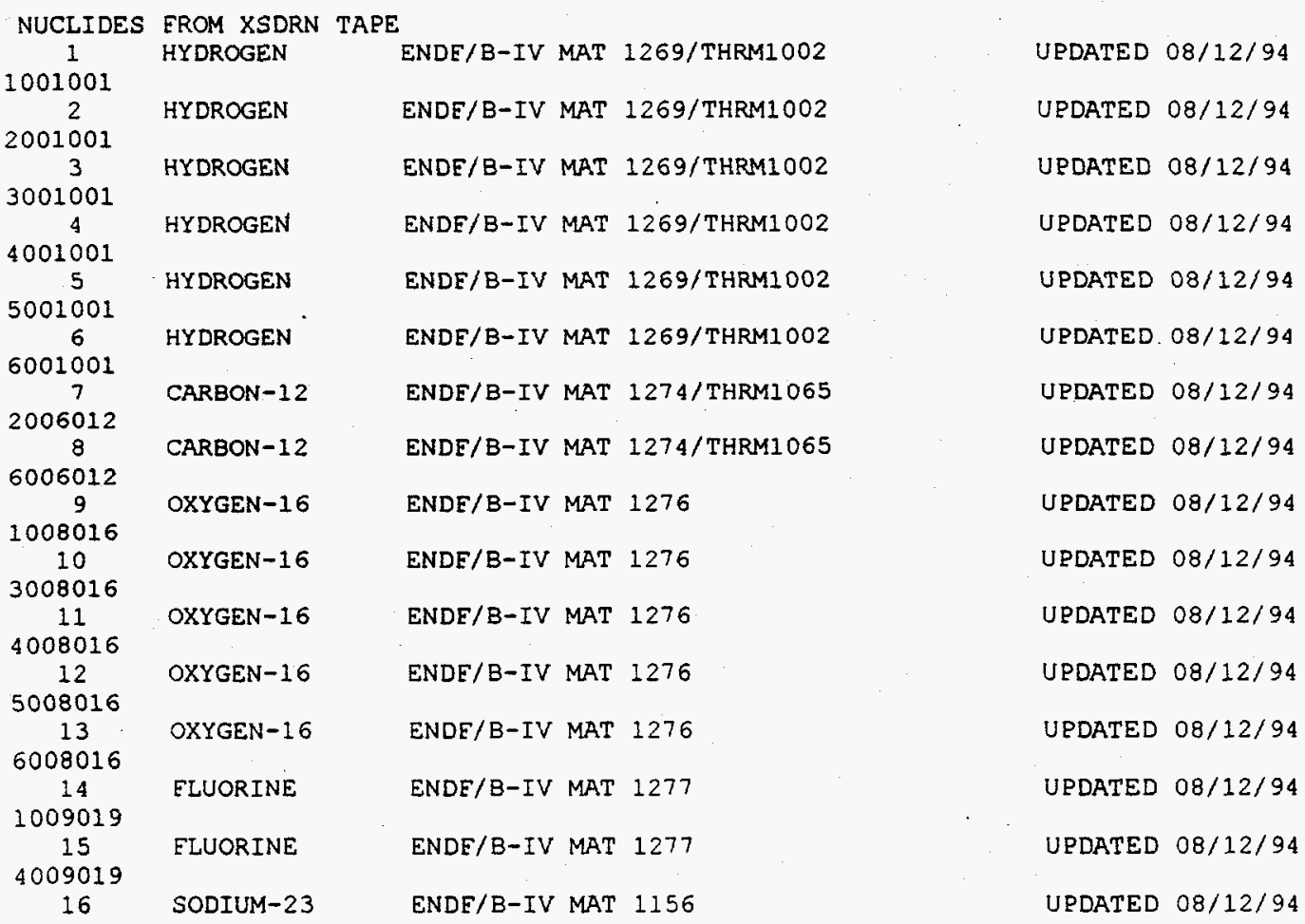




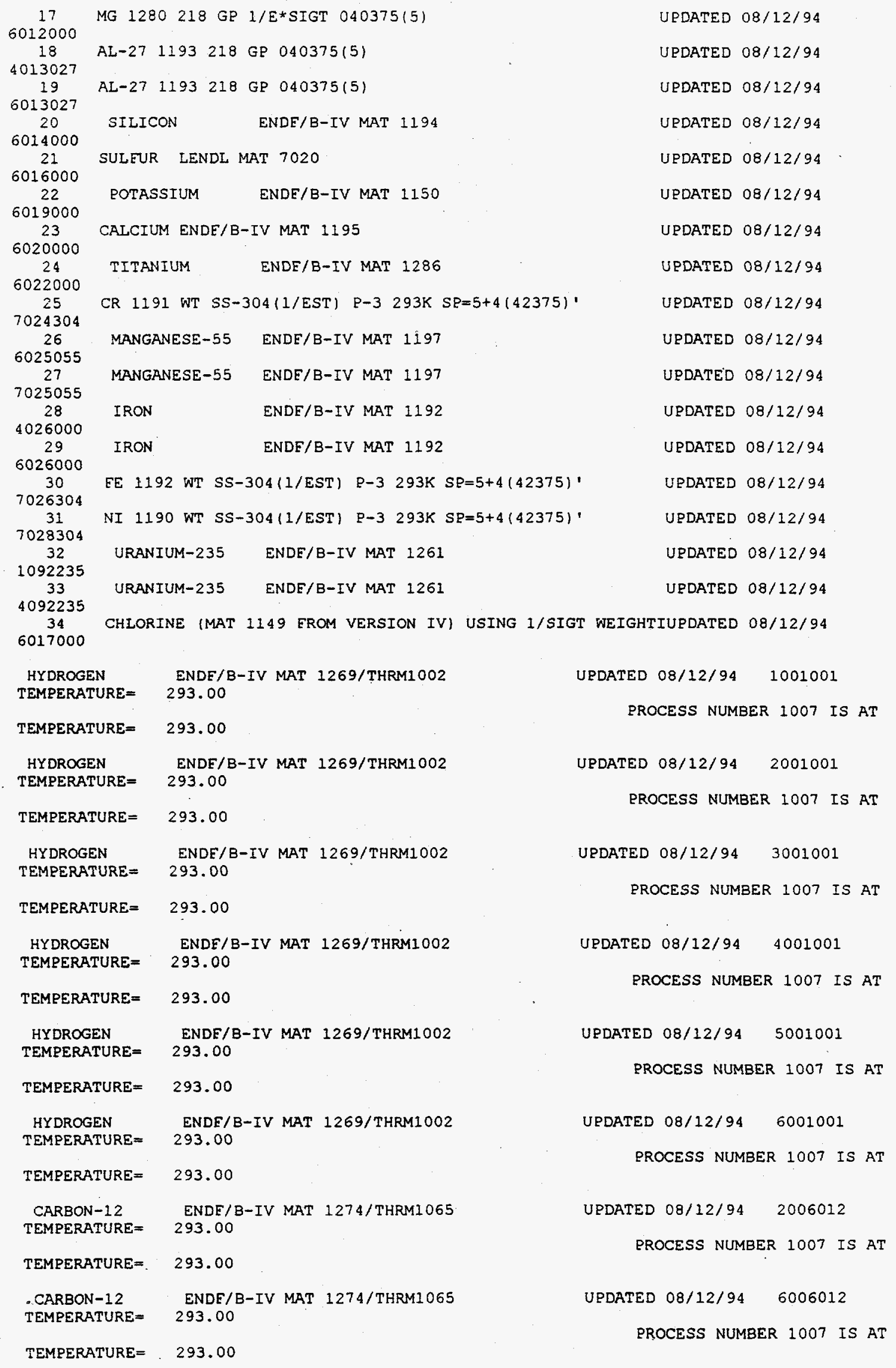




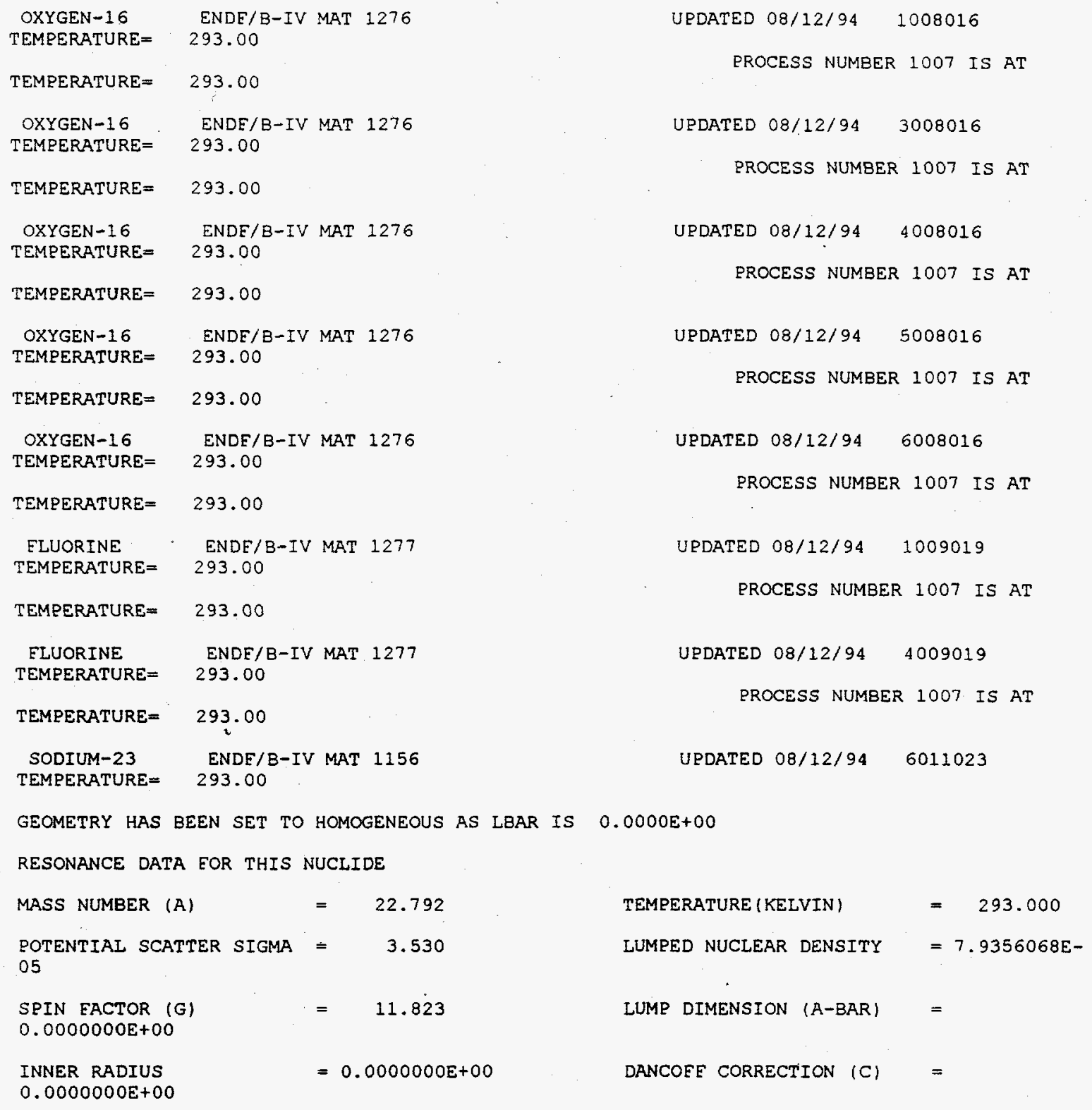


RESOLVED

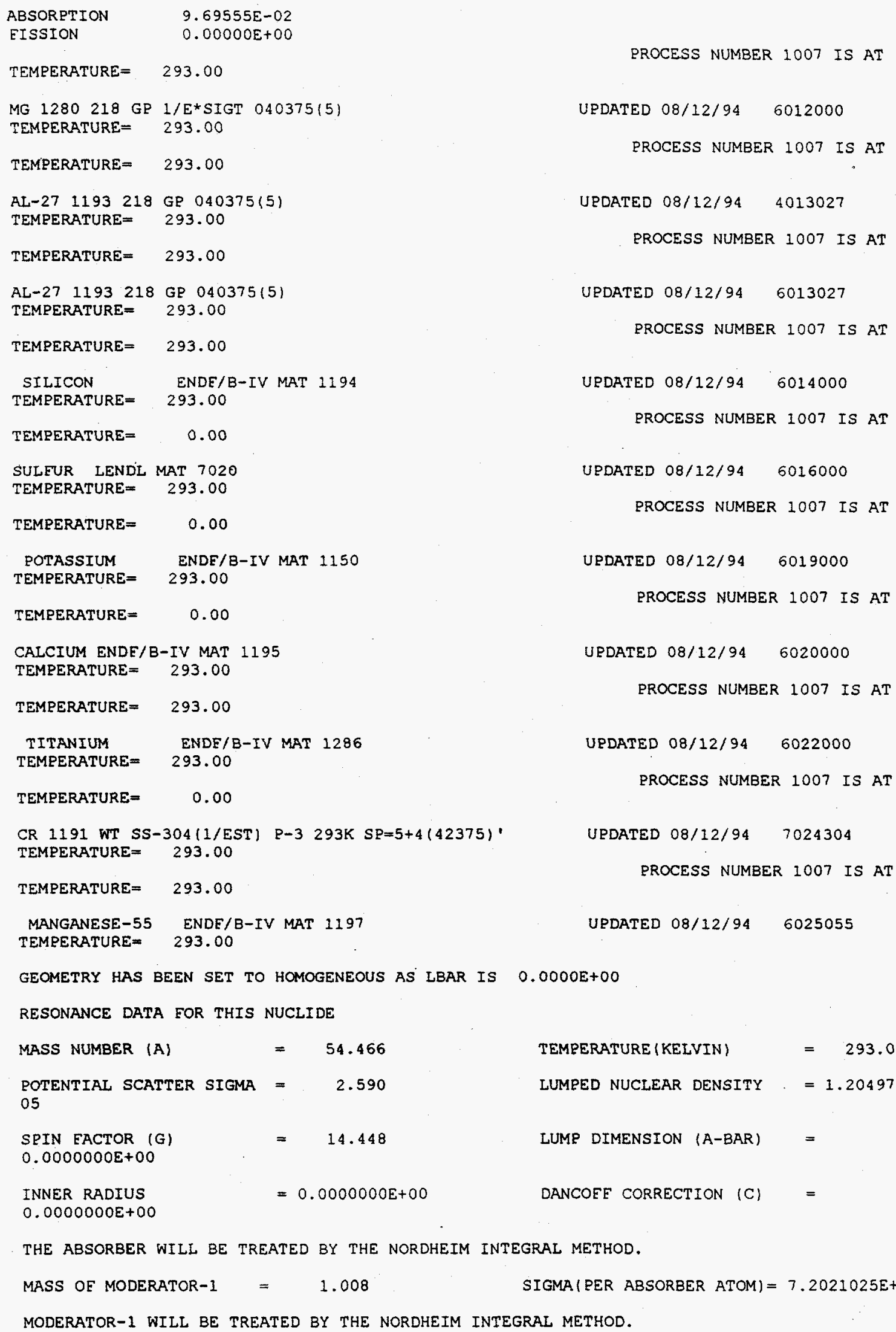

PROCESS NUMBER 1007 IS AT

UPDATED $08 / 12 / 94 \quad 6012000$

PROCESS NUMBER 1007 IS AT

UPDATED $08 / 12 / 94 \quad 4013027$

PROCESS NUMBER 1007 IS AT

UPDATED $08 / 12 / 94 \quad 6013027$

PROCESS NUMBER 1007 IS AT

UPDATED 08/12/94 6014000

PROCESS NUMBER 1007 IS AT

UPDATED $08 / 12 / 94 \quad 6016000$

PROCESS NUMBER 1007 IS AT

UPDATED $08 / 12 / 94 \quad 6019000$

PROCESS NUMBER 1007 IS AT

UPDATED 08/12/94 6020000

PROCESS NUMBER 1007 IS AT

UPDATED $08 / 12 / 94 \quad 6022000$

PROCESS NUMBER 1007 IS AT

UPDATED 08/12/94 7024304

PROCESS NUMBER 1007 IS AT

UPDATED $08 / 12 / 94 \quad 6025055$ 
MASS OE MODERATOR-2 $=16.328 \quad$ SIGMA $($ PER ABSORBER ATOM $)=2.1326717 \mathrm{E}+04$ MODERATOR-2 WILL BE TREATED BY THE NORDHEIM INTEGRAL METHOD.

THIS RESONANCE MATERIAL WILL BE TREATED AS A O-DIMENSIONAL OBJECT.

VOLUME ERACTION OF LUMP IN CELL USED TO ACCOUNT EOR SPATIAL SELE-SHIELDING 1.00000

$\begin{array}{cccc}\text { GROUP } & \text { RES ABS } & \text { RES EISS } & \text { RES SCAT } \\ 8 & -7.584859 E-06 & 0.000000 E+00 & -4.388205 E-03 \\ 9 & -2.174919 E-05 & 0.000000 E+00 & -1.963177 E-02 \\ 10 & -1.112325 E-02 & 0.000000 E+00 & -5.566122 E-01 \\ 11 & -8.937288 E-02 & 0.000000 E+00 & -4.057405 E+00\end{array}$

EXCESS RESONANCE INTEGRALS

RESOLVED

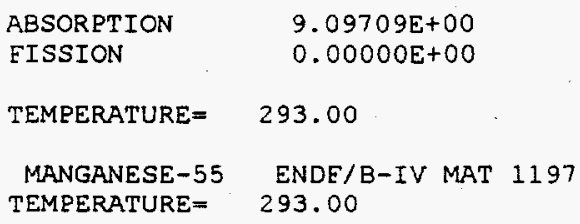




\begin{tabular}{|c|c|c|c|}
\hline MASS NUMBER (A) & 55.365 & TEMPERATURE (KELVIN) & $=293.000$ \\
\hline $\begin{array}{l}\text { POTENTIAL SCATTER SIGMA } \\
02\end{array}$ & 2.659 & LUMPED NUCLEAR DENSITY & $=1.7000001 \mathrm{E}-$ \\
\hline $\begin{array}{l}\text { SPIN EACTOR (G) } \\
0.0000000 E+00\end{array}$ & 0.748 & LUMR DIMENSION (A-BAR) & $=$ \\
\hline $\begin{array}{l}\text { INNER RADIUS } \\
0.0000000+00\end{array}$ & $=0.0000000 E+00$ & DANCOFE CORRECTION (C) & $=$ \\
\hline
\end{tabular}

MASS OF MODERATOR-1 $=1.008 \quad$ SIGMA(PER ABSORBER ATOM) $=1.4286198 \mathrm{E}+01$

MODERATOR-1 WILL BE TREATED BY THE NORDHEIM INTEGRAL METHOD.

MASS OE MODERATOR-2 $=22.298 \quad$ SIGMA(PER ABSORBER ATOM) $=4.3837705 E+00$

MODERATOR-2 WILL BE TREATED BY THE NORDHEIM INTEGRAL METHOD.

THIS RESONANCE MATERIAL WILL BE TREATED AS A O-DIMENSIONAL OBJECT.

VOLUME FRACTION OF LUMP IN CELI USED TO ACCOUNT EOR SPATIAL SELF-SHIEIDING $=1.00000$

$\begin{array}{cccc}\text { GROUP } & \text { RES ABS } & \text { RES EISS } & \text { RES SCAT } \\ 8 & -5.400211 \mathrm{E}-04 & 0.000000 \mathrm{E}+00 & -1.303678 \mathrm{E}+00 \\ 9 & -3.998998 \mathrm{E}-04 & 0.000000 \mathrm{E}+00 & -1.905708 \mathrm{E}-01 \\ 10 & 2.853071 \mathrm{E}-08 & 0.000000 \mathrm{E}+00 & -2.581987 \mathrm{E}-06\end{array}$

EXCESS RESONANCE INTEGRALS

RESOLVED

$\begin{array}{lccc}\text { ABSORPTION } & 2.11414 \mathrm{E}-02 & & \\ \text { FISSION } & 0.00000 \mathrm{E}+00 & & \\ \text { TEMPERATURE }= & 293.00 & \text { PROCESS NUMBER } 1007 \text { IS AT } \\ \text { IRON } & \text { ENDF } / \text { B-IV MAT } 1192 & \text { UPDATED } 08 / 12 / 94 & 6026000 \\ \text { TEMPERATURE }= & 293.00 & \end{array}$

GEOMETRY HAS BEEN SET TO HOMOGENEOUS AS LBAR IS $0.0000 E+00$

RESONANCE DATA FOR THIS NUCLIDE

$\begin{array}{lllll}\text { MASS NUMBER (A) } & =55.365 & \text { TEMPERATURE (KELVIN) } & = & 293.000 \\ \text { POTENTIAL SCATTER SIGMA } & = & 2.659 & \text { LUMPED NUCLEAR DENSITY } & =1.2953907 E- \\ 04 & = & 0.748 & \text { LUMP DIMENSION }(A-B A R) & = \\ \begin{array}{l}\text { SPIN EACTOR (G) } \\ 0.0000000 E+00\end{array} & & \text { DANCOEF CORRECTION (C) }= \\ \text { INNER RADIUS } & & & \end{array}$

THE ABSORBER WILL BE TREATED BY THE NORDHEIM INTEGRAL METHOD.

MASS OE MODERATOR-1 $=1.008 \quad$ SIGMA (PER ABSORBER ATOM $)=6.6994250 E+02$

MODERATOR-1 WILL BE TREATED BY THE NORDHEIM INTEGRAL METHOD.

MASS OF MODERATOR-2 $=16.270 \quad$ SIGMA (PER ABSORBER ATOM) $=1.9740624 E+03$

MODERATOR-2 WILL BE TREATED BY THE NORDHEIM INTEGRAL METHOD.

THIS RESONANCE MATERIAL WILL BE TREATED AS A O-DIMENSIONAL OBJECT.

VOLUME ERACTION OE LUMP IN CELL USED TO ACCOUNT EOR SPATIAL SELE-SHIELDING=1.00000

$\begin{array}{cccc}\text { GROUP } & \text { RES ABS } & \text { RES FISS } & \text { RES SCAT } \\ 8 & -1.379277 E-05 & 0.000000 E+00 & -2.653044 \mathrm{E}-02 \\ 9 & -5.431981 \mathrm{E}-06 & 0.000000 \mathrm{E}+00 & -2.347404 \mathrm{E}-03 \\ 10 & 2.148488 \mathrm{E}-09 & 0.000000 \mathrm{E}+00 & -2.730928 \mathrm{E}-07\end{array}$


EXCESS RESONANCE INTEGRALS

RESOLVED

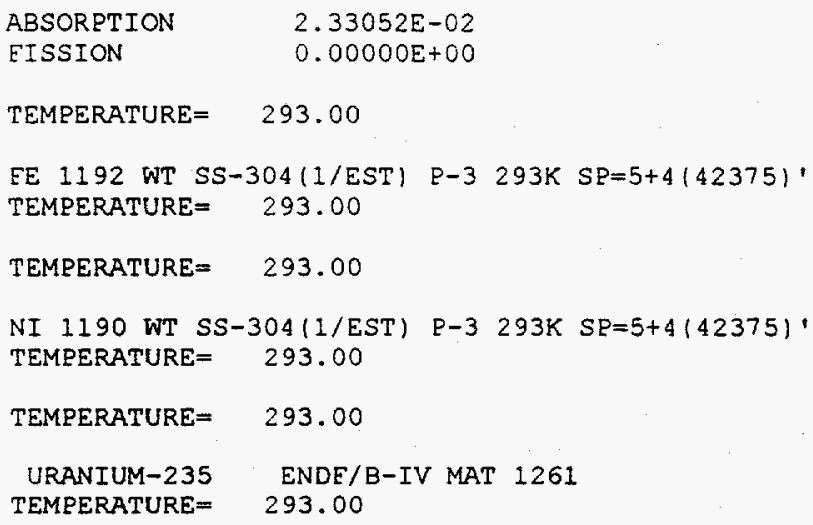

THE ABSORBER WILL BE TREATED BY THE NORDHEIM INTEGRAL METHOD.

MASS OF MODERATOR-1 $=1.008 \quad$ SIGMA(PER ABSORBER ATOM) $=7.5230469 \mathrm{E}+03$ MODERATOR-1 WILL BE TREATED BY THE NORDHEIM INTEGRAL METHOD.

MASS OE MODERATOR-2 $=16.016 \quad$ SIGMA(PER ABSORBER ATOM) $=7.3244318 E+02$ MODERATOR-2 WILL BE TREATED BY THE NORDHEIM INTEGRAL METHOD.

THIS RESONANCE MATERIAL WILL BE TREATED AS A O-DIMENSIONAL OBJECT.

VOLUME ERACTION OF LUMP IN CELL USED TO ACCOUNT FOR SPATIAL SELF-SHIELDING=1.00000

$\begin{array}{cccr}\text { GROUP } & \text { RES ABS } & \text { RES EISS } & \text { RES SCAT } \\ 12 & -9.044416 \mathrm{E}-01 & -5.549288 \mathrm{E}-01 & -2.391155 \mathrm{E}-02 \\ 13 & -3.145243 \mathrm{E}+00 & -1.546129 \mathrm{E}+00 & -7.353358 \mathrm{E}-02 \\ 14 & -2.226849 \mathrm{E}+00 & -1.33914 \mathrm{E}+00 & -1.698238 \mathrm{E}-02 \\ 15 & -1.228059 \mathrm{E}-04 & -9.337281 \mathrm{E}-05 & 6.295855 \mathrm{E}-07\end{array}$

EXCESS RESONANCE INTEGRALS

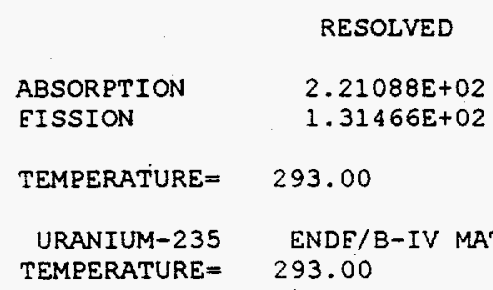




\section{$\mathrm{F}-34$}

$\begin{array}{llll}\text { POTENTIAL SCATTER SIGMA } & =11.500 & \text { LUMPED NUCLEAR DENSITY } & =3.2282845 E- \\ 05 & & & \\ \begin{array}{l}\text { SPIN EACTOR (G) } \\ 0.0000000 E+00\end{array} & \text { LUMR DIMENSION }(A-B A R) & = \\ \text { INNER RADIUS } & =0.0000000 E+00 & \text { DANCOFE CORRECTION (C) }= \\ 0.0000000 E+00 & & \end{array}$

THE ABSORBER WILL BE TREATED BY THE NORDHEIM INTEGRAL METHOD.

MASS OE MODERATOR-1 $=1.008$ SIGMA (PER ABSORBER ATOM) $=7.5230474 E+03$

MODERATOR-1 WILL BE TREATED BY THE NORDHEIM INTEGRAL METHOD.

MASS OF MODERATOR-2 $=38.504 \quad$ SIGMA (PER ABSORBER ATOM) $=7.6364658 E+03$

MODERATOR-2 WILL BE TREATED BY THE NORDHEIM INTEGRAL METHOD.

THIS RESONANCE MATERIAL WILL BE TREATED AS A O-DIMENSIONAL OBJECT.

VOLUME FRACTION OE LUMP IN CELL USED TO ACCOUNT EOR SPATIAI SELE-SHIELDING=1.00000

$\begin{array}{cccc}\text { GROUP } & \text { RES ABS } & \text { RES FISS } & \text { RES SCAT } \\ 12 & -5.092921 \mathrm{E}-01 & -3.125200 \mathrm{E}-01 & -1.243320 \mathrm{E}-02 \\ 13 & -1.847332 \mathrm{E}+00 & -9.110399 \mathrm{E}-01 & -3.932169 \mathrm{E}-02 \\ 14 & -1.357982 \mathrm{E}+00 & -8.222151 \mathrm{E}-01 & -7.465982 \mathrm{E}-03 \\ 15 & -1.181174 \mathrm{E}-04 & -8.954299 \mathrm{E}-05 & 7.257908 \mathrm{E}-07\end{array}$

EXCESS RESONANCE INTEGRALS

$$
\text { RESOLVED }
$$

ABSORPTION $\quad 2.24002 E+02$

EISSION $1.33058 E+02$

TEMPERATURE $=\quad 293.00$

PROCESS NUMBER 1007 IS AT

CHLORINE (MAT 1149 FROM VERSION IV) USING 1/SIGT WEIGHTIUPDATED 08/12/94 6017000 TEMPERATURE $=293.00$

TEMPERATURE $=\quad 300.00$

PROCESS NUMBER 1007 IS AT 
THIS XSDRN WORKING TAPE WAS CREATED 08/30/96 AT 22:07:52

THE TITLE OE THE PARENT CASE IS AS FOLLOWS

SCALE 4.2 - 27 GROUP NEUTRON GROUP LIBRARY

BASED ON ENDE-B VERSION 4 DATA

COMPILED FOR NRC $1 / 27 / 89$

TAPE ID

4321

NUMBER OF NEUTRON GROUPS

TABLE OE CONTENTS

1001001

HYDROGEN

269/THRMIOO2

2001001

HYDROGEN

ENDE/B-IV MAT 1269/THRM1002

3001001

HYDROGEN

ENDE/B-IV MAT 1269/THRM1002

HYDROGEN

ENDE/B-IV MAT 1269/THRM1002

4001001

HYDROGEN

ENDE/B-IV MAT 1269/THRM1002

5001001

HYDROGEN

ENDE/B-IV MAT 1269/THRM1002

6001001

CARBON-12

ENDE/B-IV MAT 1274/THRM1065

2006012

CARBON -12

ENDE/B-IV MAT 1274/THRM1065

6006012

1008016

OXYGEN-16

ENDE/B-IV MAT 1276

OXYGEN-16

ENDE/B-IV MAT 1276

3008016

OXYGEN-16

ENDE/B-IV MAT 1276

4008016

OXYGEN-16

ENDE/B-IV MAT 1276

5008016

OXYGEN-16

ENDE/B-IV MAT 1276

6008016

FLUORINE

ENDF/B-IV MAT 1277

1009019

ELUORINE

ENDE/B-IV MAT 1277

4009019

SODIUM-23

ENDE/B-IV MAT 1156

6011023

6012000

MG 1280218 GP $1 / E^{\star}$ SIGT 040375 (5)

AL-27 1193218 GP $040375(5)$

AL-27 $1193 \quad 218$ GP $040375(5)$

6013027

6014000

SILICON ENDE/B-IV MAT 1194

6016000

6019000

SULEUR LENDL MAT 7020

6020000

6022000

ROTASSIUM ENDE/B-IV MAT 1150

CALCIUM ENDE/B-IV MAT 1195

TITANIUM ENDE/B-IV MAT 1286

CR 1191 WT SS-304(1/EST) $P-3293 \mathrm{~K} \mathrm{SP}=5+4(42375)$ '

7024304

MANGANESE-55 ENDE/B-IV MAT 1197

6025055

7025055

MANGANESE-55 ENDE/B-IV MAT 1197

4026000

IRON

ENDE/B-IV MAT 1192

6026000

IRON ENDE/B-IV MAT 1192

FE 1192 WT SS-304(1/EST) $P-3 \quad 293 K S P=5+4(42375)$ 7026304

7028304

NI 1190 WT SS-304(1/EST) P-3 $293 \mathrm{~K} S \mathrm{P}=5+4(42375)^{\prime}$

1092235

URANIUM-235 ENDE/B-IV MAT 1261

\begin{tabular}{|c|c|}
\hline UPDATED & $08 / 12 / 94$ \\
\hline UPDATED & $08 / 12 / 94$ \\
\hline UPDATED & $08 / 12 / 94$ \\
\hline UPDATED & $08 / 12 / 94$ \\
\hline UPDATED & $08 / 12 / 94$ \\
\hline UPDATED & $08 / 12 / 94$ \\
\hline UPDATED & $08 / 12 / 94$ \\
\hline UPDATED & $08 / 12 / 94$ \\
\hline UPDATED & $08 / 12 / 94$ \\
\hline UPDATED & $08 / 12 / 94$ \\
\hline UPDATED & $08 / 12 / 94$ \\
\hline UPDATED & $08 / 12 / 94$ \\
\hline UPDATED & $08 / 12 / 94$ \\
\hline UPDATED & $08 / 12 / 94$ \\
\hline UPDATED & $08 / 12 / 94$ \\
\hline UPDATED & $08 / 12 / 94$ \\
\hline UPDATED & $08 / 12 / 94$ \\
\hline UPDATED & $08 / 12 / 94$ \\
\hline UPDATED & $08 / 12 / 94$ \\
\hline UPDATED & $08 / 12 / 94$ \\
\hline UPDATED & $08 / 12 / 94$ \\
\hline UPDATED & $08 / 12 / 94$ \\
\hline UPDATED & $08 / 12 / 94$ \\
\hline UPDATED & $08 / 12 / 94$ \\
\hline UPDATED & $08 / 12 / 94$ \\
\hline UPDATED & $08 / 12 / 94$ \\
\hline UPDATED & $08 / 12 / 94$ \\
\hline UPDATED & $08 / 12 / 94$ \\
\hline UPDATED & $08 / 12 / 94$ \\
\hline UPDATED & $08 / 12 / 94$ \\
\hline UPDATED & $08 / 12 / 94$ \\
\hline UPDATED & $08 / 12 / 94$ \\
\hline
\end{tabular}

NUMBER OF GAMMA GROUPS

LOGICAL UNIT 
4092235

URANIUU:-235 ENDE/B-IV MAT 1261

URDATED $08 / 12 / 94$

ID 6017000

CHLORINE (MAT 1149 FROM VERSION IV) USING 1/SIGT WEIGHTIUPDATED 08/12/94

TAPE COPY USED

O I/O'S, AND TOOK

9.44 SECONDS 


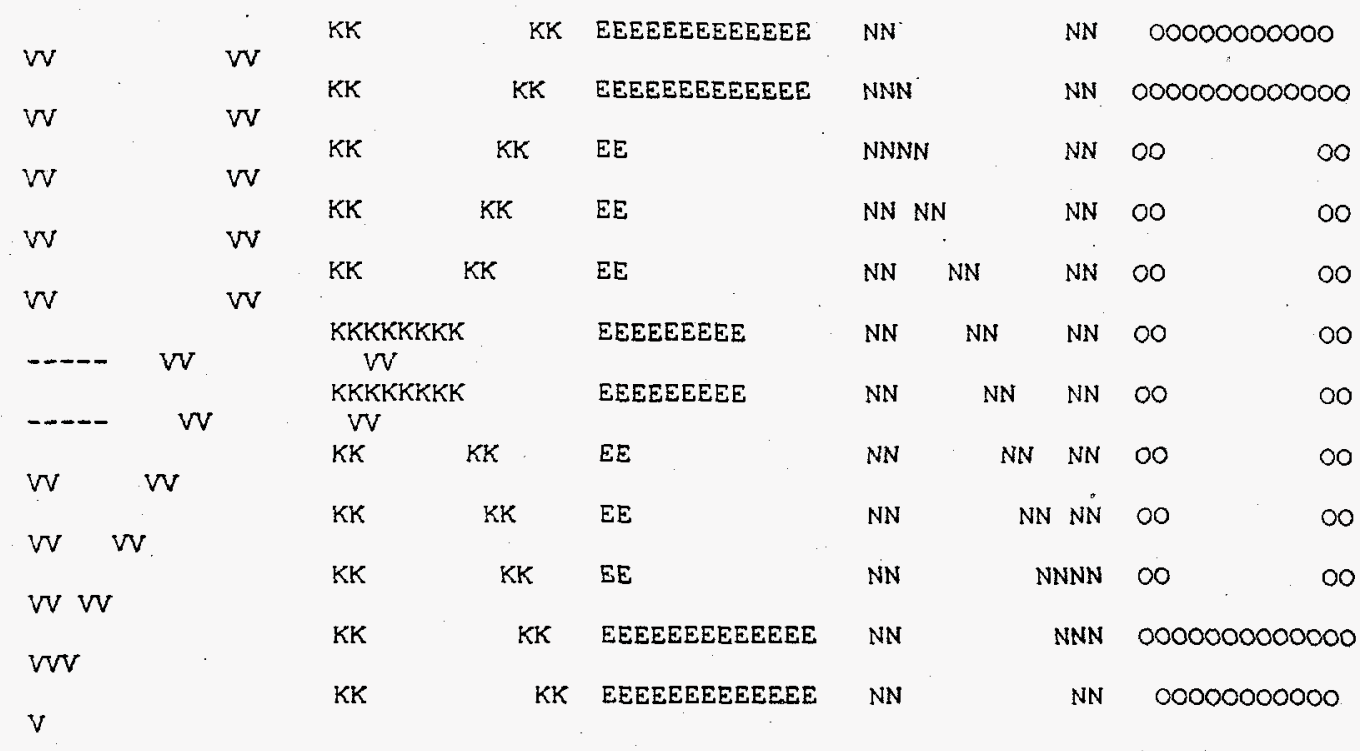

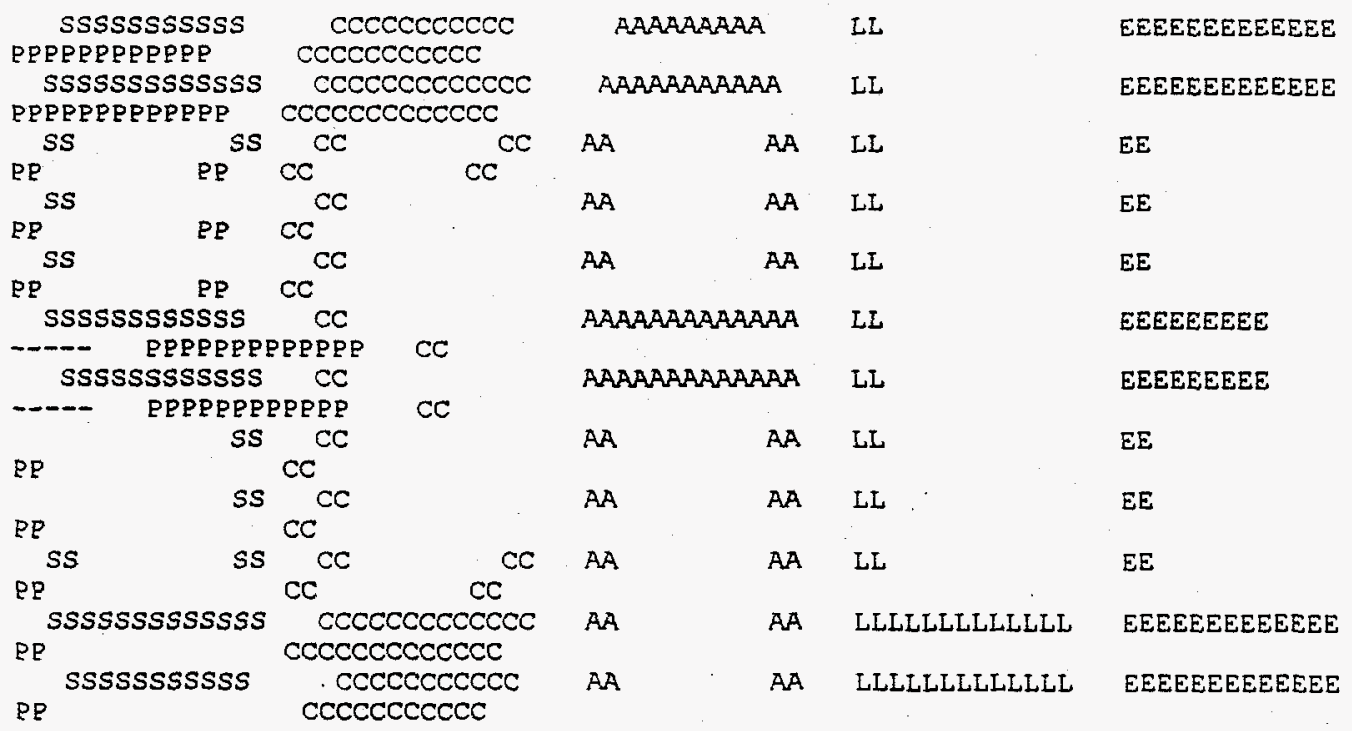

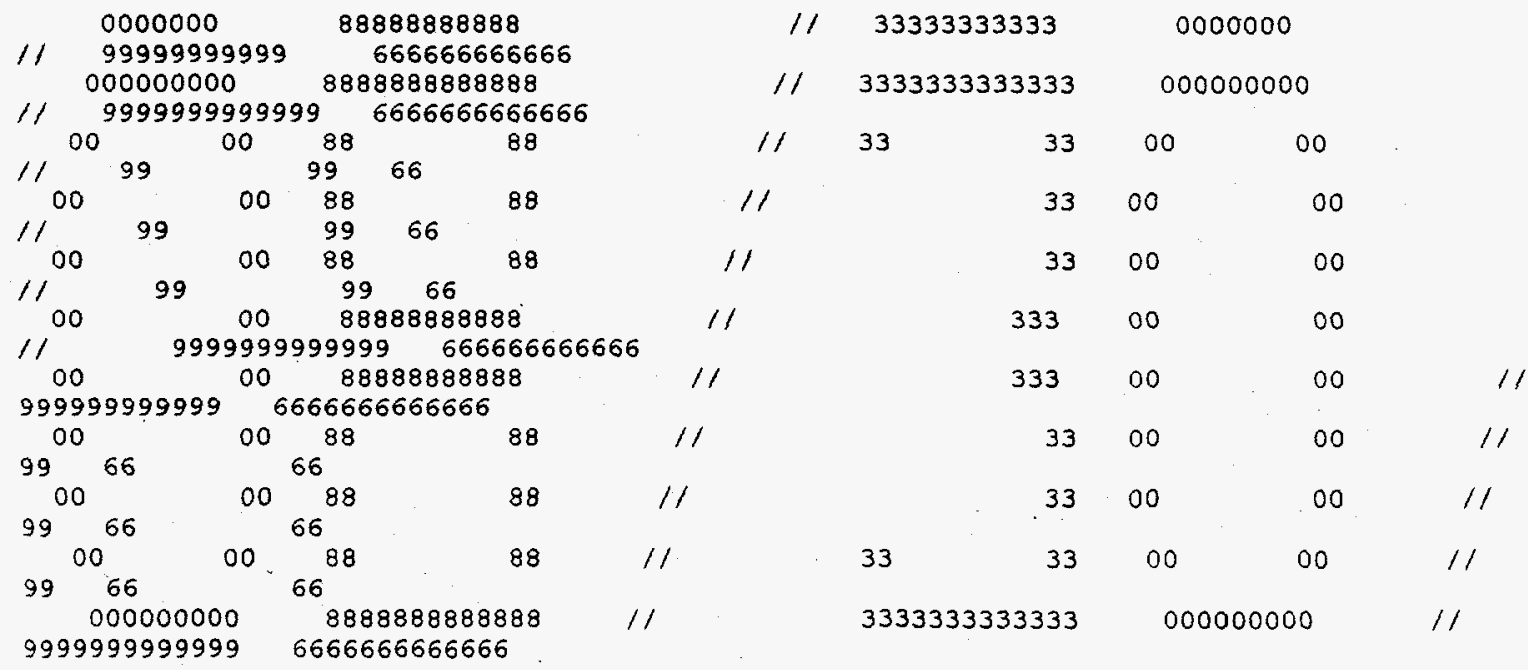




\section{F-38}

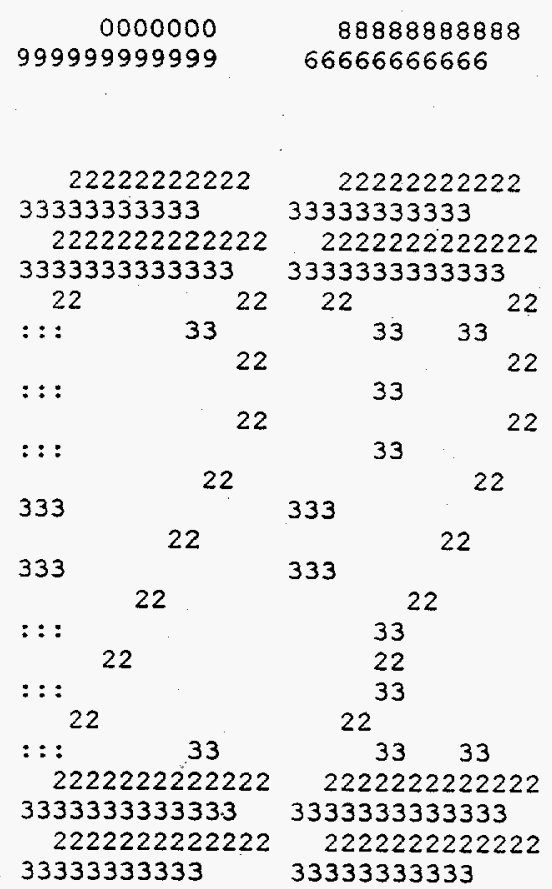

11

33333333333

0000000

11

33333333333

\begin{tabular}{|c|c|c|c|c|c|}
\hline & & \multicolumn{2}{|c|}{0000000} & \multicolumn{2}{|c|}{88888888888} \\
\hline & & \multicolumn{2}{|c|}{000000000} & \multicolumn{2}{|c|}{8888888888888} \\
\hline \multicolumn{6}{|c|}{3} \\
\hline 33 & $:::$ & 00 & 00 & 88 & 88 \\
\hline \multirow{3}{*}{33} & $:::$ & 00 & 00 & 88 & 88 \\
\hline & & 00 & 00 & \multicolumn{2}{|c|}{88888888888} \\
\hline & " & 00 & 00 & \multicolumn{2}{|c|}{88888888888} \\
\hline 33 & $::$ : & 00 & 00 & 88 & 88 \\
\hline 33 & $:::$ & 00 & 00 & 88 & 88 \\
\hline 33 & $:::$ & 00 & 00 & 88 & 88 \\
\hline & & \multicolumn{2}{|c|}{000000000} & \multicolumn{2}{|c|}{8888888888888} \\
\hline & & \multicolumn{2}{|c|}{0000000} & & \\
\hline
\end{tabular}




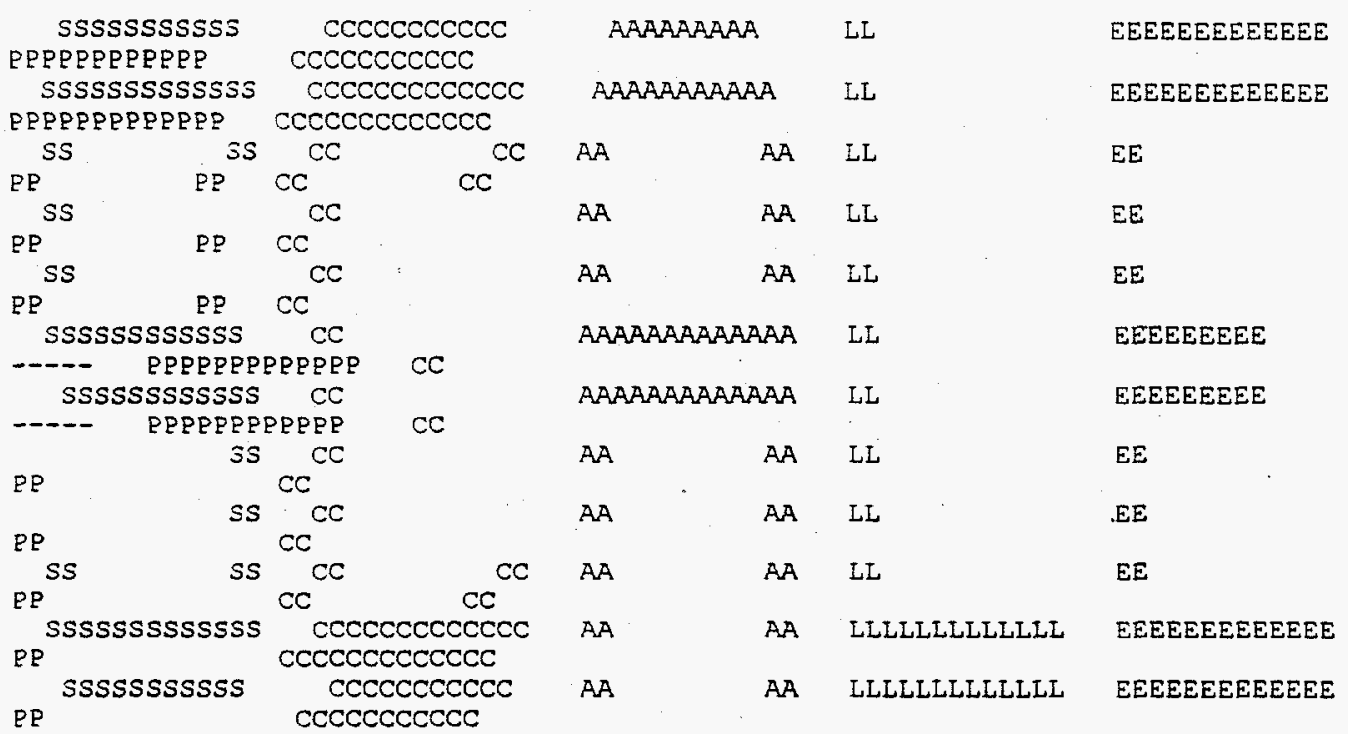

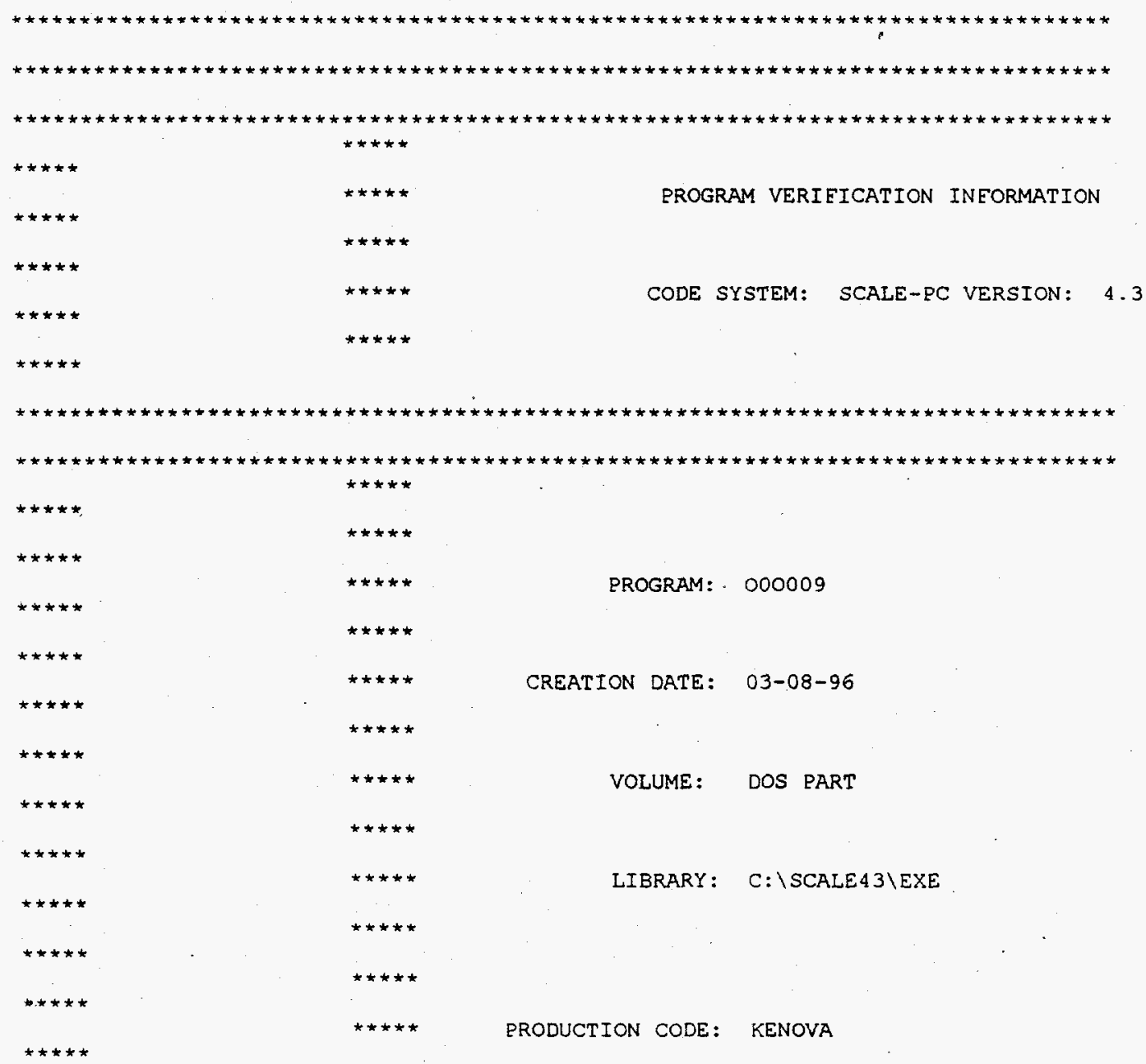




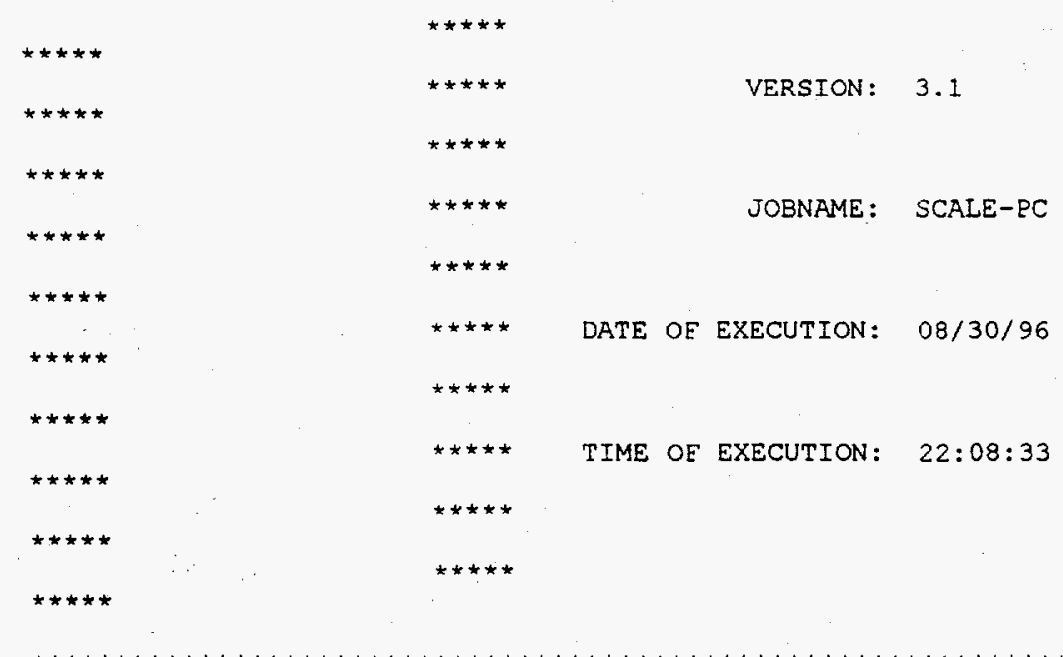


F-41

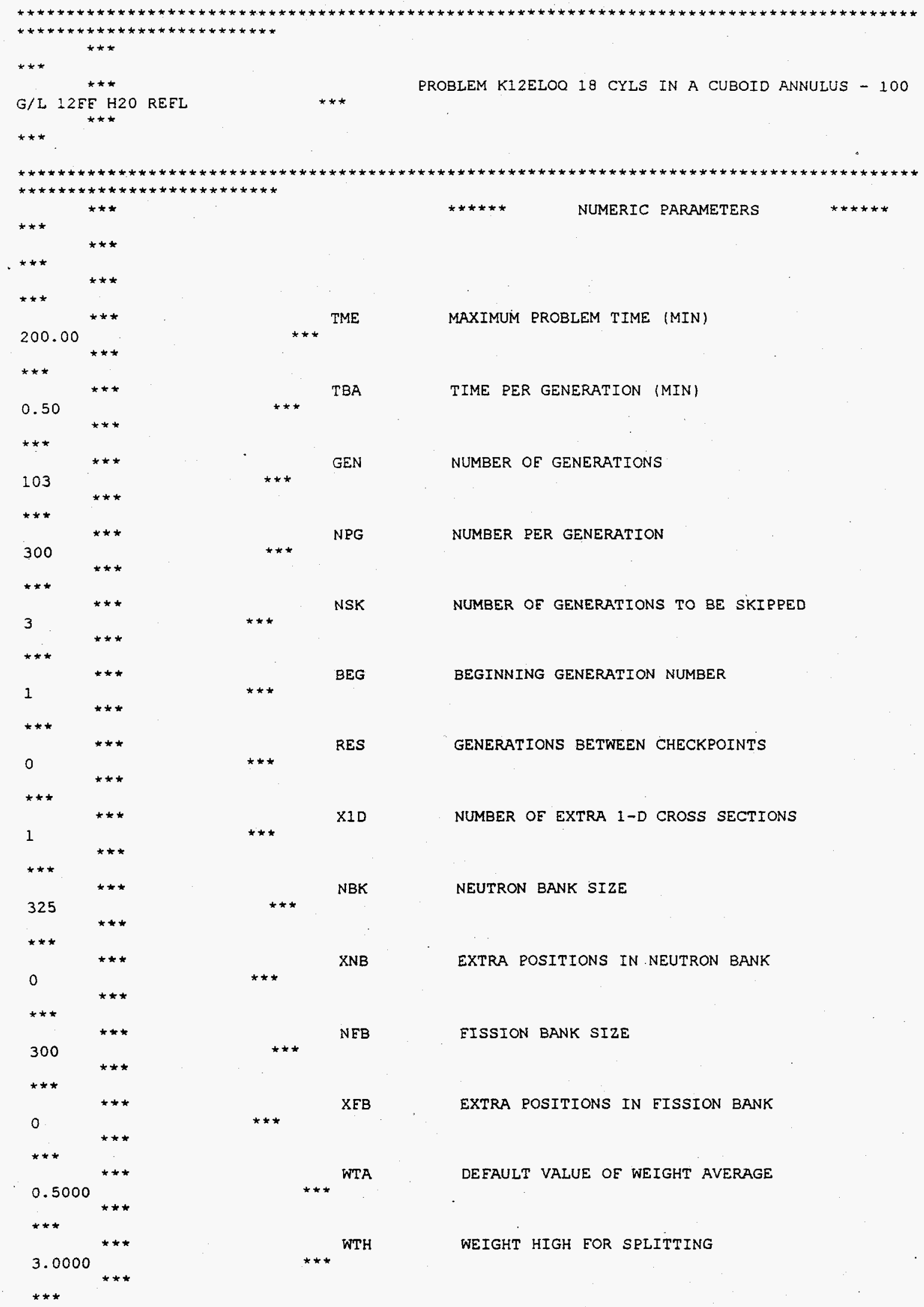




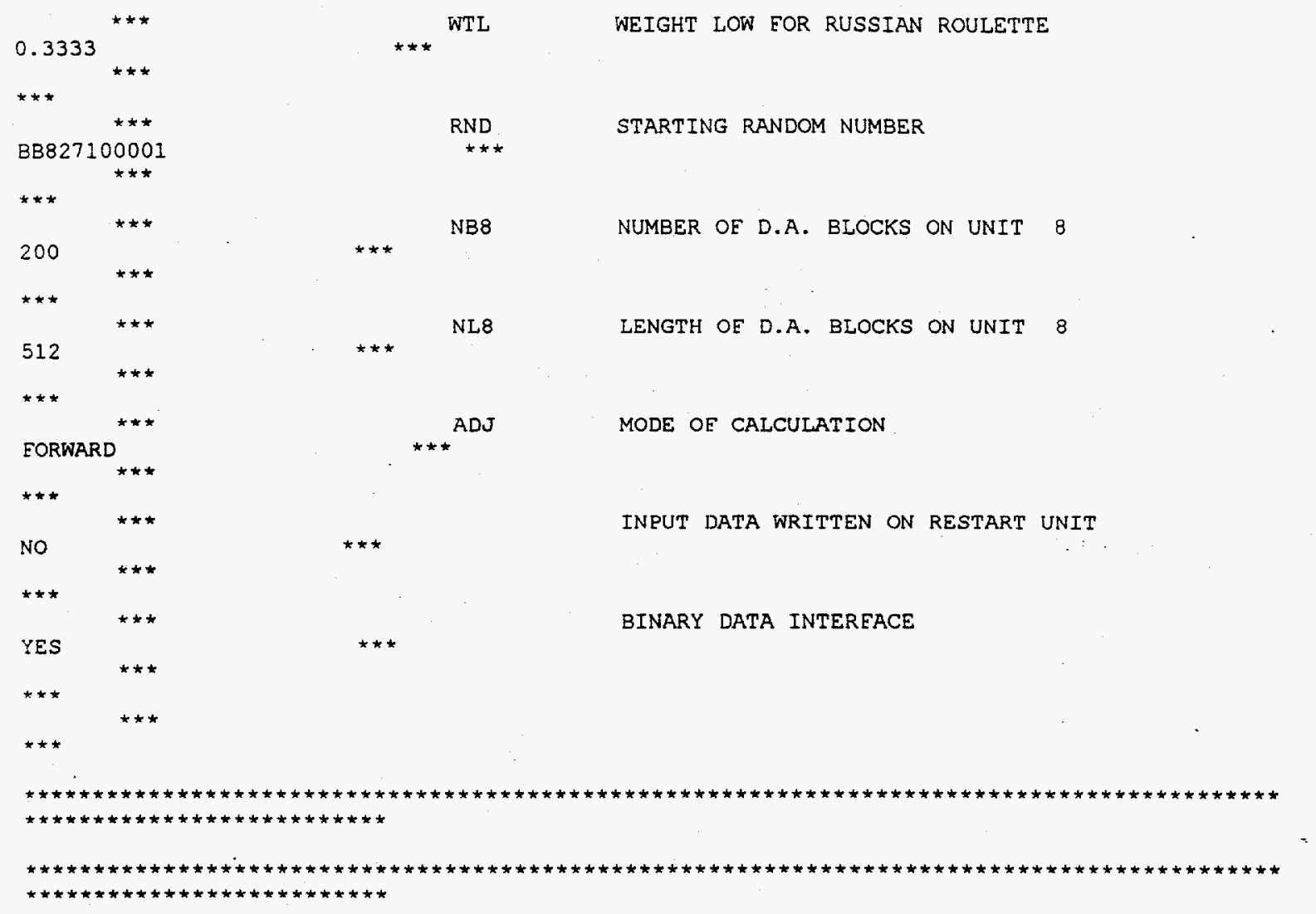




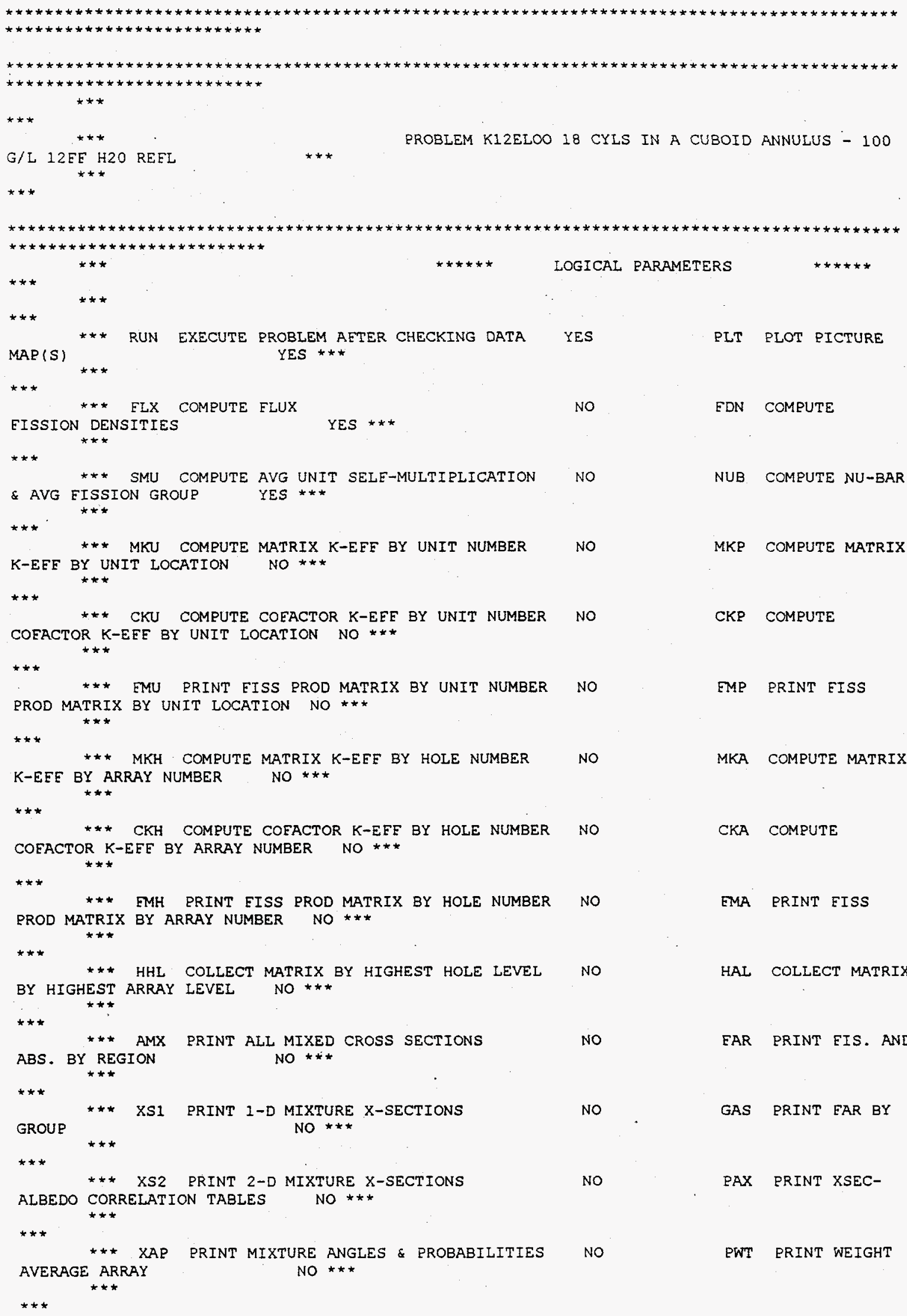




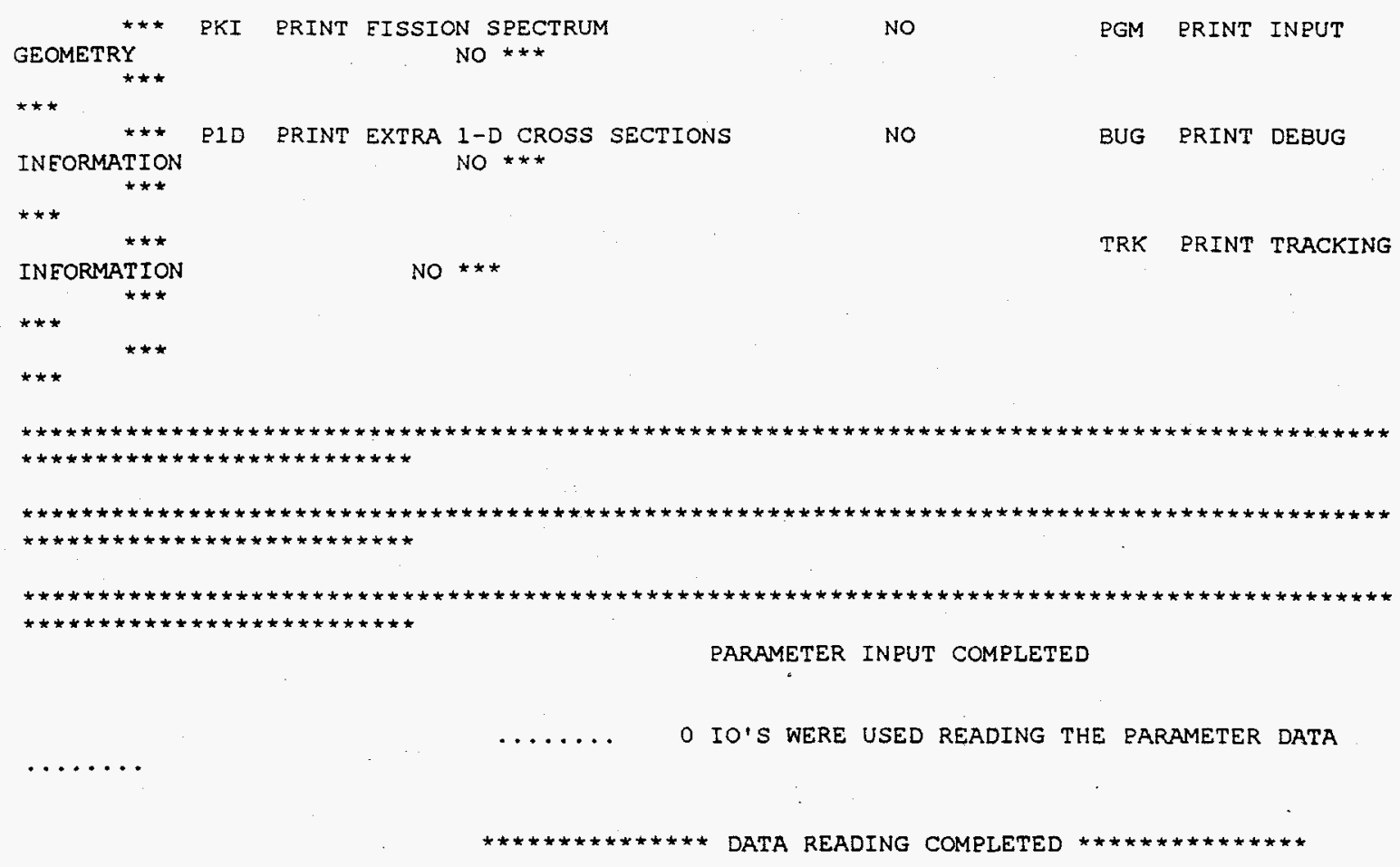




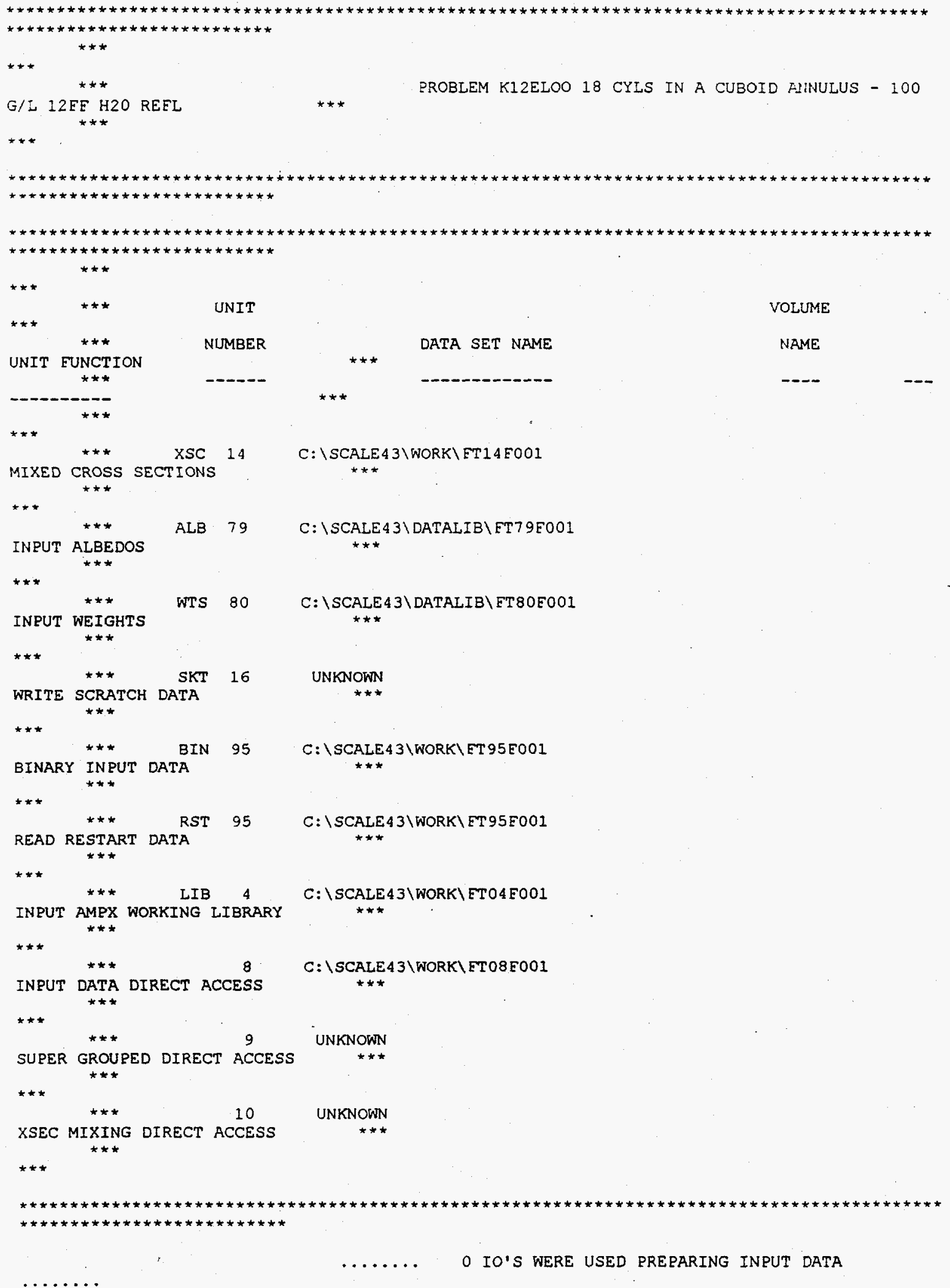


G/L 12FE H2O REEL

PROBLEM K12ELOO 18 CYLS IN A CUBOID ANNULUS - 100

MIXING TABLE

NUMBER OF SCATTERING ANGLES $=2$

CROSS SECTION MESSAGE THRESHOLD $=3$. OE-05

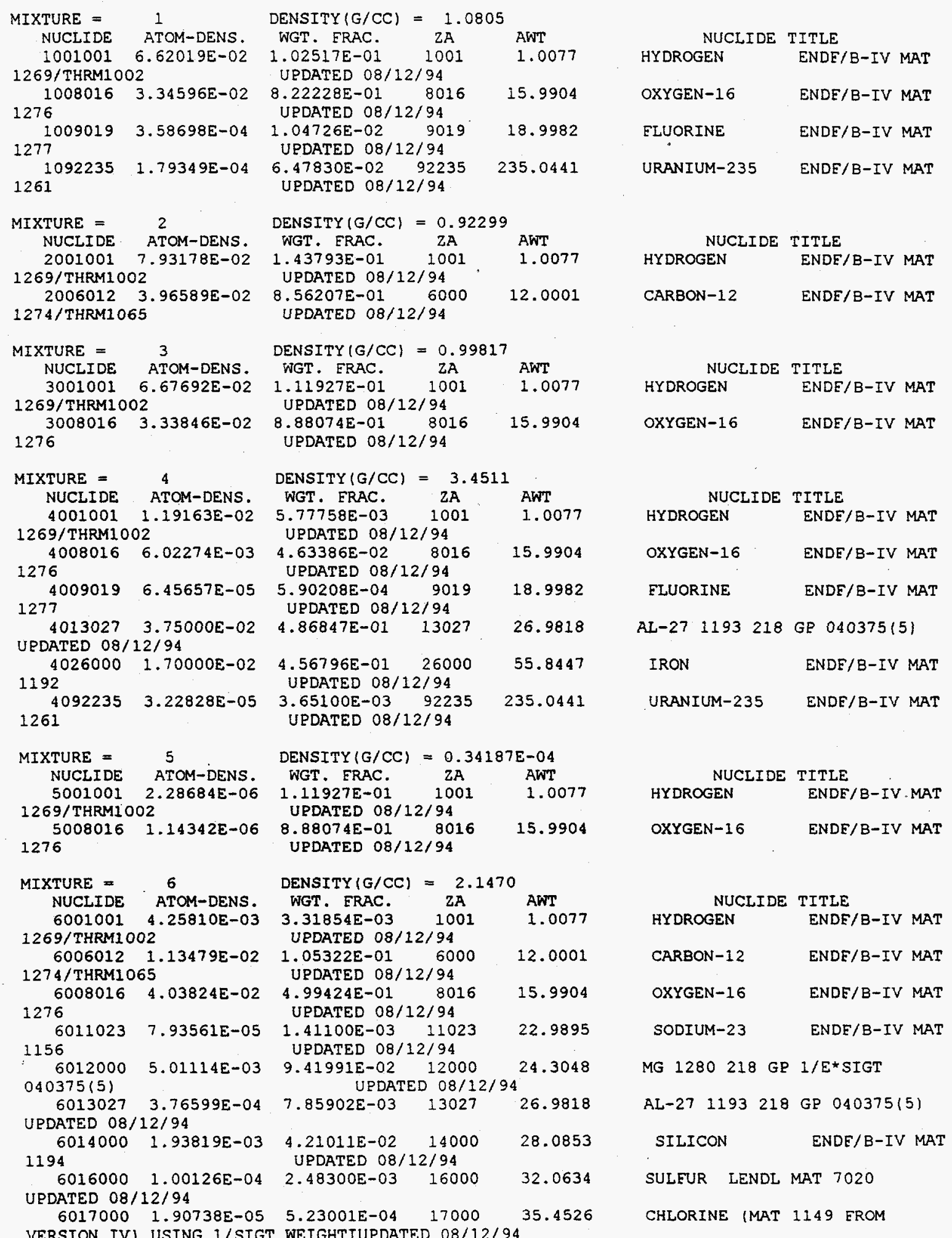




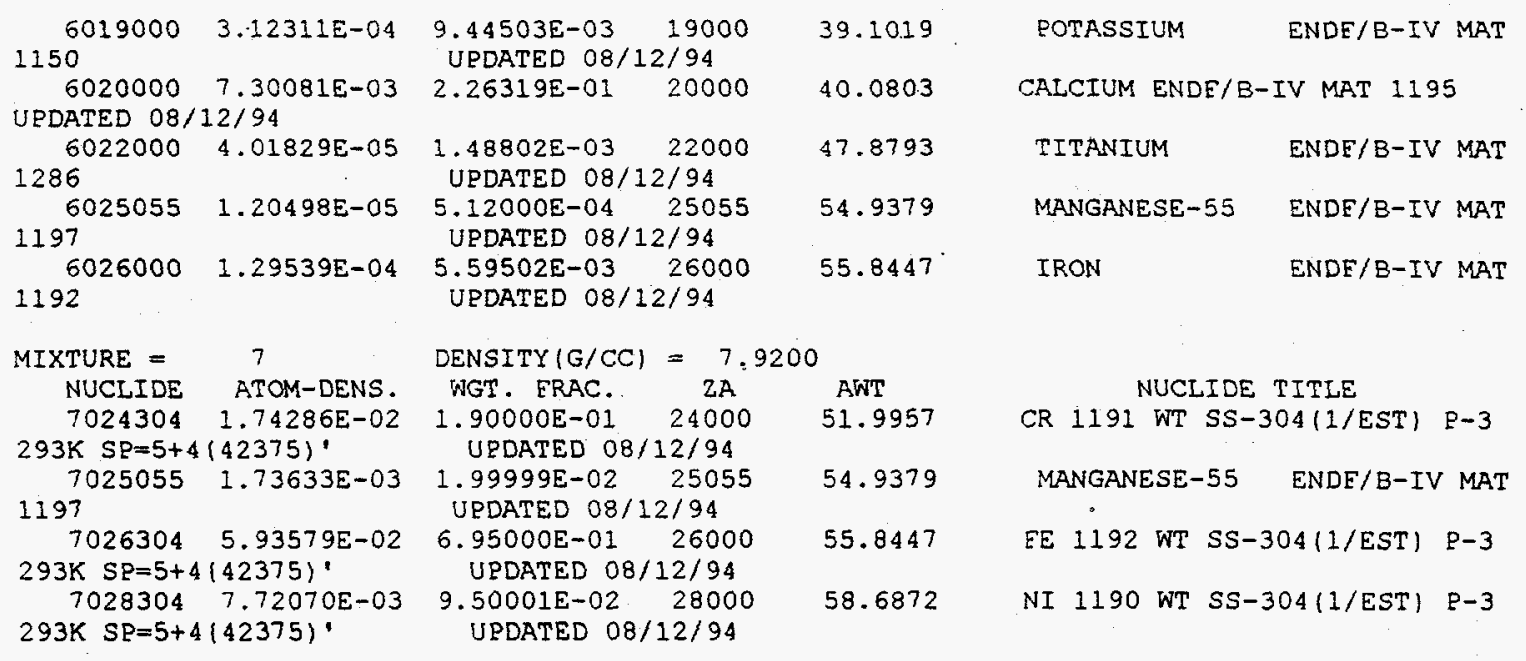

$$
\begin{aligned}
& \text { URDATED 08/12/94 } \\
& \text { UPDATED 08/12/94 } \\
& \text { URDATED 08/12/94 } \\
& \text { UPDATED 08/12/94 } \\
& \text { UPDATED 08/12/94 } \\
& \text { UPDATED 08/12/94 } \\
& \text { UPDATED 08/12/94 } \\
& \text { UPDATED 08/12/94 } \\
& \text { UPDATED 08/12/94 } \\
& \text { UPDATED 08/12/94 } \\
& \text { UPDATED } 08 / 12 / 94 \\
& \text { UPDATED 08/12/94 } \\
& \text { UPDATED 08/12/94 } \\
& \text { URDATED } 08 / 12 / 94 \\
& \text { UPDATED 08/12/94 } \\
& \text { UPDATED 08/12/94 } \\
& \text { UPDATED 08/12/94 } \\
& \text { UPDATED 08/12/94 } \\
& \text { UPDATED } 08 / 12 / 94 \\
& \text { UPDATED 08/12/94 } \\
& \text { UPDATED 08/12/94 } \\
& \text { UPDATED 08/12/94 } \\
& \text { UPDATED } 08 / 12 / 94 \\
& \text { UPDATED 08/12/94 } \\
& \text { UPDATED 08/12/94 } \\
& \text { UPDATED } 08 / 12 / 94
\end{aligned}
$$

ENDE/B-IV MAT 1269/THRM1002

ENDE/B-IV MAT 1269/THRM1002

ENDE/B-IV MAT 1269/THRMI002

ENDE/B-IV MAT 1269/THRM1002

ENDF/B-IV MAT 1269/THRM1002

ENDE/B-IV MAT 1269/THRM1002

ENDE/B-IV MAT 1274/THRM1065

ENDE/B-IV MAT 1274/THRM1065

ENDE/B-IV MAT 1276

ENDE/B-IV MAT 1276

ENDE/B-IV MAT 1276

ENDF/B-IV MAT 1276

ENDE/B-IV MAT 1276

ENDE/B-IV MAT 1277

ENDF/8-IV MAT 1277

ENDE/B-IV MAT 1156

6012000 MG $1280218 \mathrm{GP} 1 / E \star S I G T ~ 040375(5)$

4013027 AL-27 1193218 GP $040375(5)$

6013027 AL-27 1193218 GP $040375(5)$

6014000 SILICON ENDE/B-IV MAT 1194

6016000 SULEUR LENDL MAT 7020

6019000 POTASSIUM ENDE/B-IV MAT 1150

6020000 CALCIUM ENDE/B-IV MAT 1195

6022000 TITANIUM ENDE/B-IV MAT 1286

7024304 CR 1191 WT SS-304(1/EST) $P-3 \quad 293 K \quad S P=5+4(42375)^{\prime}$

6025055 MANGANESE-55 ENDE/B-IV MAT 1197 


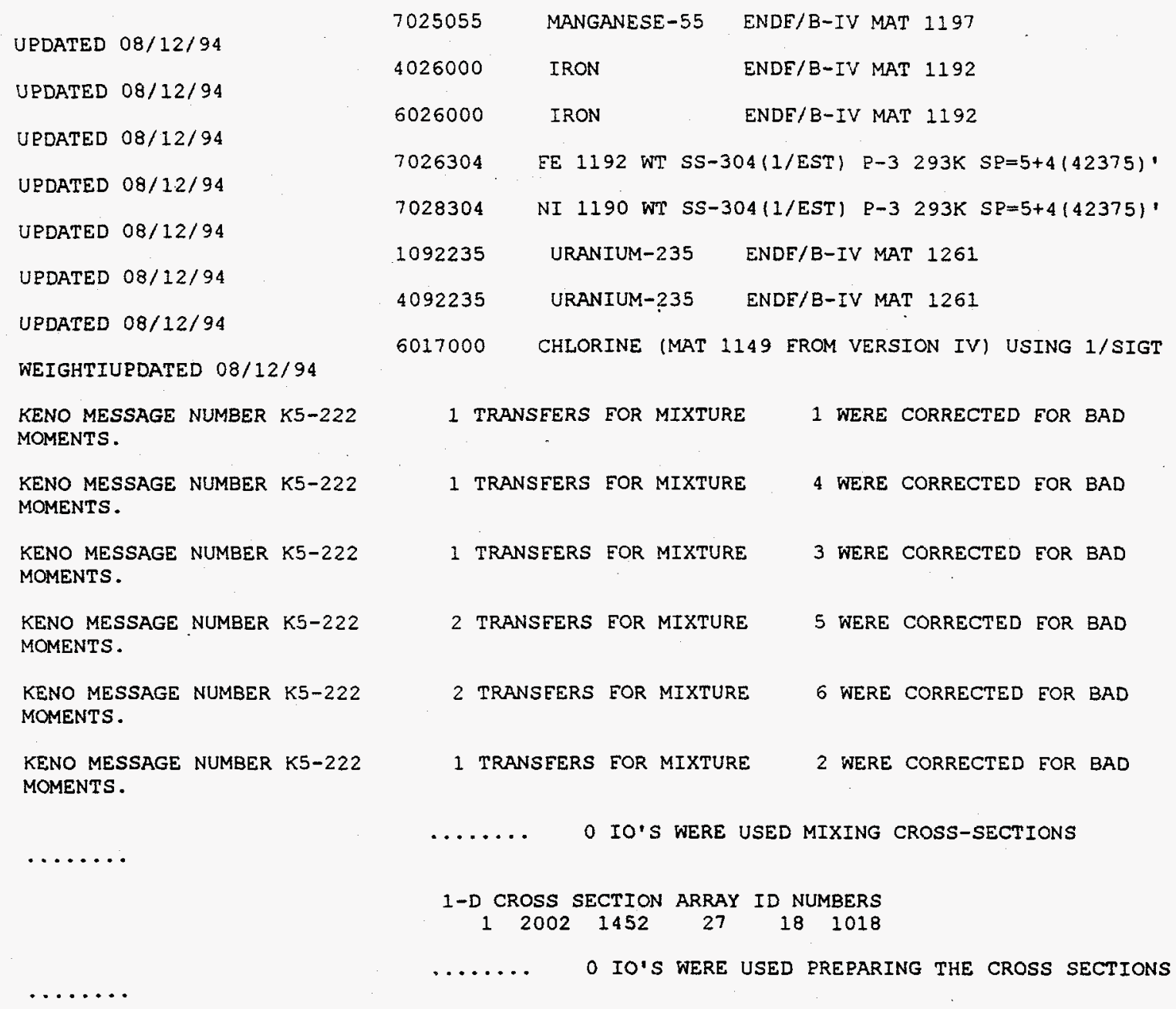




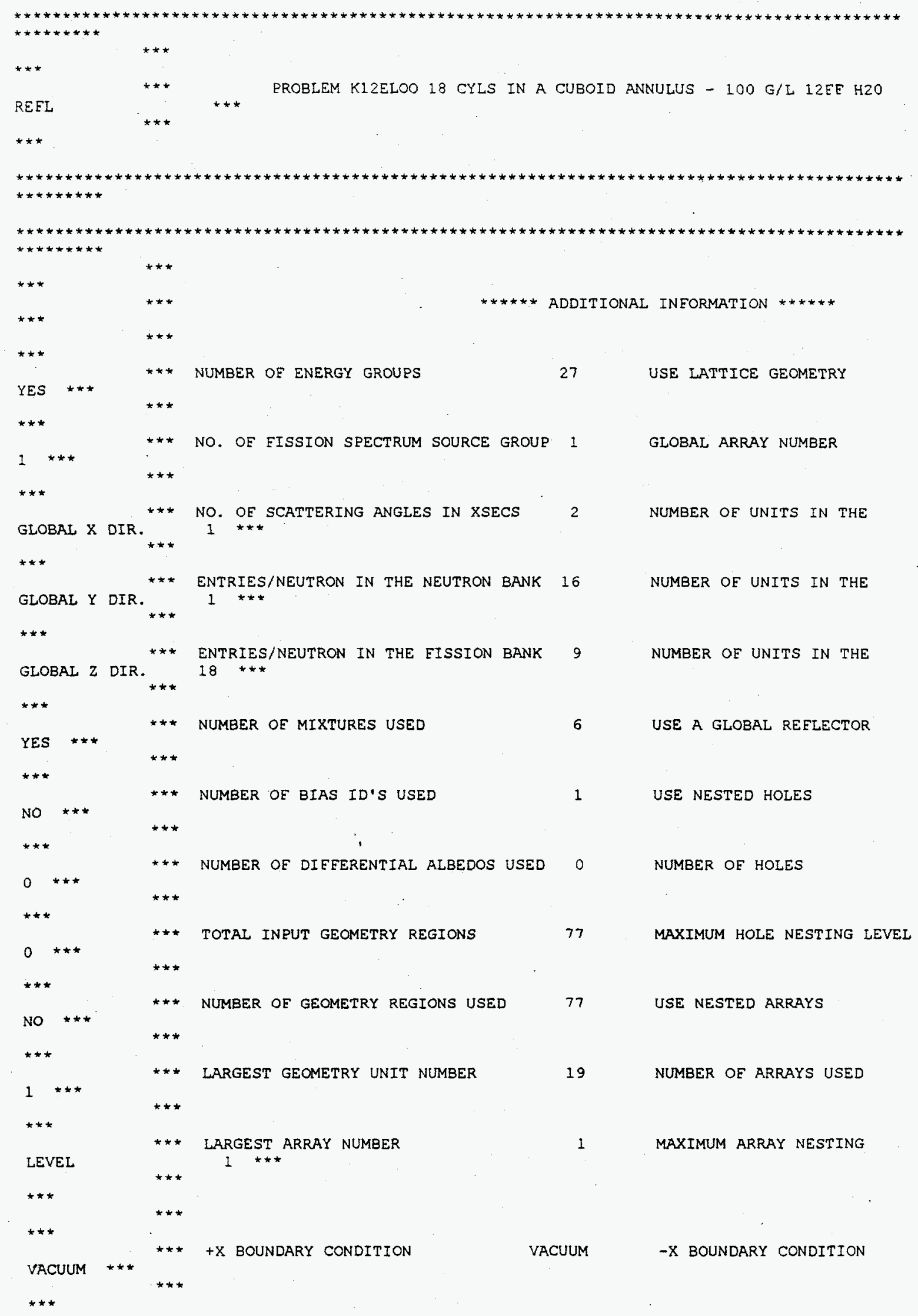




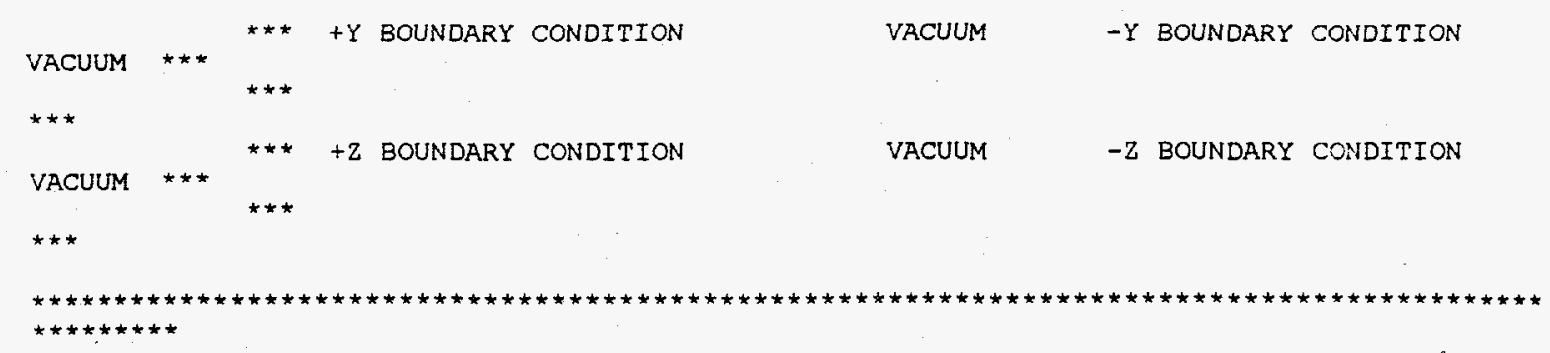




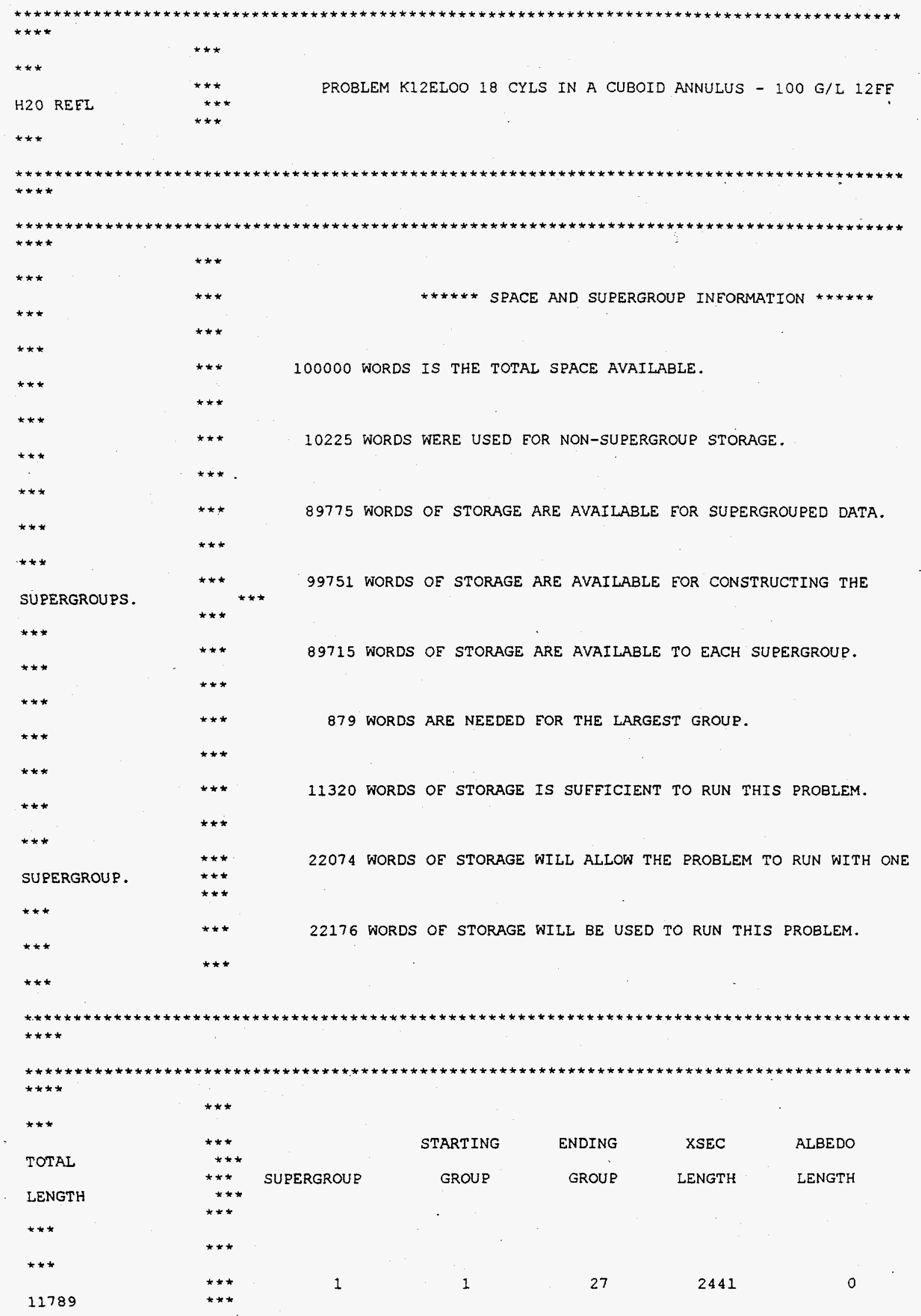


$* * *$

$* * *$

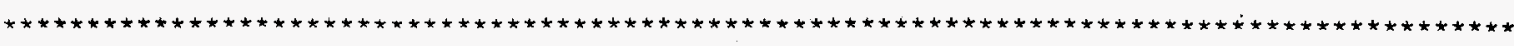
$\star \star \star \star \star$

O IO'S WERE USED IN SUPERGROUPING

$\ldots \ldots \ldots$

$\cdots$

O IO'S WERE USED LOADING THE DATA 
G/L 12EF H2O REEL

PROBLEM K12ELOO 18 CYLS IN A CUBOID ANNULUS - 100

MEDIA BIAS GEOMETRY DESCRIPTION EOR THOSE UNITS UTILIZED IN THIS
RROBLEM NEGION
NUM ID

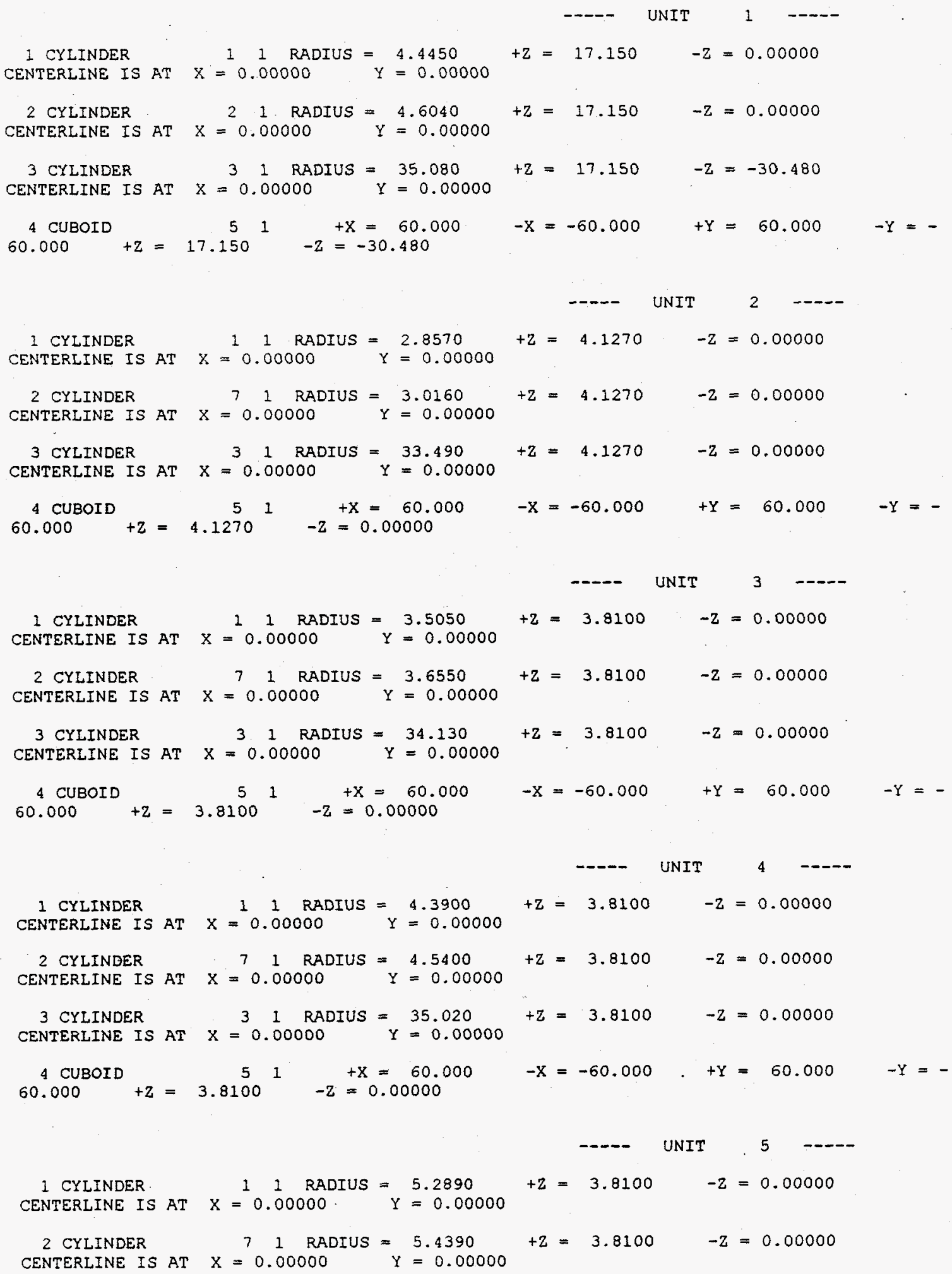




\section{F-54}

3 CYLINDER

31 RADIUS $=35.910$

$+z=3.8100$

$-z=0.00000$

CENTERLINE IS AT $\mathrm{X}=0.00000$ $Y=0.00000$

4 CUBOID $51+x=60.000$ 60.000 $+z=3.8100 \quad-z=0.00000$

$-\mathrm{X}=-60.000$

$+Y=60.000$ $-Y=-$ 
G/L 12FE H2O REFL

PROBLEM K12ELOO 18 CYLS IN A CUBOID ANNULUS - 100

MEDIA BIAS GEOMETRY DESCRIPTION FOR THOSE UNITS UTILIZED IN THIS
REGION
NUM ID

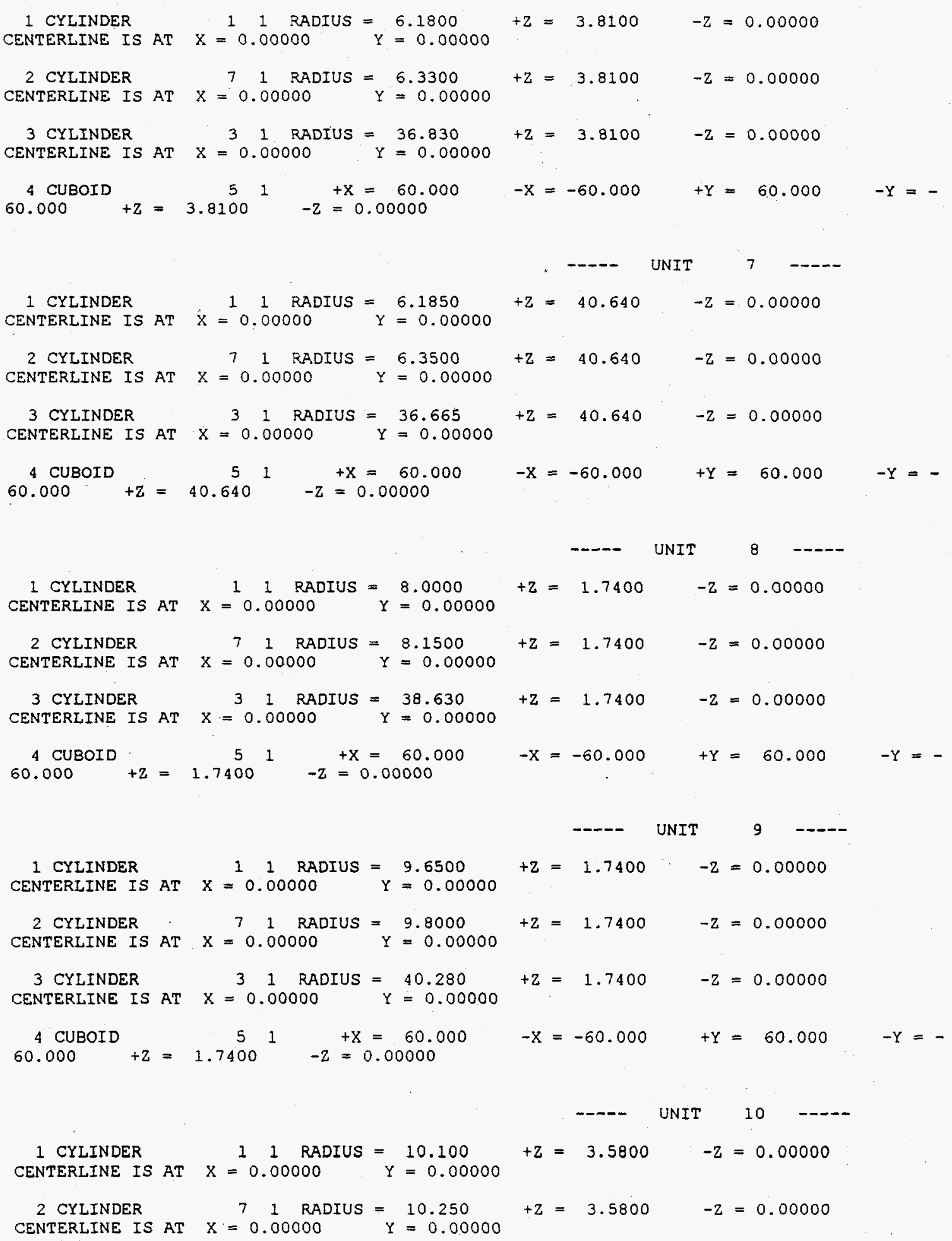




\section{F-56}

3 CYLINDER .

31 RADIUS $=40.730$

$+z=3.5800$

$-z=0.00000$ CENTERLINE IS AT $\mathrm{X}=0.00000$ $Y=0.00000$

4 CUBOID $51+\mathrm{X}=60.000$ 60.000 $+z=3.5800 \quad-z=0.00000$

$-\mathrm{x}=-60.000$

$+Y=60.000$

$-Y=-$ 
G/L 12EE H2O REEL

PROBLEM K12ELOO 18 CYLS IN A CUBOID ANNULUS - 100 $\begin{array}{ll}\text { PROBLEM } & \text { MEDIA BIAS GEOMETRY DESCRIPTION FOR THOSE UNITS UTILIZED IN THIS } \\ \text { REGION } & \text { NUM ID }\end{array}$

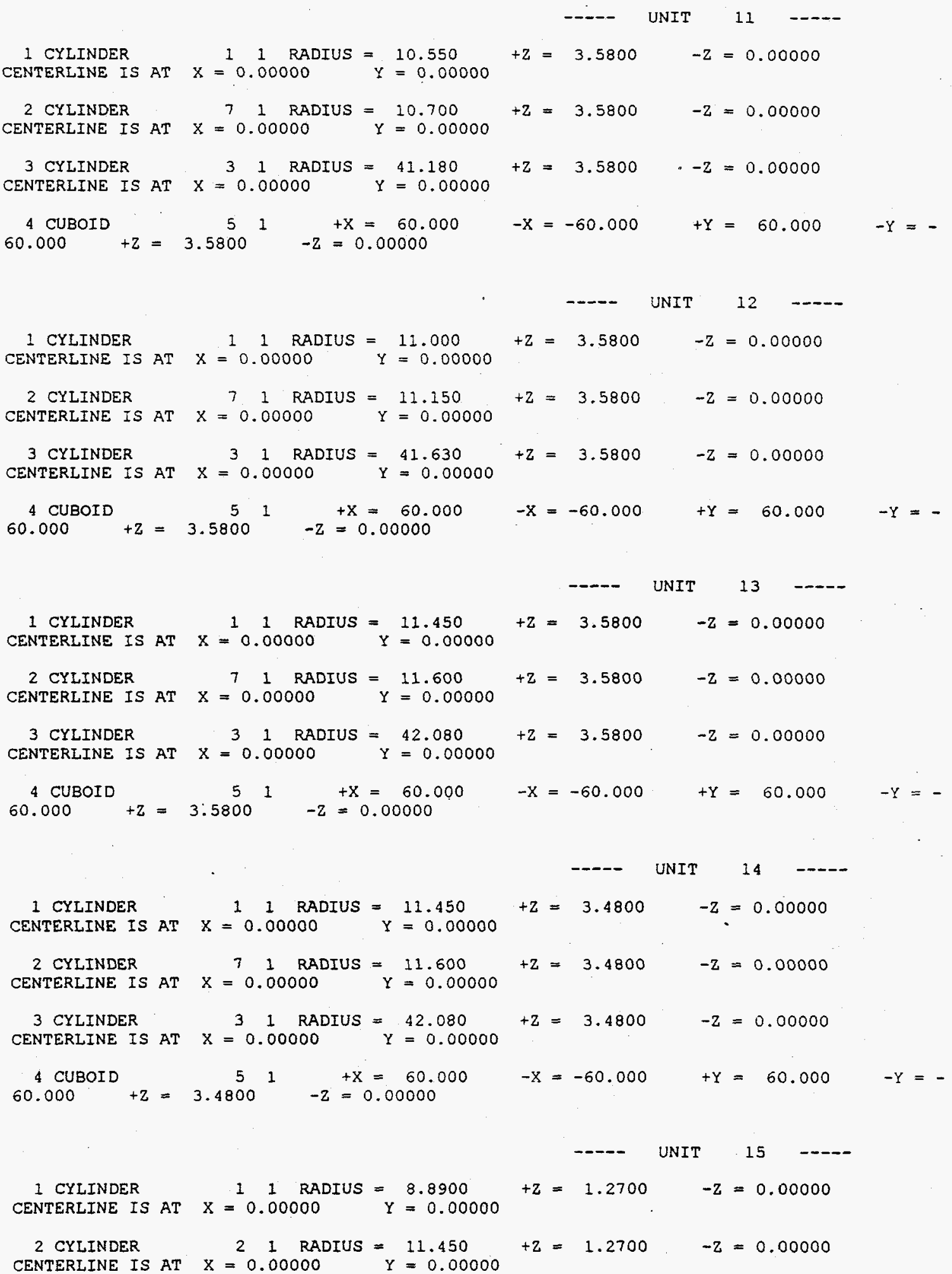




\section{F-58}

3 CYLINDER

31 RADIUS $=42.080$

$+z=1.2700$

$-z=0.00000$

CENTERLINE IS AT $\mathrm{X}=0.00000$ $Y=0.00000$

4 CUBOID

$\begin{array}{ccc}5 & 1 & +x=60.000 \\ +z=1.2700 & -z=0.00000\end{array}$

$-x=-60.000$

$+Y=60.000 \quad-Y=-$

60.000 
G/L 12FE H2O REFL

PROBLEM K12ELOO 18 CYLS IN A CUBOID ANNULUS - 100

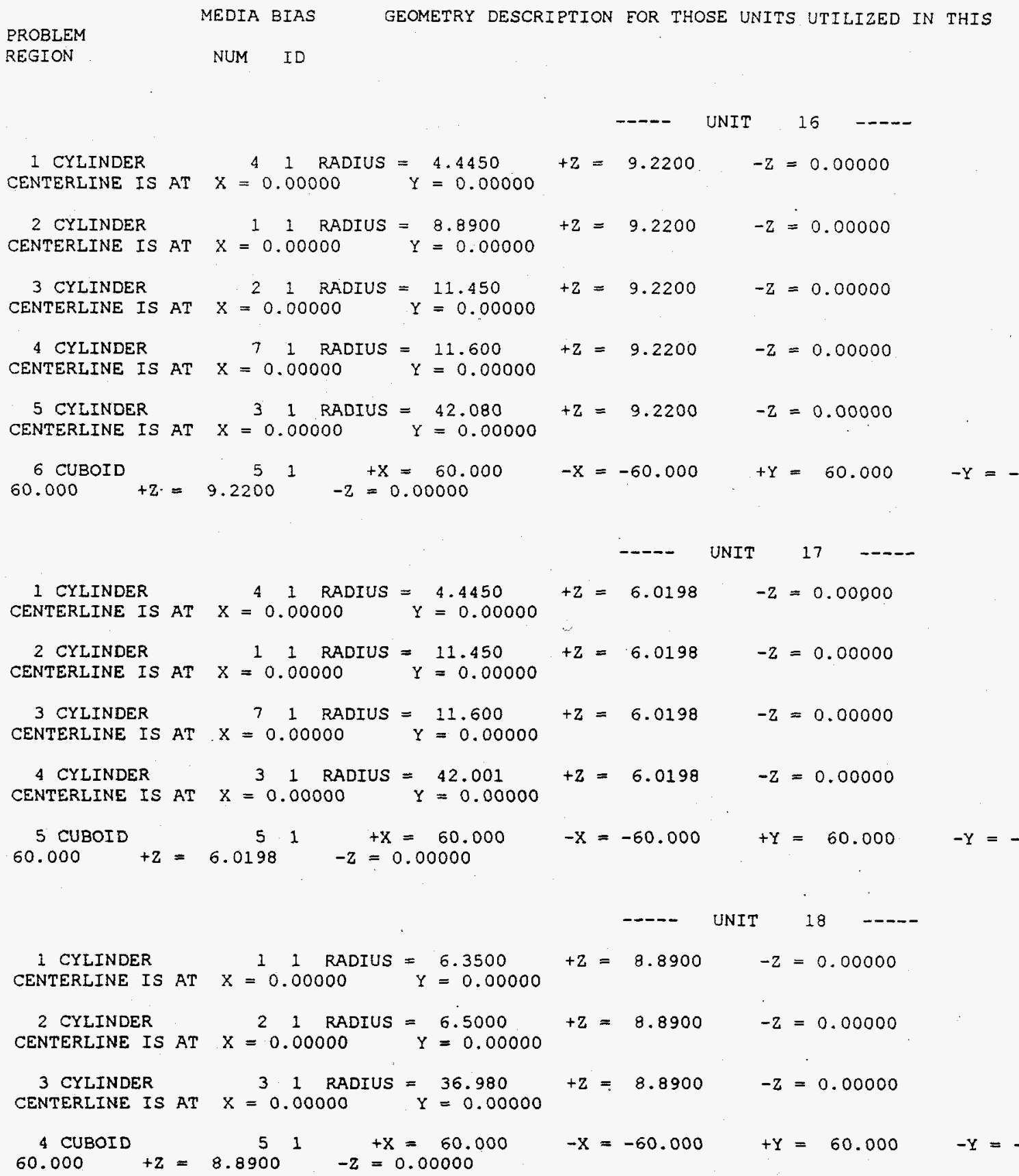

GLOBAL

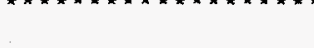

UNIT 19 EXTERNAL TO LATTICE

IDEFINES OVERALL COORDINATE SYSTEM

$\begin{array}{lccccc}1 \text { ARRAY NUMBER } & 1 & +X=120.00 & -X=0.00000 & +Y=120.00 & -Y= \\ 0.00000 & +Z=154.32 & -Z=0.00000 & & \\ .2 \text { CUBOID } & 51 & +X=120.00 & -X=0.00000 & +Y=120.00 & -Y= \\ 0.00000 & +Z=190.00 & -Z=0.00000 & & \end{array}$


REFL

PROBLEM K12ELOO 18 CYLS IN A CUBOID ANNULUS - $100 \mathrm{G} / \mathrm{L}$ 12EE H2O

UNIT ORIENTATION DESCRIPTION FOR ARRAY 1

2 LAYER $1, X$ COLUMN 1 TO 1 LEFT TO RIGHT Y ROW 1 TO 1 BOTTOM TO TOP

$\begin{array}{llllll}1 & \text { LAYER } & 2, X \text { COLUMN } 1 \text { TO } 1 \text { LEFT TO RIGHT Y ROW } 1 \text { TO } 1 \text { BOTTOM TO TOP }\end{array}$

2 .

Z LAYER 3, X COLUMN 1 TO 1 LEET TO RIGHT Y ROW 1 TO 1 BOTTOM TO TOP

2 LAYER $4, X$ COLUMN 1 TO 1 LEFT TO RIGHT Y RON 1 TO 1 BOTTOM TO TOP

2 LAYER 5, X COLUMN 1 TO 1 LEET TO RIGHT $Y$ ROW 1 TO 1 BOTTOM TO TOP

5
LAYER $6, X$ COLUMN 1 TO 1 LEET TO RIGHT Y ROW 1 TO 1 BOTTOM TO TOP

6
LAYER $7, x$ COLUMN 1 TO 1 LEET TO RIGHT Y ROW 1 TO 1 BOTTOM TO TOP

7

Z LAYER 8, X COLUMN I TO I LEET TO RIGHT Y ROW 1 TO 1 BOTTOM TO TOP

8

Z LAYER 9, X COLUMN 1 TO 1 LEFT TO RIGHT Y ROW 1 TO 1 BOTTOM TO TOR

9 TAER $10, \times$ COLUMN 1 TO 1 LEET TO RIGHT Y ROW 1 TO 1 BOTTOM TO TOP 
REEL

PROBLEM K12ELOO 18 CYLS IN A CUBOID ANNULUS - $100 \mathrm{G} / \mathrm{L} 12 \mathrm{EF}$ H2O

UNIT ORIENTATION DESCRIPTION EOR ARRAY 1 (CONT.)

Z LAYER 11, X COLUMN 1 TO 1 LEET TO RIGHT Y ROW 1 TO 1 BOTTOM TO TOP

2 LAYER 12, X COLUMN 1 TO 1 LEET TO RIGHT Y ROW 1 TO 1 BOTTOM TO TOP

12

Z LAYER 13, X COLUMN 1 TO 1 LEET TO RIGHT Y ROW 1 TO 1 BOTTOM TO TOP

13

2 LAYER 14, X COLUMN 1 TO 1 LEET TO RIGHT Y RON 1 TO 1 BOTTOM TO TOP

14

Z LAYER 15, X COLUMN 1 TO 1 LEET TO RIGHT Y ROW 1 TO 1 BOTTOM TO TOP

15

2 LAYER 16, X COLUMN 1 TO 1 LEET TO RIGHT Y ROW 1 IO 1 BOTTOM TO TOP

16

2 LAYER 17, X COLUMN 1 TO 1 LEET TO RIGHT Y ROW 1 TO 1 BOTTOM TO TOP

17

2 LAYER 18, X COLUMN 1 TO 1 LEET TO RIGHT Y ROW 1 TO 1 BOTTOM TO TOP 
G/L 12EE H2O REEL

CUMULATIVE

VOLUME

$1.06453 \mathrm{E}+03 \mathrm{CM}^{\star \star} 3$

$1.14205 \mathrm{E}+03 \mathrm{CM} * * 3$

$1.84141 \mathrm{E}+05 \mathrm{CM}^{* * 3}$

$6.85872 \mathrm{E}+05 \mathrm{CM} \star * 3$

1.05829E+02 CM**3

$1.27936 E+02 C M * * 3$

1. $45417 \mathrm{E}+\mathrm{O} 4 \mathrm{CM}^{\star *} 3$

$5.94288 \mathrm{E}+04 \mathrm{CM} * 3$

$1.47045 \mathrm{E}+02 \mathrm{CM} * * 3$

$1.59900 \mathrm{E}+02 \mathrm{CM} * * 3$

$1.39427 \mathrm{E}+04 \mathrm{CM} * 3$

5. $48640 \mathrm{E}+04 \mathrm{CM} * * 3$

$2.30677 \mathrm{E}+02 \quad \mathrm{CM} * * 3$

$2.46710 \mathrm{E}+02 \mathrm{CM}^{\star *} 3$

$1.46794 \mathrm{E}+04 \mathrm{CM} * * 3$

$5.48640 E+04 \quad C M * * 3$

3. 34828E+02 CM**3

$3.54089 \mathrm{E}+02 \quad \mathrm{CM} * 3$

1. $54350 \mathrm{E}+04 \mathrm{CM} * 3$

$5.48640 E+04 \quad C M * * 3$

4. $57143 E+02 C M * * 3$

$4.79603 \mathrm{E}+02 \quad C M * * 3$

$1.62360 \mathrm{E}+04 \mathrm{CM} * 3$

$5.48640 \mathrm{E}+04 \quad \mathrm{CM}^{* *} 3$

$4.88408 \mathrm{E}+03 \mathrm{CM} * * 3$

$5.14815 \mathrm{E}+03 \mathrm{CM} * \star 3$

1. $71635 \mathrm{E}+05 \mathrm{CM} * * 3$

$5.85216 \mathrm{E}+05 \mathrm{CM}^{* * 3}$

3. $49848 E+02 \quad \mathrm{CM}^{\star *} 3$ $3.63090 \mathrm{E}+02 \mathrm{CM} * * 3$
PROBLEM K12ELOO 18 CYLS IN A CUBOID ANNULUS - 100 VOLUMES EOR THOSE UNITS UTIIIZED IN THIS PROBLEM GEOMETRY

UNIT REGION REGION VOLUME

2

$$
\begin{aligned}
& 1.06453 \mathrm{E}+03 \mathrm{CM} * 3 \\
& 7.75197 \mathrm{E}+01 \mathrm{CM}^{* * 3} \\
& 1.82999 \mathrm{E}+05 \mathrm{CM} * * 3 \\
& 5.01731 \mathrm{E}+05 \mathrm{CM}^{* * 3}
\end{aligned}
$$

$1.05829 E+02 C M * * 3$

$1.21071 \mathrm{E}+01 . \mathrm{CM} * * 3$

$1.44237 \mathrm{E}+04 \quad \mathrm{CM} * * 3$

$4.48871 \mathrm{E}+04 \mathrm{CM} * 3$

3

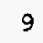

$1.47045 \mathrm{E}+02 \mathrm{CM}^{\star} \star 3$

$1.28552 \mathrm{E}+01 \mathrm{CM} * 3$

$1.37828 E+04 \mathrm{CM}^{* *} 3$

$4.09213 E+04 \quad C M^{* \star} 3$

$2.30677 E+02 C M * * 3$

$1.60331 \mathrm{E}+01 \mathrm{CM} * * 3$

$1.44327 \mathrm{E}+04 \mathrm{CM}^{*} * 3$

$4.01846 \mathrm{E}+04 \mathrm{CM} * * 3$

$3.34828 \mathrm{E}+02 \mathrm{CM} * 3$

$1.92613 \mathrm{E}+01 \mathrm{CM} * * 3$

$1.50809 \mathrm{E}+04 \quad \mathrm{CM}^{* *} 3$

3. $94290 E+04 C M * * 3$

$4.57143 E+02 \quad \mathrm{CM}^{* * 3}$

$2.24607 \mathrm{E}+01 \mathrm{CM} * 3$

$1.57564 \mathrm{E}+04 \mathrm{CM}^{2} * 3$

$3.86280 \mathrm{E}+04 \mathrm{CM} * * 3$

$4.88408 \mathrm{E}+03 \mathrm{CM} * 3$

$2.64065 E+02 \quad \mathrm{CM}^{*} * 3$

$1.66487 \mathrm{E}+05 \mathrm{CM}^{* * 3}$

$4.13581 \mathrm{E}+05 \mathrm{CM} * * 3$

8

1

29

$3.49848 \mathrm{E}+02 \mathrm{CM} * * 3$

1.32422E+01 CM**3 


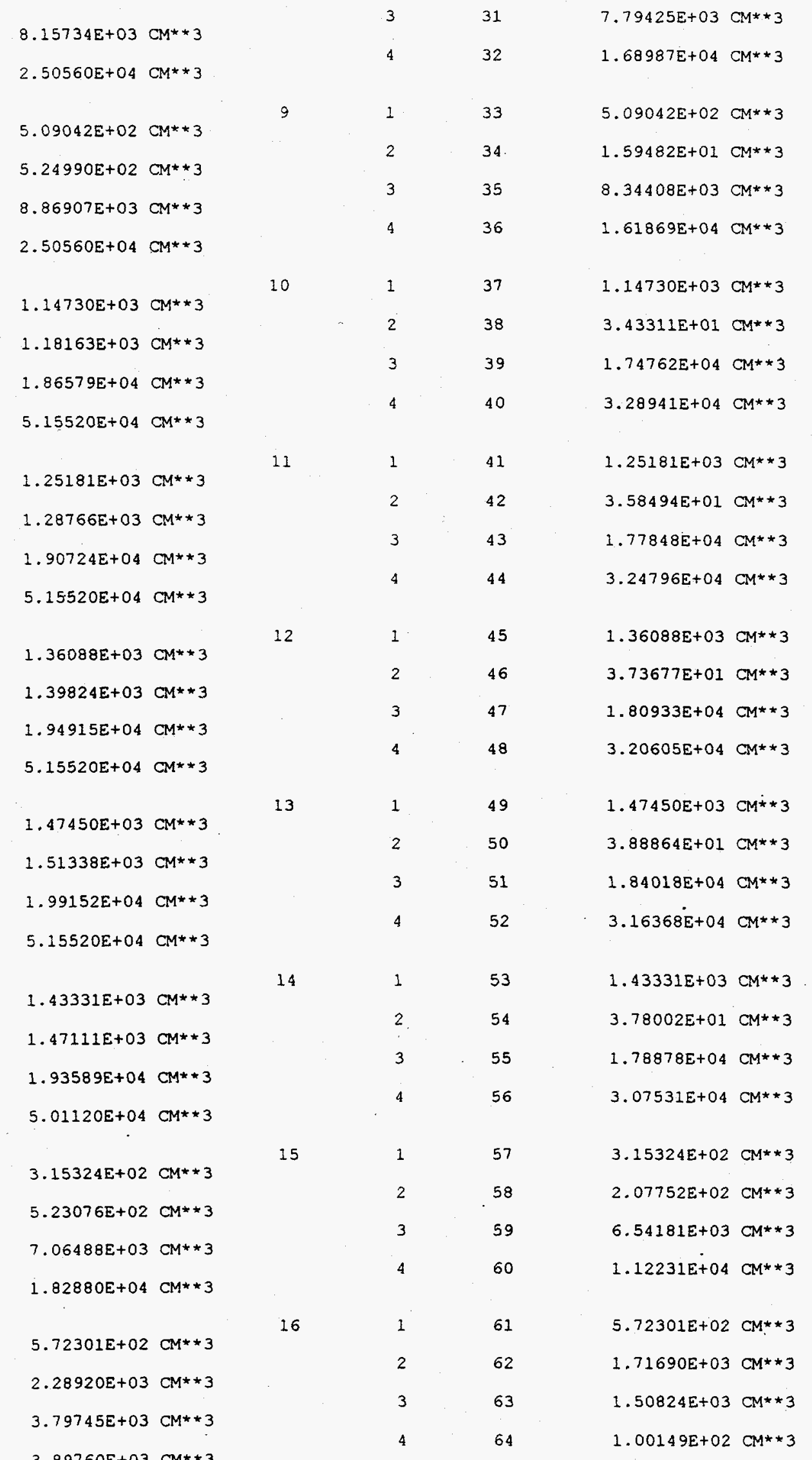




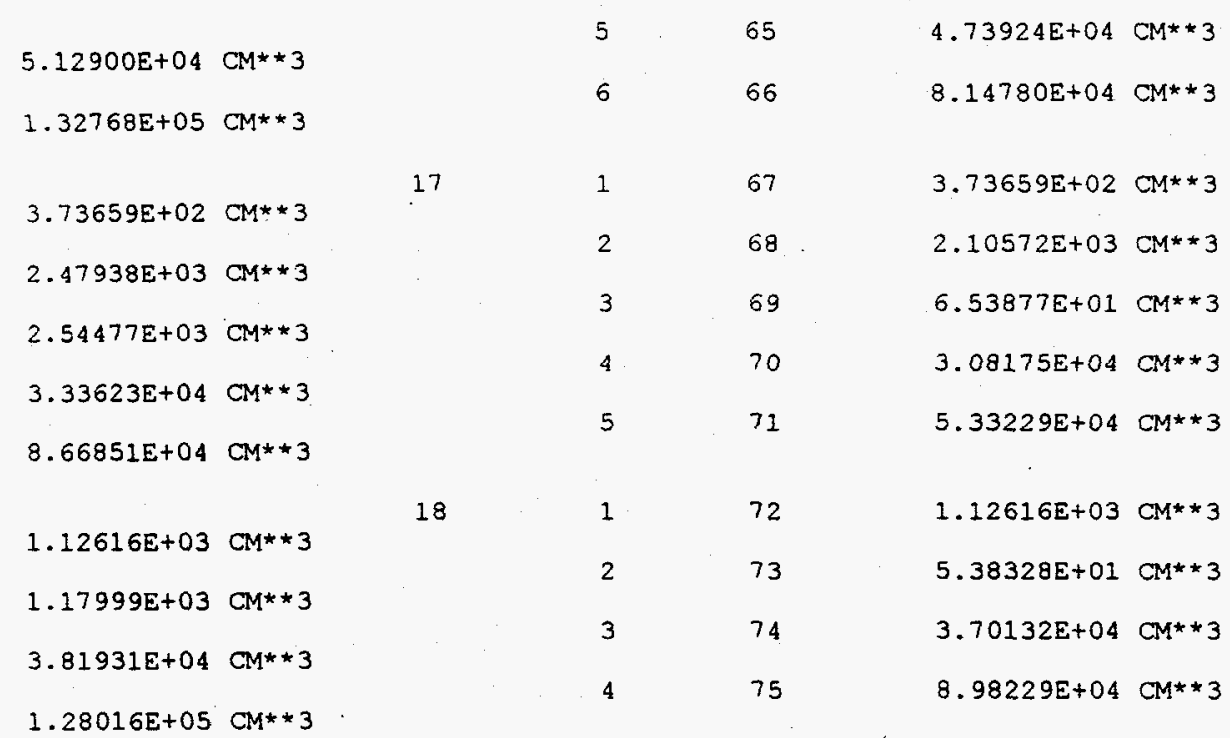

SURROUNDING GEOMETRY VOLUMES - GEOMETRY REGION 76 IS AN ARRAY PLACEMENT BOUNDARY REGION

$2.22216 \mathrm{E}+06 \mathrm{CM} * * 3$

$2.73600 \mathrm{E}+06 \mathrm{CM}^{\star * 3}$

VOLUME

$1.06453 \mathrm{E}+03 \mathrm{CM} * 3$

$7.75197 E+01 \quad \mathrm{CM}^{* * 3}$

1.82999E+05 CM**3

$5.01731 E+05 \mathrm{CM} * 3$

$1.05829 \mathrm{E}+02 \mathrm{CM} * * 3$

$1.21071 \mathrm{E}+01 \mathrm{CM} * * 3$

$1.44237 \mathrm{E}+04 \mathrm{CM}^{\star *} 3$

4. $48871 \mathrm{E}+04 \mathrm{CM}^{\star \star 3}$

$1.47045 \mathrm{E}+02 \mathrm{CM}^{* * 3}$

1. $28552 \mathrm{E}+0.1 \mathrm{CM} * * 3$

$1.37828 \mathrm{E}+04 \mathrm{CM}^{*} * 3$

$4.09213 \mathrm{E}+04 \mathrm{CM}^{* * 3}$

$2.30677 E+02 C M * * 3$

$1.60331 \mathrm{E}+01 \mathrm{CM} * * 3$

1. $44327 \mathrm{E}+04 \mathrm{CM}^{*} * 3$

$4.01846 \mathrm{E}+04 \mathrm{CM}^{* * 3}$

3. $34828 \mathrm{E}+02 \mathrm{CM} * * 3$
19

1

2

76

77

$2.22216 \mathrm{E}+06 \mathrm{CM} * * 3$

$5.13838 \mathrm{E}+05 \mathrm{CM}^{* * 3}$

UNIT USES REGION MIXTURE TOTAL

2

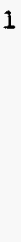

1

$\begin{array}{ll}1 & 1 \\ 2 & 2 \\ 3 & 3 \\ 4 & 5\end{array}$

1

$\begin{array}{ll}1 & 1 \\ 2 & 7 \\ 3 & 3 \\ 4 & 5\end{array}$

3

11

27

$3 \quad 3$

45

4

1

$\begin{array}{ll}1 & 1 \\ 2 & 7 \\ 3 & 3 \\ 4 & 5\end{array}$

5

1

1

1 
$1.92613 E+01 \quad C H * * 3$

$1.50809 E+04 \quad C_{K} * * 3$

$3.94290 E+04 \quad C M * * 3$

4. $57143 \mathrm{E}+02 \quad \mathrm{Cl} * * 3$

$2.24607 E+01 C M * * 3$

$1.57564 \mathrm{E}+04 C M * * 3$

$3.86280 E+04 \quad C M * * 3$

$4.88408 E+03 C M * * 3$

$2.64065 E+02 C M * * 3$

1. $66487 \mathrm{E}+05 \quad \mathrm{CM} * * 3$

$4.13581 \mathrm{E}+05 \mathrm{CM} * \star 3$

$3.49848 E+02 C M * * 3$

1. $32422 E+01 C M * * 3$

$7.79425 \mathrm{E}+03 \mathrm{CM} * 3$

1. $68987 \mathrm{E}+04 \mathrm{CM} * \star 3$

$5.09042 \mathrm{E}+02 \quad \mathrm{CM} * \star 3$

$1.59482 \mathrm{E}+01 \mathrm{CM} * * 3$

$8.34408 E+03 \quad \mathrm{CM}^{* *}+3$

1. $61869 \mathrm{E}+04 \mathrm{CM} * * 3$

1.14730E $+03 \quad \mathrm{CM} * * 3$

$3.43311 \mathrm{E}+01 \quad \mathrm{CM} * * 3$

$1.74762 \mathrm{E}+04 \mathrm{CM} * * 3$

$3.28941 E+04 C M * \star 3$

1. $25181 \mathrm{E}+03 \mathrm{CM} * \star 3$

$3.58494 \mathrm{E}+01 \mathrm{CM} * 3$

$1.77848 \mathrm{E}+04 \mathrm{CM} * * 3$

$3.24796 \mathrm{E}+04 \mathrm{CM} * * 3$

I. $36088 \mathrm{E}+03 \mathrm{CM} * * 3$

$3.73677 \mathrm{E}+01 \mathrm{CM} * 3$

$1.80933 \mathrm{E}+04 \quad \mathrm{CM} * * 3$

3. $20605 \mathrm{E}+04 \quad \mathrm{CM} * 3$

$1.47450 \mathrm{E}+03 \mathrm{CM} * * 3$

$3.88864 \mathrm{E}+01 \quad \mathrm{CM} * * 3$

$1.84018 \mathrm{E}+04 \mathrm{CM} * * 3$

6

7

11

2

3

9

3

1

2

3

10

$\begin{array}{ll}1 & 1 \\ 2 & 7 \\ 3 & 3 \\ 4 & 5\end{array}$

11

1

27

3

45

12

$\begin{array}{ll}1 & 1 \\ 2 & 7 \\ 3 & 3 \\ 4 & 5\end{array}$

13

$\begin{array}{ll}1 & 1 \\ 2 & 7 \\ 3 & 3\end{array}$


$3.16368 \mathrm{E}+04 \mathrm{CM} * 3$

1. $43331 \mathrm{E}+03 \mathrm{CM} * * 3$

$3.78002 E+01 C^{*} * 3$

$1.78878 \mathrm{E}+04 \mathrm{CM} * * 3$

$3.07531 \mathrm{E}+04 \mathrm{CM} * * 3$

$3.15324 \mathrm{E}+02 \mathrm{CM}^{*+3}$

15

$2.07752 \mathrm{E}+02 \mathrm{CM}^{* * 3}$

$6.54181 \mathrm{E}+03 \mathrm{CM} * * 3$

$1.12231 \mathrm{E}+04 \mathrm{CM}^{*} * 3$

$5.72301 \mathrm{E}+02 \mathrm{CM} * * 3$

$1.71690 \mathrm{E}+03 \mathrm{CM} * 3$

$1.50824 \mathrm{E}+03 \mathrm{CM} * 3$

1. $00149 \mathrm{E}+02 \mathrm{CM} * 3$

$4.73924 \mathrm{E}+04 \mathrm{CM} * 3$

$8.14780 \mathrm{E}+04 \mathrm{CM}^{* * 3}$

$3.73659 \mathrm{E}+02 \mathrm{CM} * 3$

17

$2.10572 E+03 C M * * 3$

$6.53877 \mathrm{E}+01 \mathrm{CM} * * 3$

3. $08175 \mathrm{E}+04 \mathrm{CM} * * 3$

$5.33229 \mathrm{E}+04 \mathrm{CM} \star * 3$

1. $12616 \mathrm{E}+03 \mathrm{CM} * * 3$

$5.38328 \mathrm{E}+01 \mathrm{CM} * * 3$

$3.70132 E+04 \quad C M * * 3$

$8.98229 \mathrm{E}+04 \mathrm{CM} * * 3$

$2.22216 \mathrm{E}+06 \mathrm{CM} * \star 3$

$5.13838 \mathrm{E}+05 \mathrm{CM} * * 3$

16

27

33

45

1

2

2

1

$3 \cdot 3$

45

1

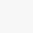




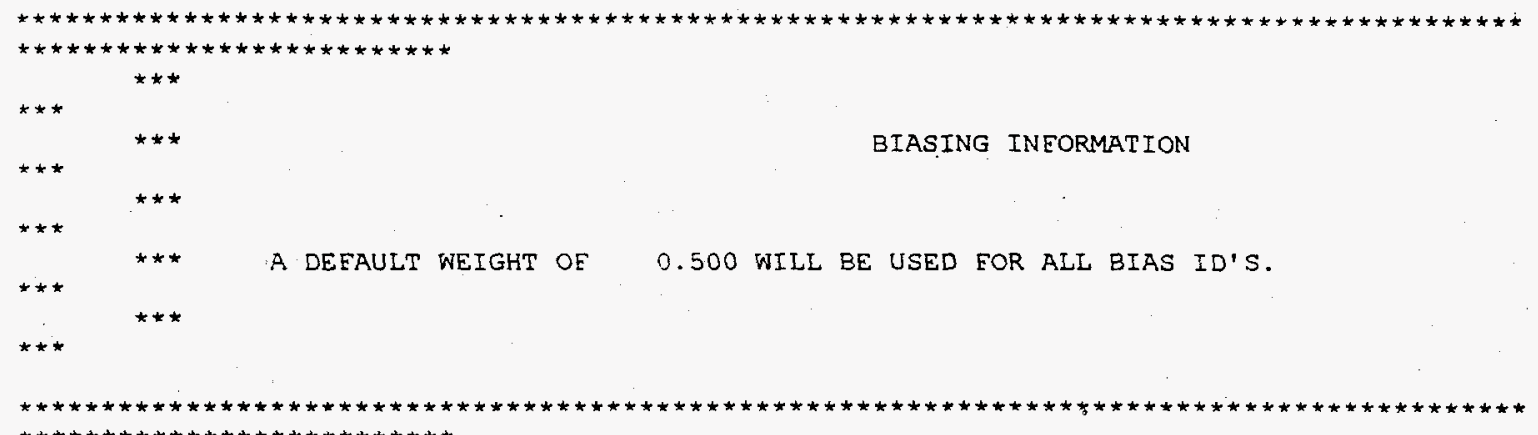

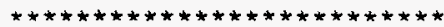

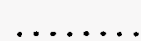

0 IO'S WERE USED IN KENO-V BEFORE TRACKING $\ldots \ldots$

0.22150 MINUTES WERE USED PROCESSING DATA.

VOLUME ERACTION OF EISSILE MATERIAL IN THE CORE $=9.43265 E-03$

START TYPE O WAS USED.

THE NEUTRONS WERE STARTED WITH A ELAT DISTRIBUTION IN A CUBOID DEEINED BY:

$+Z=1.54317 E+02 \quad-Z=0.0001 .20000 E+02 \quad-X=0.00000 E+00 \quad+Y=1.20000 E+02 \quad-Y=0.00000 E+00$ THE FLAG TO START NEUTRONS IN THE REELECTOR WAS TURNED OFF

0.09450 MINUTES WERE REQUIRED FOR STARTING. TOTAL ELARSED TIME IS 0.32000 MINUTES. 
PROBLEM K12ELOO 18 CYLS IN A CUBOID ANNULUS - 100 G/L 12 EF H2O REFL

\begin{tabular}{|c|c|c|c|c|}
\hline MATRIX & $\begin{array}{l}\text { GENERATION } \\
\text { MATRIX K-EFE }\end{array}$ & ELAESED TIME & AVERAGE & AVG K-EEE \\
\hline GENERATION & N K-EFEECTIVE & MINUTES & K-EEFECTIVE & DEVIATION \\
\hline EEEECTIVE & DEVIATION & & & \\
\hline $\begin{array}{l}\text { KENO MESSAGE N } \\
\text { GENERATED }\end{array}$ & NUMBER K5-132 & WARNING.... ONLY & 299 INDERENDENT & EISSION POINTS WERE \\
\hline $0.00000 \mathrm{E}+00$ & $\begin{array}{l}8.40679 E-01 \\
0.00000 E+00\end{array}$ & $3.64333 E-01$ & $1.00000 \mathrm{E}+00$ & $0.00000 E+00$ \\
\hline
\end{tabular}

WARNING... ONLY 270 INDEPENDENT EISSION POINTS WERE

KENO MESSAGE NUMBER K5-132

GENERATED

$27.69348 \mathrm{E}-01$

4. $11833 \mathrm{E}-01$

$1.00000 \mathrm{E}+00$

$0.00000 \mathrm{E}+00$

$4.54000 \mathrm{E}-01$

$8.81244 E-01$

$0.00000 E+00$

$0.00000 E+00$

$8.81244 \mathrm{E}-01$

$0.00000 E+00$

9.42993E-01

$0.00000 E+00$

$0.00000 E+00$

$8.92263 E-01$

$0.00000 E+00$

$0.00000 E+00$

$8.63004 \mathrm{E}-01$

$0.00000 \mathrm{E}+00$

$9.02710 \mathrm{E}-01$

$0.00000 \mathrm{E}+00$

1. $03145 \mathrm{E}+00$

$0.00000 \mathrm{E}+00$

$9.58121 \mathrm{E}-01$

$0.00000 E+00$

$9.36590 \mathrm{E}-01$

$0.00000 E+00$

$9.63494 \mathrm{E}-01$

$0.00000 \mathrm{E}+00$

$9.56961 \mathrm{E}-01$

$0.00000 \mathrm{E}+00$

$9.14207 \mathrm{E}-01$

$0.00000 E+00$

$9.51945 \mathrm{E}-01$

$0.00000 E+00$

$9.76000 \mathrm{E}-01$

$0.00000 E+00$

$8.00616 \mathrm{E}-01$

$0.00000 E+00$

4. $93333 E-01$

9.12118E-01

$3.08746 E-02$

$5.39167 E-01$

9.05500E-01

1. $90145 E-02$

$5.84000 E-01$

8. $94876 E-01$

1.71361E-02

$6.28833 \mathrm{E}-01$

$8.96443 \mathrm{E}-01$

1. $33657 \mathrm{E}-02$

$6.71833 E-01$

$9.18944 \mathrm{E}-01$

2.50080E-02

$7.16667 E-01$

$9.24540 E-01$

$2.18640 \mathrm{E}-02$

$7.58833 \mathrm{E}-01$

9.26047E-01

$1.89946 E-02$

8.00000E-01

9.30207E-01

1. 72607 E-02

8.44833E-01

9.32883E-01

1. $56685 E-02$

8. 89833E-01

9. 31185E-01

1. $42740 E-02$

9. $35500 E-01$

9.32915E-01

1. $31447 \mathrm{E}-02$

$9.79500 E-01$

$9.36229 E-01$

1. $25374 \mathrm{E}-02$

$1.02883 \mathrm{E}+00$

$9.26543 \mathrm{E}-01$

1.51183E-02

$1.07567 E+00$

$9.22030 \mathrm{E}-01$

1. $47802 E-02$

$1.11400 E+00$

$9.26422 E-01$

1. $45064 \mathrm{E}-02$

$1.15433 E+00$

9.26195E-01

1. 36283E-02

1.20100E+00

9. 22503E-01

1. 33689E-02

$1.24683 E+00$

9. 25190E-O1

1.29280E-02

1. $28700 \mathrm{E}+00$

9. $28041 E-01$

1.25917E-02

1. $33367 \mathrm{E}+00$

9.26959E-01

1. 20260E-02

$1.37400 \mathrm{E}+00$

$9.30719 E-01$

1.20673E-02

$1.42433 E+00$

$9.29566 \mathrm{E}-01$

$1.15882 E-02$

$1.46650 \mathrm{E}+00$

9. $30367 E-01$

$1.11237 \mathrm{E}-02$

1. $51500 E+00$

$9.26386 \mathrm{E}-01$

1. $13878 \mathrm{E}-02$

$1.55900 E+00$

9. $26158 \mathrm{E}-01$

$1.09434 E-02$

$1.60283 \mathrm{E}+00$

$9.27927 E-01$

1. $06779 \mathrm{E}-02$

$9.73936 \mathrm{E}-01$

$0.00000 E+00$

$9.09946 \mathrm{E}-01$

$0.00000 E+00$

$9.16268 \mathrm{E}-01$

$0.00000 \mathrm{E}+00$

$9.49573 E-01$

$0.00000 \mathrm{E}+00$

$9.78290 E-01$

$1.64583 E+00$

$9.27285 \mathrm{E}-01$

$1.03095 E-02$

$1.68900 \Sigma+00$

9. 26905E-01

$9.95494 \mathrm{E}-03$

$1.73567 \mathrm{E}+00$

9.27661E-01

$9.64702 \mathrm{E}-03$

1. $78050 E+00$

9.29294E-01

$9.47249 \mathrm{E}-03$ 


\begin{tabular}{|c|c|c|c|c|}
\hline $\begin{array}{c}34 \\
0.00000 E+00\end{array}$ & $\begin{array}{l}9.61561 E-01 \\
0.00000 E+00\end{array}$ & $1.82617 \Xi+00$ & $9.30302 \mathrm{E}-01$ & $9.22696 E-0.3$ \\
\hline 35 & $9.43113 E-01$ & $1.87383 \mathrm{E}+00$ & $9.30690 \mathrm{E}-01$ & $8.95141 \mathrm{E}-03$ \\
\hline $0.00000 \mathrm{E}+00$ & $0.00000 \mathrm{E}+00$ & & & \\
\hline 36 & $9.81764 \mathrm{E}-01$ & $1.91683 E+00$ & $9.32193 E-01$ & $8.81311 E-03$ \\
\hline $0.00000 \mathrm{E}+00$ & $0.00000 \mathrm{E}+00$ & & & \\
\hline 37 & $9.77347 \mathrm{E}-01$ & $1.95900 E+00$ & $9.33483 E-01$ & $8.65431 E-03$ \\
\hline $0.00000 E+00$ & $0.00000 E+00$ & & & \\
\hline 38 & $9.10226 \mathrm{E}-01$ & $2.00650 E+00$ & $9.32837 \mathrm{E}-01$ & $8.43525 \mathrm{E}-03$ \\
\hline $0.00000 \mathrm{E}+00$ & $0.00000 \mathrm{E}+00$ & & & \\
\hline 39 & $8.46691 \mathrm{E}-01$ & $2.05417 E+00$ & $9.30508 \mathrm{E}-01$ & $8.52807 \mathrm{E}-03$ \\
\hline $0.00000 E+00$ & $0.00000 E+00$ & & & \\
\hline .40 & $8.90012 E-01$ & $2.10083 E+00$ & $9.29443 E-01$ & $8.36875 E-03$ \\
\hline $0.00000 \mathrm{E}+00$ & $0.00000 E+00$ & & & \\
\hline 41 & $9.44349 E-01$ & $2.14483 E+00$ & $9.29825 \mathrm{E}-01$ & $8.16029 E-03$ \\
\hline $0.00000 E+00$ & $0.00000 E+00$ & & & \\
\hline 42 & $9.52331 E-01$ & $2.19050 \mathrm{E}+00$ & $9.30388 \mathrm{E}-01$ & $7.97355 \mathrm{E}-03$ \\
\hline $0.00000 \mathrm{E}+00$ & $0.00000 E+00$ & & & \\
\hline 43 & $9.12439 E-01$ & $2.23633 E+00$ & $9.29950 \mathrm{E}-01$ & $7.78895 E-03$ \\
\hline $0.00000 \mathrm{E}+00$ & $0.00000 E+00$ & & & \\
\hline 44 & $9.10956 \mathrm{E}-01$ & $2.28300 E+00$ & $9.29498 E-01$ & $7.61468 \mathrm{E}-03$ \\
\hline $0.00000 E+00$ & $0.00000 E+00$ & & & \\
\hline 45 & $9.24223 E-01$ & $2.32600 \mathrm{E}+00$ & $9.29375 \mathrm{E}-01$ & $7.43650 E-03$ \\
\hline $0.00000 E+00$ & $0.00000 \mathrm{E}+00$ & & & \\
\hline 46 & $9.84137 E-01$ & $2.36550 \mathrm{E}+00$ & $9.30620 E-01$ & $7.37135 \mathrm{E}-03$ \\
\hline $0.00000 E+00$ & $0.00000 E+00$ & & & \\
\hline 47 & $9.32272 \mathrm{E}-01$ & $2.41400 \mathrm{E}+00$ & $9.30656 E-01$ & $7.20577 \mathrm{E}-0.3$ \\
\hline $\begin{array}{r}0.00000 \mathrm{E}+00 \\
48\end{array}$ & $0.00000 E+00$ & & & \\
\hline $0.00000 E+00$ & $\begin{array}{l}9.07521 E-01 \\
0.00000 E+00\end{array}$ & $2.45183 E+00$ & $9.30153 E-01$ & $7.06531 \mathrm{E}-03$ \\
\hline 49 & $1.00720 E+00$ & $2.50267 \mathrm{E}+00$ & $9.31793 E-01$ & $7.10506 \mathrm{E}-03$ \\
\hline $0.00000 E+00$ & $0.00000 E+00$ & & & \\
\hline $\begin{array}{c}50 \\
0.000005+00\end{array}$ & $9.10082 E-01$ & $2.54483 E+00$ & $9.31340 E-01$ & $6.97015 E-03$ \\
\hline $\begin{array}{r}0.00000 \mathrm{E}+00 \\
51\end{array}$ & $\begin{array}{l}0.00000 E+00 \\
8.93321 E-01\end{array}$ & $2.58967 \mathrm{E}+00$ & $9.30564 E-01$ & $6.87037 E-03$ \\
\hline $0.00000 \mathrm{E}+00$ & $0.00000 E+00$ & & & $0.87031 \mathrm{E}-03$ \\
\hline 52 & $9.19406 \mathrm{E}-01$ & $2.63550 E+00$ & $9.30341 E-01$ & $6.73526 \mathrm{E}-03$ \\
\hline $\begin{array}{c}0.00000 \mathrm{E}+00 \\
53\end{array}$ & $0.00000 E+00$ & & & \\
\hline & $\begin{array}{l}9.01864 \mathrm{E}-01 \\
0.00000 \mathrm{E}+00\end{array}$ & $2.68300 \mathrm{E}+00$ & $9.29783 E-01$ & $6.62545 E-03$ \\
\hline $\begin{array}{c}0.00000 \mathrm{E}+00 \\
54\end{array}$ & & $2.73067 E+00$ & $9.28249 \mathrm{E}-01$ & \\
\hline $0.00000 E+00$ & $0.00000 E+00$ & & $9.202498-01$ & $6.67550 \mathrm{E}-03$ \\
\hline 55 & $9.80486 E-01$ & $2.77183 E+00$ & $9.29234 \mathrm{E}-01$ & $6.62209 \mathrm{E}-03$ \\
\hline $0.00000 E+00$ & $0.00000 E+00$ & & & \\
\hline 56 & $9.10251 E-01$ & $2.81483 E+00$ & $9.28883 \mathrm{E}-01$ & $6.50781 E-03$ \\
\hline $0.00000 E+00$ & $0.00000 E+00$ & & & \\
\hline 57 & $9.62094 \mathrm{E}-01$ & $2.85517 E+00$ & $9.29487 \mathrm{E}-01$ & $6.41686 \mathrm{E}-03$ \\
\hline $\begin{array}{c}0.00000 E+00 \\
58\end{array}$ & $0.00000 E+00$ & & & \\
\hline 58 & $9.50098 \mathrm{E}-01$ & $2.89817 \mathrm{E}+00$ & $9.29855 E-01$ & $6.31197 \mathrm{E}-03$ \\
\hline $0.00000 E+00$ & $0.00000 \mathrm{E}+00$ & & & \\
\hline $\begin{array}{c}59 \\
0.00000 E+00\end{array}$ & $\begin{array}{l}9.06746 E-01 \\
0.00000 E+00\end{array}$ & $2.94583 E+00$ & $9.29449 E-01$ & $6.21349 \mathrm{E}-03$ \\
\hline $\begin{array}{r}.00000 E+00 \\
60\end{array}$ & $9.57345 E-01$ & $2.98883 \mathrm{E}+00$ & $9.29930 \mathrm{E}-01$ & $6.12434 \mathrm{E}-03$ \\
\hline $0.00000 E+00$ & $0.00000 E+00$ & & & \\
\hline 61 & $9.56170 \mathrm{E}-01$ & $3.03367 E+00$ & $9.30375 E-01$ & $6.03604 \mathrm{E}-03$ \\
\hline $0.00000 E+00$ & $0.00000 E+00$ & & & \\
\hline 62 & $9.06277 \mathrm{E}-01$ & $3.07850 \mathrm{E}+00$ & $9.29973 E-01$ & $5.9481 ? \mathrm{E}-03$ \\
\hline $0.00000 E+00$ & $0.00000 \mathrm{E}+00$ & & & \\
\hline 63 & $9.03276 \mathrm{E}-01$ & 3. $12150 \mathrm{E}+00$ & $9.29536 \mathrm{E}-01$ & $5.86619 \mathrm{E}-03$ \\
\hline $\begin{array}{c}0.00000 \mathrm{E}+00 \\
64\end{array}$ & $\begin{array}{l}0.00000 E+00 \\
9.54427 E-01\end{array}$ & $3.16650 E+00$ & $9299375-01$ & $5784755-03$ \\
\hline $0.00000 E+00$ & $\begin{array}{l}9.54427 \mathrm{E}-01 \\
0.00000 \mathrm{E}+00\end{array}$ & & $9.299316-01$ & $5.18415 \mathrm{E}-03$ \\
\hline 65 & $9.58690 \mathrm{E}-01$ & $3.21133 E+00$ & $9.30393 \mathrm{E}-01$ & $5.71045 E-03$ \\
\hline $0.00000 E+00$ & $0.00000 E+00$ & & & \\
\hline 66 & $8.82497 E-01$ & $3.25517 \mathrm{E}+00$ & $9.29645 E-01$ & $5.67013 \mathrm{E}-03$ \\
\hline $0.00000 E+00$ & $0.00000 \mathrm{E}+00$ & & & \\
\hline 67 & $9.84573 \mathrm{E}-01$ & $3.30100 \mathrm{E}+00$ & $9.30490 E-01$ & $5.64581 E-03$ \\
\hline $00000 E+00$ & $0.00000 E+00$ & & & \\
\hline 68 & $9.11503 \mathrm{E}-01$ & $3.34317 E+00$ & $9.30202 E-01$ & $5.56705 E-03$ \\
\hline $0.00000 E+00$ & $0.00000 E+00$ & & & \\
\hline $\begin{array}{c}69 \\
0.00000 E+00\end{array}$ & $\begin{array}{l}9.66710 \mathrm{E}-01 \\
0.00000 \mathrm{E}+00\end{array}$ & $3.38617 \mathrm{E}+00$ & $9.30747 \mathrm{E}-01$ & $5.51034 \mathrm{E}-03$ \\
\hline 70 & $9.96421 E-01$ & $3.43183 E+00$ & $9.31713 \mathrm{E}-01$ & $5.51394 \mathrm{E}-03$ \\
\hline $0.00000 \mathrm{E}+00$ & $0.00000 E+00$ & & & \\
\hline 71 & $8.44103 E-01$ & $3.47767 E+00$ & $9.30443 E-01$ & $5.57982 E-03$ \\
\hline
\end{tabular}




\begin{tabular}{|c|c|c|c|c|}
\hline $\begin{array}{c}72 \\
0.00000 E+00\end{array}$ & $\begin{array}{l}9.72037 E-01 \\
0.00000 E+00\end{array}$ & $3.52067 \mathrm{E}+00$ & $9.31038 E-01$ & $5.53154 \mathrm{E}-03$ \\
\hline 73 & $8.54520 E-01$ & $3.56733 \mathrm{E}+00$ & $9.29960 \mathrm{E}-01$ & $5.55855 \mathrm{E}-03$ \\
\hline $0.00000 \mathrm{E}+00$ & $0.00000 \mathrm{E}+00$ & & & \\
\hline 74 & $9.53675 \mathrm{E}-01$ & $3.61683 E+00$ & $9.30289 \mathrm{E}-01$ & $5.49069 E-03$ \\
\hline $0.00000 E+00$ & $0.00000 E+00$ & & & \\
\hline 75 & $9.00844 \mathrm{E}-01$ & $3.66167 \mathrm{E}+00$ & $9.29886 E-01$ & $5.42996 \mathrm{E}-03$ \\
\hline $0.00000 E+00$ & $0.00000 E+00$ & & & \\
\hline 76 & $9.51456 E-01$ & $3.70567 E+00$ & $9.30177 \mathrm{E}-01$ & $5.36400 E-03$ \\
\hline $0.00000 E+00$ & $0.00000 E+00$ & & & \\
\hline 77 & $9.22897 \mathrm{E}-01$ & $3.75417 \mathrm{E}+00$ & $9.30080 E-01$ & $5.29289 \mathrm{E}-03$ \\
\hline $0.00000 E+00$ & $0.00000 E+00$ & & & \\
\hline 78 & $9.55999 \mathrm{E}-01$ & $3.79717 \mathrm{E}+00$ & $9.30421 E-01$ & $5.23390 \mathrm{E}-03$ \\
\hline $0.00000 E+00$ & $0.00000 E+00$ & & & \\
\hline $\begin{array}{c}79 \\
0.00000 \mathrm{E}+00\end{array}$ & $\begin{array}{l}9.55721 E-01 \\
0.00000 E+00\end{array}$ & $3.84300 E+00$ & $9.30750 E-01$ & $5.17592 \mathrm{E}-03$ \\
\hline 80 & $9.05932 E-01$ & $3.88500 E+00$ & $9.30432 E-01$ & $5.11903 E-03$ \\
\hline $0.00000 E+00$ & $0.00000 E+00$ & & & \\
\hline $0.00000 E+00$ & $\begin{array}{l}8.97176 E-01 \\
0.00000 E+00\end{array}$ & $3.93350 E+00$ & $9.30011 \mathrm{E}-01$ & $5.07132 \mathrm{E}-03$ \\
\hline $\begin{array}{c}82 \\
0.00000 E+00\end{array}$ & $\begin{array}{l}9.93124 E-01 \\
0.00000 E+00\end{array}$ & $3.97467 \mathrm{E}+00$ & $9.30800 E-01$ & $5.06929 E-03$ \\
\hline 83 & $9.03353 E-01$ & $4.01967 E+00$ & $9.30461 E-01$ & $5.01777 E-03$ \\
\hline $\begin{array}{c}0.00000 E+00 \\
84\end{array}$ & $0.00000 E+00$ & & & \\
\hline $0.00000 E+00$ & $\begin{array}{l}8.96965 E-01 \\
0.00000 E+00\end{array}$ & $4.06533 E+00$ & $9.30052 E-01$ & $4.97300 E-03$ \\
\hline $\begin{array}{r}0.00000 E+00 \\
85\end{array}$ & & & & \\
\hline $0.00000 \mathrm{E}+00$ & $\begin{array}{l}9.13055 E-01 \\
0.00000 E+00\end{array}$ & $4.10835 \mathrm{t}+00$ & $9.30578 \mathrm{E}-01$ & $4.94073 E-03$ \\
\hline $\begin{array}{c}86 \\
0.00000 E+00\end{array}$ & $\begin{array}{l}8.98091 E-01 \\
0.00000 E+00\end{array}$ & $4.15233 E+00$ & $9.30191 \mathrm{E}-01$ & $4.89685 E-03$ \\
\hline 87 & $8.98869 E-01$ & $4.19717 \mathrm{E}+00$ & $9.29822 \mathrm{E}-01$ & $4.85291 E-03$ \\
\hline $0.00000 E+00$ & $0.00000 E+00$ & & & \\
\hline $\begin{array}{c}88 \\
0\end{array}$ & 8.94481E-01 & $4.24300 E+00$ & $9.29412 \mathrm{E}-01$ & $4.81372 \mathrm{E}-03$ \\
\hline $\begin{array}{r}0.00000 E+00 \\
89\end{array}$ & $\begin{array}{l}0.00000 E+00 \\
9.61341 E-01\end{array}$ & $4.28867 E+00$ & $9.29779 E-01$ & \\
\hline $0.00000 \mathrm{E}+00$ & $0.00000 E+00$ & & & $4.77221 E-03$ \\
\hline $\begin{array}{c}90 \\
0.00000 \mathrm{E}+00\end{array}$ & $\begin{array}{l}9.61289 E-01 \\
0.00000 E+00\end{array}$ & $4.33000 \mathrm{E}+00$ & $9.30137 \mathrm{E}-01$ & $4.73123 E-03$ \\
\hline 91 & $9.37258 \mathrm{E}-01$ & $4.37567 \mathrm{E}+00$ & $9.30217 E-01$ & $4.67846 \mathrm{E}-03$ \\
\hline $\begin{array}{c}0.00000 E+00 \\
92\end{array}$ & $0.00000 E+00$ & & & \\
\hline $0.00000 E+00$ & $1.01139 \mathrm{E}+00$ & $4.41683 \mathrm{E}+00$ & $9.31119 \mathrm{E}-01$ & $4.71329 E-03$ \\
\hline $\begin{array}{r}93 \\
0.00000 E+00\end{array}$ & $\begin{array}{l}0.00000 E+00 \\
8.87354 E-01 \\
0.00000 E+00\end{array}$ & $4.46083 E+00$ & $9.30638 E-01$ & $4.68595 E-03$ \\
\hline $\begin{array}{c}94 \\
0.00000 E+00\end{array}$ & $\begin{array}{l}9.02889 E-01 \\
0.00000 E+00\end{array}$ & $4.50750 E+00$ & $9.30336 \mathrm{E}-01$ & $4.64454 E-03$ \\
\hline 95 & $8.46400 E-01$ & $4.55417 \mathrm{E}+00$ & $9.29433 E-01$ & $4.68214 \mathrm{E}-03$ \\
\hline $0.00000 \mathrm{E}+00$ & $0.00000 E+00$ & & & \\
\hline 96 & $8.87012 \mathrm{E}-01$ & $4.60000 E+00$ & $9.28982 \mathrm{E}-01$ & $4.65399 E-03$ \\
\hline $\begin{array}{c}0.00000 E+00 \\
97\end{array}$ & $0.00000 \mathrm{E}+00$ & & & \\
\hline $0.00000 E+00$ & $\begin{array}{l}9.70471 E-01 \\
0.00000 E+00\end{array}$ & $4.043050 T$ & $9.29419 E-01$ & $4.62541 E-03$ \\
\hline 98 & $8.69497 \mathrm{E}-01$ & $4.68783 \mathrm{E}+00$ & $9.28795 E-01$ & $4.61934 \mathrm{E}-03$ \\
\hline $0.00000 \mathrm{E}+00$ & $0.00000 E+00$ & & & \\
\hline 99 & 8. 90907E-01 & $4.73367 E+00$ & $9.28404 E-01$ & $4.58812 \mathrm{E}-03$ \\
\hline $\begin{array}{r}0.00000 E+00 \\
100\end{array}$ & $\begin{array}{l}0.00000 E+00 \\
9.86637 E-01\end{array}$ & $4.77750 E+00$ & $9.28998 E-01$ & \\
\hline $0.00000 \mathrm{E}+00$ & $0.00000 E+00$ & & & $4.57978 t-03$ \\
\hline 101 & $9.33507 E-01$ & $4.82067 E+00$ & $9.29044 \mathrm{E}-01$ & $4.53351 \mathrm{E}-03$ \\
\hline $0.00000 E+00$ & $0.00000 E+00$ & & & \\
\hline 102 & $1.00264 E+00$ & $4.86183 E+00$ & $9.29780 \mathrm{E}-01$ & $4.54789 E-03$ \\
\hline $0.00000 E+00$ & $0.00000 E+00$ & & & \\
\hline $0.00000 \mathrm{E}+00$ & $\begin{array}{l}1.04497 \varepsilon+00 \\
0.00000 E+00\end{array}$ & $4.90200 \mathrm{E}+00$ & $9.30920 \varepsilon-01$ & $4.64484 \mathrm{E}-03$ \\
\hline
\end{tabular}

KENO MESSAGE NUMBER K5-123 SPECIEIED NUMBER OE GENERATIONS. 
ANNULUS - $100 \mathrm{G} / \mathrm{L}$ 12FE H2O REFL

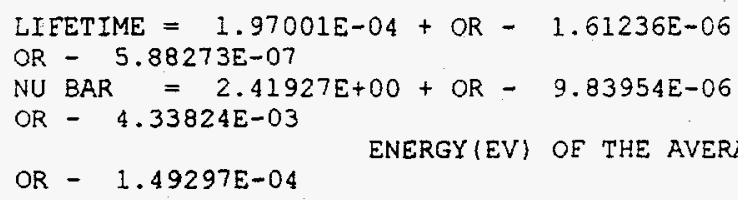

PROBLEM K12ELOO 18 CYLS IN A CUBOID

GENERATION TIME $=6.39673 E-05+$

AVERAGE EISSION GROUP $=2.44696 \mathrm{E}+01+$ LETHARGY CAUSING FISSION $=3.20547 \mathrm{E}-02+$
67 PER CENT

CONEIDENCE INTERVAI

0.92675 Tо 0.93608

0.92659 To 0.93601

0.92696 TO 0.93644

0.92767 To 0.93714

0.92794 To 0.93749

0.92697 To̊ 0.93639

0.92664 TO 0.93615

0.92654 Tо 0.93614

0.92615 TO 0.93583

0.92582 TO 0.93559

0.92764 To 0.93730

0.92670 то 0.93656

0.92747 TO 0.93736

0.92706 TO 0.93754

0.92409 To 0.93503

0.92557 To 0.93696

0.92502 Tо 0.93725

0.92502 Tо 0.93796

0.92585 To 0.93942
0.92480 TO 0.93982
95 PER CENT

CONEIDENCE INTERVAL
0.92188 TO 0.94072

0.92222 TO 0.94118

0.92293 To 0.94188

0.92316 T० 0.94227

0.92225 T० 0.94110

0.92189 TO 0.94090

0.92173 To 0.94095

0.92130 TO 0.94068

0.92093 TO 0.94048

0.92281 TO 0.94213

0.92177 To 0.94149

0.92252 TO 0.94230

0.92182 т० 0.94278

0.91862 Tо 0.94050

0.91988 TO 0.94266

0.91891 To 0.94336

0.91855 To 0.94443

0.91906 то 0.94621

0.91728 To 0.94733 


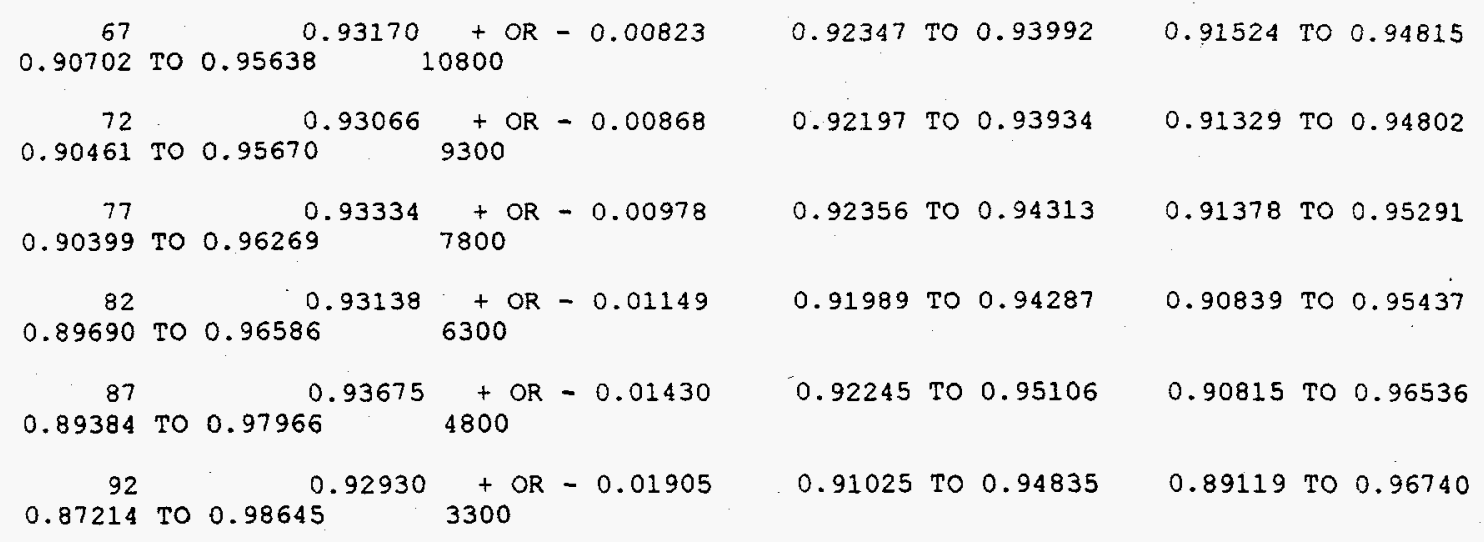


ANNULUS - $100 \mathrm{G} / \mathrm{L}$ 12FF H2O REFL

NO. OE INITIAL GENERATIONS

99 PER CENT SKIPPED

AVERAGE NUMBER OF K-EEEECTIVE CONEIDENCE INTERVAL HISTORIES

DEVIATION

$$
97 \quad 0.95469+O R-0.02784
$$

0.87118 TO 1.03820 1800
PROBLEM K12ELOO 18 CYLS IN A CUBOID
67 PER CENT

CONEIDENCE INTERVAL
0.92686 TO 0.98253
95 PER CENT

CONEIDENCE INTERVAL
0.89902 TO 1.01037 
REFL

PROBLEM K12ELOO 18 CYLS IN A CUBOID ANNULUS - $100 \mathrm{G} / \mathrm{L} 12 \mathrm{FE}$ H20

PLOT OE AVERAGE K-EFFECTIVE BY GENERATION RUN.

THE LINE REPRESENTS K-EEE $=0.9314+$ OR - 0.0047 WHICH OCCURS FOR 103 GENERATIONS RUN.

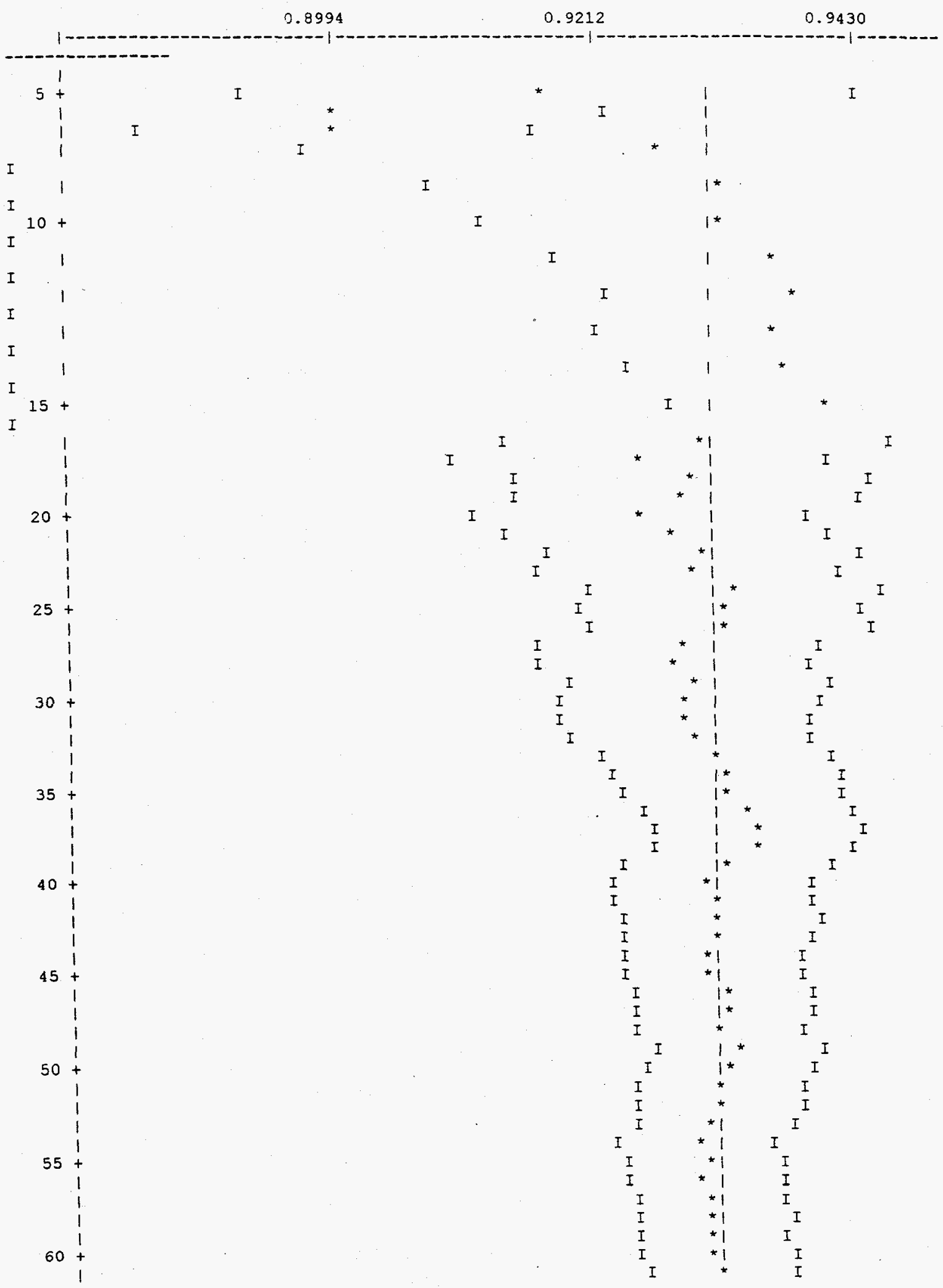




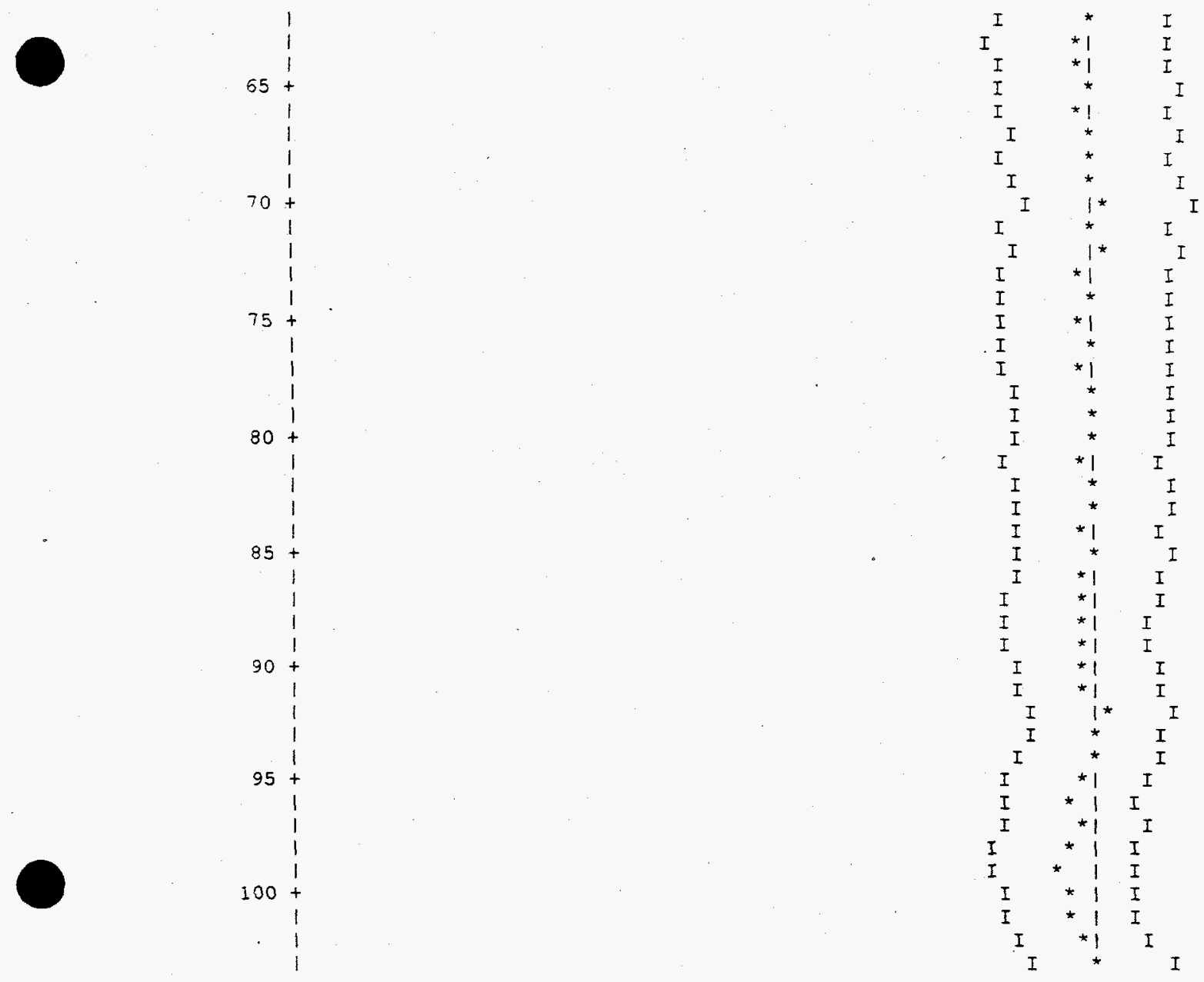


REEL

RROBLEM K12ELOO 18 CYLS IN. A CUBOID ANNULUS - $100 \mathrm{G} / \mathrm{L}$ 12EF H20

PLOT OE AVERAGE K-EEEECTIVE BY GENERATION SKIPPED.
THE LINE REPRESENTS K-EFF $=0.9314+$ OR -0.0047 WHICH OCCURS FOR SKIPPED.

3 GENERATIONS

0.9293

0.9765

1.0238

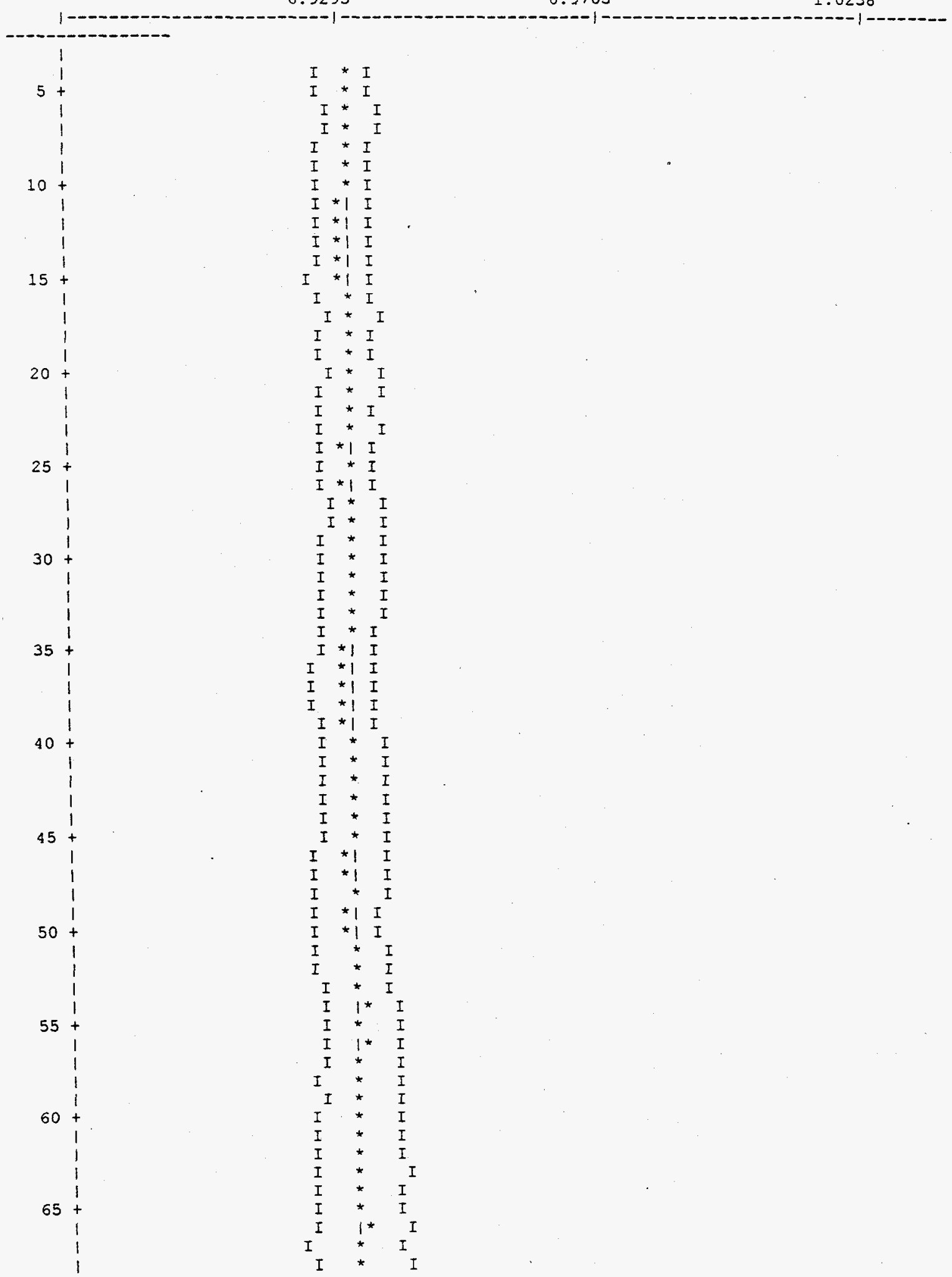


F-77
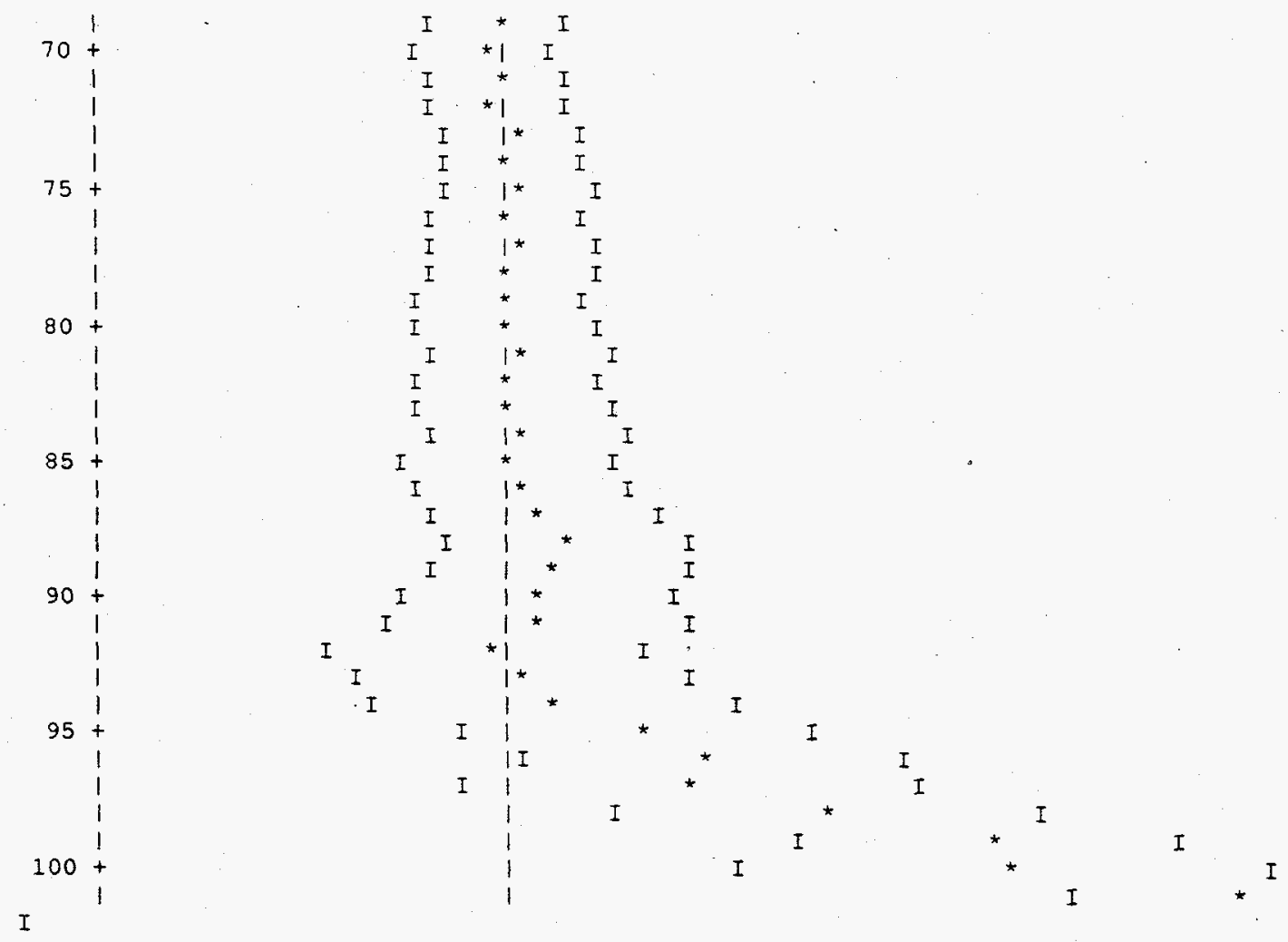
REFL

PROBLEM K12ELOO 18 CYLS IN A CUBOID ANNULUS - $100 \mathrm{G} / \mathrm{L}$ 12FE H2O

SKIPRING 3 GENERATIONS

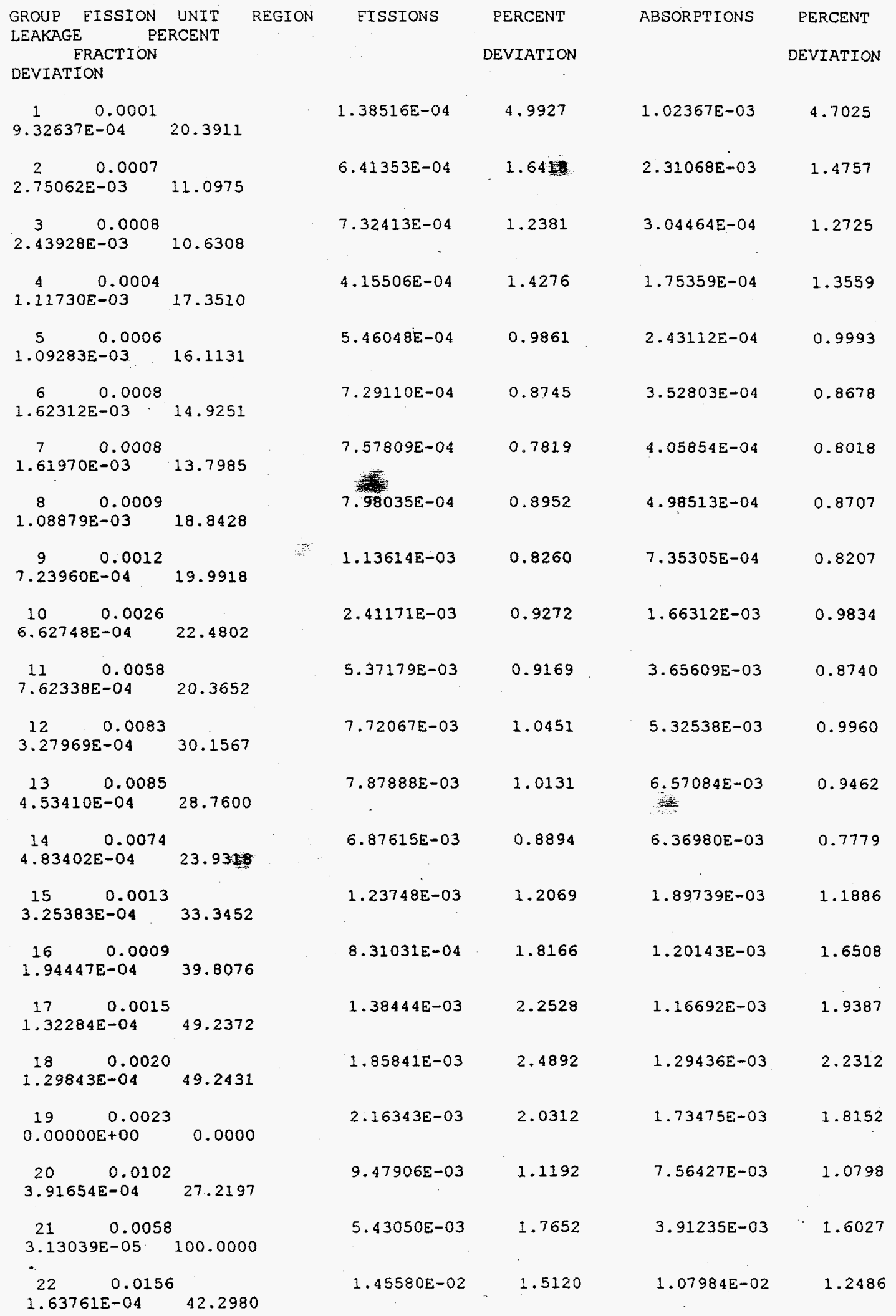




\section{F-79}

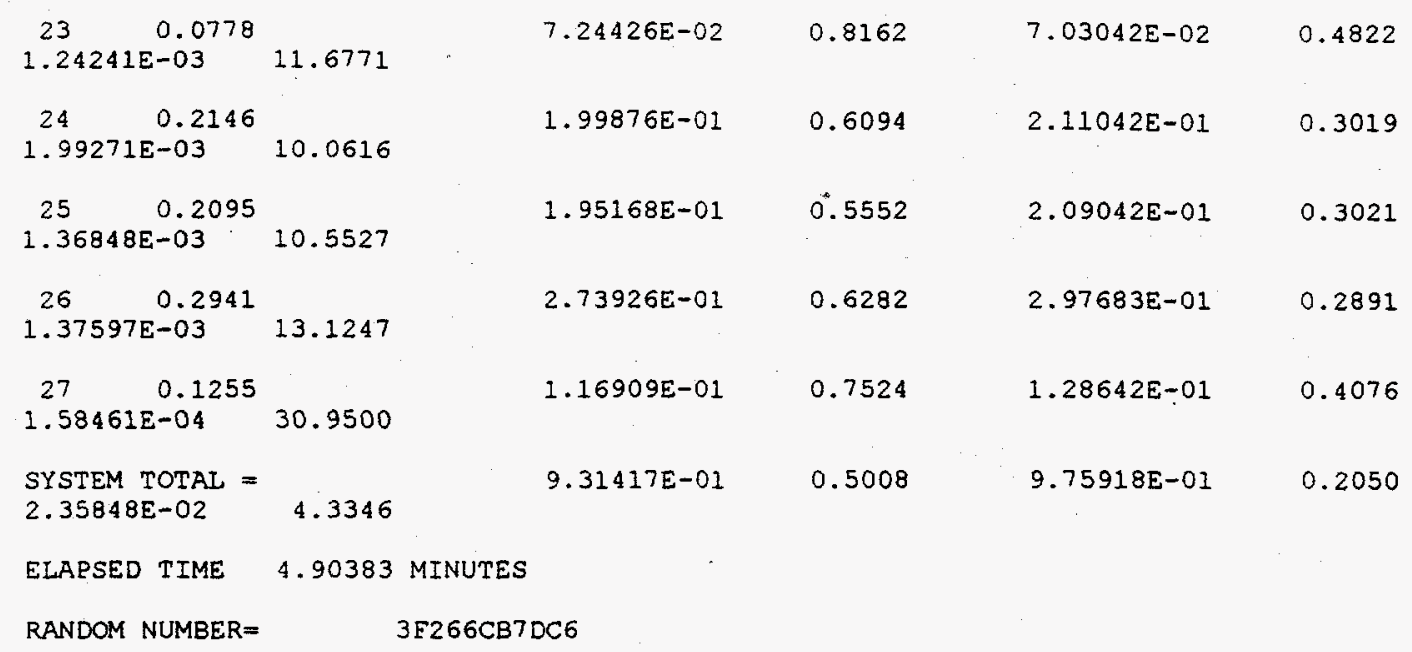


ANNULUS - $100 \mathrm{G} / \mathrm{L}$ 12FE H2O REFL

PROBLEM K12ELOO 18 CYLS IN A CUBOID

\begin{tabular}{|c|c|c|c|c|}
\hline UNIT & REGION & $\begin{array}{l}\text { EISSION } \\
\text { DENSITY }\end{array}$ & $\begin{array}{l}\text { PERCENT } \\
\text { DEVIATION }\end{array}$ & $\begin{array}{l}\text { TOTAL } \\
\text { EISSIONS }\end{array}$ \\
\hline 1 & $\begin{array}{l}1 \\
2 \\
3 \\
4\end{array}$ & $\begin{array}{l}3.742 E-08 \\
0.000 E+00 \\
0.000 E+00 \\
0.000 E+00\end{array}$ & $\begin{array}{r}96.08 \\
0.00 \\
0.00 \\
0.00\end{array}$ & $\begin{array}{l}3.983 E-05 \\
0.000 E+00 \\
0.000 E+00 \\
0.000 E+00\end{array}$ \\
\hline 2 & $\begin{array}{l}1 \\
2 \\
3 \\
4\end{array}$ & $\begin{array}{l}8.190 E-08 \\
0.000 E+00 \\
0.000 E+00 \\
0.000 E+00\end{array}$ & $\begin{array}{r}99.70 \\
0.00 \\
0.00 \\
0.00\end{array}$ & $\begin{array}{l}8.667 E-05 \\
0.000 E+00 \\
0.000 E+00 \\
0.000 E+00\end{array}$ \\
\hline 3 & $\begin{array}{l}1 . \\
2 \\
3 \\
4\end{array}$ & $\begin{array}{l}9.215 E-09 \\
0.000 E+00 \\
0.000 E+00 \\
0.000 E+00\end{array}$ & $\begin{array}{r}95.62 \\
0.00 \\
0.00 \\
0.00\end{array}$ & $\begin{array}{l}1.355 E-06 \\
0.000 E+00 \\
0.000 E+00 \\
0.000 E+00\end{array}$ \\
\hline 4 & $\begin{array}{l}1 \\
2 \\
3 \\
4\end{array}$ & $\begin{array}{l}1.369 \mathrm{E}-07 \\
0.000 \mathrm{E}+00 \\
0.000 \mathrm{E}+00 \\
0.000 \mathrm{E}+00\end{array}$ & $\begin{array}{r}57.51 \\
0.00 \\
0.00 \\
0.00\end{array}$ & $\begin{array}{l}3.159 E-05 \\
0.000 E+00 \\
0.000 E+00 \\
0.000 E+00\end{array}$ \\
\hline 5 & $\begin{array}{l}1 \\
2 \\
3 \\
4\end{array}$ & $\begin{array}{l}5.275 E-07 \\
0.000 E+00 \\
0.000 E+00 \\
0.000 E+00\end{array}$ & $\begin{array}{l}50.93 \\
0.00 \\
0.00 \\
0.00\end{array}$ & $\begin{array}{l}1.766 \mathrm{E}-04 \\
0.000 \mathrm{E}+00 \\
0.000 \mathrm{E}+00 \\
0.000 \mathrm{E}+00\end{array}$ \\
\hline 6 & $\begin{array}{l}1 \\
2 \\
3 \\
4\end{array}$ & $\begin{array}{l}3.681 E-07 \\
0.000 E+00 \\
0.000 E+00 \\
0.000 E+00\end{array}$ & $\begin{array}{l}43.06 \\
0.00 \\
0.00 \\
0.00\end{array}$ & $\begin{array}{l}1.683 E-04 \\
0.000 E+00 \\
0.000 E+00 \\
0.000 E+00\end{array}$ \\
\hline 7 & $\begin{array}{l}1 \\
2 \\
3 \\
4\end{array}$ & $\begin{array}{l}1.500 E-05 \\
0.000 E+00 \\
0.000 E+00 \\
0.000 E+00\end{array}$ & $\begin{array}{l}2.99 \\
0.00 \\
0.00 \\
0.00\end{array}$ & $\begin{array}{l}7.326 \mathrm{E}-02 \\
0.000 \mathrm{E}+00 \\
0.000 \mathrm{E}+00 \\
0.000 \mathrm{E}+00\end{array}$ \\
\hline 8 & $\begin{array}{l}1 \\
2 \\
3 \\
4\end{array}$ & $\begin{array}{l}6.963 E-05 \\
0.000 E+00 \\
0.000 E+00 \\
0.000 E+00\end{array}$ & $\begin{array}{l}3.76 \\
0.00 \\
0.00 \\
0.00\end{array}$ & $\begin{array}{l}2.436 \mathrm{E}-02 \\
0.000 \mathrm{E}+00 \\
0.000 \mathrm{E}+00 \\
0.000 \mathrm{E}+00\end{array}$ \\
\hline 9 & $\begin{array}{l}1 \\
2 \\
3 \\
4\end{array}$ & $\begin{array}{l}7.448 E-05 \\
0.000 E+00 \\
0.000 E+00 \\
0.000 E+00\end{array}$ & $\begin{array}{l}3.07 \\
0.00 \\
0.00 \\
0.00\end{array}$ & $\begin{array}{l}3.791 E-02 \\
0.000 E+00 \\
0.000 E+00 \\
0.000 E+00\end{array}$ \\
\hline 10 & $\begin{array}{l}1 \\
2 \\
3 \\
4\end{array}$ & $\begin{array}{l}7.966 \mathrm{E}-05 \\
0.000 \mathrm{E}+00 \\
0.000 \mathrm{E}+00 \\
0.000 \mathrm{E}+00\end{array}$ & $\begin{array}{l}2.20 \\
0.00 \\
0.00 \\
0.00\end{array}$ & $\begin{array}{l}9.139 E-02 \\
0.000 E+00 \\
0.000 E+00 \\
0.000 E+00\end{array}$ \\
\hline 11 & $\begin{array}{l}1 \\
2 \\
3 \\
4\end{array}$ & $\begin{array}{l}9.250 E-05 \\
0.000 E+00 \\
0.000 E+00 \\
0.000 E+00\end{array}$ & $\begin{array}{l}2.01 \\
0.00 \\
0.00 \\
0.00\end{array}$ & $\begin{array}{l}1.158 \mathrm{E}-01 \\
0.000 \mathrm{E}+00 \\
0.000 \mathrm{E}+00 \\
0.000 \mathrm{E}+00\end{array}$ \\
\hline 12 & $\begin{array}{l}1 \\
2 \\
3 \\
4\end{array}$ & $\begin{array}{l}9.454 E-05 \\
0.000 E+00 \\
0.000 E+00 \\
0.000 E+00\end{array}$ & $\begin{array}{l}1.71 \\
0.00 \\
0.00 \\
0.00\end{array}$ & $\begin{array}{l}1.287 E-01 \\
0.000 E+00 \\
0.000 E+00 \\
0.000 E+00\end{array}$ \\
\hline 13 & $\begin{array}{l}1 \\
2 \\
3 \\
4\end{array}$ & $\begin{array}{l}9.038 E-05 \\
0.000 E+00 \\
0.000 E+00 \\
0.000 E+00\end{array}$ & $\begin{array}{l}1.73 \\
0.00 \\
0.00 \\
0.00\end{array}$ & $\begin{array}{l}1.333 E-01 \\
0.000 E+00 \\
0.000 E+00 \\
0.000 E+00\end{array}$ \\
\hline 14 & $\begin{array}{l}1 \\
2\end{array}$ & $\begin{array}{l}8.233 \mathrm{E}-05 \\
0.000 \mathrm{E}+00\end{array}$ & $\begin{array}{l}1.71 \\
0.00\end{array}$ & $\begin{array}{l}1.180 E-01 \\
0.000 E+00\end{array}$ \\
\hline
\end{tabular}


F-81

$\begin{array}{ccccc} & 3 & 0.000 E+00 & 0.00 & 0.000 E+00 \\ & 4 & 0.00 E E+00 & 0.00 & 0.000 E+00 \\ 15 & 1 & 7.945 E-05 & 3.14 & 2.505 E-02 \\ & 2 & 0.000 E+00 & 0.00 & 0.000 E+00 \\ & 3 & 0.00 E E+00 & 0.00 & 0.000 E+00 \\ & 4 & 0.000 E+00 & 0.00 & 0.000 E+00 \\ & & & \\ 16 & 1 & 7.252 E-06 & 4.78 & 4.150 E-03 \\ & 2 & 5.586 E-05 & 2.37 & 9.590 E-02 \\ & 3 & 0.000 E+00 & 0.00 & 0.000 E+00 \\ & 4 & 0.000 E+00 & 0.00 & 0.000 E+00 \\ & 5 & 0.000 E+00 & 0.00 & 0.000 E+00 \\ & 6 & 0.000 E+00 & 0.00 & 0.000 E+00 \\ 17 & & & & \\ & 1 & 4.401 E-06 & 6.36 & 1.645 E-03 \\ & 2 & 2.929 E-05 & 3.04 & 6.168 E-02 \\ & 3 & 0.000 E+00 & 0.00 & 0.000 E+00 \\ & 4 & 0.000 E+00 & 0.00 & 0.000 E+00 \\ & 5 & 0.000 E+00 & 0.00 & 0.000 E+00 \\ 18 & 1 & 1.768 E-05 & 5.49 & 1.991 E-02 \\ & 2 & 0.000 E+00 & 0.00 & 0.000 E+00 \\ & 3 & 0.000 E+00 & 0.00 & 0.000 E+00 \\ & 4 & 0.000 E+00 & 0.00 & 0.000 E+00\end{array}$

GLOBAL UNIT 
F-82

PROBLEM K12ELOO 18 CYLS IN A CUBOID ANNULUS - $100 \mathrm{G} / \mathrm{L} 12$ EE H2O REEL

0.7813 TO 0.8044

0.8044 TO 0.8275

0.8275 TO 0.8506

0.8506 TO 0.8737

0.8737 TO 0.8968

0.8968 TO 0.9199

0.9199 TO 0.9430

0.9430 TO 0.9661

0.9661 TO 0.9892

0.9892 TO 1.0123

1.0123 TO 1.0354

1.0354 TO 1.0584

0.7813 TO 0.8044

0.8044 TO 0.8275

0.8275 TO 0.8506

0.8506 TO 0.8737

0.8737 TO 0.8968

0.8968 TO 0.9199

0.9199 TO 0.9430

0.9430 T0 0.9661

0.9661 TO 0.9892

0.9892 TO 1.0123

1.0123 TO 1.0354

1.0354 TO 1.0584

0.7813 TO 0.8044

0.8044 TO 0.8275

0.8275 TO 0.8506

0.8506 TO 0.8737

0.8737 To 0.8968

0.8968 TO 0.9199

0.9199 TO 0.9430

0.9430 TO 0.9661

0.9661 TO 0.9892

0.9892 TO 1.0123

1.0123 TO 1.0354

1.0354 TO 1.0584

0.7813 TO 0.8044

0.8044 TO 0.8275

0.8275 TO 0.8506

0.8506 TO 0.8737

0.8737 TO 0.8968

0.8968 TO 0.9199

0.9199 To 0.9430

0.9430 TO 0.9661

0.9661 TO 0.9892

0.9892 TO 1.0123

1.0123 TO 1.0354

1.0354 TO 1.0584
EREQUENCY FOR GENERATIONS 4 TO 103

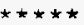

$\star * * * *$

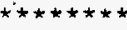

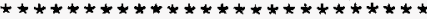

$\star \star \star \star \star * * * * *$

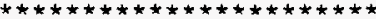

$\star * \star * * * * * * * * * * * * * * *$

$\star \star \star \star \star * \star * *$

*

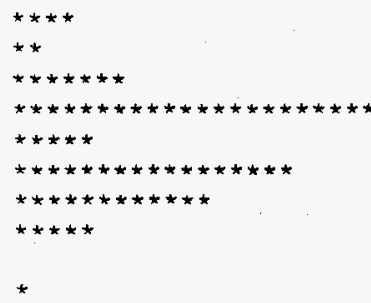

EREQUENCY FOR GENERATIONS 54 TO 103

$\star \star \star$

$\star \star$

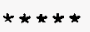

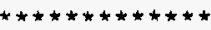

$\star \star \star \star$

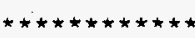

$\star \star \star \star \star \star \star \star * *$

$\star \star \star \star *$

$\star$

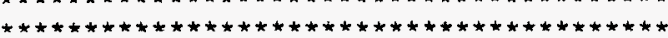

CONGRATUIATIONS! YOU HAVE SUCCESSFULIY TRAVERSED THE PERILOUS PATH THROUGH KENO $V$ IN 4.90483 MINUTES

$\square$ 


\section{DISTRIBUTION}

1. L. V. Asplund

2. K. R. Elam

3. M. J. Haire

4. J. C. Ingram, III

5-7. L. J. Jollay (3)

8. W. C. Jordan

9. P. T. Owen

10. L. B. Raulston

11. J. T. Shor

12. J. V. Spence

13. Central Research Library

14. Document Reference Section

15. DRP File Room

16. File-EMEF DMC-RC

17. K-25 Health \& Safety Document Center

18. Laboratory Records

19. Portsmouth Laboratory Records

20-21. Office of Scientific and Technical Information, P.O. Box 62, Oak Ridge, TN 37831 (2) 